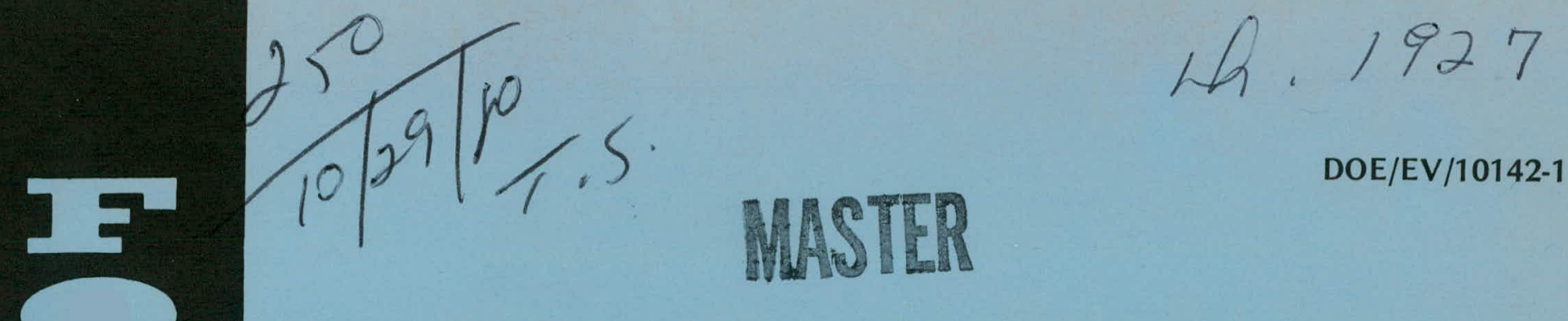

\title{
BENEFIT-COST FRAMEWORK FOR ANALYSIS OF TRACE ELEMENT EMISSIONS FROM COAL-FIRED POWER PLANTS
}

November 1979

Work Performed Under Contract No. AC02-79EV10142

Resources for the Future

Washington, D. C.

\section{U. S. DEPARTMENT OF ENERGY}




\section{DISCLAIMER}

This report was prepared as an account of work sponsored by an agency of the United States Government. Neither the United States Government nor any agency Thereof, nor any of their employees, makes any warranty, express or implied, or assumes any legal liability or responsibility for the accuracy, completeness, or usefulness of any information, apparatus, product, or process disclosed, or represents that its use would not infringe privately owned rights. Reference herein to any specific commercial product, process, or service by trade name, trademark, manufacturer, or otherwise does not necessarily constitute or imply its endorsement, recommendation, or favoring by the United States Government or any agency thereof. The views and opinions of authors expressed herein do not necessarily state or reflect those of the United States Government or any agency thereof. 


\section{DISCLAIMER}

Portions of this document may be illegible in electronic image products. Images are produced from the best available original document. 


\section{DISCLAIMER}

"This book was prepared as an account of work sponsored by an agency of the United States Government. Neither the United States Government nor any agency thereof, nor any of their employees, makes any warranty, express or implied, or assumes any legal liability or responsibility for the accuracy, completeness, or usefulness of any information, apparatus, product, or process disclosed, or represents that its use would not infringe privately owned rights. Reference herein to any specific commercial product, process, or service by trade name, trademark, manufacturer, or otherwise, does not necessarily constitute or imply its endorsement, recommendation, or favoring by the United States Government or any agency thereof. The views and opinions of authors expressed herein do not necessarily state or reflect those of the United States Government or any agency thereof."

This report has been reproduced directly from the best available copy.

Available from the National Technical Information Service, U. S. Department of Commerce, Springfield, Virginia 22161.

Price: Paper Copy $\$ 15.00$

Microfiche $\$ 3.50$ 
Shaut Ben-David (University of New Mexico) Gilbert Bonem (University of New Mexico) Allen Kneese (Resources for the Future) William Schulze (University of Wyoming) Dolores Willett (University of New Mexico) Michael Williams (John Muir Institute). 
THIS PAGE

\title{
WAS INTENTIONALLY
}

\author{
LEFT BLANK
}


Table of Conterits

Page

Chapter 1 Introduction ............. 1-1 Notes and References for Chapter 1..... 1-7

Chapter 2 Atmospheric Emissions and Dispersion Patterns of Trace Elements from Southwestern Coal-Fired Power Plants . . . . . . . . . . 2-1

A. Emissions of Trace Elements from Southwestern Coal-Fired Power Plants ........ 2-1

B. Atmospheric Dispersion and Deposition of Trace Elenents. . . . . . . . . .

1. Qualitasive Description of the Transportation and Transformation of Pollutants. . .

2. Releyant Characteristics of the Southwest

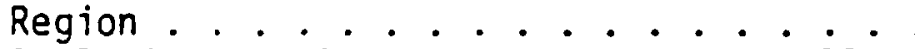

3. Analytical Tools for Prediction of Pollutant Removal and Dispersal ...... 2-23 K-Theory ........... 2- 2-26

4. Estimation Technique ..... . 2-27

5. Historical Perspective on Deposition Problems ............ 2-29

6. Conclusions........... 2-33 Appendix A to Chapter 2 - Energy Resource Development Scenarios for the Four Corners Region . . 2-35 Notes and References for Chapter 2.... 2-55

Chapter 3 Disposal of Waste Ash. . . . . . . . . . 3-1 Methods for Reducing Environmental Impact SolidLiquid Wastes............. 3-22

(a) Landfills............ . . 3-23

(b) Lining of Ponds. .......... 3-24

(c) Other Control Techniques . . . . . 3-26

Costs of Reducing Impacts of Solid-Liquid Wastes 3-27

(a) Landfills. . . . . . . . . . . 3- 3-27

(b) Liners . . . . . . . . . . . 3-29

(c) Materials Reccvery ........... 3-31

(d) Conclusions. .............. 3-31

Some Calculations on Trace Elements Effects. . 3-32

Bad Case I Assumptions . . . . . . . 3-32

Bad Case II Assumpations ....... . 3-33

Conclusions. . . . . . . . . . 3-35

Notes and References to Chapter 3..... 3-37

Chapter 4 Effects of Trace Elements on Plants, Humans and Animals............... 4-1

Trace Element Deposition from a Coal-Fired Power

Plant in the Southwest......... 4-5

Impact of Trace Element Emissions on Vegetation. 4-11

Toxicity Versus Essentiality of Selected Trace. 4-15 
Appendix A to Chapter 4. . . . . . . . 4-22

Appendix B to Chapter 4. ......... 4-39

Notes and References to Chapter 4. . . . . 4-76

Chapter 5 Economic Measures of Damages . . . . . . . . 5-1

Valuing Human Health Effects........ 5-2

a) Mortality - Valuing Safety. . . . . . 5-2

b) Valuing Morbidity ........ 5-7

c) The Ethics of Valuing Health Effects. . . 5-10

Valuing Ecosystem Effects......... 5-13

a) Recreation Damages......... 5-13

b) Broader Ecosystem Effects ....... 5-16

Calculating the Benefits of Trace Element

Control.............. 5-19

a) Discounting............ 5-19

b) Aggregation ........... 5-20

c) Economic Analys is in an Uncertain World . . 5-20

Notes and References for Chapter 5.... . 5-23

Chapter 6 Federal Legislation and Regulations Affecting

Trace Element Emissions.......... b-

The Clean Air Act. . . . . . . . . . . . 6-1

The Federal Water Pollution Control Act. . . . 6-6

Resource Conservation and Recovery Act (RCRA). . 6-8

Other Legislation. . . . . . . . . . 6-10

Conclusions. . . . . . . . . . . . 6-12

Notes and References for Chapter 6..... 6-13

Chapter 7 Conclusions............. 7-1

Notes and References ......... 7-11 


\section{Chapter 1}

\section{Introduction}

The possibility of performing a benefit-cost analysis of hazardous material emissions from coal-fired power plants is the subject of this report. From one viewpoint almost any material emitted to the environment may be "hazardous." But "hazardous material" as the term is used here refers to substances which are particularly toxic and which tend to pose a persistent and long-lived threat to the environment and to human beings. Disposal of wastes that contain arsenic to sanitary landfills is a case in point. This material might not present a hazard for some time; but slow leaching of arsenic and arsenic compounds into the water table might eventualiy contaminate water supplies. Similarly, a slowly increasing level of mercury in soils around a power plant might eventually poison the food supplies of area wildlife or of human beings.

A variety of hazardous materials, in the sense identified above, are emitted from coal-fired powcr.plants:

-- Trace elements, including mercury, arsenic, beryllium, selenium, etc. are emitted to the atmosphere and are components of aqueoussolid wastes disposed to ash ponds or landfills. "Trace elements" refer to all of the inorganic elements except for the eight abundant rock-forming elements (oxygen, silicon, aluminum, iron, calcium, sodium, potassium, and magnesium).

-- Emissions of sulfur oxides to the atmosphere may result in the formation of sulfates and other sulfur compounds. Many of these have persistent effects including acid rains and formation of 
a tmospheric haze.

-- Particulate polycyclic organic matter (PPOM) is likely to be emitted to the atmosphere. Sawyer [1] quotes an EPA publication [2] on the nature of PPOM:

"Currently, two classes of polycyclic organic compounds are proven carcinogens in experimental animals, albeit not by the inhalation route. The two -- the polycyclic aromatic hydrocarbons and their nitrngen analogs, the aza arenes -- are present in the particulate phase in polluted air. Occupational exposure to mixtures containing these compounds has led to well documented cases of lung cancer."

Undoubtedly, a number of other materials emitted from coal-fired power plants are also hazardous (e.g., transformation products of nitrogen oxides). 'In this report emphasis will be on environmental emissions of trace elements. The decision to focus on trace elements was largely a matter of convenience. Time and budget constraints seemed to preclude consideration of all hazardous materials; and the impact of trace element emissions seemed to be important but subject to considerable doubt and uncertainty. It thus seemed natural to emphasize this category of hazardous materials.

Another omission in this report is that many processes related to the conversion of coal to electricity were omitted. The total conversion process includes coal mining, perhaps coal preparation and beneficiation; low btu coal gasification and solvent refining are other processes that might be considered. All of these processes may involve environmental emissions of trace elements. For example, overburden from coal mines may be subjected to winds, and.windb'own trace elements may enter the atmosphere (there has been some discussion of boron becoming airborne in this manner). Coal preparation plants produce 
large amounts of aqueous-solid wastes that might pose a threat of trace element leaching to groundwater. Despite the fact that there are trace element emissions from a 11 processes in coal conversion technology, we have focused on emissions from power plants. Emphasis on power plants was largely a matter of time and budget constraints. What information would be required for a benefit-cost analysis of trace elements from coal-fired power piants? Trace elements from coal-fired plants enter the environment mainly through atmospheric emissions and from disposal of waste ash to ponds and landfills. Trace elements emitted to the atmosphere might cause economic damage by adversely affecting human health or area wildlife and recreational values; and these adverse human and wildi ife health effects can occur ei.ther through inhalation or ingestion of trace elements. Thus, it is necessary to know the rate at which trace elements are emitted to the atmosphere; theirdispersion through the atmosphere and their rates of deposition on soil and plants; the amounts of trace elements that are ultimately inhaled and ingested by humans and wildlife, as dependent on patterns of atmospheric dispersion and soil deposition; and the response of humans and wildlife to these "doses" of trace elements (e.g., at what exposure rate for what period of time will humans develop iliness or death from, say, lead or zinc).

The requirements for a benefit-cost analys is of trace element impact from disposal of aqueous-solid wastes to ponds and landfills involve knowledge of the amounts of trace elements in those wastes; the extent to which these elements (and their compounds) are leached to groundwater or flushed as pond effluent to streams and rivers; 
the extent to which humans and wildlife use these groundwater and/or surface water supplies; the extent of soil and plant uptake of trace elements from a contaminated soil-groundwater complex; and, finally the response of human and wildiife health to doses of trace elements in contaminated water and in contaminated plants.

Given some knowledge of these relationships, a benefit-cost analysis could be completed if there were also knowledge of abatement alternatives. These "alternatives" include use of advanced chemical waste landfills for reduction of trace element leaching to groundwater, pond liners (perhaps using synthetic lining material) for the same purpose, and use of waste materials for by-products rather than for disposal to ponds or landfills. Alternatives for reduction of trace element atmospheric emissions include the use of electrostatic precipitators (a common practice at most coal-fired power plants in the U.S.), limestone scrubbers (these help to control trace elements that are in gaseous state), and fine particle scrubbing.

For convenience, we may label the alternatives for changing pondlandfill emissions as $x_{1}, x_{2}, x_{3}, \cdots, x_{n}$, and the alternatives for altering atmospheric emissions might be labeled $\gamma_{1}, Y_{2}, \cdots, \gamma_{m}[3]$. Now suppose that one of the abatement alternatives is installed (suppose, for example, that 20 acres of advanced chemical waste landfill are installed). This alternative will carry with it a certain economic cost, $c_{\eta}$. On the other hand, certain economic benefits are likely to be generated. In the case of an advanced chemical waste landfill, we would take the knowledge of amounts of trace elements in disposed wastes leaching rates, groundwater - soil interaction 
relationships, etc. (i.e., all the knowledge of relationships previously mentioned); and the ultimate impacts on human and wildlife health with and without the chemical waste landfill would then be compared. When an economic value is placed on these health effects, a number representing economic benefits, $B_{1}$, is obtained. This number refers to the economic value of health improvements with the abatement alternative as compared to the situation without the alternative. Net economic benefits, if any, are the excess of benefits over costs, $B_{1}-C_{l}$.

The preceding paragraphs are a schematic of a methodology for performing a benefit-cost analysis of trace element emissions from coal-fired power plants. It is clear that the knowledge required is very extensive, and in this report we only attempt to discuss whether such an analysis is possible. In the chapters that follow, it will become apparent that some information (rates of trace element atmospheric emissions, initial patterns of atmospheric dispersion) is accessible while other information (leaching rates, possible groundwater-surface water interconnections) is in a quite primitive state.

As a final note about the benefit-cost schematic, it is relevant to mention, once again, that an important characteristic of trace elements is the persistent and Tengthy threat that they pose to the environment. Whether placing power plant wastes in advanced chemical landfills rather than in ponds will reduce the environmental hazard of trace elements is, as yet, an open question. Indeed. with reference to the persistence of the problem, one might argue that the oniy. impact of installing a landfill is to twist the time horizon of the environmental 
threat. That is, the immediate hazards from ponding of the wastes (a hazard with a life of, say, the next 20 years) is transfomed to a long-term hazard, perhaps 80-100 years away, after the advanced landfill has been subjected to considerable weathering, deterioration, and even neglect. It is important to realize that a meaningful benefitcost analysis of trace elements must deal with a lengthy time horizon and with the possibility that some "abatement" alternatives may have only the effect of postponing environmental damage.

Discussion of the feasibility of performing benefit-cost analysis of trace element impacts is divided into five major chapters. The next chapter deals with atmospheric emissions of trace elements and their dispersion. After that, trace elements in disposed power plant ash are discussed, including some analys is of leaching rates and soil transportation of trace elements. Impacts of trace elements on humans, animals, and plants are discussed in Chapter 4 of the report. In Chapter 5 , methodology for placing economic values on damages to human health is discussed. Chapter 6 contains a discussion of federal legislation and regulations concerning trace element emissions from coal-fired power plants. Taken together, these chapters attempt to define the exact way that benefits and costs might be traced, that is, the report attempts to specify an adequate benefit-cost framework. In the final chapter, some tentative conclusions about power plant trace element emissions are set forth. 
Notes and References for Chapter 1

[1] Sawyer, J. W., Jr.; Harrington, W.; Abbey, D., The Electric Power and Synthetic Fuels Industries in the Southwest, report prepared by Resources for the Future, Inc. August 1977.

[2] U. S. Environmental Protection Agency, Scientific and Technical Assessment Report on Particulate Polycyclic Organic Matter, distributed by National Technical Information Service, Springfield, VA, PB-241-790, March 1975.

[3] The technical reader will note that use of this notation implies that the alternative abatement techniques can be operated at different levels. That is, $x_{1}$ actually refers not simply to the first abatement alternative (say, use of advanced chemical waste landfill) but to the level of this activity (say, the number of acres of advanced chemical waste landfill installed). 


\section{Chapter 2}

Atmospheric Emissions and Dispersion Patterns of

Trace Elements from Southwestern Coal-Fired Power Plants

In this section, two topics involving atmospheric dispersion of trace elements are discussed. First, estimates are made of trace element emissions from coal-fired power plants and preliminary projections of future emissions are calculated. Second, a framework for estimating the atmospheric dispersion of trace elements is developed, and a calculation of probable soil deposition rates is made. Major emphas is is on developing a framework for analysis, but the calculations made here will probably also prove interesting. They provide some basis for making tentative statements about the significance of trace element emissions in the Southwest.

The chapter is divided into two sections; the first section discusses emission rates and the second section develops models and calculations of dispersion and deposition.

\section{A. Emissions of Trace Elements from Southwestern Coal-Fired Power Plants}

In this section, estimates are made of present and future emissions of trace elements from southwestern power plants. The first step in this process was to obtain estimates of trace element emissions at a number of power plants in the western U.S. and, from these, to devise emission coefficients as, e.g., kilograms per $1000 \mathrm{MWH}$ generated. The second step was to obtain estimates and projections or the amount of coalfired electrical capacity in the Southwest. Multiplication of the emission 
coefficients by total electricity generation from coal-fired plants yields estimates of total trace element emissions.

Table 1 indicates emissions of trace elements at a number of coal-fired power plants. These estimates were found in the engineering literature, and a few comments about them are relevant:

1. The data for Kaiparowits refer to the proposed 3000 Mw station in southern Utah, a proposal that has been abandoned. Data for both Kaiparowits and the Nayajo Generating Station are taken from a study done by Eric Walther for the Lake Powell Research Study [1]. It was assumed that Kaiparowits would have an electrostatic precipitator. (ESP) with average efficiency of $99.5 \%$ (this efficiency does not apply to specific metals but only to total fly ash). The Navajo Generating Station has an ESP with average efficlency of $99 \%$.

2. The data for the Four lorners Generating Station were taken from a study by Roffman, Kary, Hodgins [2]. The data refer to Units 4 and 5 of the Four Corners station; those units have an ESP with. efficienty $>95 \%$.

3. The data for Radian Stations 1,2, and 3 are taken from a study performed by Radian Corporation for the Denver office OF EPA [3]. All thiree stations operate on Wyoming or North Dakota coals. Station 1 operates with Venturi scrubbers having average particulate collection efficiency of $99 \%$. Station. 2 operates with an electrostatic precipitator having efficiency of $99 \%$. Station 3 operates with a cyclone having efficiency of $50 \%$. 
4. The data for the Tennessee station are taken from a study by Klein that appeared in Environmental Science and Technology [4].

The Tennessee plant operates with electrostatic precipitators having average efficiency of $99 \%$.

For four of the stations listed in Table 1, escape fractions (i.e., proportion of the element in incoming coal that goes into the atmosphere) are also listed. Table 1 does not include all engicering estimates of trace element emissions from power plants that have been made in the last ten years. Rather, it includes estimates that are most rilevant to the Southwest. A recent article by Ondov, Ragaini, and Bierman in Environmental Science and Technology [5] has an extensive list of articles and reports containing estimates of trace element emissions.

The last column of Table 1 contains our estimates of average trace element emissions at Southwestern coal-fired power plants. The main assumption underlying these estimates is that in the future all Southwestern coal-fired power plants will operate with electrostatic precipitators of efficiency $95 \%$ or more (or with similarly efficient control equipment). An important note concerns the assumptions made about future $\mathrm{SO}_{2}$ scrubbing. $\mathrm{SO}_{2}$ control equipment, such as limestone scrubbing will significantly affect emissions of certain trace elements especially mercury, selenium and arsenic. The latter frequently volatilize into gaseous state in the combustion chamber and will partially escape electrostatic precipitators. However, these elements in gaseous state will frequently be partially captured by limestone scrubbers. Consequently, stack emissions of some elements depenas on whether limestone scrubbing is used. For the preliminary and tentative projections 
Table I

Endssion Rates of Irace Metals at Cosl-fired Power Plants (onte are tg/todo imt generated)

\begin{tabular}{|c|c|c|c|c|c|c|c|c|c|c|c|c|c|}
\hline & \multicolumn{2}{|c|}{$\begin{array}{l}\text { xotparowits } \\
\text { (as proposed) }\end{array}$} & \multicolumn{2}{|c|}{$\begin{array}{l}\text { Mavajo Gene-ot ing } \\
\text { Stat lo: }\end{array}$} & \multicolumn{2}{|c|}{$\begin{array}{l}\text { Radlon Statlen'to. I } \\
\text { (Hyoulag coal) }\end{array}$} & \multicolumn{2}{|c|}{$\begin{array}{l}\text { Radian stollon Mo. } 2 \\
\text { (Myoumlog cool) }\end{array}$} & \multicolumn{2}{|c|}{$\begin{array}{l}\text { Radlan statlan io }{ }^{3} \\
\text { (Horth Dokota (Ignite) }\end{array}$} & \multirow{2}{*}{$\begin{array}{l}\text { Ienuessee } \\
\text { Stallon } \\
\text { Entssion } \\
\text { Rate }\end{array}$} & \multirow{2}{*}{$\begin{array}{l}\text { Four Corners } \\
\text { Generating Stotion } \\
\text { Emission } \\
\text { Rote }\end{array}$} & \multirow{2}{*}{$\begin{array}{c}\text { Sugges ted } \\
\text { Value for } \\
\text { Southwest } \\
\text { Hodel }\end{array}$} \\
\hline & $\begin{array}{l}\text { Entsslon } \\
\text { Rale }\end{array}$ & $\begin{array}{l}\text { Escape } \\
\text { iractlon }\end{array}$ & $\begin{array}{l}\text { Cmisston } \\
\text { Rete }\end{array}$ & $\begin{array}{c}\text { Escapo } \\
\text { Iraction }\end{array}$ & $\begin{array}{l}\text { Enlssion } \\
\text { Rule }\end{array}$ & $\begin{array}{l}\text { Escape } \\
\text { Frection }\end{array}$ & $\begin{array}{l}\text { Enlssion } \\
\text { Rete }\end{array}$ & $\begin{array}{l}\text { Escape } \\
\text { fraction }\end{array}$ & $\begin{array}{l}\text { Enission } \\
\text { Rate }\end{array}$ & $\begin{array}{l}\text { Escape } \\
\text { Irrection }\end{array}$ & & & \\
\hline fluor Ine & 1.81 & .076 & 3.0 & .076 & 1.55 & .020 & 2.58 & .016 & 29.9 & .340 & a/ø & .19 & 2.0 \\
\hline Manganese & $.010-.091$ & $.004-.034$ & $.03-.20$ & $004-.034$ & .10 & .004 & .11 & .012 & 5.7 & .125 & .22 & .11 & .20 \\
\hline Uranilua & .0014 & .015 & $.00065-.02$ & .015 & .04 & .020 & .0029 & .015 & .12 & .216 & .0056 & $n / a$ & .005 \\
\hline Vllonlim & $.46-1.42$ & $.005-.022$ & $.67-2.60$ & $.005-.022$ & 1.44 &.$\infty 03$ & 2.06 & .006 & 16.0 & .679 & 1.65 & $n / a$ & 1.5 \\
\hline Chromilum & $.0018-.018$ & $.001-.012$ & $.029-.290$ & $.001-.012$ & 1.38 & .099 & .55 & .124 & 3.49 & .103 & $\cdot .083$ & .011 & .3 \\
\hline$Z$ Inc & .01 & $.026-.072$ & $.055-.013$ & $.026-.012$ & .48 & .025 & .079 & .026 & 2.86 & .521 & .55 & .0056 & .4 \\
\hline Lead & .0051 & $.028-.011$ & $.04-.120$ & $028-.017$ & .091 & .019 & .051 & .075 & .30 & .646 & .055 & .021 & .1 \\
\hline Arsenic & $.00019-.00057$ & $.005-.150$ & $.0001-.034$ & $005-.150$ & .038 & .015 & .00069 & .005 & 1.06 & .205 & .055 & .016 & .03 \\
\hline Mickel & $.07-.10$ & $.033-.180$ & $.0029-.00$ & $033-.180$ & .176 & .041 & .נ11 & .182 & 2.58 & .628 & $n / e$ & .011 & .1 \\
\hline Selenluar & $.14-1.51$ & $.12-.28$ & $.036-.112$ & $.12-.28$ & .031 & .022 & .12 & .2m & .28 & .651 & .11 & .015 & .2 \\
\hline Cabalt & .018 & $.005-.032$ & $.0004-.28$ & cos-.032 & .024 & .026 & .014 & .013 & .24 & .285 & .011 & $<.0056$ & .05 \\
\hline Molybdencos & $: 0091$ & .094 & .026 & .094 & .658 & .430 & .029 & .094 & 2.17 & .630 & $n / 0$ & .0016 & .02 \\
\hline Cactaliun & $.011-.025$ & .029 & $.00018-.0011$ & .029 & .014 & .070 & $<.0015$ & $<.038$ & .055 & .111 & .0027 & $<.0022$ & .008 \\
\hline Mercury & $.012-.011$ & $.39-.98$ & $.0003-.011$ & $.39-.98$ & .09 & .870 & .016 & .979 & .081 & .961 & .021 & .00016 & .05 \\
\hline Derylilu & $.0010-.0011$ & .005 & $n / s$ & $n / s$ & .0022 & .007 & 8.004 & $<.020$ & .024 & .065 & $n / 0$ & .002 & .004 \\
\hline Vanedicu & $.034-.100$ & $.009-.024$ & $n / 0^{\circ}$ & $n / e$ & .75 & .025 & .24 & .024 & 2.35 & .249 & .22 & .032 & .1 \\
\hline Ant Imony & $.0022-.016$ & $.039-.270$ & $n / 4$ & $n / \bullet$ & .003 & .006 & .0029 & .039 & .16 &.$m$ & .055 & .00049 & .005 \\
\hline Barlum & .36 & $.009-.026$ & $.18-5.67$ & $.009-.026$ & .13 & .008 & $<.24$ & .001 & $<5.50$ & $<.016$ & .083 & 7 & .1 \\
\hline Boron & .21 & .005 & $n / 0$ & $n / 0$ & 1.22 & .059 & .91 & .041 & 53.6 & .541 & $n / 0$ & .162 & .2 \\
\hline Copper & .0038 & .008 & $.056-.098$ & .008 & .11 & .007 & .12 & .008 & 1.69 & .289 & $n / 4$ & .035 & .04 \\
\hline
\end{tabular}


presented in this paper, it is assumed that there is no $\mathrm{SO}_{2}$ scrubbing. Installation of high-level $\mathrm{SO}_{2}$ control would alter the projections of emissions of mercury, selenium, and arsenic. A few other elements (perhaps molybdenum) might also be affected.

To obtain estimates and projections of total trace element emissions, the last column of Table 1 was multiplied by projections of total Southwestern coal-fired power output developed as part of a large project at the University of New Mexico [6]. The projections of Southwestern coalfired power capacity appear in Table 2.

Using Tables 1 and 2 , it is possible to make estimates of total trace element emissions. I/ These estimates and projections appear in Tables 3-7.

For the preceding estimates we assumed all power stations in the Southwest to onerate with electrostatic precipitators of efficiency 295\% in both 1975 and 2000 . Although this is a reasonable assumption for year 2000, it is not valid for 1975. The assumption was made for reasons of lack of better knowledge and computational convenience. In fact, power stations in the aggregate did not achieve this collection efficiency, and our estimates of trace element emissions for 1975 are more of a lower bound for what actually occurred.

To obtain an idea about the relative magnitude of these emission rates, two comparisons are presented below. First, the amounts of a specific trace element--cadmium--that are disposed are listed by industrial source. Second, a comparison of trace metal emissions from power plant load factors must be made. We assumed the latter to be $70 \%$. 
Table 2

Projections of Southwestern Coal-Fired Plant Capacity, Aw.

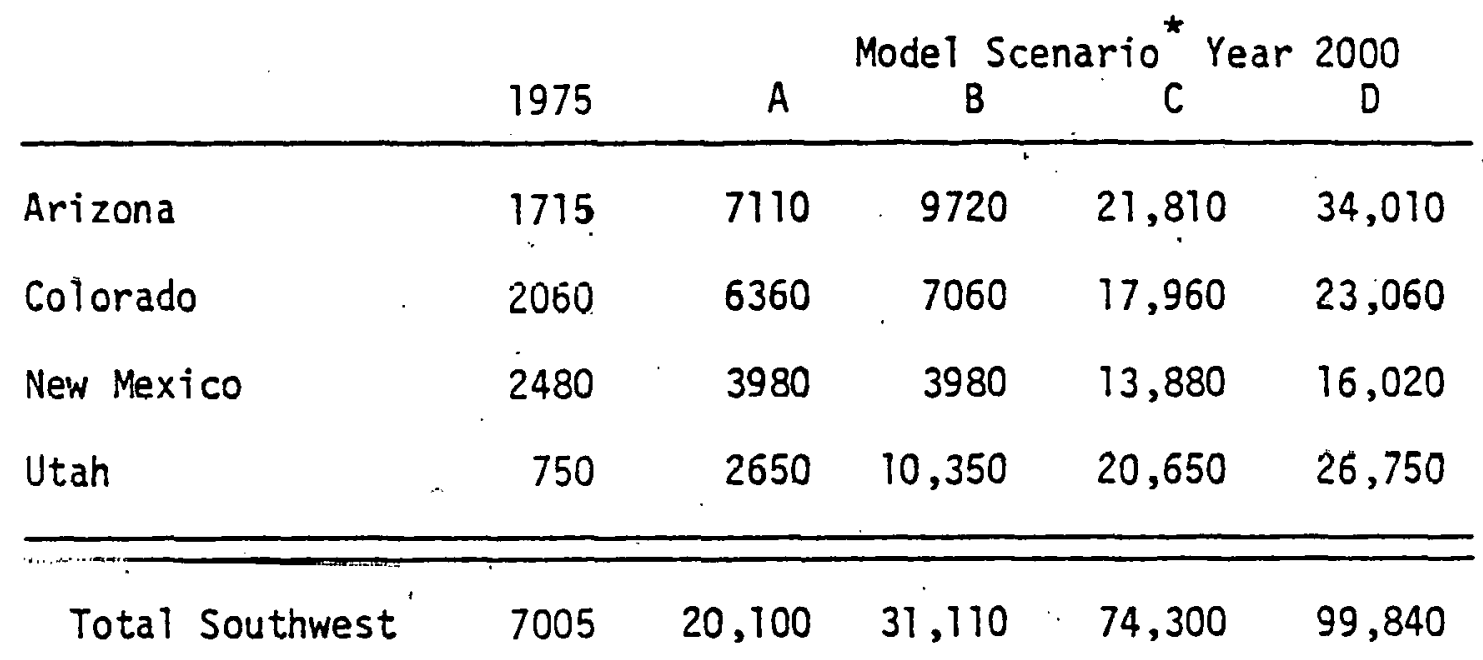

* Scenarios $B$ and $C$ of the Southwestern Economic and Energy Mode 1 may be Lermed "medium" projections: Scenarin $D$ represents a very high amount of Southwestern economic and energy development; and Scenario A may be viewed as a "low" projection. 
Table 3

Trace Element Emissions from Coal-Fired Power Plants (kg/year)

Total Southwest Region

\begin{tabular}{|c|c|c|c|c|c|}
\hline \multirow[b]{2}{*}{ Element } & \multirow[b]{2}{*}{1975} & \multicolumn{4}{|c|}{ Year 2000 Model Scenario: } \\
\hline & & A & 8 & $c$ & 0 \\
\hline Fluorine & 85,950 & 246,600 & 381,510 & 911,310 & $1,224,520$ \\
\hline Manganese & 8,590 & 24,660 & 38,150 & 91,130 & $122 ; 450$ \\
\hline Uranium & 210 & 620 & 950 & 2,280 & 3,060 \\
\hline Titanium & 64,460 & 184,950 & 286,130 & 683,480 & 918,390 \\
\hline Chromium & 12,890 & 36,990 & 57,230 & 136,700 & 183,680 \\
\hline Zinc & 17,190 & 49,320 & 76,300 & 182,260 & 244,900 \\
\hline Lead & 4,300 & 12,330 & 19,080 & 45,560 & 61,230 \\
\hline Arsenic & 1,290 & 3,700 & 5,720 & 13,670 & 18,370 \\
\hline Nickel & 17,190 & 49,320 & 76,300 & 182,260 & 244,900 \\
\hline Selenium & 8,590 & 24,660 & 38,150 & 91,130 & 122,450 \\
\hline Cobalt & 2,150 & 6,160 & 9,540 & 22,780 & 30,610 \\
\hline Molybdenum & 860 & 2,470 & 3,820 & 9,110 & 12,250 \\
\hline Cadmium & 340 & 990 & 1,530 & 3,650 & 4,900 \\
\hline Mercury & 2,150 & 6,160 & 9,540 & 22,780 & 30,610 \\
\hline Beryllium & 170 & 490 & 760 & 1,820 & 2,450 \\
\hline Vanadium & 4,300 & 12,330 & 19,075 & 45,560 & 61,230 \\
\hline Antimony & 210 & 120 & 950 & 2,280 & 3,060 \\
\hline Barium & 17,190 & 49,320 & 76,300 & 182,260 & 244,900 \\
\hline Boron & 8,590 & 24,660 & 38,150 & 91,130 & 122,450 \\
\hline Copper. & 1,720 & 4,930 & 7,630 & 18,230 & 24,490 \\
\hline
\end{tabular}


Table 4

Trace Element Emissions from Coal-Fired Power Plants ( $\mathrm{kg} /$ year) Arizona

\begin{tabular}{|c|c|c|c|c|c|}
\hline \multirow[b]{2}{*}{ Element } & \multirow[b]{2}{*}{1975} & \multicolumn{4}{|c|}{ Year 2000 Model Scenario } \\
\hline & & A & B & C & D \\
\hline Fluorine & 21,040 & 87,260 & 119,150 & 267,540 & 417,160 \\
\hline Manganese & 2,100 & 8,730 & 11,910 & 26,750 & 41,720 \\
\hline Urnaium & 50 & 220 & 300 & 670 & 1,040 \\
\hline Titanium & 15,780 & 65,440 & 89,360 & 200,650 & 312,870 \\
\hline Chromium & 3,160 & 13,090 & 17,870 & 40,130 & 62,570 \\
\hline Zinc & 4,210 & 17,450 & 23,830 & 53,510 & 83,430 \\
\hline Lead & 1,050 & 4,370 & 5,960 & 13,380 & 20,860 \\
\hline Arsenic & 320 & 1,310 & 1,790 & 4,010 & 6,260 \\
\hline Nicke1 & 4,210 & 17,450 & 23,830 & 53,510 & 83,430 \\
\hline Selenium & 2,100 & 8,730 & 11,910 & 26,750 & 41,720 \\
\hline Cobalt & 530 & 2,180 & 2,980 & 6,690 & 10,430 \\
\hline Molybdenum & 210 & 870 & 1,190 & 2,680 & 4,170 \\
\hline Cadmium & 80 & 350 & 480 & 1,070 & 1,670 \\
\hline Mercury & 530 & 2,180 & 2,980 & 6,690 & 10,430 \\
\hline Beryllium & 40 & 170 & 240 & 540 & 830 \\
\hline Vanadium & 1,050 & 4,360 & 5,960 & 13,380 & 20,860 \\
\hline Antimony & 50 & 220 & 300 & 670 & 1,040 \\
\hline Barium & 4,210 & 17,450 & 23,830 & 53,510 & 83,430 \\
\hline Boron & 2,100 & 8,730 & 11,910 & 26,750 & 41,720 \\
\hline Copper & 420 & 1,740 & 2,380 & 5,350 & 8,340 \\
\hline
\end{tabular}


Jable 5

Trace Element Emissions from Coal-Fired Power Plants ( $\mathrm{kg} /$ year) Colorado

\begin{tabular}{|c|c|c|c|c|c|}
\hline Element & 1975 & A & $\begin{array}{c}\text { Year } 2000 \text { Model } \\
\text { B }\end{array}$ & $\begin{array}{l}\text { Scenario } \\
\text { C }\end{array}$ & 0 \\
\hline Fluorine & 25,230 & 77,960 & 86,550 & 220,220 & 282,770 \\
\hline Manganese & 2,520 & 7,800 & 8,650 & 22,020 & 28,280 \\
\hline Uranium & 60 & 190 & 220 & 560 & 710 \\
\hline Titanium & 18,920 & 58,470 & 64,910 & 165,170 & 212,080 \\
\hline Chromium & 3,780 & 11,690 & 12,980 & 33,030 & 42,420 \\
\hline Zinc & 5,040 & 15,590 & 17,310 & 44,040 & 56,550 \\
\hline Lead & 1,260 & 3,900 & 4,330 & 11,010 & 14,140 \\
\hline Arsenic & 380 & 1,170 & 1,300 & 3,300 & 4,240 \\
\hline Nickel & 5,040 & $.15,590$ & 17,310 & 44,040 & 56,550 \\
\hline Selenium & 2,520 & 7,800 & 8,650 & 22,020 & 28,280 \\
\hline Cobalt & 630 & 1,950 & 2,160 & 5,510 & 7,070 \\
\hline Molybdenum. & 250 & 780 & 860 & 2,200 . & 2,830 \\
\hline Cadmium & 100 & 310 & 350 & 880 & 1,130 \\
\hline Mercury & 630 & 1,950 & 2,160 & 5,510 & 7,070 \\
\hline Beryllium & 50 & 160 & 170 & 440 & 560 \\
\hline Variadium & 1,260 & 3,900 & 4,330 & 11,010 & 14,140 \\
\hline Antimony & 60 & 190 & 210 & 550 & 710 \\
\hline Barium & 5,040 & 15,590 & 17,310 & 44,040 & 56,550 \\
\hline Boron & 2,520 & 7,800 & 8,650 & 22,020 & 28,280 \\
\hline Copper & 500 & 1,560 & 1,730 & 4,400 & 5,660 \\
\hline
\end{tabular}


Table 6

Trace Element Emissions from Coal-Fired Power Plants ( $\mathrm{kg} /$ year) New Mexico

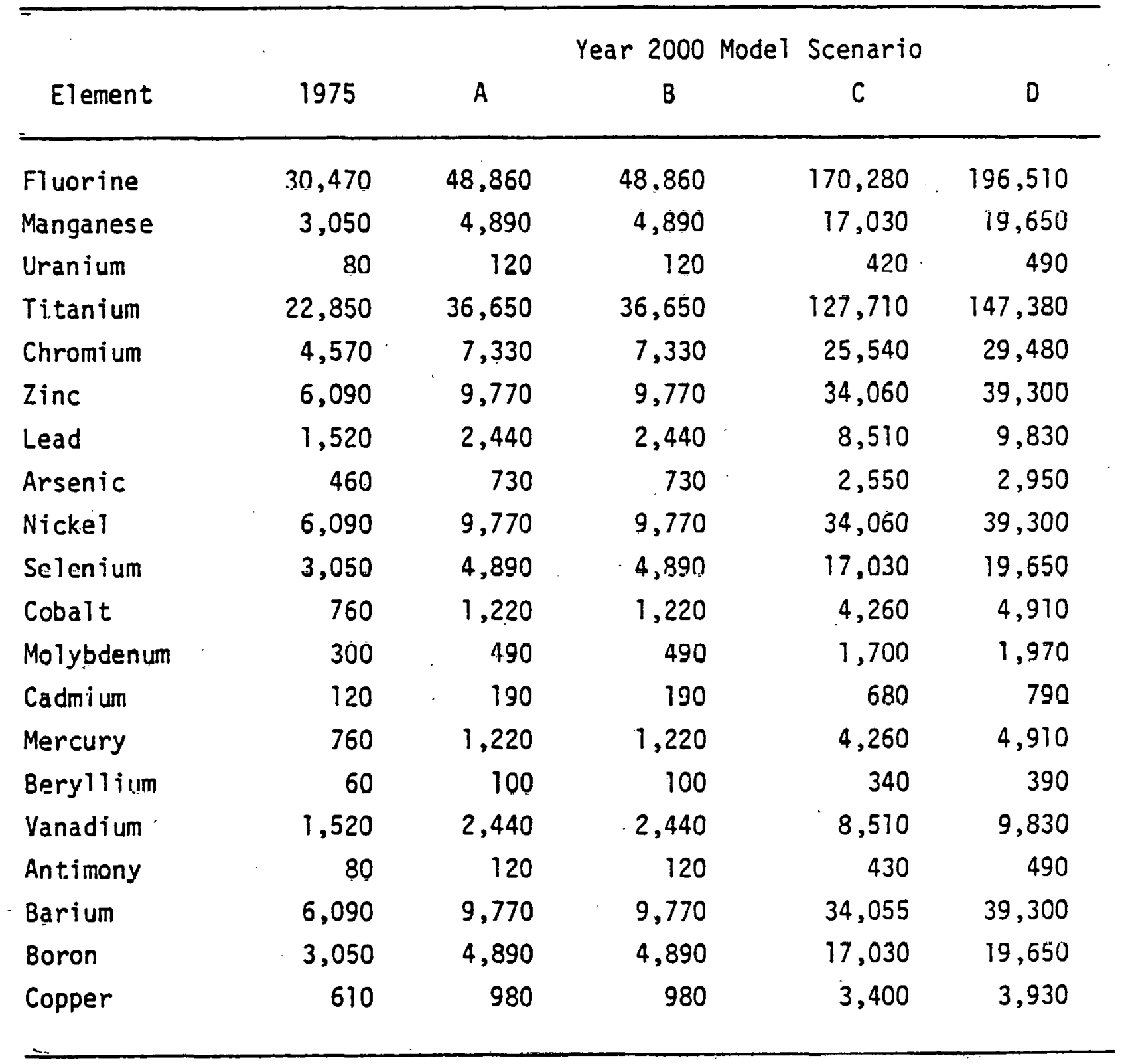


Table 7

Trace Element Emissions from Coal-Fired Power Plants (kg/year) Utah

\begin{tabular}{|c|c|c|c|c|c|}
\hline & & & Year 2000 Model & Scenario & \\
\hline Element & 1975 & $A$ & B & C & 0 \\
\hline Fluorine & 9,290 & 32,520 & 126,950 & 253,270 & 328,080 \\
\hline Manganese & 920 & 3,250 & 12,690 & 25,330 & 32,810 \\
\hline Uranium & 20 & 80 & 320 & 630 & 820 \\
\hline Titanium & 6,910 & 24,390 & 95,210 & 189,950 & 246,060 \\
\hline Chromium & 1,390 & 4,880 & 19,040 & 37,990 & 49,210 \\
\hline Zinc & 1,840 & 6,500 & 25,390 & 50,650 & 65,620 \\
\hline Lead & 460 & 1,630 & 6,350 & 12,670 & 16,400 \\
\hline Arsenic & $T 40$ & 490 & 1,900 & 3,800 & 4,920 \\
\hline Nickel & 1,840 & 6,500 & 25,390 & 50,650 & 65,620 \\
\hline Selenium & 920 & 3,250 & 12,690 & 25,330 & 32,810 \\
\hline Cobalt & 230 & 810 & 3,170 & 6,330 & 8,200 \\
\hline Molybdenum & 90 & 320 & 1,270 & 2,530 & 3,280 \\
\hline Cadmium & 40 & 130 & 1,510 & 1,010 & 1,310 \\
\hline Mercury & 230 & 810 & 3,170 & 6,330 & 8,200 \\
\hline Beryllium & 20 & 60 & 250 & 570 & 660 \\
\hline Vanadium & 460 & 1,630 & 6,350 & 12,660 & 16,400 \\
\hline Antimony & 20 & 80 & 320 & 630 & 820 \\
\hline Barium & 1,840 & 6,500 & 25,390 & 50,650 & 65,620 \\
\hline Boron & 920 & 3,250 & 12,690 & 25,330 & 32,810 \\
\hline Copper & 180 & 650 & 2,540 & 5,060 & 6,560 \\
\hline
\end{tabular}


power plants with those of copper smelters is made.

A report prepared by Stanford Research Institute in 1977 [7] contains an attempt to 1 ist all cadmium emissions to the atmosphere, water and land. Data presented in this report appear in Table 8.

The data in Table 8 refer to 1968, and some material flows have changed significantly in the past ten years. For example, atmospheric emissions of cadmium are probably lower now and amounts of cadmium disposed to land are probably higher than in.1968. Some significant aspects of the data are:

-- Coal-fired power plants are the second largest contributors of cadmium atmospheric emissions. Most cadmium is produced by zinc, lead, and copper smelters as a co-product, and those producers are the major source of atmospheric cadmium. But coal-fired power plants are important contributors:

-- Most of the cadmium disposed to land comes from wastes. disposed by industrial users to municipal sewers and landfills. But coal-fired power plants also contribute substantial amounts of cadmium to the land in disposed bottom ash and fly ash.

Another comparison that may be helpful in discussing the magnitude of trace element emissions involyes copper smelters as shown in Table 9. In the Southwest, copper smelters have larger emissions of trace metals than coal-fired power plants. Actually, these two industries are probably the major contributors of atmospheric trace metals in the region. It should be noted that making the comparison in terms of copper, zinc, 
Table 8

Cadmium Emissions to:
$\begin{gathered}\text { Atmosphere } \\ \text { (Tons/yr) }\end{gathered}$ (Tons/yr) (Tons/yr)

Zinc, Lead, and Copper Smciters \& Refineries

9ீ人்

Industrial Users

(Electroplating, Pigments,

Alloys, Electronics, etc.)

15

11

Wastes Disposed to sewers, incinerated, landfilled, etc. $\quad 5 \quad 352$

Solid Waste Disposal

31

15

2043

Waste from remelting and reuse

100

900

Emissions from Phosphate

Fertilizer Industry

1

87

Emissions from Coal-Fired

Power Plants

235

744

Emissions from Motor

Vehicles

11

Emissions from 0il-Fired

Power Plants \& other

0it Uses

36

Emissions from Cement Plants

32

Total

1418

175

4137 
Table 9

Trace Metal Atmospheric Emissions at Southwestern

Power Plants and Southwestern Copper Smelters (total)

\begin{tabular}{lcc}
\hline Element & $\begin{array}{c}\text { Southwestern } \\
\text { Copper Sme1 ters* } \\
(\mathrm{kg} / \mathrm{yr} .)\end{array}$ & $\begin{array}{c}\text { Southwestern } \\
\text { Coal-Fired Power P1ant } \\
(\mathrm{kg} / \mathrm{yr} .)\end{array}$ \\
\hline Copper & 159,000 & 1720 \\
Zinc & 48,000 & 17,190 \\
Lead & 21,000 & 4300 \\
Arsenic & 1600 & 1290 \\
\hline
\end{tabular}

*Based upon data prepared by Bonem and Mead [8]. 
and lead emissions may overstate the relative magnitude of smelter emissions because these are the major metals coming from smelters. For example, total Southwest smelter emissions of copper are about 100 times larger than power plant copper emissions. But smelter emissions of arsenic are only 1.2 times larger than those from power plants. An additional point is that the Southwest contains about $70 \%$ of U. S. copper smelting capacity. This means that the table above may understate the problem of trace element emissions from coal-fired power plants in the U.S. although smelters are a larger problem in the Southwest.

A final source of information on the importance of trace element emissions from coal-fired power plants relative to other industries is a table presented by Lim [9]. This table, reproduced here as Table 10 and prepared by Goldberg [10] refers to trace element emissions to any environmental receiver, i.e., air land, or water. It is clear that the metals industry and the electric power industry (both coal-fired and oil-fired boilers) are major sources of trace element emissions. 
Table 10

Sources and Amounts of Trace Element Emissions

\begin{tabular}{|c|c|c|c|c|}
\hline Element & $\begin{array}{l}\text { Total* } \\
\text { Emissions } \\
\text { (tons/yr.) }\end{array}$ & $\begin{array}{c}\text { Principal Emission } \\
\text { Source }\end{array}$ & $\begin{array}{l}\text { Emissions } \\
\quad \text { from } \\
\text { Principal } \\
\text { Source } \\
\text { (tons/yr.) }\end{array}$ & $\begin{array}{l}\text { Emissions } \\
\text { from } \\
\text { Coal-Fired } \\
\text { Boilers } \\
\text { (tons/yr.) }\end{array}$ \\
\hline Arronic & 8.134 & Pectiride use & 2,662 & 541 \\
\hline Barium & 9,852 & Barium Chemicals & 4,004 & 2,958 \\
\hline Beryl1ium & 131 & Coal-fired boilers & 111 & .111 \\
\hline Boron & 8,627 & Coal-firsd boilers & 3,346 & 3,346 \\
\hline Cadmium & 2,746 & Iron and steel furnaces & 910 & n.a. \\
\hline Chromium & 10,925 & Coal-fired boilers & 7,019 & 7,019 \\
\hline Copper & 12,251 & Primary copper industry & 7,917 & 737 \\
\hline Fluorides & 145,798 & Iron and steel industry & 42,224 & 31,120 \\
\hline Lead & 8,445 & Secondary lead industry & 1,838 & 774 \\
\hline Manganese & 17,284 & Ferro-alloy preparation & 4,352 & 1,775 \\
\hline Mercury & 721 & Consumption of paint & 196 & 188 \\
\hline Nickel & 5,446 & 0il-fired boilers & 3,252 & 124 \\
\hline Selentum & 778 & Coal-fired boilers & 453 & 453 \\
\hline $\operatorname{Tin}$ & 324 & Iron and steel iridustry & 237 & 86 \\
\hline Vanadium & 16,264 & 0il-fired boilers & 10,073 & 1,278 \\
\hline Zinc & 137,097 & Primary zinc industry & 45,500 & 3,097 \\
\hline
\end{tabular}

*Emissions include wastes disposed to air, land, and water.

Source: M. Y. Lim [9], p. 29. 


\section{B. Atmospheric Dispersion and Deposition of Trace Elements}

Emission rates of trace elements have been discussed in the preceding paragraphs, and attention is now directed to the question of how these elements are dispersed through the atmosphere and settle on the earth's surface. The questions of atmospheric dispersion and soil deposition are addressed in six subsections below.

First, it may be noted that there are two important considerations with respect to trace elements; one is the chemical composition and the other is the form. The chemical composition is important because it may influence the removal processes which affect the material. For example gases may be absorbed by soil, plant, or water surfaces at different rates depending upon their chemical composition. Gases generally behave much differently than do small particles. Small particles are usually absorbed much less efficiently during interaction with the ground. The physical size and shape of partićles also influences the rate at which they are deposited. Very small particles $<0.1$ micron are removed by brownian diffusion to surfaces while larger particles wili settle out. However for particles in the range 0.1 to 5.0 micron deposition occurs slowly and it is exactly this range in which trace elements are emitted from well controlled facilities.

1. Qualitative Description of the Transportation and Transformation of Pollutants

Materials released from power plant stacks are released well above the surface. The effective height of the release depends upon the physical stack height and the plume rise. The plume rise is determined by the 
volume of the gases relew ad per unit time, the temperature of the gases, the wind speed, temperature and air stability of the ambient atmosphere. Once the material has reached the effective plume height it drifts with the wind and spreads both in the horizontal and the vertical dimensions. The rate of spreading depends upon atmospheric stability which is related to the time of day and to general circulation features (storms, fronts, high pressure areas, etc.).

During stable conditions, which usually occur in the evening or the morning in conjunction with clear skies, the pollutants may be diluted very slowly because vertical motion is inhibited during stable conditions (an inversion where the temperature increases with height is an example of stable condition). Under these conditions the pollutants may travel large distances without being removed because the elevated material may not spread enough to reach the ground and because there would be no rain to wash the material out. For power plant emissions in flat terrain the emissions are unlikely to be removed until the stability changes because the materials will not mix to the ground for distances in excess of 100 kilometers. If there is high terrain present the material may come in contact with the ground so that removal is possible.

During neutral or unstable conditions the pollutants mix more rapidly and thus can become attached to plant, soil or water surfaces. This attachment is known as dry deposition. The rate at which attachment occurs depends upon the material and the character of the surface. Surfaces with large roughness elements such as forests tend to absorb more of the pollutants when exposed to the same concentrations.

Rainfall or snowfall may also be instrumental in removing pollutants. 
In this context there are two possible mechanisms, one is called rainout and the other washout. Rainout occurs when droplets formed above the pollutants fall through the pollutants and collect and deposit a portion of the pollutants. Washout occurs when the pollutants are incorporated into the droplets as they form and before they begin to fall. Generally the washout mechanism is significantly less effective than the rainout mechanism with the result that pollutants at the cloud forming height are more rapidly removed than those below the cloud base.

\section{Relevant Characteristics of the Southwest Region}

The Southwestern U.S: is made up of a complex of mountain ranges, valleys, and plains. The lowest portions occur in the southern and southwestern borders of the region. With the exception of the eastern plains which comprises the land mass east of the latitude of Denver there is an abundance of topographical relief. Over most of the region the relief is composed of valleys and relatively small mountain ranges. However, there are three major mountainous areas in the region. One is composed of the Rocky Mountain chain which covers the west central region of Colorado and extends into northern New Mexico. The second is a south-north range which extends through east central Utah. The third is a range running northwest to soucheast which extends from north central Arizoria to southwestern New Mexico. There are other isolated mountainous areas but these three areas represent the major barriers to moisture transport and, to some extent, pollution transport.

The principal existing sources are located in major river valleys, primarily in the western portion of the eastern plains. Additional 
development is expected to continue the current pattern with some extension to the west and south and perhaps less development near the parklands of north-central Arizona and south central Utah.

The mountain ranges of the region are very significant from the standpoint of the transport and fate of trace elements. On a small scale they tend to trap cold air in the bottom of the valley during the winter with the result that pollution levels can build up over several days. For elevated sources they make possible the occurence of high concentrations on terrain at the approximate height of the emission.

On a regional scale the mountains act as major collection areas. For dry deposition the mountains are effective collectors because of greatly increased roughness elements; trees, rocks, and canyons and ridges and because the slopes themselves produce processes which change the effective stability. For example, during the nighttime, stable condition drainage winds will develop which cause air near the ridge faces to be drawn into the valley bottom. Furthermore the mountains themselves act as huge roughness elements which change stable conditions into mechanically driven neutral or unstable. During daytime conditions heating of the sunlit slopes produces updrafts which accelerate mixing. Figure 1 illustrates the difference in ground cover which occurs in the mountains [11].

In the case of wet deposition the mountains have much greater rainfall and snowfall associated with them than do the lower elevations. In many instances a particular air mass will have no rainfall associated with it until it reaches a mountain area. The resulting lifting and air mass cooling will produce rain or snow with greatly increased deposition. Figure 2 displays the runoff patterns in the Southwest [12]. 
Figure 1

Major Forest Types of the Six Rocky Mountain States

WESTERN FORESTS
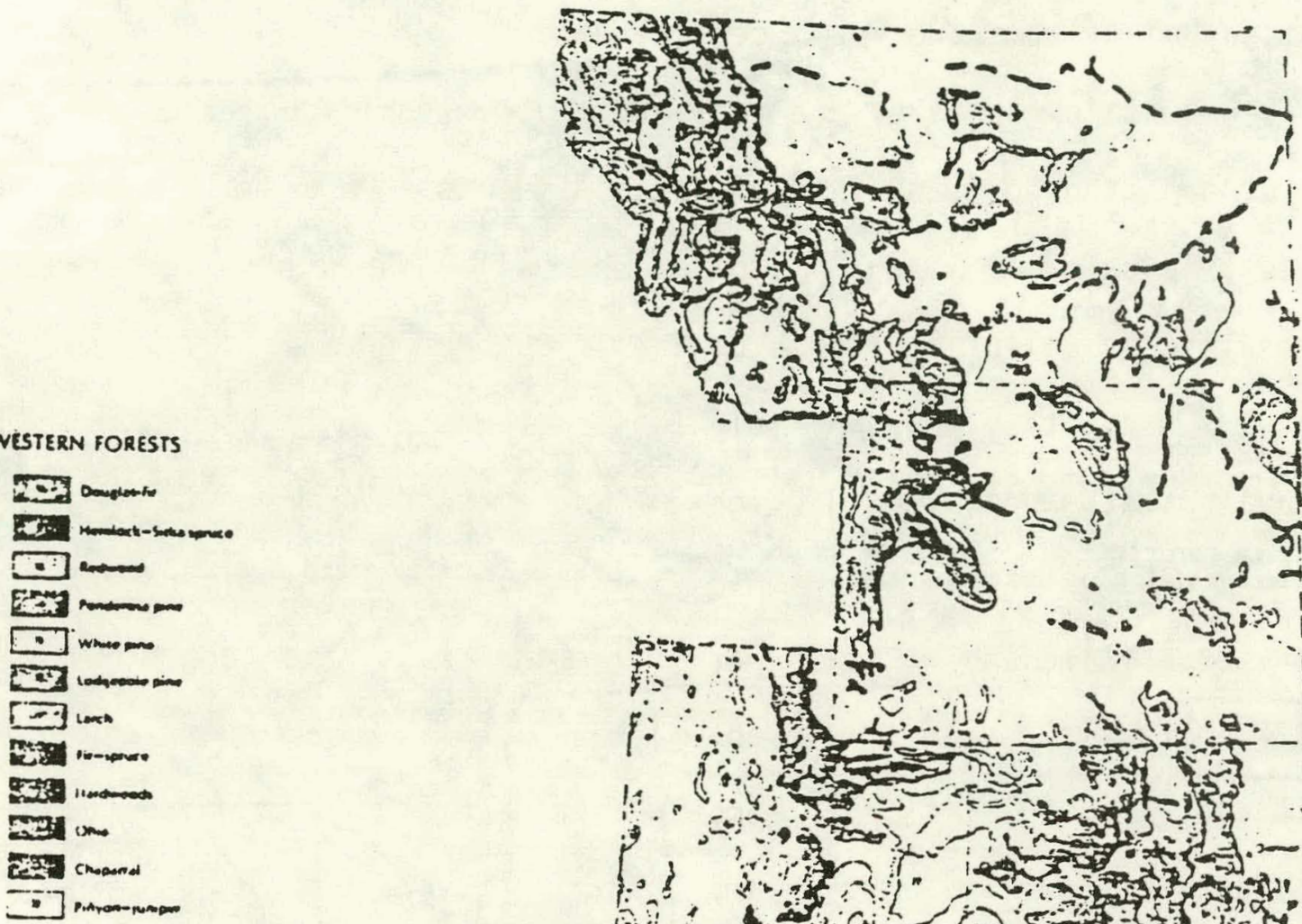

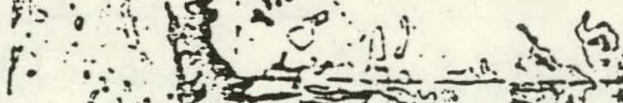

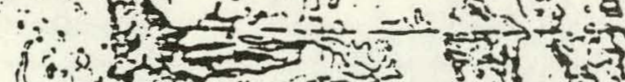

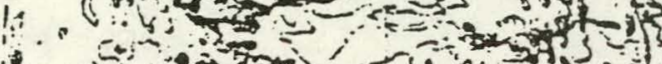

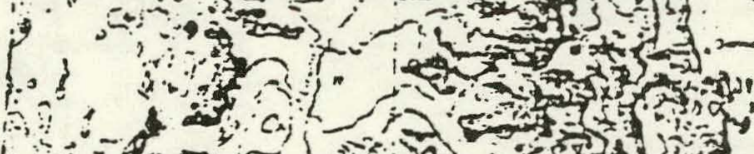

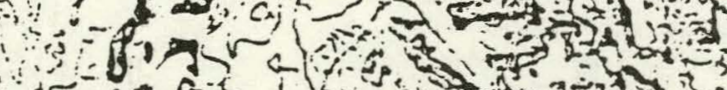
a $=0$,

NONEOREST

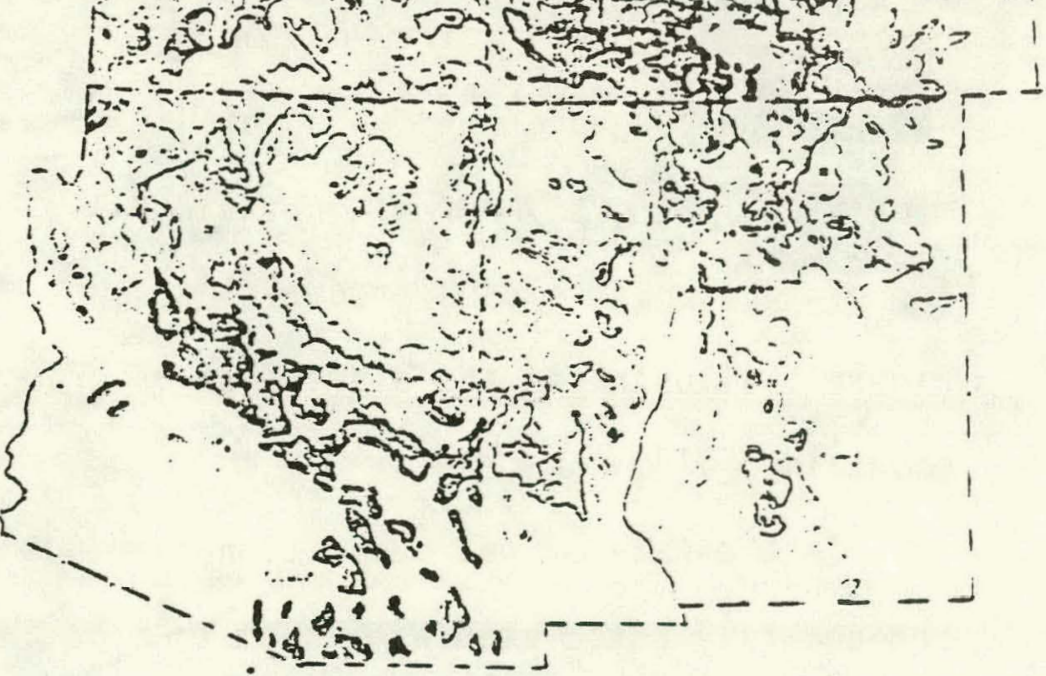

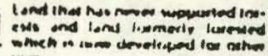

Source: US Geological Survey, US Forest Service Information, "National Atlas of the United States of America -- 1967," (1970). 
Figure 2

Average Annual Runoff - Rocky Mountain Region

AVERAGE ANNUAL

RUNOFF

Inches
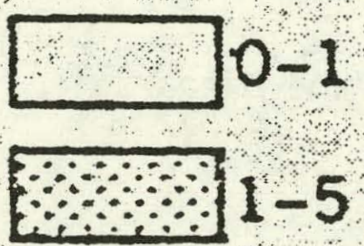

$5-20$

20-40

Orer 40

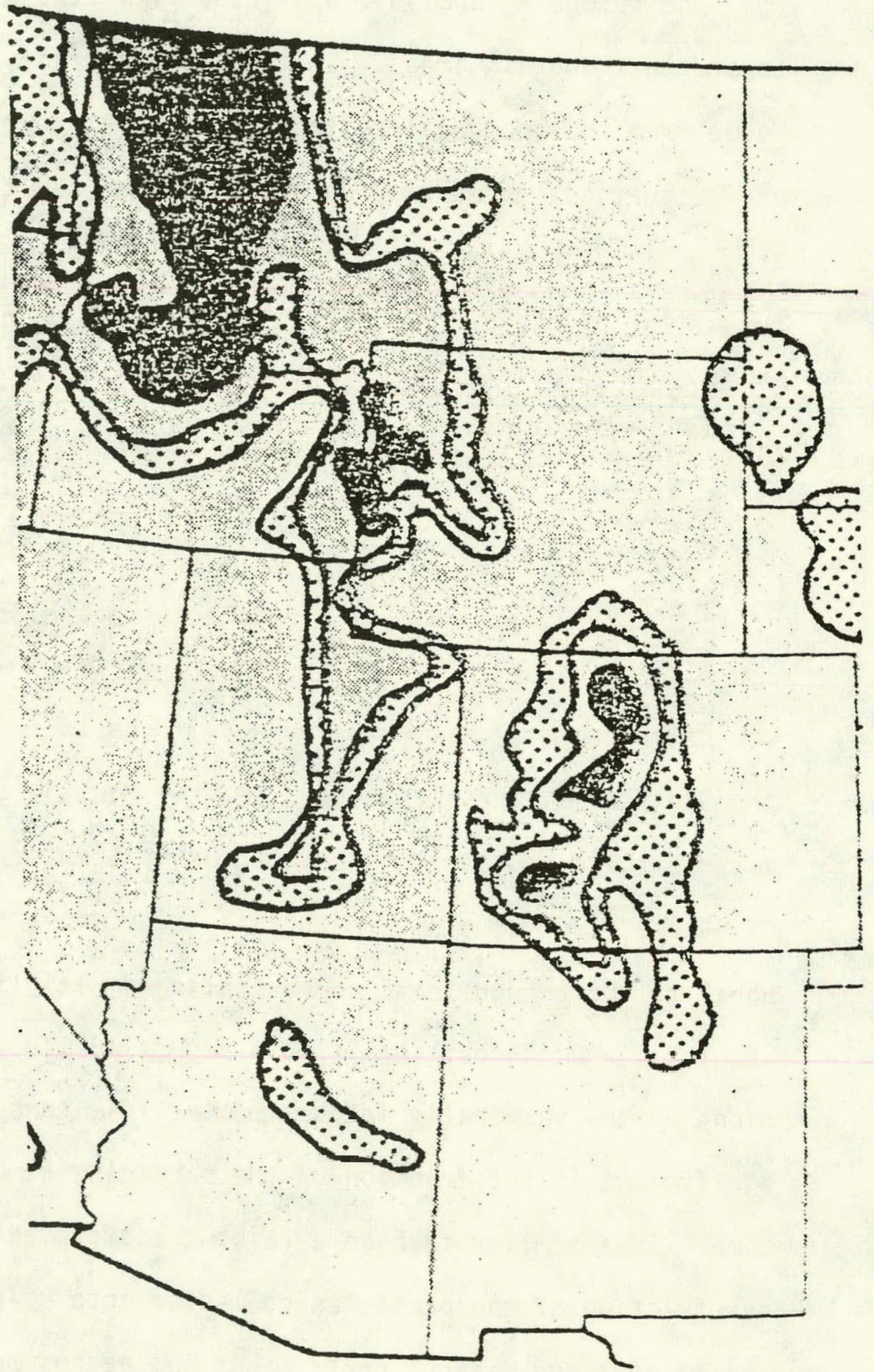

Source: US Department of Agriculture, Forest Service, "The Nation's Renewable Resources - An Assessment, 1975," Forest Resource Report Number 21, US Government Printing Office, Washington, D.C. (June 1977), p. 213. 
The marked increase in runoff associated with mountain areas is quite evident.

The foregoing analysis applies only if the winds carry the pollutants toward the mountain areas. In the Southwest the prevailing winds tend to be from the southwest to the northeast although there is a large amount of fluctuation in the wind direction. The result is that emissions from the energy producing areas of the west and southwest are frequently carried toward the mountain areas. Facilities located in the plains would be less likely to contribute trace elements to mountain regions. Table 11 gives the joint frequency of stability and wind direction for Winslow, Arizona [13].

3. Analytical Tools for Prediction of Pollutant Removal and Dispersal

There are basically three techniques which have been used to deal with pollutant transport and removal. The most frequently used model is the Gaussian dispersion model. In this model the concentrations are assumed to be normally distributed about the vertical and horizontal distances from the plume centerline. Dry deposition is assumed to be equal to the ground level concentrations multiplied by the deposition velocity. Wet deposition is obtained by multiplying the washout coefficient by the vertically integrated particle concentration. The washout coefficient is the fraction of the particles removed by rainfall in unit time. In a similar fashion a rainout coefficient is defined which describes the fraction of the particles collected into raindrops per unit time. Both the rainout and washout coefficient approaches require details about the cloud behavior which are difficult to obtain. Instead one frequently 
Table 11

Frequency of Occurrence of Each of Six Stability

Categories by Wind Direction and Speed at Winslow, Arizona*

\begin{tabular}{lllllll}
\hline & $A$ & $B$ & $C$ & $D$ & $E$ & $F$ \\
\hline N & 0.3 & 0.7 & 1.0 & 2.9 & 1.9 & 2.9 \\
NE & 0.2 & 0.3 & 0.5 & 1.4 & 1.0 & 1.4 \\
E & 0.2 & 0.4 & 0.6 & 1.7 & 1.1 & 1.7 \\
SE & 0.1 & 0.2 & 0.9 & 3.8 & 3.2 & 4.4 \\
S & 0.1 & 0.3 & 1.0 & 4.4 & 3.6 & 5.0 \\
SW & 0.2 & 0.5 & 1.6 & 6.8 & 5.7 & 8.0 \\
W & 0.3 & 0.8 & 1.3 & 5.0 & 3.8 & 5.3 \\
NW & 0.4 & 0.9 & 1.3 & 4.0 & 2.7 & 4.0 \\
Average Speed. 2 & 3 & 4 & 6 & 4 & 3 \\
\hline
\end{tabular}

For the purposes of this tabulation, the 6.5 percent frequency of calm has been equally distributed among the six stability. categories.

*Based on Winslow, Arizona, 150-meter winds and hourly airport observations. November 196.1 to December 1964. 
defines a washout ratio. The latter is the ratio of the concentration of the contaminant in rainwater to the concentration in the ambient air.

In this case the flux of material removed from the plume is merely the rainout coefficient times the precipitation rate times the ambient concentration.

With the Gaussian model pollutant depletion is usually assumed to occur uniformly throughout the plume with the result that the effective emission rate at a downwind distance is merely the original emission rate minus the amount of material removed.

There are several difficulties with the Gaussian model some of which are easily corrected while others cannot be easily remedied. First the Gaussian model was derived for an atmosphere with uniform stability. Frequently in the actual atmosphere there are layers which retard the dilution of materials and act to reflect contaminants into layers more faborable to dilution. If the contaminants are contained between the ground and the layers aloft multiple reflections will occur between the ground and the layer aloft with the result that concentrations will be uniformly mixed in the vertical. Gaussian models are frequently adjusted in this manner.

There are three other difficulties with the Gaussian model, and these are dealt with in one way or another. First, concentrations vary with horizontal and vertical distance from the plume centerline. Thus, the first problem is to determine the centerline of the plume. In the case of codes such as Hefters [14], the centerline is defined by interpolation between the winds found at adjacent s.tations and times. Unfortunately the required upper leyel winds are measured at 12 hour intervals at a 
relatively few stations in the west, ( 7 in the four Corners states). Furthermore the western stations are frequently influenced by topographical features so that the measured winds are representative of a relatively small area. Another related difficulty is that wind direction and speeds may vary greatly with height. Thus different portions of the plume may follow entirely different trajectories.

A second problem deals with the parameters used to define concentration distribution about the centerline. In actual fact these parameters should be a function of the time of day, cloud cover and wind speed at each point along the trajectory. Normally the codes do not attempt to treat changes in the stability. Usually a uniform yertieal concentration is assumed beneath a mixing layer while horizontal dispersion is specified by a single parameter. In this context a key question is the dispersion and other parameters used. For short distances, less than 100 kilometers, there are relationships developed for dispersion parameters; however, for distances on the order of $100-500$ kilometers there are few data to suggest what appropriate values may be.

One key difficulty with the Gaussian approach is the poor treatment of vertical dispersion with surface deposition. Dry deposition tends to deplete the material in the lower portion of the plume. During stable conditions vertical mixing is relatively. slow with the result that ground level concentration drop rapidly and thus deposition decreases. This effect can be partially compensated for with a lower deposition velocity.

\section{K-Theory}

In K-theory the flux of a quantity is assumed to be equal to the eddy diffusivity, $K$, multiplied by the gradient of the quantity. If the 
eddy diffusivity is constant one obtains an equation similar to that for heat conduction in a solid.

However, the evidence indicates that the eddy diffusivity is generally not constant with height near the surface. For this reason various forms involving non-constant $K$ 's have been used. For example, Fisher and Maul [15] have used a form in which $K$ is proportional to $Z$ at heights above the roughness height $Z_{0}$ up to a height $Z_{1}$, after which the diffusivity is constant; at a greater height, presumed to be the top of air mixed layer, the flux of material is set equal to zero. The variable $K$ also requires a variable wind speed with height.

A model using this formulation in the vertical and a Gaussian formulation for the horizontal has had some success in describing transport of sulfates from power plants in England. The K-theory approach does a much better job of handling surface depletion. Other models use this feature [16].

\section{Estimation Technique}

In order to provide an order of magnitude estimate of the deposition of trace elements a simplified model was constructed. The model treats dry deposition and wet deposition in an approximate fashion. The model utilized an assumption that the deposition occurs primarily after the plume has become uniformly mixed. This assumption permits an analytical solution to be obtained for the deposition at any point.

In order to compensate for the surface depletion of the fiux the deposition velocity was modified as suggested by Fisher and Maul. In their formulation the effective deposition velocity is reduced by a 
factor which depends upon the eddy diffusivity and plume height and the roughness scale height.

The unmodified deposition velocities were obtained from Reynold's analogy and relationships for friction velocity as a function of surface roughness [17]. Values of deposition velocity for mountainous areas were approximately twice those of flat land areas and the effective deposition velocities differed by even a larger amount. Wet deposition was obtained from the integrated concentration, the velocity, and a wet deposition factor. Since this factor is proportioned to annual rainfal1, ànnual averaged values are approximately 3 times higher in mountainous areas than in flat land areas. For this analys is it was presumed that all rainfall would occur during neutral statility in accordance with the Turner stability categorization scheme [18]. In flat land neutral conditions occur about $1 / 3$ of the time in the Southwest. Thus the rainout coefficient was increased three fold for neutral conditions and set equal. to zero for all other stabilities. For mountainous areas with three fold the rainfall of lower elevations the incidence of neutral conditions was increased two fold and the rainout coefficient during neutral conditions was increased by $50 \%$.

For deposition in mountainous areas the effective source strength was calculated as the distance of the mountains from the source for each stability category. For unstable and stable conditions a portion of the original category was assumed to become neutral stability with wet deposition and enhanced dry deposition while the remainder suffered enhanced dry deposition.

In this manner transfer coefficients were estimated for a receptor 
region in the southwestern mountains of Colorado associated with any of seven principal source regions. The source regions used were: (1) southwestern Arizona, (2) north central Arizona and southern Utah, (3) northeast Arizona, (4) central Utah, (5) southwestern Utah, (6) San Juan County, New Mexico, and (7) Rio Grande Valley New Mexico. The transfer coefficient gives the deposition rate per unit area and per unit source strength. It is a function of the distance to the receptor region from the source, the frequencies of the stability conditions associated with the wind direction which would carry the material to the receptor from the source. In this context Winslow, Arizona stabilities and wind direction frequencies were used. Forty-five degree sectors were used and the resulting deposition may be assumed to be ayerage values over a fortyfive degree sector.

The resulting values for transfer coefficients are described in Table 12. These values together with installed capacity appropriate to Scenario $D$ suggests that boron and selenium would be added to mountain soils at a rate of $.7 \mathrm{mg} / \mathrm{m}^{2}$ per year (see Table 13). These may be viewed as the highest deposition rates likely to occur in the next 20 years because Scenario $D$ is the "highest" scenario for coal-fired power production. In the flat land near a major facility, comparable or slightly greater additions would occur for selenium, boron and fluoride. The significance of these levels is not readily apparent.

5. Historical Perspective on Deposition Problems

There have been a number of cases where deposition of trace elements associated with industrial facilities have been identified with environmental 


\begin{abstract}
Table 12
Transfer Coefficients from Source Areas to

A Receptor Area in Southwest Colorado
\end{abstract}

\begin{tabular}{ll}
\hline Source Region & Coefficient $\times 10^{9} / \mathrm{m}^{2}$ \\
\hline Southwest Arizona & .00018 \\
North Central Arizona - Southern Utah & .0007 \\
Northeast Arizona & .0010 \\
Central Utah & .0010 \\
Southwest Utah & .0006 \\
San Juan County New Mexico & .0024 \\
Rio Grande Valley New Mexico & .0010 \\
\hline
\end{tabular}


Table 13

Deposition of Trace Elements

\begin{tabular}{ll}
\hline Element & Fallout Rate $\mathrm{mg} / \mathrm{m}^{2} \mathrm{yr}$. \\
\hline Fluorides & .68 \\
Manganese & .068 \\
Uranium & .0017 \\
Titanium & .51 \\
Chromium & .102 \\
Zinc & .136 \\
Lead & .034 \\
Arsenic & .0102 \\
Nickel & .136 \\
Selenium & .068 \\
Cobalt & .017 \\
Molybdenum & .0368 \\
Cadmium & .0027 \\
Mercury & .017 \\
Beryllium & .00136 \\
Vanadium & .034 \\
Antimony & .0017 \\
Barium & .136 \\
Boron & .068 \\
Copper & .0136 \\
& \\
\hline
\end{tabular}


problems. Most of the cases have been associated with smelters where high concentration of arsenic, or lead have damaged livestock, bees and plants. Smelters tend to have very large emissions of arsenic and lead, and may not be relevant to power plant situations.

However there have been three cases which are somewhat more relevant. One relates to the $k-33$ cooling tower at Oak Ridge [19]. Zinc and chromium concentration in vegetation were greatly increased near the tower due to drift losses from the tower. The source of the zinc and chromiun was an algae inhibitor added to the cooling water. Plant growth near the tower was greatly retarded.

In another instance a plant which burned lignite to extract uranfum from the ash released molybdenum which caused molybdenosis in cattle grazing nearby [20]. Another instance involyes a coal burning power plant in Montana [21]. Damage to vegetation was reported and while a fully definitive analys is has not yet been completed it appears that fluorides were responsible for the damage. Fluorlde concentrations in the plant tissue were significantly elevated; sulfur concentrations were also elevated but not nearly so much so.

On the other hand studies near a dirty southwestern power plant suggested that only selenium might be increased by plant emissions [22]. Based on this work there was little likelihood of acute damage associated with deposition of trace elements.

One item of concern is the relatively high deposition levels in mountainous areas. The values at distances of $150 \mathrm{~km}$ from the nearest source are comparable to those expected on flat land rrom much closer sources. This suggests that damage could extend over relatively large 
areas if it were to occur. Furthermore the potential for localized hot spots in both time and space should not be ignored. While the average burden over a large area over a year may not be great there may be high levels in localized areas for short times.

\section{Conclusions}

Mercury fallout over the approximately $4800 \mathrm{~km}^{2}$ of upper San Juan drainage would add about 80 kilograms per year to the watershed. A significant fraction of this might end up in Navajo Reservoir. Concentration in incoming waters would probably be less than $.035 \mathrm{ppb}$ on an annual basis. In some instances magnifications between water concentration and fish tissue concentration of 3000:1 have been reported. On this basis mercury concentrations in fish might increase by about $0.1 \mathrm{ppm}$. Fish in reservoirs already have excessive concentrations. Howeyer, these estimates must be viewed as highly tentative. First of all it is likely that several years of mercury additions will be retained in the reservoir, however, the fractionation between mercury in this water and mercury in sediment is poorly understood. Thus the potential for mercury contamination in fish tissue cannot be easily assessed.

Furthermore, it is likely that emission of trace elements will show wide variability with the coal being burned and the collectors used. In addition the potential for localized hot spots should not be ignored. Moreover these estimates ignore start-up conditions which may be responsible for significant emission.

In view of the past evidence of trace element effects and the long term nature of the threat a prudent course would involve monitoring trace element build-ups over the next several years. 
As a final note, it should be mentioned that a mathematical development of the dispersion model discussed above is available upon request. Details of the numerical calculations are also available upon request. 


\section{Appendix A to Chapter 2 \\ ENERGY RESOURCE DEVELCPMENT SCENARIOS \\ FOR THE FOUR CORNERS REGION}

The nature and scope of energy resource development to take place in the region will be determined through the interaction of a number of factors, both political and economic, that are extremely difficult to forecast. A $i$ ist of such factors would include the actions individually and collectively of the so-called OPEC countries, the substance of the "National Energy Policy" when that is finally established by Congress, the impact of developing energy technology, the nature of tax and subsidy programs relating to energy development and/or energy consumption, the extent and character of emission standards imposed and enforced, decisions concerning price controls on petroleum products and natural gas, court decisions concerning water rights and much more.

The construction of an accurate projection of future eneray resource development in the Southwest (the "probable" or "most likely" energy resource development scenario) would of course be of substantial value. Such a projection would permit us to anticipate with a high degree of accuracy the major eco-. nomic, demographic and environmental impacts associated with that development. However, given the uncertainty found in many of the factors that will finally determine the precise nature and scope of the region's energy resource deveropment, the construction of a "most likely" scenario becomes highly speculative. Because of the number and diversity of these factors it is unlikely that we can at this point in time accurately predict the behavior of the major parties involved or anticipate how each of these factors will impact Southwestern energy resource development over the next few decades. 
In fact, it is suggested that an effort to construct a "probable" or "most likely case" scenario may well be counter productive. Such an effort may result in attention being centered on an evaluation of how accurately researchers have projected specific elements of the anticipated energy resource development. Attention will thus be drawn away from the economic, demographic and environmental impacts associated with energy resource development.

\section{"POSSIBLE" ENERGY RESOURCE DEVELOPMENT SCENARIOS}

Rather than speculating about the "probable" or "most likely case" scenario of energy resource development in the region we have taken another approach. This alternative approach involves the construction of a series of "possible" energy resource development scenarios designed to illustrate the range of economic, demographic, and environmental impacts that may result from the development of the region's energy resources.

Following this approach the scenarios presented in this report reflect different levels of development of specific energy sources based on differing assumptions concerning energy demand, environmental constraints, energy technology, etc. All of the energy resource development scenarios are "possible", but none should be labeled "probable" or "most likely". As expressed by Jim Sawyer of Resources for the future "...specific scenarios are not predictions, but merely possible future events." (Sawyer, Brown, Abbey, 1976)

Several basic principles have guided the development of the four energy scenarios presented in this paper. Adherence to these principles contributes to both the acceptability and the usefulness of the resulting scenarios. The principles include the following: 
1. Recognized national energy scenarios were used to provide control totals for each specific type of energy resource development included in the regional scenarios.

2. Where possible planned and/or projected regional energy resource de-velopment as reported by the industry were used in the determination of the sequence and siting of energy development in the Four Corners states.

3. In the determination of sequence and siting of projected energy resource development (where industry plans were not available) careful attention was directed at the estimated energy reserves of the field to be developed and the water requirements for such development.

4. A wide range of energy resource development is included within the scenarios developed for the region and an even number of scenarios has been developed.

In the construction of the Four Corners energy resource development scenarios it was considered important that these scenarios would be consistent with recognized national energy scenarios and our current understanding of the region's potential for energy resource development.

\section{THE FOUR CORNERS. SCENARIOS}

The four scenarios that have been developed are summarized in Table 2.1. (Those participating in discussions resulting in the development of the Four Corners Scenarios include Allen V. Kneese, F. Lee Brown, Shaul Ben-David and Alfred Parker all of the University of New Mexico; James W. Sawyer, Jr., and David Abbey of Resources for the Future; Mike Williams of the John Muir Institute for Environmental Studies; and Fred Roach of Los Alamos Scientific Laboratories.) Scenario $A$ is considered a very conservative projection of future 
Table 2.1. Energy Resource Development Scanarios Sumary Table

Projected Electrical renerating Capacity, Coal Gasification Capacity, 0il Shale Capacity and Projected $\mathrm{U}_{3} \mathrm{O}_{8}$ Production in the Four Corners States

\begin{tabular}{|c|c|c|c|c|}
\hline & $\begin{array}{l}\text { Megawatts of } \\
\text { Electrical } \\
\text { Capacity }\end{array}$ & $\begin{array}{c}\text { Number of } \\
\text { Synnas Plants } \\
\left(250 \times 10^{6} \mathrm{ft}^{3}\right. \\
\text { per day })\end{array}$ & $\begin{array}{c}\text { Humber of } \\
\text { Syncrude Plants } \\
\text { [ni] Sinale }) \\
(50,000 \text { bal per day })\end{array}$ & $\begin{array}{l}\text { Tons of } \\
\text { Uranium Mined } \\
\text { (per year) }\end{array}$ \\
\hline 1975 (existing) & 15,400 & 0 & 0 & 6,470 \\
\hline Scenario A & 28,500 & 0 & 0 & 30,000 \\
\hline Scenario 8 & 39,500 & 7 & 5 & 10,000 \\
\hline Scneario C & 82,700 & 16 & 20 & 60,000 \\
\hline
\end{tabular}


energy developments in the four Corners states, while Scenario 0 assumed levels of energy development consistent only with a national mobilization on the scale of the Manhattan project. Scenarios 8 and $C$ assumed levels of Southwestern energy development intermediate to these two extremes. Scenario $B$ is further identified as a nuclear moritorium case.

Energy resource development facilities included in the Four Corners scenarios are total electrical generating capacity (megawatts), the number of synthetic "natural gas) (syngas) plants, the number of oil shale or synthetic crude oil (syncrude) plants, and the quantity of uranium ore mined and milled (tons), between 1975 and the year 2000. These projections, for five year intervals beginning in 1980, are shown in Tables 2.2 through 2.5 and Figures 2.1 through 2.4 for the Four Corners scenarios.

The scenario descriptions presented below contain two major components. First, the control totals used in the development of each scenario is identified. Then the assumptions made in regionally allocating energy development are presented. Discussion is facilitated by first examining the control totals used for each of the four scenarios and then discussing the electrical generating capacity projections included in the four scenarios.

\section{National Energy Scenarios As Control Totals}

Ronald Ridker and William Watson of Resources for the Future, Inc. have made long run (to year 2025) national projections based on alternative assumptions concerning population growth, labor force participation rates, productivity, unemployment, international developments, resource and enviornmental policy, agricultural export policy, style of living changes and technology. Table 2.6 summarizes the scenarios that have been considered by RfF and provides an indication of the range of the scenarios they have developed. In order to account for alternative national and international events, the final demands 
Table 2.2

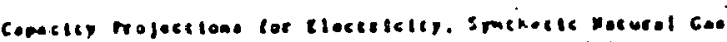

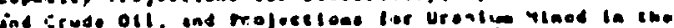
ious comecte sistes

scoserte.

\begin{tabular}{|c|c|c|c|c|}
\hline r... & 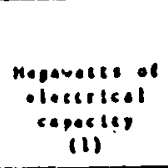 & 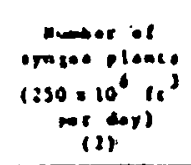 & 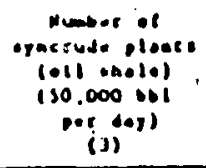 & 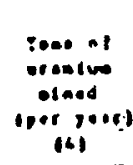 \\
\hline III) & 19.600 & 。 & 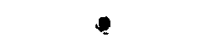 & 1.630 \\
\hline 1100 & 11.000 & 0 & • & 0.100 \\
\hline inis & 10.100 & 0 & . & 10.000 \\
\hline $18 \cdot 10$ & 32.200 & $n$ & . & 16.000 \\
\hline |a.11 & 1s.:Ac & 0 & 0 & 30 004 \\
\hline$\therefore x$ & $: 3.9: 0$ & 0 & , & 30,000 \\
\hline
\end{tabular}

\section{Table 2.4}

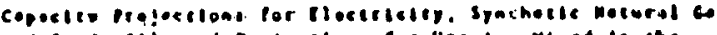

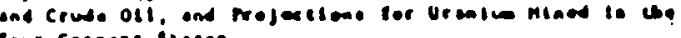

sconoriec

\begin{tabular}{|c|c|c|c|c|}
\hline reos & 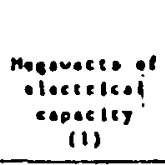 & 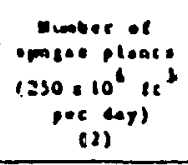 & 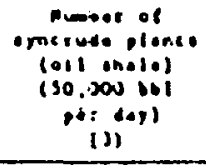 & 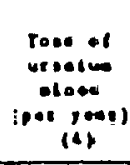 \\
\hline (n) & 13.600 & - & 0 & 6.610 \\
\hline 1100 & 21.000 & 0 & 0 & 1.230 \\
\hline (100) & 21.100 & , & 0 & 11.000 \\
\hline 1980 & 18.100 & - & - & 14.001 \\
\hline 1918 & 11,100 & 10 & 10 & 10,000 \\
\hline Yyon & 11.100 & 14 & :0 & +0.000 \\
\hline
\end{tabular}

Table 2.3

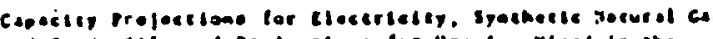

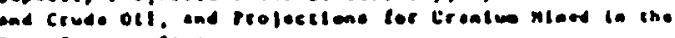

scenceste :

\begin{tabular}{|c|c|c|c|c|}
\hline roes & $\begin{array}{l}\text { Megevoccle of } \\
\text { - lescrical } \\
\text { capocilisy } \\
\text { (II) }\end{array}$ & 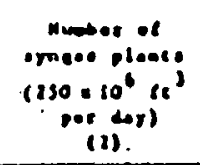 & 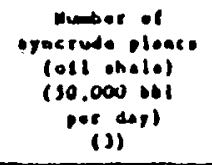 & 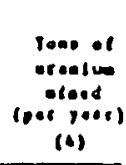 \\
\hline "!?!" & 19,400 & 0 & - & 0.410 \\
\hline 1100 & 11.900 & - & - & 1.390 \\
\hline 1919 & 21.100 & 1 & - & 12.000 \\
\hline 1110 & 20.300 & 2 & 0 & 16.000 \\
\hline 1918 & 31,400 & 3 & 1 & 21.000 \\
\hline 1000 & 11,500 & 1 & 1 & 10.000 \\
\hline
\end{tabular}

Table 2.5

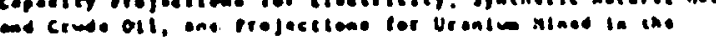

scouer 10 D

\begin{tabular}{|c|c|c|c|c|}
\hline Pe.er & $\begin{array}{c}\text { Mogavacse ol } \\
\text { olecsrical } \\
\text { capacily } \\
\text { (11) }\end{array}$ & 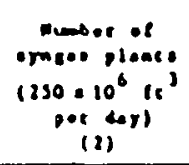 & 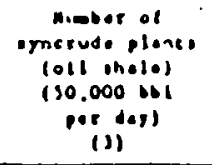 & $\begin{array}{c}\text { Sune of } \\
\text { urenive } \\
\text { elnet } \\
\text { (pee iaer) } \\
(a)\end{array}$ \\
\hline "111 & 13.100 & 0 & 0 & 0.410 \\
\hline 1100 & 21.000 & 0 & 0 & 1,380 \\
\hline (19) & מ.ו. & 3 & 26 & 11.000 \\
\hline 1990 & 32.000 & 11 & 46 & 36.000 \\
\hline$(19)$ & 13.300 & 32 & 31 & 30.000 \\
\hline \multirow[t]{2}{*}{$: 000$} & $104 .: \infty$ & 40 & $" 1$ & 00.000 \\
\hline & & $\dot{\square}$ &. & \\
\hline
\end{tabular}




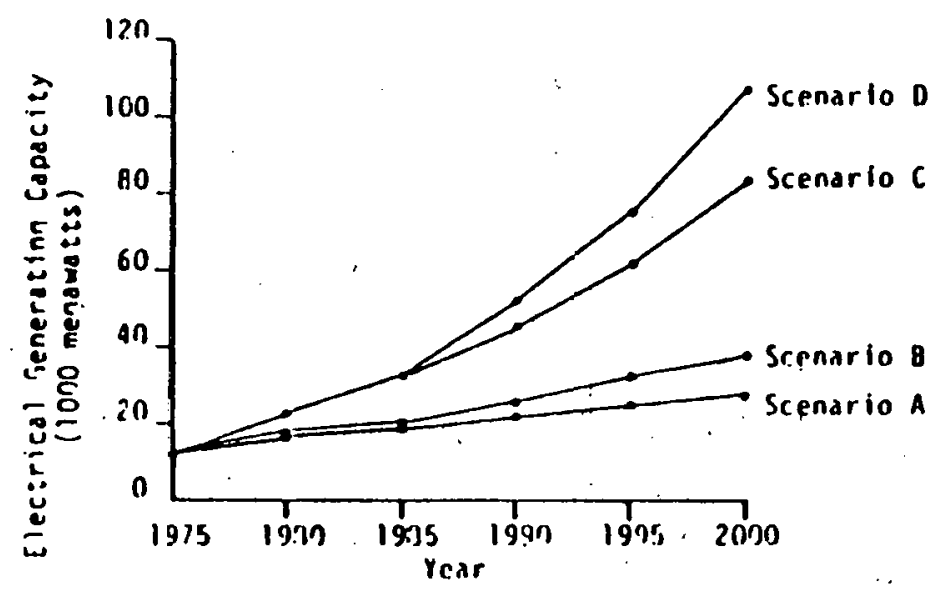

Finure 2.1 Clectrical romarating Capacity

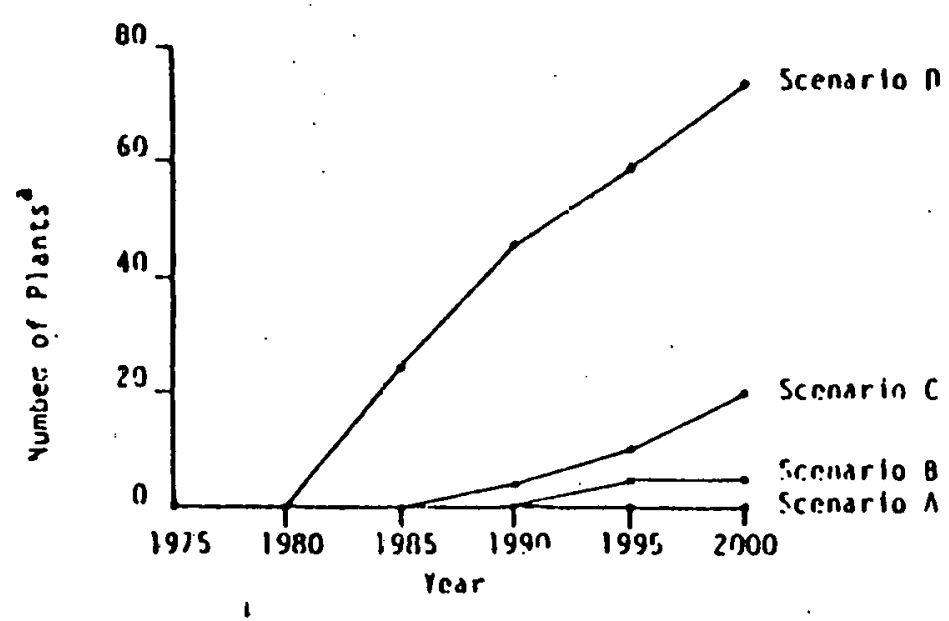

Fiqure 2.j Smehelle Crude OIII (Syncrude)

"standard plants of sn.000 bbl per day capacity

Figures 4-) Scenarlos for Electrical fienieratinn Capacity. Synthetic Natural rias (Syngas), Synihetlc Crude 011 (Syncrude). and Uranitam ilininn in the four Corners stales to the Year 2000

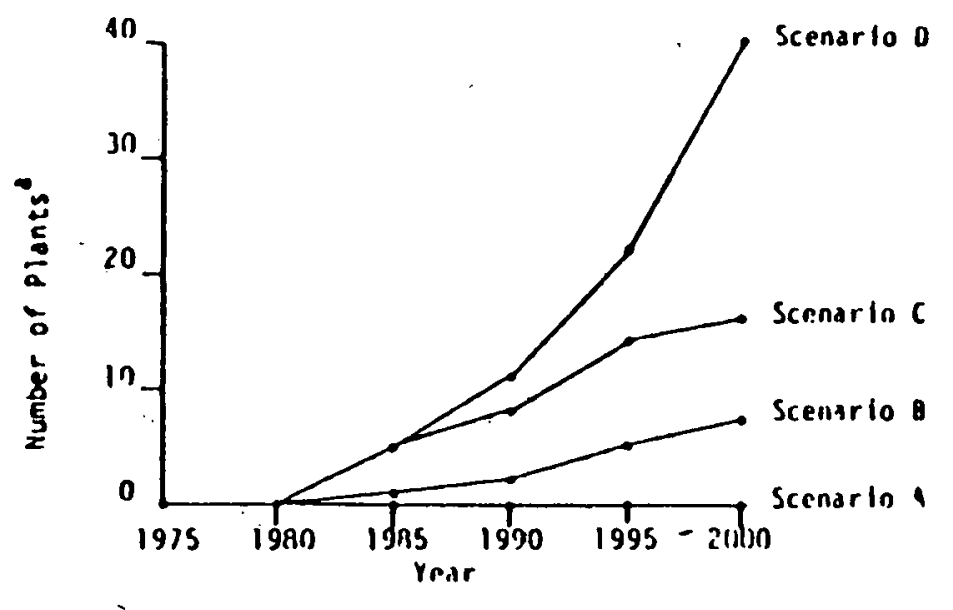

rinure 2.2 Synthetic Hatural rias (Synnas)

standara plants of 250 milliton cublc feet per day capaclity.

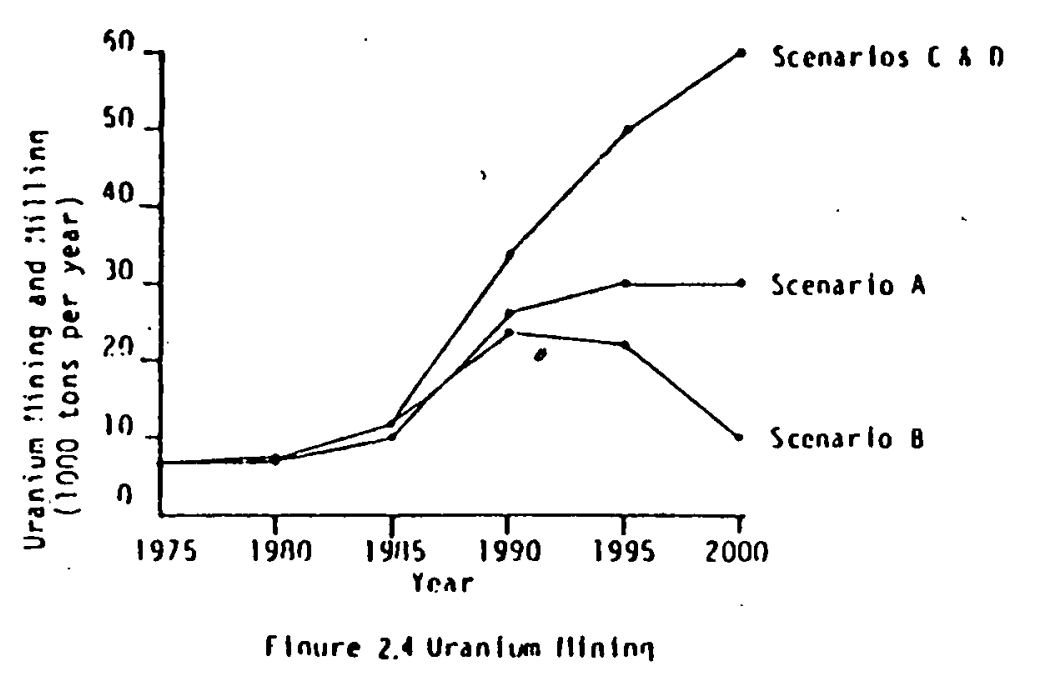


Table 2.6

MATIONAL SCEMARIOS

1 EXTRapolateo CASE:

II MOST OIFFICULT CASE:

III INTEROEPENDENT WORLD:

IY-A ACCELERATE RESOURCE SUPPLY TECHHOLOGIES:

IV-B ACCELERATE INTERMEDIATE EFFICIENCY:

IV-C HINIMIZE FINAL DEMANOS on RESOURCES:

$\checkmark$ EASE EMVIRONENTAL STAMDAROS

YI SLQWER ECONOMIC ANO POPULATION GROTH

III IHTEROEPENDENT, HIGH TECHOLOGY CASE:
This scenarto represents what is belleyed to be nost likely to occur given current trends; in other words. All dimensions extrapolated on the besis of best Judgement. This case will be run for high and lou populatinn and eronmente grourth.

In this case attempt to maxintze U.S. self-suffielency, maxlatze environental quility, maintain high population and economic growth, eurrent trends in technology, and maintain current styles of living.

This scenarto ilfes the import restrictions of Scenarto Il, while watutining all its other dimansions.

Thts scenarto is the same as Scenarlo II, except that technologles for finding. extracting and developing resources are eccelerated.

Thts scenarto is Identical to Scenarlo II, excep: that technologies for fuproving the effletency of conversion and/or utilization of resources ire dccelerated.

This scinario is lameical to Scenarto II, except that we consider technological changes meant to more effictently neet final dexands. (This is meant to be distinct from exogenous changes in styles of living. wich we will everitually put in as Seenarto VIII, but is not considered here because it does not mip us to classify tachnologica! changes, )

Thts scenarto allows comprowises wth enviromental quality. mile axidizing U.S. self-sufflctency, alintainting high econoante growth, current trends in technology, etc.

mis scanarto is identical to Scenarto II except for slower econoatc and population groweh.

This scenarto ecceierates all levels of technology while removing impore reserictions. Maxinum environmentes quality and high economic grourth are maintalned. In other words, it is combination of Scenarlos III and IY.

Source: Wlllian watson, Resources for the Future. Inc. 
for several of these projections were used as national control totals in the development of the Four Corners states scenarios.

Scenario A used national control totals from the "Extrapolated Case"

listed in Table 2,6. The specific assumptions made in the construction of this national scenario as described by Baxter and Evans (1977) are as follows:

"Bureau of the Census Series E population projections were used to make this national projection. Use of this series assumed that the recent downturn in fertility rates is a temporary phenomena, since the Series $E$ total fertility rate of 2.1 births per woman is above the current rate. It was also assumed that increases in female labor force participation rates and in the proportion of the population in working age aroups ( 16 to 64 years) would offset the downward trends in retirement age, working hours, and male participation rates. The economy returned to a 4 to $4 \frac{1}{2}$ percent unemployment rate by 1980, after which unemployment remained at this level. The rate of increase in productivity returned to its former, pre-recession level, but productivity itself shifted downward from its previous secular path in this national projection. International developments were taken into consideration by considering the relative prices of both oil and nonfuel minerals. It was assumed that solidarity within 0.P.E.C. would enable the maintenance of 1975 petroleum prices ( $\$ 12$ per barrel) in real terms for the next decade, at which time real prices would remain at this level because of demand pressure. In the case of nonfuel minerals, world reserves of nonfuel minerals were considered to be sufficiently dispersed geographically to avoid increases in real price caused by market cartelization. Resource policy considerations also centered around petroleum and rionfuel minerals. Petroleum and natural gas prices rose to the world level by 1985. No substantial effort was made. to increase domestic supplies or to dampen growth in demand. Hence, oil imports continued to fill the growing gap between domestic supply and demand. This same import assumption was followed in considering nonfuel mineral policies. The national "extrapolated case". allowed delays in implementing environmental standards for both automobiles and water pollution. Finally, it was conjectured that the U.S. Government would not permit agricultural exports to seriously affect domestic price."

Scenarios $C$ and $D$ used national control totals from the "most difficult

case". As described by Baxter and Evans (1977):

"... this set of projections placed maximum pressure on the United States resource base and at the same time minimized environmental side effects. Hence, a higher Bureau of the Census projection series (Series 0 ), which represents a 2.5 birth per woman tretal fertility rate, was used. Higher productivity rates were also assumed, as output per worker was extrapolated from the secular trend. Resource policy in the "most difficult case" assumed that a serious attempt would be made to reduce U.S. dependence upon foreign supplies. Under 
this set of assumptions, the Federal government intervened to stockpile petroleum and to insure the development of domestic substitutes with subsidy programs. Increased stockpiling was also a singificant ingredient of nonfuel minerals policy. Environmental reguiations were stringently enforced in the "most difficult case." Not only were clenaup timetables met, bur further, more demanding requirements were assumed to be met by the year 2000 . It was also assumed that foreign countires might experience setbacks in planned agricultural production, and that U.S. exports would be significant enough to exert upward price pressure on domestic consumers. Finally, the "most difficult case" was identical to the "extrapolated case" with regard to assumptions concerning labor force participation rates, unemployment rates, and international developments.

Scenario 8 used the RfF "Nuclear Moratorium" (not shown in Table 2.6) national control totals. This scenario is similar in all respects to the "most difficult case", except that no new nuclear power plants (except those elready planned) were allowed to come on line. Also, older plants were not replaced as they depreciated (Baxter-Evans, .1977).

\section{Electrical Generating Capacity}

The acceptance of industry planned energy facilities as the appropriate sequence for the development of energy resources, at least during the early stages of each scenario, has avoided unnecessary controversy. It may be argued that the industry is in perhaps the best position to predict the nature and scope of short term energy development in the region. And just as persuasively it may be argued that the planned development of a specific energy facility is likely to be significantly altered through the actions of environmental, regulatory, legislative or other special interest groups. Speculation concerning the accuracy of industry estimates of future development is thus not likely to be particularly constructive. A more reasonable approach, as employed in the scenarios pre- 
sented here, is to apply the industries planned facilities development in the sequence invisioned by the industry and simply label them as such.

The siting of energy facilities beyond the time frame covered by industry planning becomes speculative at best. The third principle listed.was designed to assure that the projections contained in the various scenarios are consistent with energy reserves estimated for fields to be exploited by the projected development. At the same time attention ias also given to the availability of water required for both the construction and operational stages of energy resource development. The resulting development sites projected to the year 2000 may thus be defended on the basis of both energy resource availability (a minimum of a thirty year supply for the energy facility) and water availability consistent. with the projected level of resource development.

Control totals for regional electrical generating capacity are based on the Western Systems Coordinating Council (WSCC) forecast incorporated in a reply (dated April 1976) to Federal Power Cormission Docket R0362. The WSCC is a regional electric reliability council representing the twelve western states. (Arizona, California, Colorado, Idaho, Montana, Nebraska, Nevada, New Mexico, Oregon, Utah, Washington and Wyoming). This forecast contains a chronological ordering of site-specific projections of new generating capacity from 1976 to 1985. This document also contains nonsite-specific projections of peak load for the period 1976 through 1995. A 5 percent growth rate was assumed for the period 1996 through 2000. This compares to the 5.8 percent average annual growth in peak load from 1976 to 1985 projected for the twelvestate region by WSCC.

Scenario 0 , the highest energy development series, uses the site-specific 
capacity expansion plans reported by WSCC to project increased capacity in the four southwestern states for the period 1976 to 1985 . These additions to electrical generating capacity are recorded in Table 2.7. It is then assumed that 50 percent of the increased capacity projected for the WSCC region from 1985 to the year 2000 will be located in the Four Corners states. This results in an average annual capacity growth rate of 7.8 percent in the four-state region during the period 1976 to the year 2000. In 1975 only 18.4 percent of the generating capacity in the twelve-state WISCC region was located in the four Corners states. Thus, scenario $D$ can be thought of as providing an approximate upper bound in additions to electrical generating capacity within the four Corners region. This scenario represents a strong shift toward minemouth generation of electricity in the Southwest for West Coast, Texas, and/or Midwest consumption (Sawyer, Brown and Abbey 1976).

Scenario $C$ also relies on site-specific capacity expansion plans reported by WSCC to project increased capacity in the Four Corners states in the period 1976 to 1985. Scenario $C$ assumes that 33 percent of the increase in capacity projected for the WSCC region from 1985 to the year 2000 will be located in the Four Corners states. These assumptions result in an average annual capacity growth rate of 6.75 percent in these four states for the period 1976 to the year 2000.

Scenario 8 assumes that electrical generation capacity will grow at a significantly lower annual rate than that suggested in WSCC forecast used in scenarios $C$ and $D$. Scenario $B$ assumes a 2 percent annual growth rate for the tweive-state WSCC region during the period 1976 to 1985 and a 3 percent annual growth rate for the region during the period 1985 to the year 2000 . The Four Corners states share of the total capacity additions of these twelve states is assumed to be equal to that reflected in the site-specific WSCC projections for 
Table 2.7. Planned Additions to Electrical Generating Cardcity in the Four Corners States

\begin{tabular}{|c|c|c|c|c|c|c|c|c|c|c|}
\hline Slole & 10 cods & Plent & tull 11 mo. & locettion & Cowity & Prion Miver & cop.. iw & Coner. & ivie & erianory Iuel \\
\hline Arlicuas & $\begin{array}{c}1 \\
0 \\
1 \\
: \\
9 \\
11 \\
12 \\
11 \\
11 \\
\text { is } \\
\text { int } \\
\text { in }\end{array}$ & 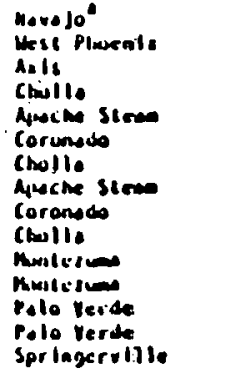 & 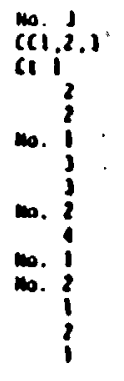 & 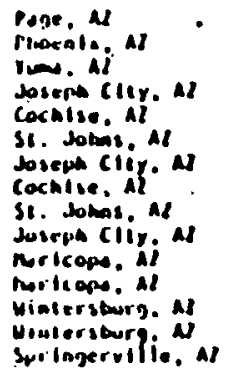 & 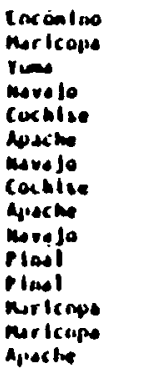 & 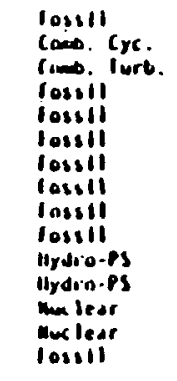 & 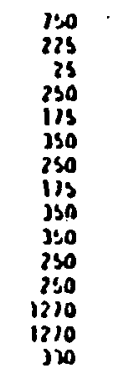 & 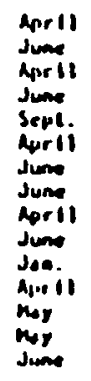 & 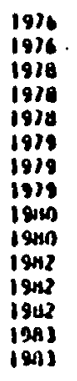 & 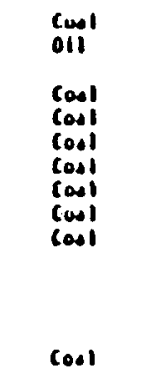 \\
\hline Color & 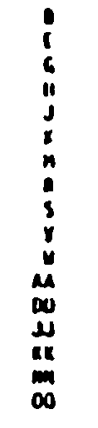 & 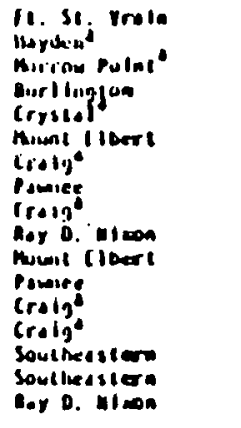 & $\begin{array}{r}i \\
i \\
i \\
i \\
i \\
i \\
i\end{array}$ & 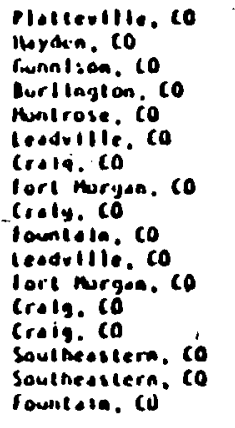 & 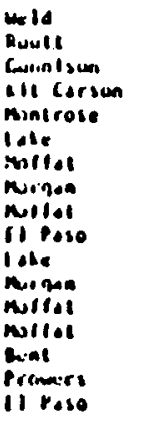 & 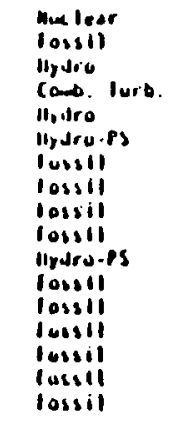 & 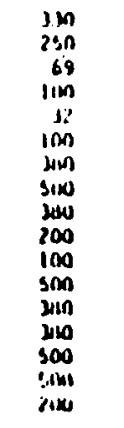 & 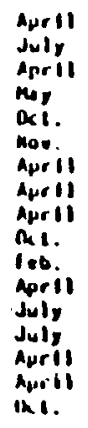 & 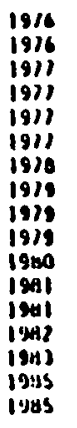 & 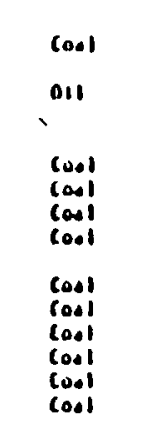 \\
\hline now Meilce & $\begin{array}{l}1 \\
1 \\
u \\
11 \\
11\end{array}$ & 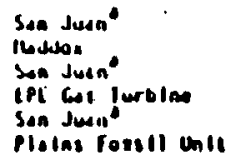 & $\begin{array}{l}\text { n. }\} \\
\text { no. } \\
\text { n. } 1\end{array}$ & 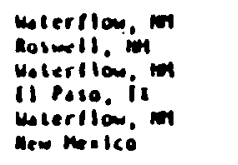 & 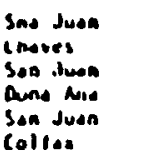 & 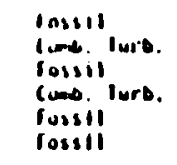 & $\begin{array}{l}100 \\
106 \\
166 \\
1160 \\
1180\end{array}$ & $\begin{array}{l}\text { Dee. } \\
\text { lune } \\
\text { wyy } \\
\text { Jume } \\
\text { nuy } \\
\text { Jan. }\end{array}$ & $\begin{array}{l}1916 \\
1916 \\
1916 \\
1919 \\
1941 \\
1981\end{array}$ & $\begin{array}{l}\text { Cost } \\
\text { Cas } \\
\text { Codil } \\
\text { Cool }\end{array}$ \\
\hline ulan & $\begin{array}{l}1 \\
0 \\
1 \\
i \\
1 \\
1 \\
1 \\
11 \\
11 \\
11 \\
11 \\
\text { of } \\
\text { ss }\end{array}$ & 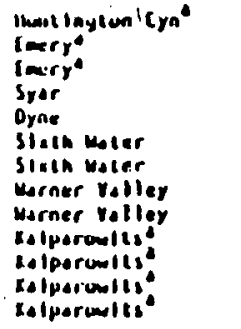 & $\begin{array}{l}1 \\
2 \\
1 \\
1 \\
1 \\
3 \\
1\end{array}$ & 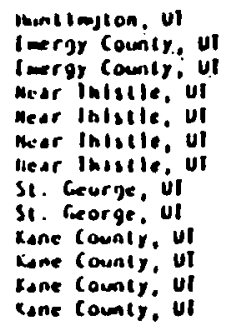 & 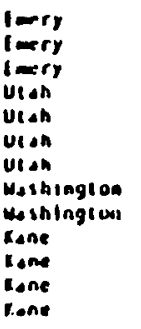 & 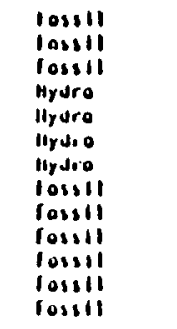 & 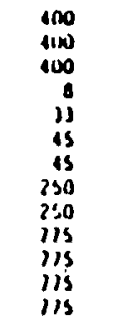 & 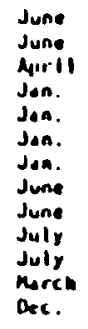 & $\begin{array}{l}1911 \\
1911 \\
1990 \\
1941 \\
1941 \\
1991 \\
19411 \\
1941 \\
19112 \\
1901 \\
1902 \\
1914 \\
1944\end{array}$ & 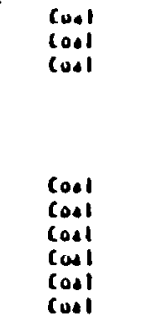 \\
\hline
\end{tabular}

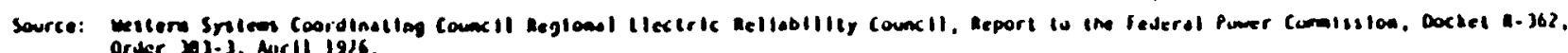


the period 1976 to 1985 and 33 percent of the increase in generating capacity projected for the period 1986 to the year 2000. These growth rates and geographic distribution of projected generating capacity results in an average annual growth rate of 3.75 percent for the four Corners states during the period 1976 to the year 2000.

The final scenario, scenario A, assumes a 2.5 percent annual growth rate in generating capacity in the four Corners states. This scenario can be interpreted as the minimum capacity expansion necessary to support the expected growth in population and electrical demand that will arise from within the four state region itself with no expansion in exports over the 1975 level. Thus this scenario may be said to provide a reasonable lower bound for additions to the region's generating capacity.

Although one conventional nuclear facility has commenced operation within the Four Corners region (a 320-MW facility at Platteville, Colorado), the figures for additions to electrical generating capacity recorded for each of the four scenarios are assumed to be all coal-fired facilities. This assumption recognizes the economic and environmental advantages of coal-fired facilities resulting from the very substantial, low cost, high quality coal reserves of the region. Table 2.8 summarizes the electrical generating capacity assumptions for the four scenarios. The approximate geographic location and chronological order of additions to electrical generating capacity are indicated in Figure 2.5. For this study the main interest was electrical generation from coal fired plants. To calculate this it was assumed that all capacity additions after 1975 are coal fired plants. The total generating capacities are given in Table 2.8. The percentages of coal, non-coal as a source of fuel is shown in Table 2.9. Coal fired generation is shown in Table 2.10. 
Figure 2.5 Additions To Electrical Generating Capacity

Aildlions A. B.... SS Mie hased on Western Systems Coordinaling

Cnuncil Iloninual fleciric Reliability Council.

Heport to llie rederal Power Commissinul, Docket

$R-362$. Order 3R3-J. (for the chronologica)

order of construction and size of Installatlon

see Iahle $\wedge-7$ ).

Auldtions 1,2,.. is Are loon thir additions to capacity numbered in

lle chronological order of projected constructinn.

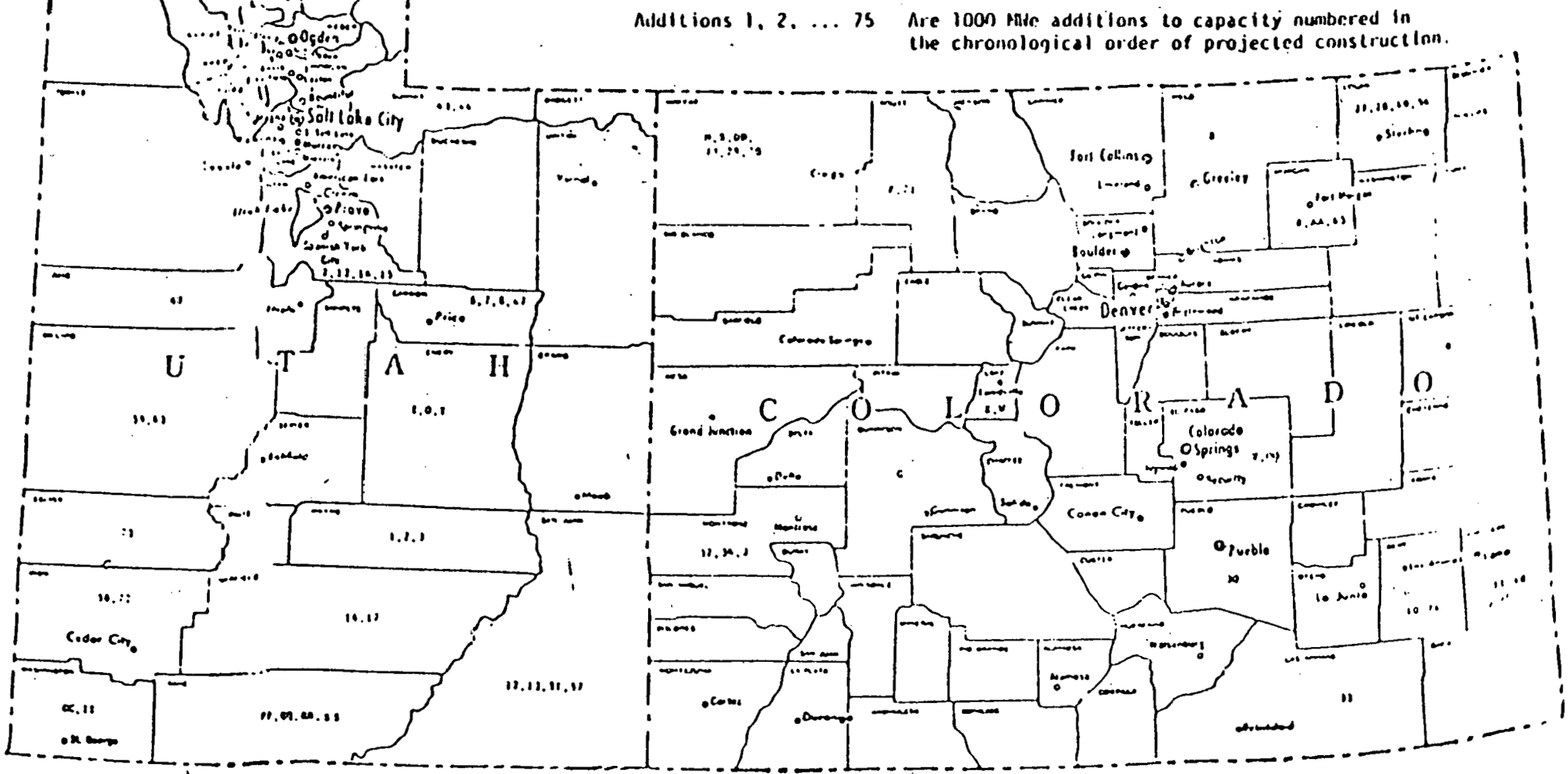

See footnotes on the following page 
Figure 2.5 (continued)

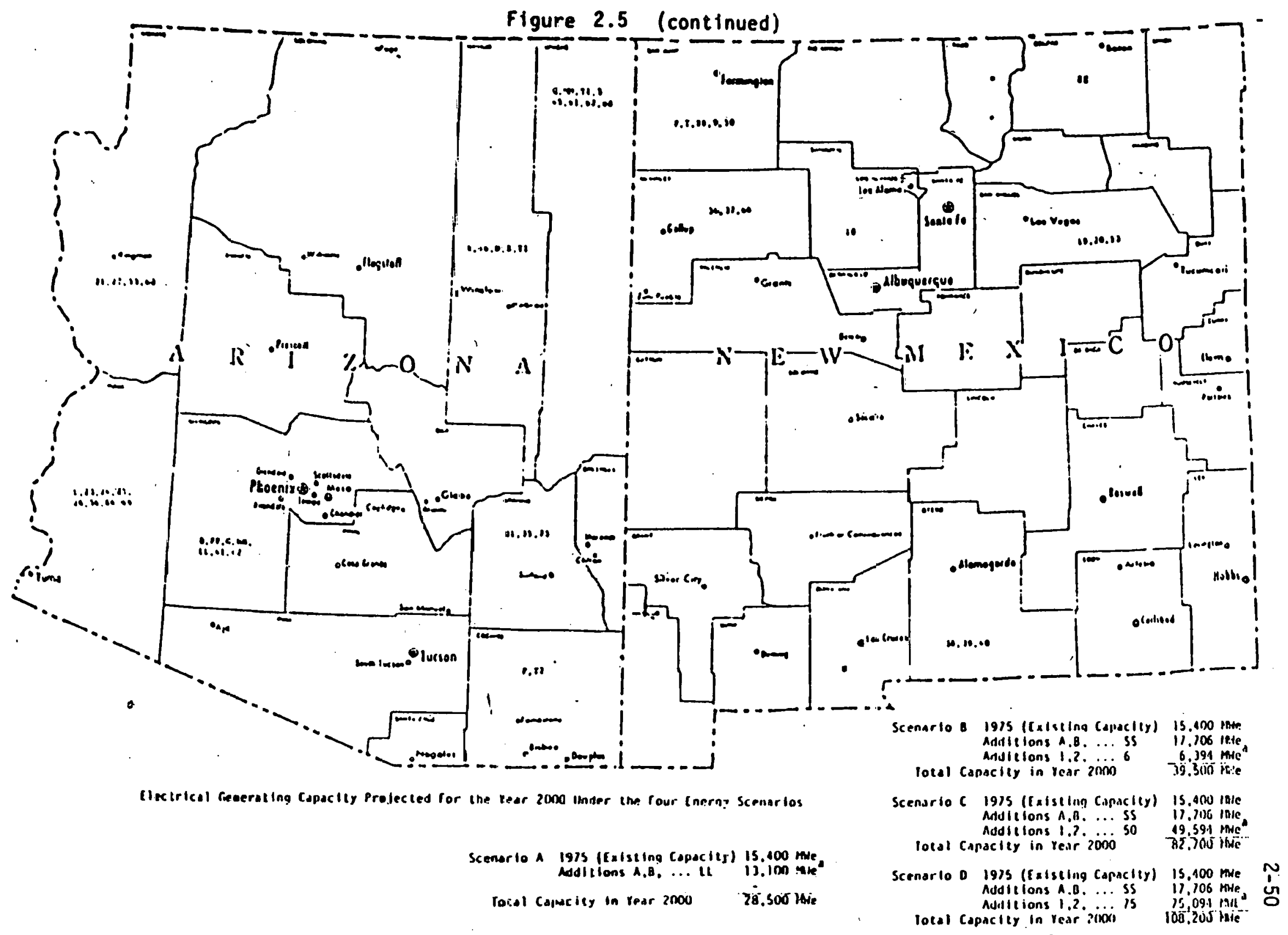

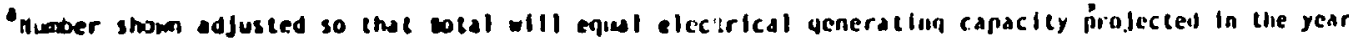
2000 for each scenario. 
Table 2.8 Electrical Generating Capacity

(Megawatts)

Scener 10 4

\begin{tabular}{|c|c|c|c|c|c|c|}
\hline seace & 1975 & 1480 & 1985 & 1940 & 1995 & 2000 \\
\hline Arisona & 6700 & $\because n n_{i}$ & $\$ 200$ & 9100 & 10000 & $\therefore: 00$ \\
\hline Colorsdo & 3700 & $\therefore=0$ & 5200 & 6200 & $: 100$ & sดว० \\
\hline ST : Lexico & 9900 & $6: 00$ & $\cdot 100$ & $\therefore 800$ & $\$ 300$ & 5600 \\
\hline leah & 1100 & 1100 & 1400 & 2100 & 2800 & 3000 \\
\hline Sal Tocal & $15=00$ & $:: \div 00$ & $: 9100$ & 22300 & $25: 00$ & $: 3500$ \\
\hline Us Tocal s & 3.000 & 582.000 & 860,000 & 992,000 & $: .131 .000$ & $1,275,000$ \\
\hline
\end{tabular}

Scenerte

\begin{tabular}{|c|c|c|c|c|c|c|}
\hline seace & 1975 & 1980 & 1983 & 1990 & 1995 & 2000 \\
\hline Arszom & 6700 & 1600 & 9100 & 11100 & $1: 800$ & 16700 \\
\hline Coloreso & 3700 & $6: 00$ & 5300 & 7200 & 8500 & 8700 \\
\hline Tow Mexico & 3990 & $:: 00$ & 3000 & $5: 00$ & 3200 & 5600 \\
\hline Vean & 1120 & 1500 & 2200 & 2800 & 5900 & 10700 \\
\hline SW Tocel & 13600 & 17900 & 21500 & $: 6300$ & $1:=00$ & 39500 \\
\hline us Tocal so & 05.000 & 793.200 & 999.000 & 1.203 .000 & $1,626,000$ & 1.660 .000 \\
\hline
\end{tabular}

sceners 6

\begin{tabular}{|c|c|c|c|c|c|c|}
\hline stece & 6975 & 1980 & 19es & 1990 & 1998 & 2000 \\
\hline Art2000 & 6700 & 9600 & $i 3000$ & $(5: 1) 0$ & 21000 & 26800 \\
\hline Coloreda & 3100 & 6300 & $i 600$ & 10100 & 12500 & 19600 \\
\hline Sav Mexice & 3900 & 6800 & $\$ 400$ & 6400 & 9600 & 15300 \\
\hline Veah & 1100 & 2300 & 6100 & 13100 & 18100 & 21000 \\
\hline su Toes & 13400 & 23000 & 13100 & 65600 & $71: 00$ & $12: 00$ \\
\hline us toent so & 15.000 & 793.000 & 999,000 & $1,: 05,000$ & $1,626,000$ & 1.660 .000 \\
\hline
\end{tabular}

Scener10 0

\begin{tabular}{|c|c|c|c|c|c|c|}
\hline seace & .2973 & 1900 & 1983 & 1990 & 1995 & 2000 \\
\hline Artsone & 6700 & 3000 & 13000 & . 18000 & $: 8100$ & 39000 \\
\hline Colorado & 3700 & 0300 & 9600 & 10600 & $17: 00$ & 20700 \\
\hline Nev Mezl<0 & 1900 & 4800 & 3400 & 1600 & 16000 & 17400 \\
\hline Leah & $1: 00$ & $: 200$ & 0100 & 13000 & 13100 & $": 7: 00$ \\
\hline sy Sotel & $43+00$ & : inan & ittuo & 52000 & 13509 & 104300 \\
\hline Us Torsl s & os, $1 \times 0$ & 993,000 & $199^{\circ}, 000$ & $1 .: 05.000$ & $1 . \therefore: 6.000$ & $\therefore .600,000$ \\
\hline
\end{tabular}


TABLE 2.9

SOURCE OF ENERGY FOR GENERATION OF ELECTRICAL POWER AS PERCENT OF TOTAL CAPACITY, 1974

\begin{tabular}{|c|c|c|c|c|}
\hline Fuel & Arizona & Colorado & New Mexico & Utah \\
\hline Coal & 25.6 & 55.2 & 63.7 & 68.3 \\
\hline Petroleum & 21.6 & 3.2 & 3.7 & 1.7 \\
\hline Natural Gas & 16.8 & 32.6 & 32.2 & 6.5 \\
\hline Hydro & 36.0 & 9.0 & 0.4 & 23.5 \\
\hline Nuclear & 0.0 & 0.0 & 0.0 & 0.0 \\
\hline $\begin{array}{l}\text { Total Percent } \\
\text { of Capacity }\end{array}$ & 100.0 & 100.0 & 100.0 & 100.0 \\
\hline Capacity (MW) & 6,349 & 3,673 & 4,069 & 1,224 \\
\hline
\end{tabular}

Source: Bureau of Mines Information Circular, Fuels and Energy Data: U.S. by States and Census Division for 1974. 
TABLE 2.10

COAL FIRED PLANT CAPACITY BY MW SCENAKIO A

AFI IZONA

COLOKALIO

NEW MEXICO

UTAH

ARI I ZONA

COLOKALIIO

NEW MEXICO

UTAH

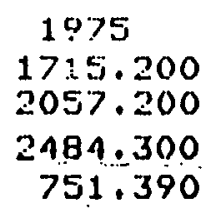

1980

2715.200

2757.200

.2784 .300

751.390
1990

4115.199

4657.199

3384.390
1751.300

1995

5015.189

5457.199

3864.390

2451.300

\section{SCENARIO F}

$1: 75$

1715.200

2057.200

2484.300

751.300

1980

2515.200

3057.200

2684.300

1151.300

1985

4115.179

3657.200

3584.390

1751.300
1990

6115.199

5557.199

3784.300

2451.390
1995

7815.199

6857.199

3784.300

5551.391
2000

7115.199

6357.199

3984.300

2651.300
AKIIZNA

COLOKAAIIO

NEW MEXICO

UTAH
1975

1715.200

2057.200

2404.300

751.300

1.95

ARIZONA

COLOFiAIIO

NEW MEXICO

UTAH

sTaF

TIHE 4 SECS.

$17: 5.200$

2057.200

2523.300

751.300

\section{SCENARIO C}

$\begin{array}{cc}1980 & 1985 \\ 4615.199 & 8015.289 \\ 4647.199 & 6957.199 \\ 3384.300 & 3984.300 \\ 1951.300 & 5751.301\end{array}$

1990

10115.199

9057.199

4984.301

1951.300

12751.301

1995

16015.199

10957.199

7984.301

17751.301

1985

4615.199

4657.199

3423.300

1951.300

1990

13015.199

8957.199

7023.301

14651.301
1995

23115.199

16057.198

13223.301

14751.301
2000

21815.199

17957.199

13834.301

20651.301

2000
37015.199
23057.199
16023.301
26751.301


SUMMARY AND CONCLUSIONS

It is emphasized that the scenarios described in this paper are not intended as predictions of future energy development, but merely illustrative possible levels of such development in the four state area. Further it is emphasized that no single scenario should be labeled the "probable" or "most likely" case. The uncertainty in the relevant political, and economic variables makes the forecasting of future energy resource development a very speculative exercise at best. It is suggested here that a useful alternative to such speculation is the examination of a range of possible levels of energy resource development presented will in many cases provide a useful base from which to examine a variety of economic, demographic, and environmental issues. 
Notes and References for Chapter 2

[1] Walther, Eric G., Predicted Transport of Air Pollutants from the Navajo and Kaiparowits Generating Stations into Lake Powell, Lake Powell Research Project Bulletin Number 26, August 1976.

[2] Roffman, H.K., Kary, R. E., and Hodgins, T., Ecological Distribution of Trace Elements Emitted by Coal-Burning Power Generating Units Utilizing Scrubbers and Electrostatic Precipitators, paper in Fourth Symposium on Coal Utilization (National Coal Association, 1977); as cited by J. J. Dvorak and B. G. Lewis, et al., in Impacts of CoalFired Power Plants on Fish, Wildlife, and The ir Habitats, a report prepared for the U. S. Fish and Widdife Service, March 1978.

[3] Radian Corporation, Coal-Fired Power Plant Trace Element Study, report prepared for U. S. Environmental Protection Agency, Region 8, Denver, Colorado, September 1975.

[4] Klein, D. H.; Andrea, A. W.; Carter, J. A.; Emery, J. F.; Feldman, C.; Fulkerson, W.; Lyon, W. S.; Ogle, J. C.; Talmi, T.; van Hook, I.; and Bolton, N., "Pathways for Thirty-Seven Trace Elements through Coal-Fired Power Plants," Environmental Science and Technology, September 1975.

[5.] Ondov, John M.; Ragaini, Richard D.; Bierman, Arthur H., "Elemental Emissions from a Coal-Fired Power Plant; Comparison of a Venturi Wet Scrubber System with a Cold-Side Electrostatic Precipitator," Environmental Science and Technology, May 1979.

[6] For a discussion of this project as it relates to the present work, see Appendix A to this chapter.

[7] Stanford Research Institute, Hazardous Wastes: A Risk-Benefit Framework Applied to Cadmium and Asbestos, report prepared for U. S. Environmental Protection Agency, 1977.

[8] Bonem, Gilbert and Mead, Richard, Future of the Non-Ferrous Metals Industry in the American Southwest (Project report to the Nationa Science Foundation under Grant No. AER-76-02378, January 1979).

[9] Lim, M. Y., Trace Elements from Coal Combustion-Atmospheric Emissions, Report No. ICTIS, TR05; IEA COal Research, London, England, May 1979.

[10] Goldberg, A. J., A Survey of Emissions and Controls for Hazardous and Other Pollutants, U. S. Environmental Protection Agency, 1973; as cited by Lim [9]. 
[11] U.S. Geological Survey, U. S. Forest Service Information "National Atlas of the United States of America - 1967 (1970).

[12] U.S. Department of Agriculture, Forest Service, "The Nation's Renewable Resources--An Assessment, 1975," Forest Service Report Number 21, U.S. Government Printing Office, Washington; D.C. (June 1977) p. 213.

[13] Ver Hosen, Isaac, et al., "Report of the Meteorology Work Group. Southwest Energy Study - Appendix E" National Oceanic and Atmospheric Administration, U.S. Department of Commerce, March 1972.

[14] Heffter, Jerome L., Taylor, Albion D. and Ferber, Gilbert J., "A Regional Continental Scale Transport, Diffusion and Deposition Model," NOAA Technical Memorandum ERL ARI.-50, June 1975.

[15] Fisher, B.E.A. and Maul, P. R., "The Mathematical.Modelling of the Transport of Sulfur Dioxide Across Country" presented at the Symposium "Systems and Models in Air and Water Pollution" organized by the Institute of Measurement and Control, London, 22-24 September 1976

[16] Nochumson, David H., "Models for the Long Distance Transport of Atmospheric Sulfur Oxides," Dissertation - Harvard University, January 1978.

[17] Pasguill, F., "Atmospheric Diffusion" (Halstead Press New York, New York, 1974) p. 260.

[18] Turner, D. B., "Workbook of Atmospheric Dispersion Estimates," USPHS Publication No. 999-AP-26, National Air Pollution Control Association, Cincinnati, Ohio.

[19] Jallouk; P. A., Kidd, G. G. Jr., and Shapiro, T., "Envi ronmental Aspects of Cooling Tower Operation: Survey of the Emission, Transport, and Deposition of Drift from the $K-21$ and K-33 Cooling Towers at URGDP," Oak Ridge Gaseous Diffusion Plant - Union Carbide Corporation Report No. K-1859, February 1974.

[20] Christianson, Gcnc, and Jacobson, Gerald A., "Report on Molybdenos is in Farm Animals and Its Relationship to a Uraniferous Lignite Ashing Plant," North Dakota State Department of Health, 1969.

[21] Personal communication with Phil Burangean, Universfty of Montana at Missoula, August 1979.

[22] Wangen, Lawrence E. and Williams, Michael D. "Elemental Deposition Duwnwind of a Coal-Fired Power Plant," Water, Air, and Soil Pollution, Volume IV (1978), pp. 33-44. 


\section{Chapter 3}

\section{Disposal of Waste Ash}

Trace elements from coal-fired power plants can enter the environment not only from atmospheric emissions but also from disposed of bottom ash and recovered fly ash. Ash disposal is the topic of this chapter, and the main environmental problems discussed involve contamination of groundwater and surface waters by disposed ash.

Trace elements enter power stations as constituents of coal. When coal is burned in the furnace, these elements become either fly ash particles or bottom ash particles. In the first form, they are emitted to the atmosphere or collected by electrostatic precipitators, wet scrubbers, or other collection devices. Both the collected fly ash and the furnace bottom ash are typically sent to an ash pond in a wet slurry. At a few power plants the ash may be placed in a landfill; also at a few locations, ash may be used for other products (such as mix for highway paving), disposed to mine sites, and a variety of other al ternatives.

Another way in which trace elements from power stations may enter ecological systems is from flue gas desulfurization wastes. Desulfurization units such as limestone scrubbers produce wastes that are usually sent in slurry to ponds or to landfills. This waste contains some amounts of trace elements that may enter the area environment.

Before discussing environmental pathways of trace elements in disposed bottom ash and fly ash, it is relevant to consider some quantitative dimensions of the problem. Consequently some estimates and 
projections of amounts of bottom ash and fly ash produced at coal-fired power stations are presented below. Also, estimates of amounts of land required for ash disposal and estimates of amounts of trace elements in the disposed wastes are presented. Because major interest in this report is on trace element problems in the Southwestern U. S.; the quantitative estinis presented below refer mainly to the Southwest.

Dvorak and Asscciates [1] have made the following estimates of bottom ash and fly ast: production rates for power stations using western coal:

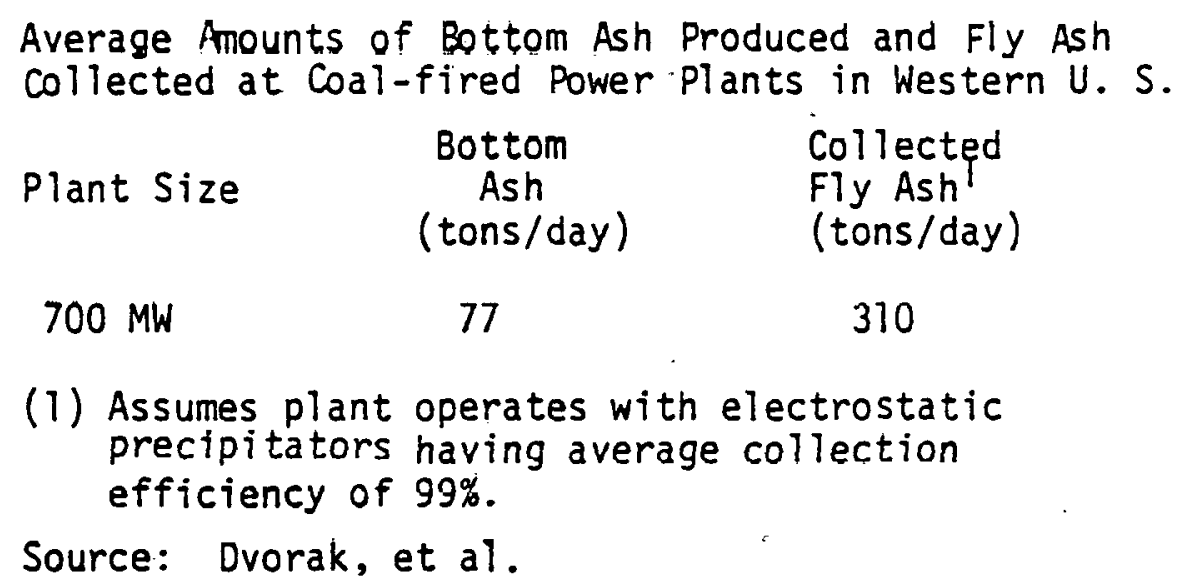

In the same report, there are estimates of the amounts of land required for ash disposal. The report assumes that ash is disposed in ponds which slowly fill and are then closed. Based upon the above ash production rates and assuming average pond depth of 10 feet, it is estimated that over a 40-year plant life, 195 acres would be required for ash disposal at a $700 \mathrm{MW}$ power plant.

These estimates of ash production and land requirements may be combined with estimates and projections of coal-fired generating capacity in the Southwest to produce estimates of total Southwest ash 
output and land use. As part of a detailed economic model developed at the University of New Mexico, estimates of amounts of coal-fired generating capacity were made [2]. These estimates and projections were mentioned in Chapter 2 , and it will be recalled that Scenario $B$ is a "medium" scenario. Projections from this case are:

Electrical Generating Capacity from Coal
Plants in the Southwest (MW), Scenario
Southwest Economic Model
\begin{tabular}{lrr} 
STATE & 1980 & 2000 \\
\hline STizona & 2620 & 9720 \\
Colorado & 3060 & 7060 \\
New Mexico. & 2680 & 3980 \\
Utah & 1150 & 10350 \\
\hline \multicolumn{1}{c}{ TOTAL } & 9510 & 31,110
\end{tabular}

- At the end of Chapter 2 atmospheric transfer coefficients were combined with Scenario D projections to obtain some "worst case" trace element effects. In the table that follows Scenario B projections are combined with estimates of ash production and land requirements to obtain "medium" estimates of ash output. These estimates yield some general magnitudes of solid waste output, "worst case" estimates would be higher.

Ash Production and Ash Disposal Land Requirements for Coal-Fired Power Plants in the Southwest

\begin{tabular}{lcrrrrr} 
State & $\begin{array}{c}\text { Bottom Ash } \\
\text { Production } \\
\text { (tons/day) }\end{array}$ & \multicolumn{2}{c}{$\begin{array}{c}\text { Fly Ash } \\
\text { Collected } \\
\text { (tons/day) }\end{array}$} & \multicolumn{2}{c}{$\begin{array}{c}\text { Land Require- } \\
\text { ments for Total } \\
40-y r \text { Plant Life } \\
\text { (Acres) }\end{array}$} \\
\hline Arizona & 1980 & 2000 & 1980 & 2000 & 1980 & 2000 \\
Colorado & 290 & 1070 & 1160 & 4310 & 730 & 2710 \\
New Mexico & 340 & 780 & 1350 & 3120 & 850 & 1960 \\
Utah & 190 & 440 & 1180 & 1760 & 740 & 1110 \\
\hline Total & 130 & 1140 & 510 & 4580 & 320 & 2880 \\
\hline
\end{tabular}


The last two columns of the preceding table need some clarification: the 1 and requirements for ash disposal for coal-fired power plants in 1980 means that if the plants producing at that time operate for 40 years, they will require 2,640 acres for ash disposal over the 40 year time period. By the year 2000 it is projected that electricity generation by coal-fired plants will be more than three times as làrge as in 1980, and the requirements of land for ash disposal by plants producing in year 2000 will total 8,660 acres over a 40-year life. Naturally, most of the plants producing power in 1980 will still be on-line in 2000 . Consequently, the 8,660 acres for year 2000 land requirements is not a "net" figure, rather it includes acreage for previously existing plants.

To obtain an idea of the dimension of waste disposal problems in the coal-electric power sector, it is also relevant to compare solid waste output of this industry with other industries. The following table, taken from an EPA publication [3], indicates that total solid wastes from coal-fired utilities are quite large:

\section{Quantity of Solid Residuals for}

Industry

$1970-74$

(10 $10^{6}$ tons/year, dry weight)

Food Processing

Textile Mill Products

Industrial Inorganic Chemicals

Industrial Organic Chemicals

Petroleum Refining

Blast Furnaces \& Steel Works

Coal-Fired Utilities

Total for All Industries
9.5

1.2

41.0

55.0

1.3 .0

9.2

43.0

260.0 
In this table only a selected number of industries are listed for purposes of making some comparisons. It is clear that volumes of waste from coal-fired utilities are quite large, and the EPA publication cited previously states:

"Total solid industrial waste residuals produced annually in the United States calculated from data covering the period 1970-74 amounted to 260 million tons per year.... Industrial organic chemicals, coal-fired utilities, and industrial inorganic chemicals are the largest contributors of residues and account for over half of the total production. The environmental impact of these residues has not received the attention which the volume of production would warrant."

Another way of obtaining an idea about magnitudes of ash disposal problems in the Southwest is to compare solid waste production from coal-fired power plants with that from Southwestern copper smelters and copper mines:

Solid Wastes from Southwestern Coal-Fired Power Plants, Copper Smelters and Copper Mines (tons/day)

From Southwest Coal-Fired

Power PTants 5,250

From Southwest Copper Smel ters 1 -

6,000

From Southwest Copper Mines? 720,000

I/Based on data prepared by Bonem and Mead [4]. Slag is the primary solid residue coming from copper smelters.

2/Based on data prepared by Bonem and Mead. "Solid Waste" from mines includes overburden, waste rock, and tailings. 
The solid wastes from copper mines include the very large amounts of mine overburden and waste rock that must be disposed. Indeed, a correct comparison of solid waste disposal problems would compare volumes of wastes from coal mines (that feed coal-fired power plants) with those coming from copper mines.

The yolume of solid wastes from coal-fired power plants in the Southwest is about equal to that of Southwestern copper smelters. These two industries are probably the largest generators of solid waste in the Southwest although iron and steel works in Utah and Colorado are also significant contributors. It is yery likely that electricity generation via coal will grow more rapidly in the Southwest than copper, and the combined coal mining-coal preparation-coal electric power complex will become the region's foremost generator of solid waste.

A further dimension to the problem involves disposal of solid wastes by flue gas desulfurization units such as limestone scrubbers. In the future, Southwestern coal-fired plants are likely to be required to install desulfurization units, and this will increase the output of solid wastes by significant amounts. As cited above, Dyorak and associates estimate production of bottom ash and collected fly ash at a $700 \mathrm{Mw}$ western power plant to be about 390 tons per day. The addition of a flue gas desulfurization unit is likely to almost double this output of solid wastes.

As a final note, we present some very tentative calculations of amounts of trace elements in disposed ash from power plants. Based upon data in the engineering literature (see Table 1 below), it was estimated that the following amounts of selected trace metals would be in disposed 
ash for the Southwest region in 1980:

\begin{tabular}{lc} 
& $\begin{array}{c}\text { Amounts of Elements } \\
\text { in Disposed Ash } \\
\text { for Entire Southwest Region } \\
\text { (1bs/day) }\end{array}$ \\
\hline Arsenic & 190 \\
Cadmium & 70 \\
Chromium & 4560 \\
Copper & 6290 \\
Lead & 2280 \\
Selenium & 360 \\
\hline
\end{tabular}

Total bottom ash and collected fiy ash produced at

Southwestern coal-fired power plants, 1980: 5,250 tons/day.

There are, of course, other trace elements in significant amounts; the six metals above were selected for purposes of illustration. It is important to mention that these estimates of trace element outputs are based upon estimates of trace element ash content found in the engineering literature. Actual outputs could deviate from these estimates by wide amounts because of regional variation in coal mineralization, variation in plant furnaces, and a number of other factors.

Hopefully the preceding data indicate some important aspects of the problem of trace element emissions from power plant wastes. Attention is now turned to the ways that the trace elements in disposed ash enter ecological systems. 
There are several ways that trace elements in bottom ash, fly ash, and gas desulfurization wastes can enter environmental systems:

(1) Usually these wastes are sent to an ash pond, and the most important path from the pond involves leaching of trace metals to the soil-groundwater complex. Trace metals in pond leachate may impair groundwater quality and may also be retained in surface soil for extended periuds of time.

(2) Surface water (Takes, rivers, and springs) may be connected with area groundwater, and trace elements that are seeped to the water tạble may eventually contaminato surface waters.

(3) When disposal ponds are filled and closed, leaching of trace metals to groundwater may continue. Moreover, surface soils might be too contaminated for growth of vegetation. Problems with trace elements may continue for a considerable period after the electricity plant is closed.

(4) When fly ash, bottom ash or ponded solids are placed in landfills, the same problems are likely to occur: trace elements may leach from the landfill to the soil and water table. From the water table, efilry uf these elefienes to area surface waters is a possibility. Once again, trace elements transported in the soil may damage vegetation and, eventually, wildife. In attempting to assess the economic damages resulting from trace elements in disposed bottom ash, fly ash, and desulfurization waste, it is necessary to know (1) the pathways through which these elements affect the environment; (2) the quantities of trace elements involved; (3) the responses of human, animal, and plant ijfe to doses of these 
elements. In this section, interest is on assessing the capability of scientists and engineers to make fairly accurate statements about the first two topics. That is, what is our present scientific capability" for making statements about quantities of trace metals disposed to ash ponds? What is our present capability for making statements about quantities of trace metals leached to the water table? What capability exists for making statements about groundwater--surface water interrelationships? The third topic mentioned (responses of plants, animals, and humans to doses of trace elements) is covered in the next chapter. Finally, in this section, means of reducing the environmental impact of trace elements in disposed ash are discussed, and there is discussion of the costs of these al ternatives.

The quantity of trace elements that enters a power station with coal must equal the quantities that are emitted and disposed. Thus, a decrease in atmospheric emissions of trace metals necessarily implies an increase in the amounts disposed to ash ponds and landfills. Present knowledge about amounts of trace elements in input coal and power station emissions appears to be fairly reliable. Inputs and outputs of these elements will vary by region; and also, within regions, there may be noticeable variation in trace element content of coal. Nonetheless, somewhat reliable statements can be made about inputs and outputs

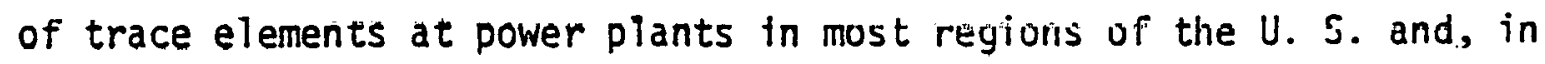
particular, for areas in the Southwestern U. S.

Table 1 is an example of the kind of data availuble (Radian Corp [5] and Klein [6]). The table shows the quantities of trace metals in input coal, bottom ash, collected fly ash, and outlet flue gas for 
two power stations. Three comments about the table may be helpful:

(1) The Tennessee station has capacity of $290 \mathrm{Mw}$ and operates with an electrostatic precipitator with average ash collection efficiency of $99 \%$.

(2) The data for "Radian" Station 1 refer to a power station in the Rocky Mountain region using a Wyoming coal and having capacity of $330 \mathrm{Mw}$. This power station has wet scrubbers with average fly ash collection efficiency of $99 \%$.

(3) Theoretically, the amount of trace metals in input coal should equal the trace metal outputs in bottom ash, collected fly ash, and atmospheric discharge (mass balance). Actually, because of measurement errors, inputs of trace metals from other sources (e.g., I1me for combustion chamber), and outputs to other sources (e.g., fugitive emissions) there is frequently imbalance in the reported data.

Table 1 indicates that when power stations have high efficiency precipitators or scrubbers most of the trace metals in the input coal will be disposed to ash ponds.

In discussing the input and output of trace elements from a power station, an item of some interest is the partitioning of elements between bottom ash and fly ash. In the combustion of coal some elements tend to enter the fly ash going to the stack and other elements are more frequently found in bottom ash. Klein and associates have proposed 'the following classification:

Class I elements: These elements are not violatilized in the combustion zone but tend to form a uniform melt that becomes 


\section{TABLE 1}

TRACE ELEMENTS FLOWS IN COAL-FIRED POWER PLANTS

\begin{tabular}{|c|c|c|c|c|c|c|c|c|}
\hline \multirow[b]{2}{*}{ Substancé } & \multirow[b]{2}{*}{ Coal } & \multicolumn{2}{|c|}{$\begin{array}{c}\text { Tennessee Plant } \\
(\mathrm{g} / \mathrm{min} .)\end{array}$} & \multirow[b]{2}{*}{$\begin{array}{l}\text { Atmospheric } \\
\text { Discharge }\end{array}$} & \multirow[b]{2}{*}{ Coal } & \multicolumn{2}{|c|}{$\begin{array}{c}\text { Radian Station } 1 \\
\text { (Ibs./hour) }\end{array}$} & \multirow[b]{2}{*}{$\begin{array}{c}\text { Atmospheric } \\
\text { Discharge }\end{array}$} \\
\hline & & Slag & $\begin{array}{l}\text { Inlet } \\
\text { fly Ash }\end{array}$ & & & $\begin{array}{c}\text { Bottom } \\
\text { Ash }\end{array}$ & $\begin{array}{l}\text { Scrubber } \\
\text { Recovery }\end{array}$ & \\
\hline Aluminum & 14,000 & 10,400 & 3,600 & 400 & 6509 & 1188 & 5400 & 16.5 \\
\hline Arsenic & 5.3 & .5 & 1.8 & .2 & .23 & .015 & .26 & .021 \\
\hline Barium & 96 & 42 & 55 & .3 & 37 & 7.7 & 44 & .41 \\
\hline Cadmium & .58 & .42 & .30 & .01 & .051 & .012 & .09 & .0078 \\
\hline Cobalt & 4.9 & 2.7 & 2.1 & .04 & .59 & .081 & .41 & .013 \\
\hline Chromium & 27.5 & 21.2 & 14.0 & - & 5.9 & .77 & -5.9 & .76 \\
\hline Copper & 12.2 & 1.7 & 10.3 & - & 9.6 & 1.1 & 8.0 & .06 \\
\hline Mercury & .18 & .002 & $.17^{\star}$ & .1 & .04 & .0002 & .003 & .02 \\
\hline Manganese & 66 & 56 & 18 & .8 & 48 & 8.0 & 50 & .22 \\
\hline Nickel & 23 & 7 & 16 & - & 2.5 & .45 & 2.5 & .10 \\
\hline Lead & 9.2 & .6 & 7.8 & .2 & 1.2 & .08 & 2.5 & .05 \\
\hline Antimony & .74 & .05 & .89 & .2 & .15 & .0045 & .12 & .0017 \\
\hline Seleniun. & 3.2 & - & $2.3^{\star}$ & .4 & .62 & .05 & .44 & .02 \\
\hline Titanium & 680 & 390 & 230 & 6 & 311 & 52 & 200 & .79 \\
\hline Uranium & 3.0 & 2.0 & 1.1 & .02 & .37 & .15 & .21 & .006 \\
\hline Vanadium & 46 & 34 & 23 & .8 & 14 & 2.8 & 13 & .4 \\
\hline Zinc & 120 & 3 & 78 & 2 & .23 & .03 & .16 & .0012 \\
\hline Beryllium & & & & & .23 & .029 & .16 & .0012 \\
\hline Fluorine & - & & & & 40 & 22 & 40 & .85 \\
\hline
\end{tabular}


both fly ash and bottom ash. Elements in this category enter fly ash and bottom ash in about equal amounts (a) though there is considerable variation). Elements in this category include $\mathrm{Al}, \mathrm{Ba}, \mathrm{Fe}, \mathrm{Mn}, \mathrm{Co}$, and Ti..

Class II elements: These elements appear to be volatilized in the combustion zone and become absorbed on small particles in the fly ash. Thus, these elements preferentially enter stack fly ash. Elements in this category include $\mathrm{As}, \mathrm{Cd}, \mathrm{Cu}, \mathrm{Pb}, \mathrm{Sb}$, $\mathrm{Se}$, and $\mathrm{Zn}$.

Class III elements: In the combustion chamber these elements go into gas phase and remain in that phase. Also, they enter the stack in gas phase. Elements in this category include $\mathrm{Hg}, \mathrm{Cl}$, and $\mathrm{Br}$.

Although this classification scheme of partitioning of trace elements is interesting, it must be noted that recently constructed power plants with high efficiency precipitators or scrubbers will collect most of the fly ash and dispose it to ash ponds and/or landfills. From ash ponds, the environmental paths of trace elements are to soil and to groundwater. Basically, once trace elements have reached the ash pond there are three paths they may pursue:

(1) trace elements may precipitate from pond slurry onto the pond bottom and remain there in insoluble form;

(2) they may be leached to soil beneath the pond with the additional possibility of transportation throughout adiacent soils;

(3) they may be leached further and reach the groundwater table. In the preceding paragraphs it was indicated that in the technical 
literature there are quite a number of estimates of trace metal quantities in bottom ash and fly ash disposed to ponds. In addition, there are some estimates of the amounts of trace elements in ash pond surface water. For example, Dressen, Gladney, et al. [7] have indicated the trace metal concentrations of the ash pond at the Four Corners Generating Station, New Mexico. The data collected et al are shown in Table 2. In this table the trace element concentrations in water from an adjacent stream (the San ulan River) are also given. Comparison of the first and third columns of Tajle 2 indicates that the elements that become most concentrated in pond waters are arsenic, boron, iron, molybdenum, selenium, and vanadium. Coal used at the power station contains all of these in significant amounts. From other sources in the literature, additional data can be obtained about amounts of trace elements in ash pond water. The important aspect, however, involves the paths that those elements follow from the pond, and the most important path involves leaching to the soil and to the water table. In the Southwest, ash ponds are usually not drained to rivers or lakes. Rather, decanted water is recycled to the plant and some pond water is lost through evaporation. Water recycled to the plant is used for sluicing additional bottom ash to the pond or for cooling. In either case, it is eventually ponded in an ash pond or an existing pond, and the main environmental path from the pond involves leaching to the soil.

The search that we conducted for literature aboit quantities of trace metals leached from ash ponds indicates that there is little hard data available. There is a significant amount of qualitative 
TABLE 2

TRACE ELEMENT CONTRATIONS IN ASH POND WATERS,

FOUR CORNERS GENERATING STATION.

FRUITLAND, NEW MEXICO

\section{Ash Pond \\ Surface Water \\ (ppb)}

Ash Pond.

Effluent

(ppb)
Cooling Lake Intake

(from San Juan. River) (ppb)

\begin{tabular}{lrrr}
\hline Arsenic & 33 & 27 & 2.6 \\
Boron & 17,000 & 12,000 & $<100$ \\
Beryllium & $<.2$ & $<.2$ & $<.2$ \\
Cadmium & 1 & 1 & 1 \\
Chromium & 3 & 2 & $<1$ \\
Copper & 2 & 3 & 3 \\
Iron & $n .2$. & 16,000 & 220 \\
Molybdenum & 160 & 170 & $<1$ \\
Selenium & 60 & 57 & $<1$ \\
Vanadium & 140 & 130 & 2 \\
Zinc & 580 & 440 & 590 \\
\hline
\end{tabular}

Source: Dressen, Gladney, Owens, Perkins, Wienke, and Wangen, "Comparison of Levels of Trace Elements Extracted from Fly Ash and Levels Found in Effluent Waters from a Coal-Fired Power Plant," Environmental Science and Technology, October 1977. 
information and judgment about leaching of heavy metals in the literature, but quantitative data on this topic are incomplete and tentative. The following notes cover the most important points in the literature:

1. Soils have attentuation capacity for holding trace elements, i.e., as pond leachate moves into the soll some trace elements will be removed before they reach the water table. The attentuation capacity of a soil depends on a number of factors including soil porosity; for example, sandy soils have less attentuation capacity than soils with a clay base.

2. Over long periods of time trace elements are more likely to leach to the water table than during short time periods. Trace elements build up in the soil over long time periods; the ability of soil to hold additional amounts of these decreases; and transport to deeper levels occurs. Holland, et a1. [8] performed laboratory studies of trace element leaching from ash and scrubber sludges. Based upon laboratory tests, the following table concerning soil attentuation capacity over time was prepared. Holland's table shows that leaching of trace elements to the water table is more likely to occur during long time frames than during short ones. Moreover, the table indicates that the elements least susceptible to soil attentuation and most likely to reach the water table are chromium, fluorine, selenium, and mercury.

3. An important note is that trace elements leached from the pond but not reaching the water table remain in the soil. This may present problems if there are future attempts to reclaim and revegetate ash ponds after closure of the power plant. Moreover, trace elements 
TABLE 3

TABLES FOR DETERMINING APPROXIMATE VERTICAL DEPTH REQUIRED FOR REDUCTION OF TRACE-ELEMENT LEVELS TO LESS THAN $5 \%$ OF THE POND CONCENTRATIONA

\begin{tabular}{|c|c|c|c|c|c|c|c|c|c|c|}
\hline \multirow{2}{*}{$\begin{array}{c}\text { In'sofls } \\
\text { similar to } \\
\text { station no. }\end{array}$} & \multicolumn{5}{|c|}{ Depen (m) required - dsh leachase, } & \multicolumn{5}{|c|}{ Depen (m) required - sludge leachace } \\
\hline & Arsenic & Chromium & Copper & Fluorine & Selentum & Chromiuna. & Copper & Fluorine & Mereury & Zine \\
\hline \multicolumn{11}{|c|}{ After two years } \\
\hline 1 & $<4.9$ & 60 & $\therefore . ?$ & 610 & 37 & 60 & 0.9 & 60 & 21 & 0.9 \\
\hline 3 & $<2.7$ & 2.7 & $\therefore ?$ & .15 & 3 & 18 & -1.2 & 10 & c1.2 & 51.2 \\
\hline 4 & $\therefore .2$ & 2.1 & $\therefore . \therefore$ & 21 & 5.2 & 17 & 0.9 & 24 & 1.5 & 0.9 \\
\hline 5 & $<2.1$ & $>30$ & $\because \ldots$ & 229 & 4.6 & 29 & .0 .9 & 29 & -81.2 & $<1.2$ \\
\hline \multicolumn{11}{|c|}{ After cen years } \\
\hline 1 & .15 & 215 & $<15$ & 3.050 & 150 & 305 & 3 & 305. & 130 & 4.9 \\
\hline 3 & $<10$ & 10 & .10 & $: 85$ & 11 & 88 & .5 .8 & 49 & 25.8 & c9.8 \\
\hline 4 & .3 .4 & $?$ & $<3.4$ & $\$ 110$ & 19 & 67 & 3 & 94 & 4.5 & <3. \\
\hline & & & N. O. & 120 & 16 & 170 & 23 & 170 & 3.7 & 3.7 \\
\hline \multicolumn{11}{|c|}{ Sn-100 yeors } \\
\hline 1 & $\checkmark 150$ & 2.285 & .150 & 30,480 & 1.555 & 305 & 27 & 3.050 & 1.220 & 37 \\
\hline 3 & 479 & $\begin{array}{l}79 \\
55\end{array}$ & $\begin{array}{r}79 \\
23\end{array}$ & 2855 & 85 & $\begin{array}{l}855 \\
670\end{array}$ & 499 & 425 & .49 & 89 \\
\hline 5 & 258 & 1.280 & n.o. & $\begin{array}{l}7.61 \\
1.130\end{array}$ & 70 & 1,280 & 24 & 1.280 & 26 & 2.6 \\
\hline
\end{tabular}

(a) Source: Holland, et al.

(b) Notes on soil type: Station 1
Station 2
Station 3
Station 4
Station 5 Average Permeability (cmls) $5.1 \times 10-4$ $5 \times 10-8$ $7.4 \times 10-6$ $1.2 \times 10-5$ $2.1 \times 10-5$

remaining in upper soil layers might be transported in a wider soil area and affect vegetation near the pond.

4. Perhaps the most complete study of leaching of trace elements from power station ash ponds is that done by Theis and associates [9]. The most important points in their study are:

-- The pH of the pond will affect the amount of trace elements that leach to the water table. High $\mathrm{pH}$ tends to cause trace metals to precipitate from solution and remain at the bottom of the pond. Trace metals are more soluble in ponds with significant acidity, and larger quantities of these will leach to the water table. 
-- Complexes of iron and managanese oxides in soils appear to be the main "sinks" for heavy metals leached from ash ponds.

Particles of chromium, arsenic, lead, etc., tend to be absorbed onto particles of iron and manganese oxides in the soil. Thus, volumes of the latter are important in determining soil attentuation capacity.

-- Theis and his associates use a chemical - aquatic equilibrium model to predict trace element concentrations in the soil and in the soil-groundwater complex. The predictions of the model are quite close to actual concentrations, and future modeling work on trace element leaching might well use the same model.

-- The following table shows metal concentration in pond leachate as a function of distance from the pond:

Distance.

TRACE METAL CONCENTRATIONS OF LEACHATE $(\mu g / 1)$

from Pond

(meters)

Arsenic

Iron

Lead

Chromium

0

5000

3500

120

25

20

25

200

80

5

200

50

2800

260

20

400

20

5000

120

5

Although amounts of trace elements in the leachate fluctuate, the general pattern is a decline with increasing distance from the pond. This is more clear in the articles prepared by Theis and his associates. 
An attempt to summarize our ideas about impacts of trace metals in solid-liquid wastes may be based on the following diagram:

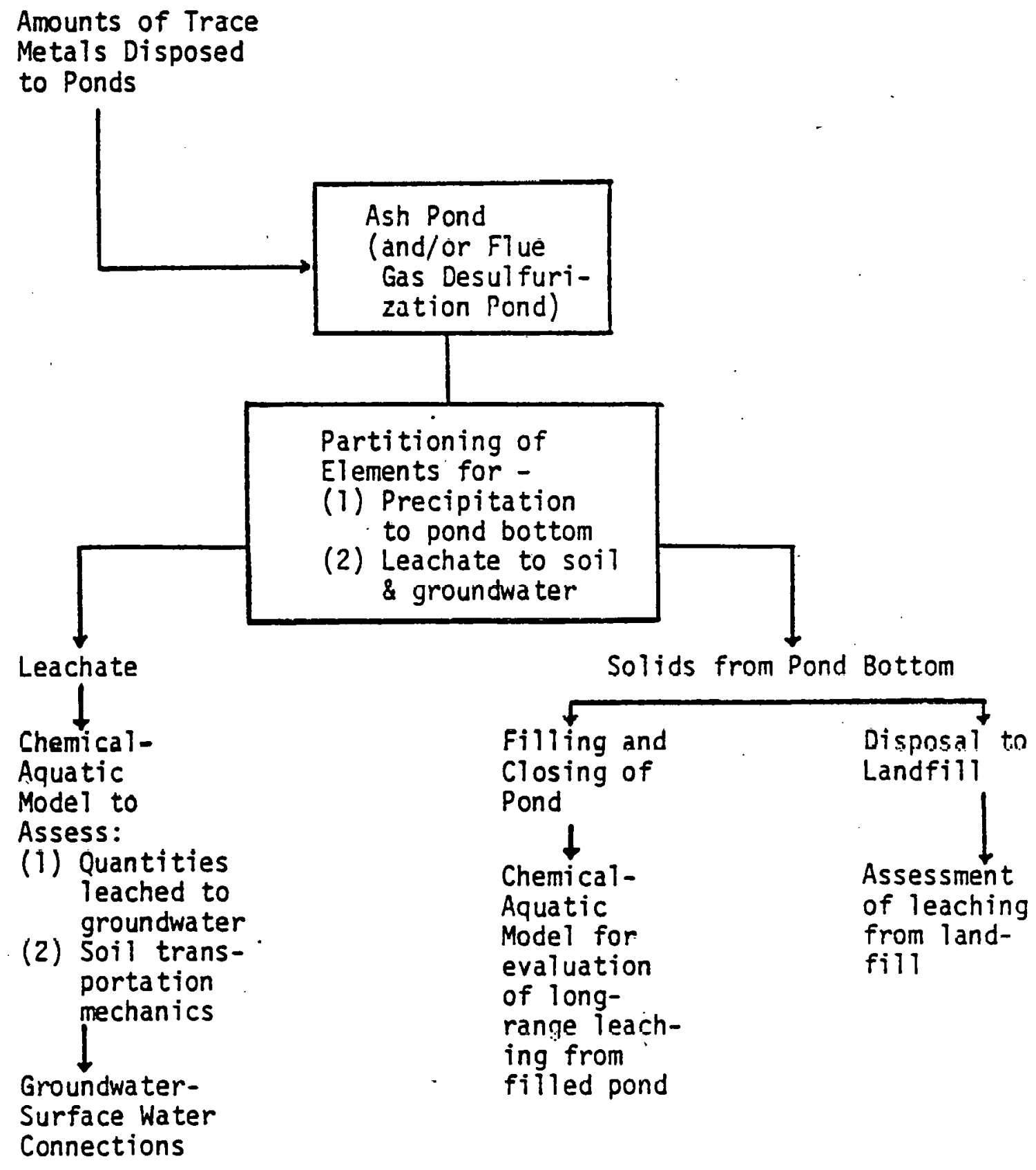


The basic components for a quantitative assessment of trace element impact are:

1. It is necessary to know the quantities of trace elements disposed to ash ponds and gas desulfurization ponds. These quantities can be determined somewhat accurately from existing engineering literature. Data concerning quantities of trace elements disposed in solid-liquid wastes can be obtained as regional averages and, in some cases, on a sub-regional basis. Although these data might not be applicable to a specific site, they could be used for an overall assessment of trace element contamination in regions with increasing development of coalfired power plants, such as the Four Corners region.

2. A key link in assessing the impact of trace element emissions is the development of an adequate chemical-aquatic model. Theis and associates have used a chemical-aquatic model for predicting trace element buildup in the soil - groundwater complex and we have in mind the development of a model that could perform the following tasks:

--One part of the model would partition the quantities of trace elements disposed to ponds into, first, amounts that precipitate and remain in the pond bottom and, second, amounts that are leached to the soil - groundwater complex.

--A second part of the model would predict the amounts of trace elements reaching the water table and, for trace elements not reaching the water table, the model would make statements about their distribution and transportation in the soil. Clearly, a model of this sort would be extremely helpful in assessing 
impacts of trace element emissions. To the best of our knowledge, a model which would perform these tasks does not presently exist. But the model used by Theis performed some of these operations, and it could be the building block for future work.

3. Another key link in assessing the impact of trace element emissions involves groundwater - surface water connections. Trace elements that are leached to area groundwater may eventually find paths to springs, rivers, and lakes depending on connections between the water table and surface waters. We did not find any studies that attempted to assess this pathway for trace elements, and the topic remains an item for future research. Engineering capability for charting paths of leached trace elements to surface waters is not substantial at this point in time.

4. Eventualiy ash ponds and ponds for desulfurization wastes wi]l fill and will have to be closed. In some plants, material from closed ponds will be transported to landfills and, in other plants, transport of solids to landfills will take place during the life of the pond. In all cases trace elements pose continued threats in terms of leaching to groundwater and in terms of soil contamination. Wastes transported to landfills will contain trace elements that may leach to the water table unless protective measures are taken; and from closed ponds in which wastes are not transported elsewhere, leaching of trace elements may also continue over extended. periods of time. As indicated in the preceding diagram, chemical-aquatic models would be helpful in assessing the buildup of trace elements in the soil - groundwater complex. But we have not found models in the literature that are capable of assessing such buildup from closed ash ponds and/or landfills. Additional research would be needed in this area before a somewhat complete benefit-cost analysis is possible. 
In the preceding paragraphs the importance of a chemical-aquatic model for assessing leaching from ponds and landfills has been indicated. However, another approach to quantification of trace element leaching might be a "fixed coefficient" approach. That is, attempts could be made to develop coefficients (assumed fixed) that relate to the proportions of trace elements leached from ponds and landfills to the ground. An additional set of coefficients would be developed that relate to the proportion of trace elements in soil that reach the water table. As an example of a beginning in this type of work, a table from a report by Wewerka and associates [10] may be helpful:

\section{Release Percentages of Elements During Static Leaching Experiments with Plant B Illinois Basin Coal Refuse}

Percent Leached of Original in Refuse Element

$\begin{array}{ll}>25 & \mathrm{Ca}, \mathrm{Co}, \mathrm{Ni}, \mathrm{Zn}, \mathrm{Cd} \\ 10-25 & \mathrm{Mg}, \mathrm{Mn}, \mathrm{Dy} \\ 1-10 & \mathrm{Na}, \mathrm{Al}, \mathrm{Vi}, \mathrm{Cr}, \mathrm{Fe}, \mathrm{Cu}, \mathrm{Pb} \\ <1 & \mathrm{~K}\end{array}$

Wewerka, et al. were studying the release of trace elements from refuse piles at coal preparation plants. They took samples of the refuse from three plants and conducted one day leaching experiments with it; results appear in the table above. It is clear that some elements appear more susceptible to leaching than others. Moreover, a series of laboratory experiments like this with coal ash might be useful in developing a set of coefficients of the type described above. 
If an attempt were made to develop a fixed coefficient approach it would be necessary to allow the coefficients to vary some as dependent on the following factors:

-- Pond pH will affect the solubility of elements; release rates will be higher in ponds with low $\mathrm{pH}$.

-- Soll porosity will affect the amount of trace elements reaching the water table, e.g., clay solls have moderately high attenuation capacities.

-- As discussed by Theis, iron and manganese complexes in soil may serve as sinks for collection of trace metals.

For these reasons, among others, any set of fixed coefficients for trace element release rates would need to be varied some for specific sites. Whether release rates and soil transportation paths of trace elements should be assessed by a chemical-aquatic model or by a set of fixed coefficients is a topic for future research. Although use of coefficients might be simpler, significant work has already been done on chemicalaquatic models and these might give good results with additional effort.

Methods for Reducing Environmental Impact Solid-Liquid Wastes

There are a variety of ways in which the possibility of contamination of soil, groundwater, and surface water by trace elements may be reduced:

--Ash from disposal ponds may be transported to landfills that are prepared and maintained by methods that reduce environmental impacts;

--Ash ponds may be lined with materials that wil? reduce or el iminate leaching of trace elements; 
--Ash may be used for other products. For example, there has already been use of recovered fiy ash in cement products and in the production of highway pavement. Also, there has been discussion of use of ash for recovery of metals, including iron, aluminum, and vanadium.

In this section, methods for reducing environmental impacts will be reviewed, and the adequacy of cost data on these techniques will be assessed.

(a) Landfills:

In some plants, bottom ash and/or fly ash may be transported directly to a landfill without prior disposal to ponds. However, if landfills are used, the more typical practice would be to take material that has collected in and beside ponds and transport it to landfills.

There are many kinds of landfills but, roughly, they may be classified into three categories:

(1) Dump: a dump refers to an area where waste is disposed directly to topsoil, and there is little or no consideration given to prevention of possible leaching, blowing, or soil contamination. In some cases, the siting of dumps may be based on considerations involved with prevention of drainage to surface waters and other environmental factors.

(2) Sanitary landfill: In what may be termed a sanitary landfill, there is more consideration about prevention of environmental damage. Material to be placed in the landfill is usually compacted and spread in thin layers; between the thin layers of 
compacted wastes cover material (frequently with clay base) is placed. Moreover, there is usually careful consideration of the location of the site.

(3) Chemically hazardous waste landfill: This category refers to landfills in which there has been a high degree of attention given to prevention of environmental damage. We may quote an EPA publication about these landfills [11]:

". . (Such landfills) provide complete long-term protection for the quality of surface and subsurface waters from hazardous wastes deposited therein. Such sites should be located or engineered to avoid direct hydraulic continuity with surface waters. Generated leachates should be constrained and subsurface flow into the disposal area eliminated. Monitoring wells should be established and a sampling and analysis program conducted. ... If there is potential for hazardous wastes to percolate or leach to groundwater, then the use of barriers and collection will be necessary. Due to potentially hazardous reactions, wastes must be segregated and records kept of disposal areas."

It is evident that what we have termed chemical waste landfilis provide a high degree of environmental protection. There are relatively few of those in the United States at the present time. Of course, one must take exception to EPA's statement that these landfilis provide "complete long-term protection." Over a period of 100 years, say, even the best liners may leak, clay sealing between layers may be chemically transformed, earthquakes may occur, and records may be lost. Thus, the idea that any landfill could provide complete long-term protection is probably mistaken. But chemical waste landfills do provide more protection than other landfill types.

(b) Lining of Ponds.

Another way that damage from trace elements in solid-liquid wastes 
may be prevented is the installation of lining beneath ponds. Lined ponds have some similarity to chemical waste landfills: there is usually careful consideration of pond siting; an attempt is made to significantly reduce (or completely eliminate) leaching to the water table and subsurface soil; and, in some cases, conditions in lower soil layers may be monitored by wells.

There are a variety of materials that may be used as liners and costs of lining depend on the material used. An EPA publication lists asphalt, polymeric membranes, and treated soils as three principal lining materials [12]. A few words about each of these materials, taken from the EPA publication, may be useful:

Asphalt: "(An asphalt liner in Pennsylvania) was a three inch thick tar. cement pavement. The aggregate for this liner was the same as is commonly used for street paving except tar was used as the binder rather than asphalt. A one-eighth of an inch thick coating of hot tar was then sprayed over the pavement as a sealer. The pavement was then protected by a two to three inch cover of crushed rock and an additional 12 to 18 inches of incinerator residue was placed over the pavement."

Polymeric Membranes: "Six polymeric liner materials have been proposed as sanitary landfill liners. They are polyethylene, polyvinyl chloride, butyl rubber, hypalon, ethylene propylene diene monomer, and chlorinated polyethylene. Polyvinyl chloride is the most popular of these materials." helpful:

The brief summary of polymeric liners by Dvorak may also be

"Flexible synthetic liners vary considerably in physical properties, chemical compatibilities, installation, durability, and cost. Plastic liners are particularly popular because they are impermeable and relatively inexpensive. Polyethylene (PE) was the first material to be widely used. It has since been replaced in popularity by polyvinyl chloride (PVC). Chlorinated polyethylene (CPE) is less affected by sunlight. It is inert and will not readily react with wastes, but it is also little affected by adhesives. Plies of the liner and CPE seams do not bind well. Chlorinated polyethylene has been used for the sides 
sides of some PVC-lined ponds to take advantage of the best qualities of both liners."

Treated Soils: A few lines from the previousily referenced EPA

publication may be useful:

"One commercial firm offers refined montmorillonite, a naturally occurring clay material, as an admixture to be used with native soils to provide a liner. . . Two types of volclay are available. In addition to the pure montmorillonite, there is a bentonite with polymer addition. The polymer addition is recormended when the fluid to be contained has a dissolved salt concentration exceeding $1000 \mathrm{ppm}$.

Another system that has been proposed is the use of a soilcement layer with a sealer coat of tar or asphalt. . ."

(c) Other Control Techniques

In addition to transport of waste from ponds to landfills and the use of liners beneath ponds and/or landfills, the main means of reducing the environmental impact of emitted ash is through use of the material for other products.

(1) Use of ash in highways and as cement replacement: It has been mentioned that recovered fly ash and bottom ash are being used as a complete or partial substitute for cement, especially in highway construction. The magazine Mining Engineering [13] made the following comments about this use:

"The ash industry is confident that highway engineers are about rady to accept power plant aggregates ds full-fledged construction materials. . I Industry optimism stems in part, from the successful placement of fly ash and bottom ash in environmentally sound applications, either as direct substitutes for or blended with conventional aggregates which are dwindling in supply or escalating in cost. . . Adding stature to the picture is the release of the Federal Highway Administration's Implementation Package 76-16 titled 'Fly Ash--A Highway Construction Material.' A companion study on the use of bottom ash in black base and bituminous surfacing is due for completion..." 
(2) Use of ash for metals recovery: the possibility of recovering a number of metals from fly ash and bottom ash is only in experimental phases but significant potential appears to exist for future development. Once again, some comments from Mining Engineering may be useful:

"Research is continuing on the development an: rafinement of economic processes to recover essential metals from fly ash. Laboratory sized experimental furnaces have been tested in Canada and at Iowa State University in Ames. The ever-rising cost of importing and refining the valuable ores are hastening the creation of new extraction methods. Available data indicate compounds of iron, aluminum, silica, chromium, vanadium, and/or magnesium can be successfully recovered."

\section{Costs of Reducing Impacts of Solid-Liquid Wastes}

In the previous section, three alternatives for reducing environmental impacts of disposed bottom ash, fly ash, and scrubber sludge were mentioned. Attention is now turned to a brief consideration of the costs of these alternatives.

(a) Landfills:

The cost of constructing and operating a landfill will vary enormously depending on the type of landfill. "Dumps" (i.e., open land disposal) will have low costs, and landfills designed for chemically hazardous waste will have quite high costs. The 1977 EPA publication cited previously places the capital and operating costs of a landfill. at $\$ 25 /$ dry ton $(1975 \$$ ); evidently, this is for what was termed a "sanitary landfill." The 1975 EPA publication previously cited places the cost of "land disposal" of solid wastes (evidently what we termed a dump) at about $\$ 4 /$ dry ton. The cost of "environmentally adequate disposal" (evidently what we have termed "landfill for chemically 
hazardous waste") is estimated to be about $\$ 50 /$ dry ton (1975 $\$$ ). The same publication indicates that a Union Carbide landfill providing a high level of protection had costs of $\$ 37 /$ ton of waste disposed. Based on these data, landfill costs might be estimated as follows:

Capital and Operating Cost Per Ton of Disposed Waste

(1975\$)

\begin{tabular}{l|c} 
Dump & $\$ 4$ \\
Sanitary Landfill & $\$ 25$ \\
$\begin{array}{l}\text { Landfill for Chemically Hazardous } \\
\text { Wastes }\end{array}$ & $\$ 50$ \\
\hline
\end{tabular}

These estimates are, of course, subject to considerable uncertainty. They refer to some "average" or "typical" landfill, and a landfill for a particular power plant might involve noticeably higher or lower costs. Moreover, the EPA estimates appear to be only best engineering approximations and are not based on collection of extensive empirical data. Thus, the preceding estimates should be viewed with some caution. Based upon these estimates and data in preceding pages on ash production rates at power stations in the Southwest, it is possible to estimate costs of placing power plant ash in landfills.

Total Annual Costs of Constructing and Operating Landfills for Power Plant Ash - Southwest Region - 1980 (1979\$)

\begin{tabular}{lr}
\hline Dump & $\$ 10.1$ million \\
Sanitary Landfill & $\$ 63.3$ million \\
Landfill for Chemically Hazardous Waste & $\$ 126.6$ million
\end{tabular}


The above costs assume that the total amount of bottom ash and fly ash to be disposed from Southwest power plants is 5200 tons/day; the costs are the annualized construction and operating costs.

Clearly, sending ash to a dump is fairly inexpensive. But such disposal would have little impact on reducing the probability of environmental degradation. On the other hand, costs of placing those wastes in sanitary landfilis or chemical waste landfills are quite large (approximating $\$ 60-\$ 100$ million per year in 1980 for the entire Southwest region). Of course, the latter, two types of 1 andfill would reduce the probability of environmental degradation in a very significant way.

(b) Liners

One of the ways to reduce potential contamination of groundwater is to install liners in ash ponds and/or scrubber sludge ponds. In a previous section, different kinds of liners (polyethylene, sprayed asphalt, etc.) were briefly discussed. EPA has presented estimates of the cost of different lining materials:

Material

Capital Outlay for Material and Installation (1979\$)

Polyethylene

Hypalon

Chlorinated Polyethylene

Soil - bentonite

Paved Asphalt with sealer.
$\$ 1.55 / \mathrm{sq}$. yd. $(\$ 6,500 /$ acre $)$

$4.00 / \mathrm{sq}$. yd. $(\$ 19,400 /$ acre $)$

$3.75 /$ sq. yd. $(\$ 18,100 /$ acre $)$

$.90 /$ sq. yd. $(\$ 4,400 /$ acre $)$

$1.95 /$ sq. yd. $(9,400 /$ acre $)$

Note: See EPA (1975). (Original EPA data were in $1975 \%$; these data were escalated to $1975 \$$ by using a price escalation factor of $\$ 33 \%$ for 1975-79). 
In a preceding section, it was estimated that the land requirements for disposal of ash by Southwestern power plants operating in 1980 would approximate 2600 acres over a 30-40 year period. For this amount of land in ponds, installation of liners would involve the following capital outlays:

Capital Outlay for Total

Liner Material Southwestern Power Plants Over. 40 Year Life

Polyethylene

Hypalon

Chlorinated Polyethylene

Soil - bentonite

Paved Asphalt with seater
$\$ 19.5$ million

50.4 million

47.0 million

11.4 million

24.4 million

Keeping in mind that these costs are spread over a 40 -year period, it is apparent that costs of installing ash pond liners are much less than costs of placing wastes in sanitary landfills or chemical waste landfills. For example, capital outlay for installing hypalon liners (the most expensive material) would be about $\$ 50$ million over a 40 - year period or in the neighborhood of $\$ 1.5 \mathrm{million} /$ year. Disposal of ash to a sanitary landfill would cost, perhaps, \$50-60 million per year. The landfill would, of course, provide much more complete protection. In a landfill, ash would be compacted and placed in thin layers divided by layers of clay and relatively impermeable material; the landfill would have liners and a system for for collection of any leachate; groundwater would be monitored with wells; etc. From an economic viewpoint, the question involves whether 
the relatively high cost of sanitary landfills and chemical waste landfills will generate economic benefits of a similar magnitude. As yet, we have no quantitative answer to this question.

Before leaving issues involving the cost of liners, it is worth mentioning that lining costs for some materials are relatively low. A bentonite soil liner provides some protection for groundwater at relatively low cost, and the same is true of polyethylene liners.

(c) Materials Recovery

Other alternatives for waste ash include production of aggregate for use with cement and the recovery of metals. At present, we have not found data on the cost of metals recovery or production of aggregate for cement. Three kinds of data would be required:

(1) Cost of producing these by-products;

(2) Revenues that can be obtained from the products;

(3) Cost of disposal of production residues.

Future literature search and engineering research would probably enable researchers to make some estimates of these magnitudes.

(d) Conclusions

The main objective of this section on costs was to determine whether adequate data are available for making cost analyses of reducing groundwater contamination. For the main alternatives--landfilling and pond lining--adequate cost data definitely exist. Data for production of by-products from ash were more difficult to find, but some approximate engineering estimates could probabily be made. 
Some Calculations on Trace Element Effects

In the preceding pages major emphasis has been on developing a framework for analyzing the environmental paths of trace elements in disposed ash. It would also be desirable to estimate the impact of these trace elements on environmental receptors, such as wildlife and human beings, but there is presently not enough scientific knowledge for making these estimates. Howeyer, some tentative and rough calrulations of possible impacts may be made. To make these calculations a number of assumptions were used:

\section{Bad Case I Assumptions}

(1) Focus is on the Four Corners power plant near the San Juan River in northwestern New Mexico. This plant has a capacity of $2000 \mathrm{Mw}$ and, for simplicity, is assumed to operate at $100 \%$ load factor. It is assumed that all bottom ash and recovered fly ash from this plant is sent to an ash pond, then flushed to Chaco Wash (an intermittent creek) which, in turn, enters the San Juan River. In effect, it is assumed that all disposed ash enters the San Juan River.

(2) The flow of the San Juan River is taken to be $2-1 / 2$ million acre-feet per year.

(3) The amounts of mercury, arsenic, and selenium in disposed ash are assumed to be:

Amounts of Element Entering Ash Pond

(kg/1000 MWH generated)

$\mathrm{Hg}$

As

Se 
Because it is not accurate that all ash pond waste from the $2000 \mathrm{Mw}$ Four Corners plant enters the San Juan River, the preceding assumptions imply a "bad case" of trace element water contamination, i.e., a case which may not occur but is still in the range of the possible. Also, we made some "Bad Case II" calculations:

Bad Case II Assumptions

(1) All assumptions are the same as for Bad Case I except that it is assumed that a 20-year collection of ash flows into the river during one year. This might be the case if an ash pond were damed, and the walls broke with a consequent outflow of ash piles that had been built up over long periods. It is not an absolute "worst case" assumption (for example, a 10-year ash build-up might flow out in three days with a dam break). It is a case which would have more $i l l$ effects than Bad Case I. Using these assumptions, concentrations of the three trace elements in the San Juan River would be:

\begin{tabular}{lccc}
\hline & $\begin{array}{c}\text { Present } \\
\text { San Juan River } \\
\text { Concentration }\end{array}$ & $\begin{array}{c}\text { Increase in Concentration } \\
\text { of. Element in River } \\
\text { Bad Case I }\end{array}$ & $5 \mathrm{ppb}$ \\
\hline Bercury & $\mathrm{n.a}$ & $.25 \mathrm{ppb}$ & $30 \mathrm{ppb}$ \\
Arsenic & $2.6 \mathrm{ppb}$ & $1.5 \mathrm{ppb}$ & $90 \mathrm{ppb}$ \\
Selenium & $<i \mathrm{ppb}$ & $4.5 \mathrm{ppb}$ & \\
\hline
\end{tabular}

In order to discuss the significance of these increases in concentration, it is necessary to compare them with some relevant standards: 


\begin{tabular}{lccc}
\hline & $\begin{array}{c}\text { Drinking water } \\
\text { Standard }\end{array}$ & $\begin{array}{c}\text { Ambient Water } \\
\text { Quality Standard } \\
\text { in some states }\end{array}$ & $\begin{array}{c}\text { F.D.A. Fish } \\
\text { Concentration }\end{array}$ \\
\hline Mercury & $.002 \mathrm{ppm}$ & .0005 & $.3-.6 \mathrm{ppm}$ \\
Arsenic & $.05 \mathrm{ppm}$ & $1.0 \mathrm{ppm}$ & \\
Selenium & $.01 \mathrm{ppm}$ & $1.0 \mathrm{ppm}$ & \\
\hline
\end{tabular}

Source: Borchardt, Cleland, Redman, and 01ivier, Viruses and Trace Contaminants in Water and Wastewater (Ann Arbonr Science, Ann Arbor, Michigan, 1977), pp. 148, 168-169, and 198-199.

Conclusions about the increase in concentration of trace elements under the Bad Case assumptions are:

(1) In both Bad Case I and Bad Case II, mercury would be a problem. In Bad Case I, the increase in river mercury concentration of $.25 \mathrm{ppb}$ does not exceed the drinking water standard or a widely used state ambient water quality standard. But, as mentioned in Chapter 2, a biomagnification factor from ambient water to fish tissue of $3000: 1$ is reasonable. Thus, ambient water of $.25 \mathrm{ppb}$ mercury would imply .7 ppm of mercury in fish tissue. This exceeds the level of mercury that is acceptable in fish consumed by human beings as set by F.n.A. r.nnsequently, Casa I assumptions imply a mercury problem. In Case II, the mercury probleill becomes worse. Case II mercury concentrations in fish tissue would exceed F.D.A. standards; also, mercury levels in the river would violate standards for drinking water.

(2) For arsenic, there appears to be no problem under Bad Case Iassumptions. The level of arsenic in the San Juan River is 
presently $2.6 \mathrm{ppb}$ and this would increase by $1.5 \mathrm{ppb}$ under Case I assumptions. The resulting concentration of arsenic would still fall short of drinking water standards of 10-50 ppb. In Case II, however, arsenic might begin to be a problem because the increase in concentration of $30 \mathrm{ppb}$ would start reaching toward drinking water safety standards.

(3) With respect to selenium, there might be some problem under Bad Case I assumptions, and there definitely would be a problem under Bad Case II assumptions. In Case I, selenium concentration increases by $4.5 \mathrm{ppb}$ which added to present in-stream concentration of less than $1 \mathrm{ppb}$ implies that the drinking water standard for selenium of $10 \mathrm{ppb}$ is still met. However, the level of selenium in the river is beginning to approach a danger point. In Case II, it is clear that selenium content of the river is in excess of levels that would be safe for consumption by human beings.

It may be concluded that these rough and tentative "bad case" calculations indicate some possible problems with trace elements in disposed ash. In Bad Case I, mercury would cause damage, and some problems with selenium might begin. In Bad Case II, there would be problems with all of the three trace elements selected for computations.

\section{Conclusions}

The calculations above indicate that there is some likelihood of human and wildlife health problems resulting from trace elements in disposed ash. But a number of aspects of ash disposal must be kept in 
mind before concluding that these are major problems.

1. In most cases, not all ash will be flushed to rivers. Indeed, in most cases, water in power plant ash ponds will be either recycled, evapotranspired, or seeped to the ground. The preceding "bad cases" may never occur.

2. Perhaps more probable than the "bad case" events is contamination of groundwater by ash pond trace elements. Although no preliminary calsulations were made of the likely extent of such contamination, there are two considerations that might mitigate any impact. First, on the Colorado Plateau--the most likely location for coal power plants--the distance from surface to the water table is sometimes large, and soil attentuation might prevent any significant groundwater contamination. Second, some of the groundwaters in this area are highly mineralized in their natural state, and incremental mineralization via seepage from ash ponds might not be important in comparison.

The conclusion that we reach is that at the present time damages from trace elements in disposed ash are problematic. "Bad case" calculations indicate possible damages, but there are important considerations that offset this conclusion. We recommend that additional research be conducted on the topic of trace elements in disposed ash. 
Notes and References for Chapter 3

[1] Dvorak, A. J.; Lewis, B. G., et a1., Impacts of Coal-Fired Power Plants on Fish, Wildlife, and Their Habitats, a report prepared for the U. S. Fish and Wildlife Service, March 1978.

[2] For a discussion of this model, see Appendix A of Chapter 2.

[3] U. S. Environmental Protection Agency, Report to Congress on Waste Disposal Practices and Their Effects on Groundwater, January 1977.

[4] Bonem, Gilbert and Mead, Richard, Future of the Non-Ferrous Metals Industry in the American Southwest (Project report to the National Science Foundation under Grant No. AER-76-02378, January 1979).

[5] Radian Corporation, "Coal-Fired Power Plant Trace Element Study," (a report prepared for the U. S. Environmental Protection Agency, Region 8, Denver, Colorado), September 1975.

[6] Klein, D. H.; Andrea, A. W.; Carter, J. A.; Emery, J. F.; Feldman, C.; Fulkerson, W.; Lyon, W. S.; Ogle, J. C. ; Talmi, T.; Yan Hook, I.; and Bolton, N., "Pathways for Thirty-Seven Trace Elements through Coal-Fired Power Plants," Environmental Science and Technology, September 1975.

[7] Dressen, D. R.; Gladney, E. S.; Owens, J. W.; Perkins, B. L.; Wienke, C. L.; Wangen, L. E., "Comparison of Levels of Trace Elements Extracted from Fly Ash and Levels Found in Effluent Waters from a Coal-Fired Power Plant," Environmental Science and Technology, October, 1977.

[8] Holland, W. F.; Wilde, K. A.; Pass, J. L.; Lowell, P. S.; Pohler, R. F., Environmental Effects of Trace Elements in the Pond Disposal of Ash and Flue Gas Desulfurization Sludge (a report prepared for the Electric Power Research Institute), September 1975.

[9] Theis, Thomas and Richter, Richard, "Chemical Speciation of Heavy Metals in Power Plant Ash Pond Leachate," Environmental Science and Technology, February 1979. Also, see Theis, T. L., Westrick, J. D.; Han, C. L.; Marley, J. J., "Field Investigation of Trace Metals in Groundwater from Fly Ash Disposal," Journal of the Water Pollution Control Federation, November 1978.

[10] Wewerka, E. M.; Williams, J. M.; Wanek, P. L.; and 01 son, J.D., Environmental Contamination from Trace Elements in Coal Preparation Wastes (report prepared by Los Alamos Scientific Laboratory for U. S. Environmental Protection Agency), August 1976.

[11] U. S. Environmental Protection Agency, Landfill Disposal of Hazardous Wastes, September 1975. 
[12] U. S. Environmental Protection Agency, Liners for Land Di sposal Sites: An Assessment, March 1975.

[13] National Ash Association, "Fly and Bottom Ash," Mining Engineering, March 1977. 
Chapter 4

Effects of Trace Elements on

Plants, Humans and Animals

Introduction and Overview

Terrestrial environments surrounding coal-fired power plants are repositories for toxic trace elements that escape into the atmosphere. The addition of these toxic trace elements poses the threat of ecological unbalance. Indigenous soils once considered nutritionally balanced with trace elements may be affected and mineral composition may no longer be constant. Negative impacts on terrestrial systems, therefore, could conceivably result if the deposited trace elements exceed the endogenous trace element concentrations. Ovorak and associates [1] caution that the impacts could be greater if the availability of the endogenous trace elements are already close to or beyond the tolerance limits for any biota living in the area.

In another chapter there is a discussion of the way that trace elements from electrical power generating stations may enter ecological environments when disposing of bottom ash and fly ash wastes. Specifically, trace elements may leach to the soils and the groundwater complex in contact with or beneath the ash ponds. If groundwater is then pumped for irrigating local croplands, these additional sources add to the soil load of toxic trace elements. Also, the problem may not be localized to the vicinity of the power plant since contamination of groundwater aquifers could be transported to distant areas through underground water movements. In a previous chapter, there was also a discussion of 
the deposition of toxic trace elements on lands distant from the coalfired power plants due to meterological conditions such as wind currents. In considering terrestrial contamination from a coal-fired power plant, the described complexity of interactions suggests that negative impacts are not only a local problem but also regional and global problems.

Much emphasis is placed on terrestrial contamination by trace elements because these eiements may enter into the human food chain through the ingestion of plants and animals nutritionally dependent on the spoiled lands. The chemical and structural composition of crops and grasses grown on spoiled lands are presumably altered with the increased availability of nonessential and overly abundant essential trace elements. Munshower and DePuit [2], in one section of a comprehensive study on the environmental impact of a coal-fired power plant suggest that changes in the nutritional make-up of grasses directly alter the dietary balance of grazing livestock and herbivorous wildlife feeding on the spoiled grasslands. Grazing animals further ingest toxic trace elements when ingesting soil along with the herbage. Purves [3] indicates that soil is a major dietary constituent for grazing animals. Purves cites intakes of soil in the order of 0.5 tons per cow per year, and for sheep a rise in intake of 40 percent of total dry weight in winter months.

In addition to nutritional unbalance, trace element toxicity is a worrisome problem. Absorption of toxic trace elements by plant forms, wildlife, livestock and humans is complex. Interruption of normal processes for different biological systems from the intrusion of toxic 
elements will vary in a way that is species specific. However, it is well established in the scientific literature that various plant species are susceptible to extinction should toxic trace elements, metals in particular, reach intolerable levels. Furthermore, severe morbidity, both reversible anc irreversible, and mortality have been documented following exposure to certain trace elements. These generalized deleterious effects followed once toxic elements were introduced into lower and higher mammalian forms through ingestion, skin absorption and inhalation.

The potential hazards of some elements have been known for quite some time, but historically precautions against human exposure have been either ignored or ineffectively executed. This is particularly true in the cases of goods marketed with hazardous contents, and hazardous ores mined without occupational safeguards. A more recent example of this toxicity problem is the chemical dumps lying beneath populated areas.

At this point some of the diseases caused by these trace elements are briefly discussed. Particles of the metal beryllium or its compounds whereever deposited, especially on the skin or in the lungs, do extensive local damage to tissue. Specifically, two severe outcomes are skin ulcerations and reduction in respiratory capacity. Beryllium disease was given the name berylliosis in the 1930 s by the physician Stefan Fabroni following animal experiments and evidence from known clinical rases in contact with the element. According to Schubert [4] human tragedy among 
hundreds of American beryllium workers unnecessarily occurred in the 1940's because Fabroni findings a decade earlier of the deleterious effects of beryllium, following occupational exposure to the element, were ignored. Possibly, the element having the longest documented history of toxicity is lead. Lead poisoning, sometimes referred to as plumbism or saturism, was first described by the Greek poet-physician Nicander more than 2000 years ago. In humans, either acute or chronic lead poisoning can result in functional injury. The severe health effects following chronic exposure to lead are permanent brain damage marked by mental deficiency and permanent kidney insufficiency. Also clinical and experimental evidence indicate that the metal mercury is capable of causing pathological degeneration in humans. Essentially, the same symptoms develop from either chronic or acute exposure. However, some induced symptoms, essentially from chronic poisoning, may be irreversible. Widespread human heal th hazards from mercury poisoning are reflected in the environmental contamination by mercury of Minamata Bay in southern Japan. As the dispersed mercury concentrations in the bay increased, translocation into the food chain occurred as the pollutant, concentrated in the fish that residents surrounding Minamata Bay were dependent on for their dietary needs. Through time chronic poisoning gradually occurred, and Minamata people showing minor symptoms or crippling disorders from ingesting the mercury contaminated fish became known as having Minamata disease. D'Itri and D'Itri [5] cite the identification of over 850 Minamata disease victims in Japan. It has been concluded by $D^{\prime} I$ tri and $D^{\prime} I t r i$ that the number is expected to be several times higher in the future as latent Minamata disease cases are identified, and more outbreaks are discovered. 
Goldwater [6], mentions that in 1956 and 1960 several outbreaks of mercury poisoning involving hundreds of persons took place in Iraq where farmers ate grain seed treated with mercurial fungicides. Similar outbreáks were later found in Pakistan and Guatemala. Cadmium is another metal for which human exposure can result in serious health disorders. It is clear from a health literature review by Leh and Lak [7] that chronic cadmium exposure could result in such chronic diseases as emphysema and the kidney dysfunction called proteinuria. Based upon evidence from cadmium poisoning in Kamioka, Japan, kidney and skeletal disorders can result from cadmium intoxication. From the severe pain that accompanied the skeletal disorder following the Kamioka outbreak, the cadmium induced disease became known as Itai-itai disease. It became clear later that contamination of the food, particularly rice, with cadmium was the main cause of the disease.

Trace Element Deposition from a Coal-fired Power Plant in the Southwest

Coal, especially in the Southwestern United States, is becoming a more important fuel source for producing electrical power so that, over time, it may be a significant source of toxic elements released into the environment. The time period in which the by-products of coal-fired electrical energy will have deleterious effects on various Iffe forms should be a central question rather than a speculative subject. Since potential consequences do exist it is necessary to begin accounting for the accumulation of these trace elements in the atmosphere. biosphere and hydrosphere. The Southwes't Energy Study Summary Report [8] 
described the need for a high degree of attention to be given to the accumulation of trace elements emitted from coal-fired electric power production:

"Insufficient information currently exists for quantifying health effects of particular levels of trace element emissions. There is a need to monitor the distribution and concentration of the elements known to have adverse effects on humans and other. biologic populations to restrict discharges in areas where chronic disorders in humans could develop."

Because available knowledge about the relationships between trace elements emitted from coal-fired power plants and the damage to exposed life forms is incomplete, additional information is needed on the maximum allowable concentration of these trace elements in life forms. Some literature concerning the absorption of certain trace elements by different life forms will be reviewed later. Before proceeding to this topic, however, some quantitative estimates on the accumulation of trace elements in the soils and vegetation surrounding a coal-fired power plant in the Southwestern United States will be given. Hopefully, these data will put some perspective on the problem.

A comprehensive study to investigate possihle rontamination of the native soil, vegetation and produce by the four corners Plant in San Juan, New Mexico was conducted by the Coal Reso:urce Work Group [9] in 1961-62 and repeated in 1971 as part of the Southwest Energy Study. Essentially, the study covers eight years of trace element accumulation since the Four Corners Power Plant came on-line in 1063. The ecological setting of the area surrounding the Four Corners Power Plant, as described in the report by the Coal Resource Work Group, is largely a semiarid area with sparse low shrub cover. Juniper and pinon 
trees along with ponderosa and douglas fir trees grow in San Juan County. The Animas and San Juan Rivers flow through the county, and the alluvium from these rivers is cultivated for garden vegetables, fruit, alfalfa and corn. The dry and economically unproductive land near the power station has been used primarily by the Navajo Indians for grazing sheep.

In the Coal Resources Work Group report, several trace elements in the terrestrial environment surrounding the Four Corners Power Plant were higher than those cited as average U. S. values. Table 1 shows the trace element content of the $0-6$ inch soil samples that were analyzed in 1971. The summary which follows is from the Coal Resources Work Group report. It was found that the soil contents of the elements arsenic (As), magnesium ( $\mathrm{Mg}$ ) and iron ( $\mathrm{Fe}$ ) tend to increase within closer proximity of the power plant; the metals sodium $(\mathrm{Na})$, Ytterbium (Ýb), barium ( $\mathrm{Ba})$, zirconium $(\mathrm{Zr})$, calcium $(\mathrm{Ca})$, chromium $(\mathrm{Cr})$, and vanadium $(V)$ show possible increases in soils nearer the power plant. The arsenic value at a distance of fourteen miles from the power station and direction ENE is qualified as an irregularly high 25 parts per million (ppm). The soil content of beryllium (Be), barium and strontium ( $\mathrm{Sr}$ ) are higher than the average U.S. soil content. Furthermore, the emitted trace elements calcium, beryllium, gallium (Ga) and sodium are higher than average within ten miles of the power plant, and titanium ( $T i$ ) and arsenic are higher than the U. S. average $10-25$ miles from the power plant. Analysis of a sample of wind-deposited fly ash that settles to the ground 1-2 miles west of the power plant indicated high levels of mercury and fluorine. The mercury and flourine concentrations of the wind-blown material were $.12 \mathrm{ppm}$ and $280 \mathrm{ppm}$ respectively. 
Table 1. Composition of San Juan Soils Collected in 1971 (depth 0-6 Inches)"

\begin{tabular}{|c|c|c|c|c|c|c|c|c|c|c|c|c|c|c|c|c|c|c|c|c|c|c|c|c|c|c|c|c|c|c|c|}
\hline \multirow{2}{*}{$\begin{array}{c}\text { Oistance } \\
\text { froin Power } \\
\text { Plant } \\
\text { (miles) }\end{array}$} & \multirow{2}{*}{ Direction } & \multicolumn{6}{|c|}{$\begin{array}{c}\text { Cheanical Analyses } \\
\text { (ppm) }\end{array}$} & \multicolumn{17}{|c|}{$\begin{array}{c}\text { Spectrographic Analyses } \\
(\mathrm{ppm})\end{array}$} & \multicolumn{7}{|c|}{$\begin{array}{l}\text { Spectrographic Analysis } \\
\text { (percent) }\end{array}$} \\
\hline & & pH & As & $\mathrm{Hg}$ & Cd & $2 n$ & $5 b$ & 8 & Ba & $B e$ & Co & Cr & $\mathrm{Cu}$ & Ga & La & In & HI & $\mathrm{Pb}$ & Sc & $\mathrm{Sr}$ & $v$ & $r$ & $Y_{b}$ & $\mathbf{Z r}$ & AI & $\mathrm{Ca}$ & $\mathbf{F e}$ & $k$ & Mg & $\mathrm{Na}$ & II \\
\hline 9 & ME & 8.2 & 4 & 0.02 & $<1$ & $51<$ & $<0.5$ & $<10$ & 2000 & 1.5 & 10 & 15 & 20 & 30 & 30 & 300 & 7 & 20 & 7 & 1000 & 70 & 30 & 3 & 200 & 10 & 3 & 2 & 2 & 0.5 & 3 & 0.2 \\
\hline 9.5 & $\boldsymbol{N}$ & 8.7 & 5 & .01 & $<1$ & 49 & $<.5$ & 20 & 1000 & 1 & 5 & 30 & 15 & 15 & M & 700 & 10 & 15 & 5 & 300 & 50 & 15 & 2 & 200 & 3 & 5 & 2 & 2 & .7 & 1.5 & .2 \\
\hline 10 & NH & 8 & 6 & .01 & $<1$ & 75 & 1 & 50 & 500 & 1 & 5 & 10 & 20 & 20 & $N$ & 200 & 15 & 20 & 7 & 200 & 70 & 20 & 3 & 150 & 7 & 5 & 2 & 2 & 1.5 & .7 & .15 \\
\hline 12.5 & $u$ & 8.1. & 1 & .03 & $<1$ & 55 & $<.5$ & 70 & 300 & H & 5 & 70 & 20 & 15 & 30 & 100 & 15 & 15 & 5 & 200 & 70 & 15 & 1.5 & 100 & 5 & 5 & 1.5 & 2 & 1.5 & .7 & .15 \\
\hline 13.5 & SH & 9 & 3 & .02 & $<1$ & 52 & $<.5$ & 20 & 1000 & 1.5 & 10 & 70 & 15 & $15^{\circ}$ & 50 & 300 & 50 & 20 & 7 & 300 & 50 & 20 & 2 & 150 & 5 & 2 & 2 & 3 & 1.5 & 1 & .2 \\
\hline 14 & EME & 8.7 & 25 & .02 & $<1$ & 55 & .5 & $n$ & 1000 & 1 & 20 & 20 & 20 & 20 & $\mathbf{H}$ & 700 & 15 & 20 & 10 & 1000 & 100 & 20 & 2 & 100 & 10 & 7 & 3 & 2 & .5 & 2 & .5 \\
\hline 14.5 & $\mathbf{E}$ & 8.9 & 4 & .01 & $<1$ & 47 & $<.5$ & $<10$ & 1000 & 1 & $?$ & 10 & 10 & 20 & $H$ & 300 & 5 & 20 & 5 & 300 & 70 & 15 & 2 & 200 & 5 & 1.5 & 2 & 3 & .5 & 1 & .2 \\
\hline 15 & E & 8.7 & 2 & $<.01$ & s & 33 & $<.5$ & $<10$ & 1000 & $n$ & 3 & 10 & 7 & 15 & N & 200 & 2.5 & 20 & $N$ & 150 & 20 & 15 & 2 & 200 & 5 & .3 & 1 & 3 & .3 & 1 & .15 \\
\hline 15 & $E$ & 8.6 & 3 & $<.01$ & < & 20 & $<.5$ & 50 & 1000 & 1 & 5 & 7 & 5 & 15 & 30 & 200 & 2.5 & 20 & $M$ & $\cdot 100$ & 20 & 10 & 2 & 100 & 5 & .15 & 1 & 3 & .2 & .7 & .10 \\
\hline 16.5 & MH & 8.1 & 6 & .03 & $<1$ & 50 & $<.5$ & 20 & 200 & $N$ & 5 & 50 & 20 & 15 & $\mathbf{H}$ & 150 & 15 & 15 & 2.5 & 500 & 50 & 10 & 1 & 70 & 1.5 & 7 & 1.5 & 2 & 1 & .7 & .1 \\
\hline 17 & SH & 8.7 & 4 & .02 & < & 45 & $<.5$ & 30 & 1000 & $N$ & $\mathbf{J}$ & 50 & 10 & 15 & H & 150 & 7 & 15 & 2.5 & 200 & 70 & 15 & 1.5 & 150 & 5 & 7 & 1.5 & 2 & 1. & .7 & .15 \\
\hline 19 & WNW & 8. 8 & 4 & .01 & $<1$ & 36 & $<.5$ & 20 & 1000 & $n$ & 3 & 20 & 7 & 15 & $\mathbf{N}$ & 150 & 7 & 20 & 5 & 200 & 30 & 15 & 2 & 200 & 3 & 5 & 1 & 2 & .7 & .7 & .15 \\
\hline 19.5 & SE & 9.2 & 3 & .02 & 4 & 40 & $<.5$ & 30 & 1000 & 1.5 & 5 & 20 & 15 & 15 & 30 & 300 & 7 & 15 & 5 & 200 & 50 & 20 & 3 & 200 & 7 & 1.5 & 1.5 & 2 & .5 & .7 & .2 \\
\hline 22 & E & 8.6 & 3 & $<.01$ & < & 33 & $<.5$ & 20 & 1000 & 1 & 5 & 10 & 10 & 15 & 50 & 200 & 2.5 & 20 & 5 & 200 & 30 & 15 & 1 & 200 & 1.5 & .7 & 1.5 & 2 & .3 & .7 & .2 \\
\hline 24 & SSE & 8.6 & 4 & .03 & $<$ & 37 & $<.5$ & 20 & 1500 & 1.5 & 7 & 20 & 20 & 15 & 30 & 200 & 5 & 15 & 5 & 300 & 50 & 30 & 3 & 100 & 7 & 1.5 & 2 & 2 & .5 & 1 & .15 \\
\hline 25 & SH & 8.3 & 6 & .02 & | & 62 & $<.5$ & 50 & 500 & 1 & 7 & 50 & 15 & 20 & 30 & 150 & 15 & 20 & 7 & 200 & 70 & 15 & 2 & 150 & 7 & 2 & 2 & 3 & .7 & 1.5 & .2 \\
\hline 25 & SSH & 8.7 & 2 & $<.01$ & $<$ & 19 & $<.5$ & 20 & 500 & $H$ & <] & 7 & 7 & 10 & $M$ & 100 & 2.5 & 15 & $n$ & 50 & 15 & 10 & 1 & 70 & 1.5 & .3 & 1 & 2 & .2 & .5 & .1 \\
\hline 25.5 & SH & 8.5 & 6 & .02 & $<1$ & 56 & $<.5$ & 50 & 500 & 1.5 & 5 & 30 & 20 & 20 & -- & 200 & 15 & 20 & 5 & 200 & 70 & 30 & 3 & 100 & 7 & 2 & 2 & 3 & 1 & 2 & .15 \\
\hline 25.5 & MNH & & 5 & .02 & 4 & 41 & $<.5$ & 20 & 200 & 2 & 5 & 30 & 15 & 15 & $\mathbf{M}$ & 150 & 7 & 15 & 5 & 100 & 30 & 20 & 2 & 200 & 3 & 3 & 1 & 2 & 1 & .7 & .15 \\
\hline 26 & $S H$ & 8.5 & 4 & .01 & 4 & 33 & $<.5$ & 30 & 500 & 1 & 5 & 15 & 10 & 10 & 50 & 150 & 7 & 20 & 2.5 & 150 & 20 & 10 & 2 & 200 & 2 & 1 & 1 & 2 & .5 & .7 & .15 \\
\hline 26.5 & $\mathbf{E}$ & 8.1 & 3 & .02 & \&) & 29 & $<.5$ & 20 & 1500 & 1.5 & 5 & 20 & 10 & 15 & 30 & 500 & 2.5 & 20 & 5 & 200 & 30 & 20 & 2 & 100 & 7 & 1.5 & 1.5 & $2^{\circ}$ & .5 & 1 & .15 \\
\hline 27 & E & 8.2 & 1 & .01 & 4 & 31 & $<.5$ & $N$ & 500 & 1 & 5 & 10 & 7 & 15 & 50 & 200 & 2.5 & 15 & H & 5000 & 20 & 15 & 2 & 200 & 5 & 3 & 1.5 & 3 & .5 & 1 & .15 \\
\hline 29 & $\overline{5}$ SH & & 4 & .02 & $<1$ & 41 & .5 & 40 & 700 & 2 & 3 & 30 & 15 & 15 & 30 & 200 & 5 & 15 & 5 & 70 & 30 & 15 & 2 & 150 & 3 & .5 & 1.5 & 1.5 & .3 & .3 & .15 \\
\hline 29.5 & SSU & & 8 & .04 & $<1$ & 33 & $<.5$ & 40 & 500 & 2 & 1 & 15 & 15 & 15 & $\mathbf{H}$ & 300 & 2.5 & 15 & 2.5 & 100 & 20 & 20 & 2 & 150 & 5 & 5 & 1.5 & 3 & .2 & .7 & .15 \\
\hline 31 & ENE & 7.9 & 2 & $<.01$ & 4 & 23 & $<.5$ & 40 & 1000 & 1 & 3 & 7 & 10 & 10 & $N$ & 200 & 2.5 & 20 & $H$ & 200 & 15 & 10 & 1.5 & 70 & 5 & .5 & 1 & 3 & .2 & 1 & .10 \\
\hline 32.5 & SSH & & 5 & $.1 t$ & 4 & 90 & $<5$ & 40 & 1500 & 2 & I & 30 & 30 & 30 & 50 & 300 & 10 & 20 & 7 & 200 & 70 & 30 & 2 & 150 & 7 & 1 & 3 & 3 & .7 & 1 & .2 \\
\hline 34 & E & & 3 & .03 & 4 & 70 & $<5$ & 30 & 200 & 2 & 5 & 30 & 20 & 15 & 30 & 150 & 7 & 30 & 7 & 150 & 40 & 20 & 2 & 200 & 5 & .7 & 1.5 & 3 & .5 & .7 & .2 \\
\hline Mean (Th & is report) & 8.5 & 4. & $8-.02$ & $<$ & 46 & $<.5$ & 25 & 850 & 1.2 & 6 & 35 & 15 & 15 & 25 & 250 & $<10$ & 20 & 5 & 450 & 50 & 20 & 2 & 150 & 5 & 3 & 1.5 & 2 & .5 & 1 & .15 \\
\hline U.S.Ayer & & -- & 5 & .11 & 1 & $0-100$ & 45 & 34 & 554 & 1 & 10 & 53 & 25 & 19 & 41 & 560 & 20 & 20 & 10 & 240 & 76 & $29^{\circ}$ & 4 & 240 & & 2.4 & 2.5 & 2.3 & .92 & 1.2 & .3 \\
\hline
\end{tabular}

One-half 1 inlt of detection subștltuted for all less than or not detected values. ( $N$ )

Spec. analyses for Ag, As. Au, Bi, Cd, Mo, Ho, Pd, Pt, Sb, Sn, Te, U, W. In, Si, P, Ce, Ge, Hf, Ir;, LI, Re, Ta, Th, MI, Pr, Md, Sw; and Eu onitted; none detected.

1/Shacklette, H.T., et al., 1971a. P.D. 1. 2/Swalne, D.J., 1955. 3/Shacklette, H.T., et al.

Source: Coal Resource Hork Group. 1972 Southwest Energy Study, Part $[11$. Trace Elenent Content of Solls and Vegetatlon in the Vicinity of the Four

Corners Power Plant, Draft Stataient. Appendix J-III. Table l. pp Jl-32. 
Vegetative samples were collected in 1971 in the same time period of the growing season as the 1961-62 samples and for which 1961-62 material had been saved. In the Coal Resources Work Group report, the trace element content of vegetation in San Juan Counity was stated as being low in 1961-62, but from 1961 and 1971 the effluent from the power plant raised the trace element content of some plant species above normal levels in the near vicinity of the power plant. Data arranged according to distance from the power plant are shown in Table 2. By comparing differences in amounts of trace element in 1961-62 and 1971, in the same plant species and at various distances from the power plant, evidence of contamination by certain metals is apparent. Between the two study periods, arsenic, barium, vanadium, cadmium, copper $(\mathrm{Cu})$, lead $(\mathrm{Pb})$, strontium, magnesium, iron and titanium showed significant increases within sixteen miles of the power plant.

Several issues are apparent from the assessment of trace element accumulation in the terrestrial environment surrounding the four Corners Power Plant. Unambiguousiy, trace element concentrations in local vegetation have increased between the two study perfods. It remains an open question whether deleterious effects will be evident for different plant species. Soil samples between the two study periods were not comparable because of different soil preparations. Based on the findings certain plant species are increasingly absorbing potentially toxic trace elements. 
Table 2. Composition of Vegetation Collected at Various Distances from Four Corners Power Plant

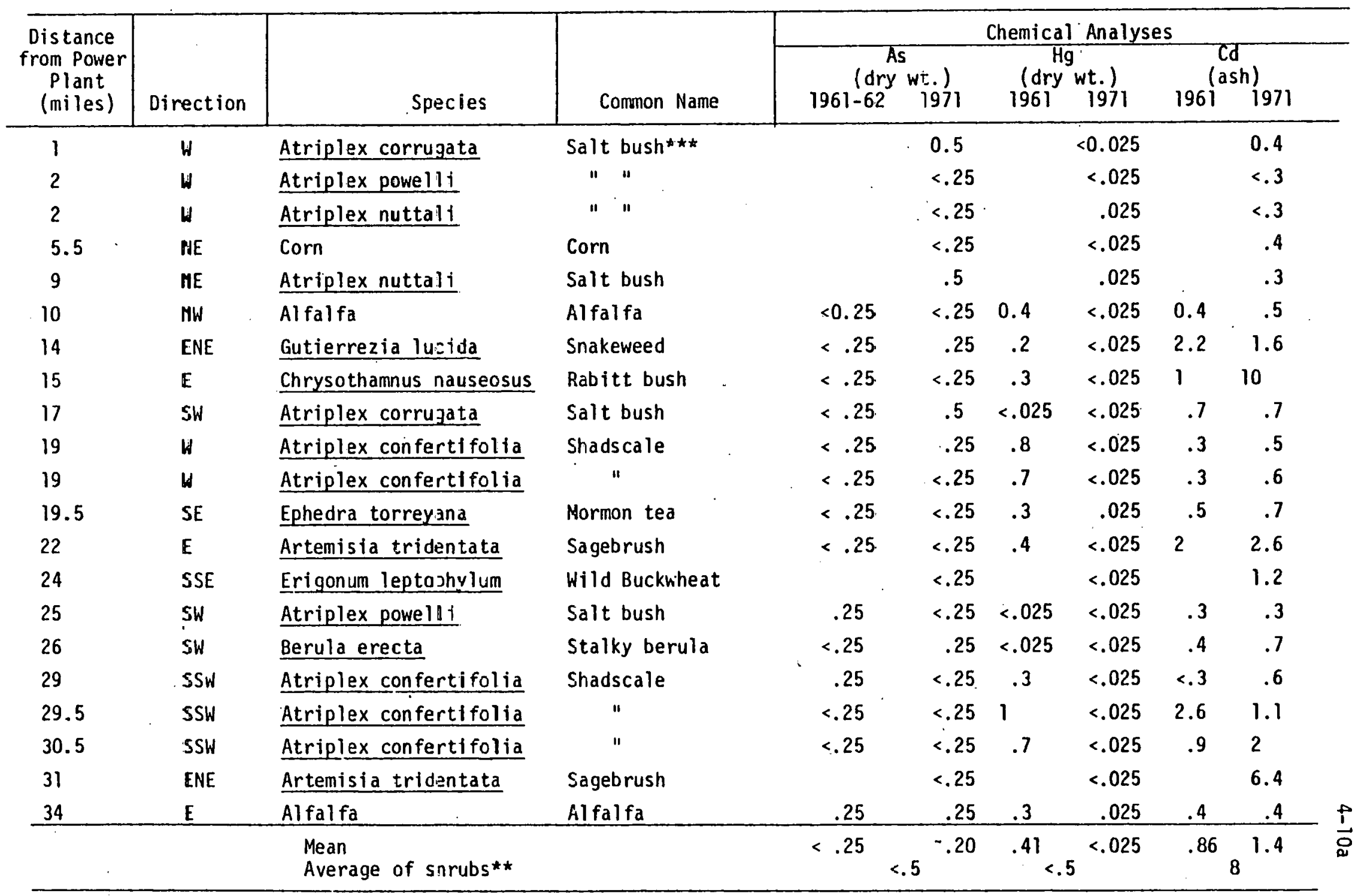

$N=$ Not detected.

$=$ Less than limit of sensitivity. $G=$ Greater than $10 \%$, or greater than value shown.

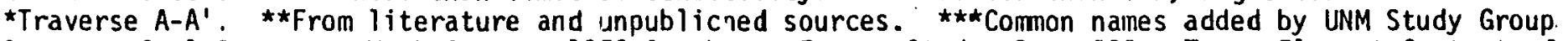

Source: Coal Resources Work Group. 1972 Southwest Energy Study, Part III. Trace Element Content of Soils and Vegetation in the Vicinity cif the Four Corners Power Plant, Oraft Statement. Appendix J-III, Table 6, pp 35-37. 
Table 2. continued

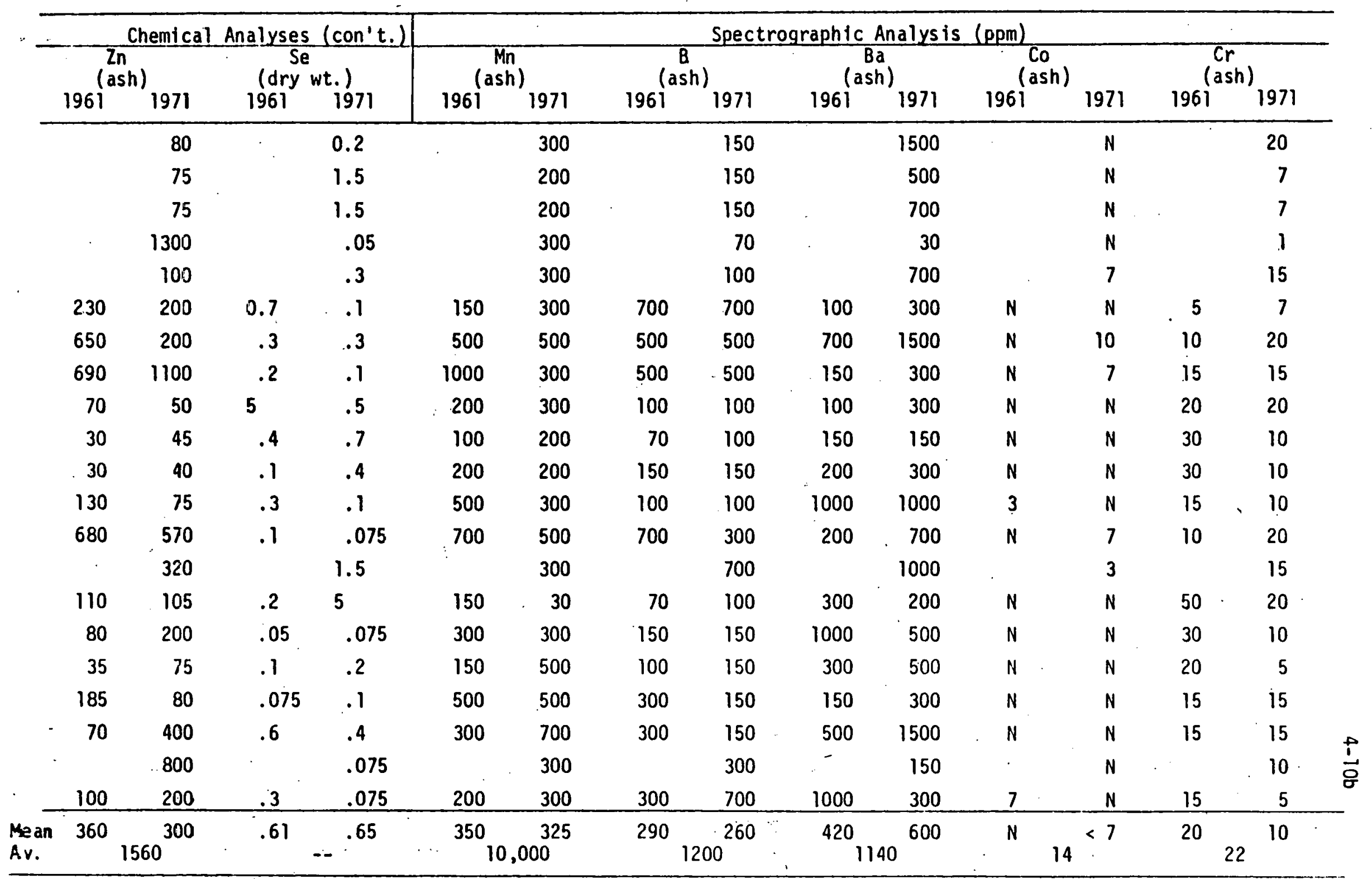


Table 2. continued

\begin{tabular}{|c|c|c|c|c|c|c|c|c|c|c|c|c|c|c|}
\hline \multicolumn{15}{|c|}{ Spectrographic Analysis (ppin) con't. } \\
\hline \multirow{2}{*}{\multicolumn{2}{|c|}{ 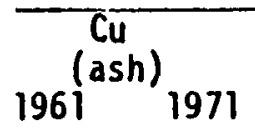 }} & \multicolumn{2}{|c|}{$\begin{array}{l}\text { Mo } \\
(a s h)\end{array}$} & \multicolumn{2}{|c|}{$\begin{array}{c}\text { Ni } \\
\text { (ash) }\end{array}$} & \multicolumn{2}{|c|}{$\begin{array}{l}\mathrm{Pb} \\
(\mathrm{ash})\end{array}$} & \multicolumn{2}{|c|}{$\begin{array}{c}S r \\
(\text { ash })\end{array}$} & \multicolumn{2}{|c|}{$\begin{array}{c}V \\
(a s h)\end{array}$} & \multicolumn{2}{|c|}{$\begin{array}{l}\mathrm{Zr} \\
(\mathrm{ash})\end{array}$} & \\
\hline & & $196 i$ & 1971 & $196 i^{-}$ & 1971 & $196 i$ & 1971 & $196 i$ & 1971 & $196 i$ & 1971 & $196 i$ & 1971 & \\
\hline & 30 & & N & & $<10$ & & 20 & & 300 & & 30 & & 100 & \\
\hline & 30 & & 3 & & $N$ & & $\mathbf{N}$ & & 500 & & 15 & & 30 & \\
\hline . & 30 & & $v$ & & $<10$ & & N & & 500 & & 30 & & 70 & \\
\hline & 200 & & 2J & & $<10$ & & $N$ & & 200 & & $N$ & & $N$ & \\
\hline & 50 & & N & & $<10$ & & 20 & & 1000 & & 50 & ' & 150 & \\
\hline 70 & 100 & 70 & 15J & 10 & $<10$ & 30 & 20 & 3000 & 2000 & $N$ & 15 & $N$ & 70 & \\
\hline 150 & 150 & 15 & in & $<10$ & $<10$ & 50 & 150 & 2000 & 2000 & 20 & 70 & 70 & 200 & \\
\hline 200 & 500 & 20 & $1 j$ & $<10$ & 10 & 30 & 100 & 5000 & 5000 & 15 & 20 & 20 & 70 & \\
\hline 20 & 20 & H & H & $<10$ & $<10$ & 30 & 50 & 500 & 1500 & 30 & 20 & 70 & 100 & \\
\hline 20 & 20 & H & $H$ & $<10$ & $<10$ & $N$ & $N$ & 1500 & 1500 & $N$ & $<15$ & 50 & 50 & \\
\hline 10 & 30 & H & H & $\mathbf{N}$ & $N$ & $N$ & 20 & 1000 & 1500 & 15 & $N$ & 70 & 30 & \\
\hline 30 & 30 & $<7$ & H & $<10$ & 410 & 20 & 30 & 7000 & 5000 & 30 & 20 & 100 & 100 & \\
\hline \multirow[t]{2}{*}{300} & 300 & 20 & 15 & 10 & 15 & 30 & 70 & 5000 & 3000 & 20 & 50 & $\cdot 70$ & 70 & \\
\hline & 70 & & 15 & & 10 & & 50 & & 5000 & & 50 & & 70 & \\
\hline 30 & 30 & 3 & H & $N$ & 10 & $\mathbf{N}$ & 20 & 500 & 500 & 30 & 30 & 200 & 150 & \\
\hline 20 & 50 & $n$ & $n$ & 10 & 10 & $N$ & $N$ & 5000 & 3000 & 20 & $<15$ & 70 & 150 & \\
\hline 10 & 30 & H & 10 & $<10$ & $N$ & $\mathbf{N}$ & $N$. & 300 & 700 & $<15$ & 15 & 150 & $N$ & \\
\hline 20 & 30 & M & n & 15 & $<10$ & $\mathrm{~N}$ & 20 & 500 & 2000 & $<15$ & $<15$ & 20 & 70 & \\
\hline \multirow[t]{2}{*}{200} & 15 & 10 & $n$ & $<10$ & $<10$ & 30 & $N$ & 3000 & 1500 & 20 & 15 & 70 & 100 & $f$ \\
\hline & 300 & & $?$ & & $<10$ & & 30 & & 3000 & & 15 & & 30 & c \\
\hline 150 & 100 & $N$ & 10 & $<10$ & $N$ & $\mathrm{~N}$ & 30 & 1500 & 7000 & 30 & $\leq 15$ & 150 & 20 & \\
\hline \multirow{2}{*}{\multicolumn{2}{|c|}{${ }_{22}^{90}{ }^{100}$}} & $<\vec{I}$ & $<7$ & 10 & 10 & $\infty 20$ & $\infty 35$ & 1900 & 2200 & $\infty 18$ & $\infty 25$ & 80 & 80 & \\
\hline & & \multicolumn{2}{|c|}{12} & \multicolumn{2}{|c|}{12} & \multicolumn{2}{|c|}{80} & \multicolumn{2}{|c|}{1935} & & & \multicolumn{2}{|c|}{25} & \\
\hline
\end{tabular}


Table 2. continued

\begin{tabular}{|c|c|c|c|c|c|c|c|c|c|c|}
\hline \multicolumn{2}{|c|}{$\begin{array}{c}\mathrm{Fe} \\
\text { (ash) }\end{array}$} & $\begin{array}{r}\text { Spe } \\
\text { (a } \\
196)^{2}\end{array}$ & $\begin{array}{l}\text { rograp } \\
197\end{array}$ & \multicolumn{2}{|c|}{$\begin{array}{c}k \\
\text { (ash) }\end{array}$} & t) & 1971 & $\begin{array}{l}T i \\
\text { (ash) }\end{array}$ & ${ }_{1971}$ & \\
\hline : & 1.5 & & 3 & & 7 & & $N$ & & 0.15 & \\
\hline & .5 & & 1.5 & & 10 & & $N$ & & .07 & \\
\hline & .7 & & 1.5 & & 7 & & N & & .07 & \\
\hline & .15 & & 5 & & G & & 10 & & .002 & \\
\hline & 1.5 & & 2 & & 7 & & $N$ & & .15 & \\
\hline 0.2 & .2 & 1.5 & 3 & G & G & 1 & 1 & 0.015 & .03 & \\
\hline .1 & 2 & 3 & 2 & G & 7 & 2 & 1 & .15 & .3 & \\
\hline .5 & 1 & 3 & 2 & G & G & 1 & 1 & .03 & . 15 & \\
\hline .5 & .5 & 3 & 2 & 7 & 7 & N & $N$ & .07 & .05 & \\
\hline .3 & .3 & 3 & 3 & 10 & 10 & $N$ & $N$ & .015 & .03 & \\
\hline .5 & .3 & 5 & 3 & 7 & G & $N$ & $N$ & .03 & .03 & \\
\hline 1 & .7 & 2 & 1.5 & 7 & 7 & .7 & $<.2$ & . & .1 & \\
\hline \multirow[t]{2}{*}{.7} & .7 & 3 & 3 & G & G & 3 & 2 & .1 & .15 & \\
\hline & 1 & & 7 & & $G$ & & 1 & & .15 & \\
\hline 1 & 1 & 1.5 & 1.5 & G & 10 & N & N & .1 & .1 & \\
\hline .5 & .7 & 1 & 1.5 & G & 10 & $N$ & 1 & .07 & .7 & \\
\hline .5 & .3 & 1.5 & 2 & 7 & 10 & N & N & .02 & .05 & \\
\hline .5 & .5 & 1.5 & 2 & 5 & 5 & N & N & .03 & .50 & \\
\hline \multirow[t]{2}{*}{1} & .7 & 1.5 & 2 & G & 5 & 1 & $N$ & .1 & .07 & $t$ \\
\hline & .5 & & 7 & & G & & 2 & & .05 & 욤 \\
\hline .7 & .5 & 1 & 1.5 & 10 & $G$ & .7 & 1 & .1 & .02 & \\
\hline .6 & $1.1^{.7}$ & 2.2 & 2.7 & -- & -- & -- & - & .07 & $.11^{.12}$ & \\
\hline
\end{tabular}


Impact of Trace Element Emissions on Vegetation

Addressed at this time are the impacts of trace element emissions on vegetation. Many factors affect the availability of trace elements to vegetation. Generally, the pathways and behavior of trace elements in terrestrial systems are site specific. Variations in temperature, precipitation, and soil properties will modify the availability of trace elements to particular plants. Another important factor is soil $\mathrm{pH}$. Kubota and associates in their discussion [10] on the consequences of nutrient soil imbalances concluded that an acidic soil may enhance the availability of iron or manganese but limit that of selenium or molybdenum. In alkaline soils, the reverse is true. They further indicate that phosphorus is less available in alkaline, arid soils than moist soils: Also, organic matter may promote the uptake of iron but retard the uptake of copper.

Availability also is dependent on the chemical composition of the trace element. Nicholas [II] concludes that the chemical composition of transition metals will affect the mechanism of action of these elements and their coordination compounds: Soluble forms, such as simple ions, complex inorganic ions or ion pairs and chelated or soluble-organic complexes, will determine in part the translocation of trace elements within the terrestrial system. As an example, the ionic state of a transition metal will control its uptake from the soit and transport through plant cellular membranes.

Plants possess the characteristic behavior invclving intake of suf-. ficient quantities of essential major elements and less essential trace elements when these nutrients are available in soils. Purves concluded that it 
is possible for the trace element composition of plants in an uncontaminated environment to be stabilized; the content of each element being within the limits which can be defined by the soil content. Through bioaccumulation of essential nutrients, the rate of absorption of the essential elements by vegetation is high compared to the amounts in the soil. As summarized in the report by the Coal Resource Work Group, these essential elements are the cations calcium, magnesium, potassium and iron, and the anions phosphorus and nitrogen. As a second group of elements that are essential but regarded as micronutrients, manganese, boron, barium, copper, zinc, strontium, cobalt, molybdenum and titanium may also be absorbed in amounts greater than in the soil.

It is important to realize that as soil concentrations of the above nutrients are increased, plants will continue to accumulate the elements and concentrations toxic to the plants may be reached. For example, Broadman [12] describes copper and manganese as essential elements of the electron transport chain in photosynthesis, the metabolic process by which visible light is trapped by plants and converted into chemical energy. A toxic supply of these elements may retard growth or destroy certain plant species. Through a series of pot experiments, Purves found copper to have an inhibiting effect on the growth of clover; Walsh and associates [13] in a two year field study showed significant reductions in yields of snapbeans following copper additions to the soil. Another important point is that plants can bioaccumulate excess amounts of either nonessential elements or 
those required in small amounts. This latter group consists of antimony, arsenic, cadmium, mercury, chromium, nickel, lead, vanadium, zirconium and beryllium. Furthermore, these elements taken up by plants are a worrisome problem beyond plant toxicity if subsequently passed into the food chain.

There are other factors which must be taken into account when assessing trace metal toxicity in the terrestrial environment. For one, toxicity is unique, since the toxicity of a trace element may vary widely for different plant species. Dvorak and associates summarize the situation by concluding certain plants can accumulate large quantities of an element without any apparent damages whereas other species are completely inhibited by much lower tissue concentrations. Initially, some trace elements may be of a harmless form when deposited. However, certain micro-organisms inhabiting the soil have the ability to effect chemical transformation whereby an element is changed from a benign state to a toxic chemical state. Another potential for antagonistic effects is the snyergistic interactions among the elements. Kubota and associates imply such chemical compounds as calcium-magnesium, phosphorus-copper, phosphorus-zinc, iron-several heavy metals, sulfurselenium and boron-calcium may have detrimental effects on the growth of certain plants species.

Two other points not mentioned in the previous paragraph that need emphasis are (1) the portion of the plant in which the trace element accumulates, and (2) the time period in which a toxicity problem occurs. It is clear that the extent to which any element is present as a contaminant in plants is species specific. However, the 
toxicity for any element is dependent upon the part of the plant in which it accumulates. That is, impairment of any metabolic. process, such as photosynthesis or respiration, is related to the site of concentration. Adding to the complexity of the problem, the root. accumulation of a given trace element may be tolerated by one plant species but not by another. The same holds true for the shoots and the leaves. This suggests the mechanisms by which potentially toxic trace elements from a coal-fired power plant inhibit plant metabolism must be determined for each plant species subjected to the effluents.

As indicated in the second point, a division in time exists such that the transport of toxic trace elements is an immediate problem: and/or a long-term problem. Elements such as boron, cadmium, nickel and zirconium are readily taken up by plants. Increased deposition of these elements and subsequent plant uptake would, therefore, result in short-term problems from soil accumulation. However, plants in general have the ability to restrict their uptake of cadmium and lead. Nevertheless, the effects of cadmium and lead soil contamination are transferred into a future period at which time a point. will be reached when contaminative levels are excessively elevated thus rendering the land unusabje.

Unquestionably it is important to ascertain if trace elements accumulate in the edible portions of plants. As previously emphasized, foremost attention should be given to the pathways in which potentially toxic trace elements enter the food chain.: Thus, trace element accumulation in high-yalue crops for hüman consumption are of utmost concern. For the same reason, concentrations in the edible parts of rangeland 
plants consumed by grazing livestock warrant concern. Furthermore, it needs to be emphasized that potential problems cannot be excluded if trace elements accumulate in the nonedible plant parts. For example, one or more elements may become elevated beyond tolerable limits in plant roots so tilat sensitive plant species are reduced, or completely eliminated. For grazing. livestock, which are naturally adapted to converting natural habitat cover or relatively inexpensively grown grasses into protein food, a substitution of more expensive feeds such as grain would be necessary. Also, herbivorous wildlife are affected if certain habitat cover are depleted. Based on natural adaptation, wildlife will forage new areas capable of providing adequate sustenance. But, those species incapable of adapting to a different area could conceivably be reduced in population or eventually eliminated. For wildlife moving to new areas, there may be competition with already existent wildlife. In any event, the translocation of trace elements to plant species. that results in plant destruction could result in the reduction of the number of herbiyorous wildlife species in the given area.

In Appendix $A$ to this chapter, effects of specific trace elements (e.g., arsenic, barium, beryllium) on plants are discussed.

Toxicity Versus Essentiality of Selected Trace Elements in Animals

All animal species require certain elements in trace amounts to maintain normal biochemical functions. In these life forms, the trace elements work with in compartments that are part of an ordered dynamic system. At any time, the biologic implication of an essential 
element within the ordered system can vary depending on the body burden of the specific element. Normal biochemical functions may be disrupted when the concentration of an essential element exceeds some beneficial level. Equilibria also may be disrupted when elements not required for the existence of man and other animals accumulate beyond tolerable levels.

Luckey and Venugopal [65] suggest that over twenty elements are essential nutrients or stimulatory agents and along wfth nonessential elements exhibit no toxicities when received by man and other animal sys tems in minute amounts. The essential elements promote normal tissue growth or the normal function of metabolic processes. Toxicity is the inherent capability of an essential or nonessential element to affect adversely these functions. According to Venugopal and Luckey [74], the adverse effect could be initiated through the disturbance of membrane permeability; the blocking of an essential enzyme leading to an alteration or interference of the regulatory mechanism of a physiologic process; a conformational change in the RNA or ONA structure resulting in impaired genetic information. Gross toxicosis in mammals may be expressed by various morphologic or functional alterations. Among these alterations are increased general morbidity; retardation in growth and/or intellectual capability; detrimental hereditary effects from genetic mutations; the appearance of chronic diseases and tumors leading to decreased longevity. Summaries of the biologic functions of some essential elements and their toxic effects are given in Table 4.

The difference between a beneficial level of an element (or tolerable level of a nonessential element), and a toxic level may be large or small depending on the element and its chemical form. Toxicity 
Table 4

Biologic Functions and Toxicities of Essential Trace Elements ${ }^{a}$

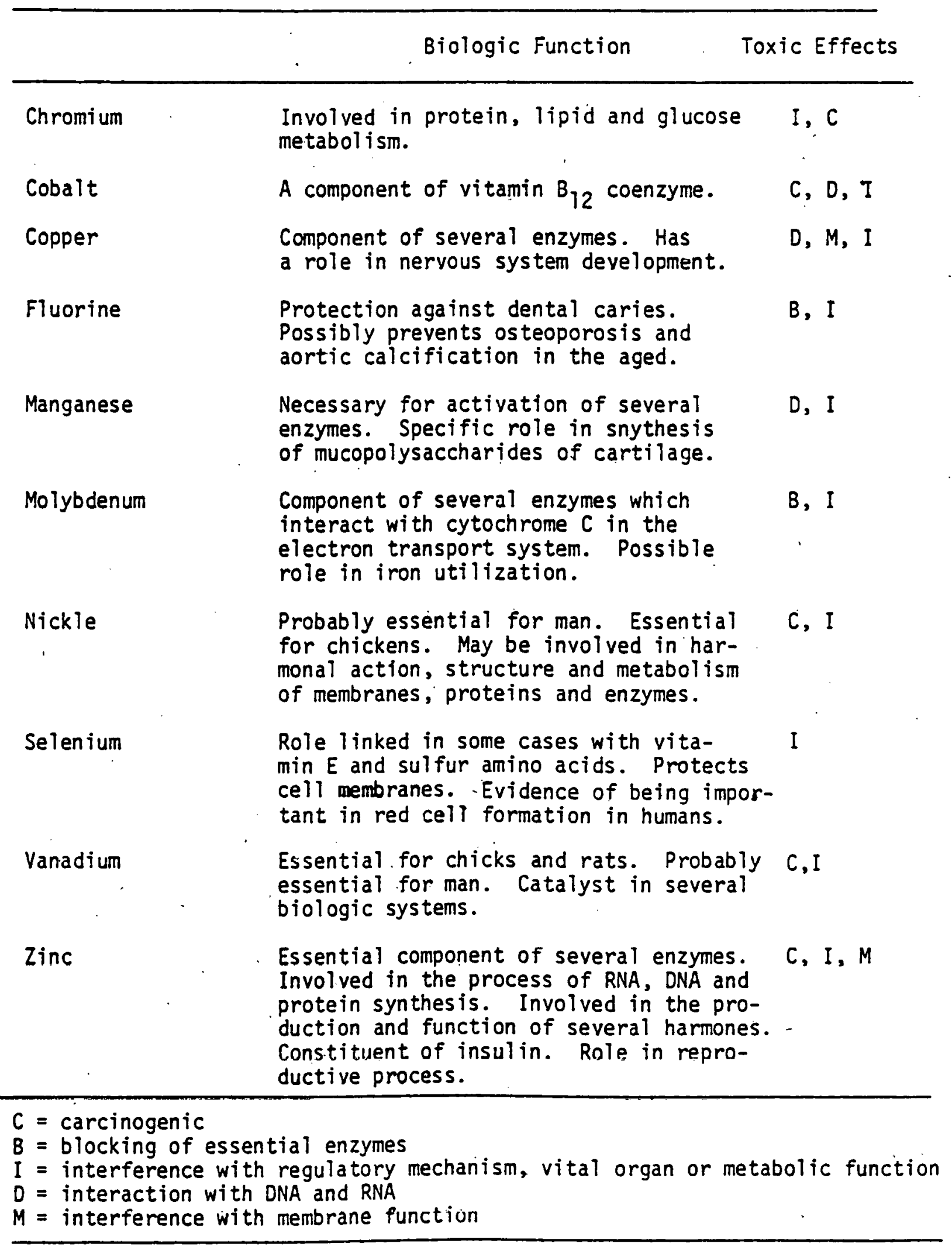

a Based on a table from Zingaro [67] with additional information from Dvorak [ 1$]$, Luckey [68] and Sawicki [69]. 
generally occurs when the accumulative tissue concentration of an essential or nonessential element causes damage to a critical organ or some biologic system. More than one organ or system may be affected depending on the affinity of an element for particular tissue compositions in addition to the amount of the body burden of the element in the characteristic organs or systems. The accumulation of an essential or nonessential element in tissue concentrations high enough to induce tonxir efferts may result from a dysfunction or breakdown of the homeostatic excretory mechanisms, or overburdening of these mechanisms from the voluntary or involuntary excessive intake of a trace element. When a homeostatic system is impaired, the tendency toward stability in normal body states may be inhibited greatly.

Synergisms or antagonisms among trace elements also potentiate biologic instability in man and other animals. Innoxious elements at low tissue concentrations may form chemical compounds which in themselves augment biologic damage in animals. Furthermore, some elements and their compounds that have a low order of toxicity may catalyze the chemical reactions of other pollutants to more undesirable pollutants. As one example, a report by Schroeder [66]. describes manganese as a necessary element in all animals with a low order of toxicity; but, the element's compound manganous sulfate is capable of catalyzing a chemical reaction in the ambient atmosphere forming the highly noxious substance sulfuric actd when sulfur dioxide is present. Leach [70] discerned from a liferature survey that an interaction between iron and manganese occurs in the human intestinal tract. Schroeder has indicated that large concentrations of the manganous ferrous ion are toxic for mammals and birds. 
It is clearly evident that aerobic and anerobic microorganixmx biologically transform inorganic mercury to highly toxic organic methyl mercury in aquatic environments. Also, various fish species that absorb methyl mercury biologically magnify the substance such that the accumulation in tissue may greatly increase beyond the amount taken up from the water. D'Itri [47] cites one case that demonstrated muscle tissue levels of mercury in pike 3000 times greater than the level of the water in which the fish were taken. The mercuric ion is one chemical state of mercury from which the biologic methylation reaction can proceed. Based on evidence that the cobalamin enzyme found in humans can readily transfer its methyl group to the mercuric ion, the Organization for Economic Cooperation and Development [71] have questioned if the methlyation of inorganic mercury could also take place in humans. Luckey and Venugopal assert that the biotransformation of the essential trace element chromium from a harmless form into a carcinogenic form is possible in humans. Apparently, chromium induces a form of cancer that orginates in the bronchi, the larger air passages within the lungs, following chronic inhalation of insoluble chromium oxide. Luckey and Venugopal also indicate that insoluble nickel and cobalt sulfides can be transformed to active carcinogenic forms in animal cells. Along with the chemical form of an element, the mode of entry influences the toxicity a trace element may have on different animal species. Inhalation and ingestion are the primary modes of entry in man and other animals. Trace elements that come in contact with the outer skin usually are not absorbed through the skin structures. 
However, skin inflamations have been known to erupt following the prolonged contact of some trace elements with the skin.

Following the ingestion of a trace element many factors are involved in its absorption from the intestinal tract. Briefly, absorption occurs by active transport and by simple or facilitated passive diffusion through the intestinal cellular membranes. The three segment: of the small intestine are the ma.jor sites where intestinal absorption takes place.

particles following inhalation. It is the small particles from which trace elements are most effectively extracted from the lungs into an animal's blood stream following inhalation. Natusch and associates [72] report that particles less than one micron in equivalent aerodynamic diameter deposit predominantly in alveolar regions where absorption efficiency is 50 to 80 percent. These respiratory regions consist of small saclike pockets throigh whose walls gaseous exchanges take place. The larger inhaled particles are said to be deposited in the nasal, pharyngeal and bronchial regions of the respiratory system. These larger particles subsequently are removed by a sweeping action to the stomach.

Modes of entry into fish of trace elements are by ingestion and active transport or diffusion through the gills. Similar to other life forms, the toxicity of a trace element varies among different fish species. The $\mathrm{pH}$ and temperature of a lake or river affect the chemical form of trace elements and, in turn, their availability for uptake by fish. Chronic exposure to a potential toxicant may result 
in the reduced viability of a fish species. Since fish are on the top of the food chain, contaminated fish are a direct source of trace elements in the human diet.

In Appendix $B$ of this chapter, there is discussion of the adverse implication of selected trace elements in animals. Some information on actual dose-response relationships also appears in Appendix $B$. 


\section{Appendix $A$ to Chapter 4}

In this Appendix, the behavior and effects of selected trace elements in vegetation is described. Emphasis is placed on those species classified as priority pollutants by the Environmental Protection Agency (EPA), and included in Keith and Telliard's toxic pollutant list.[14]. Information from the literature about the relationship between levels of trace elements availabis to plants and the actual plant uptake by species is shown in Table $A T$ at the end of this Appendix. To obtain evidence on plant contamination, many of the literature sources derived results from pot experiments under experimental conditions different from field conditions. Such experiments provide valuable information for drawing conclusions about the probable detrimental effects of trace element contamination in soil. In Table Al, the plants and trees resemble species grown in at least one of the Four Corner States $[15,16$ and 17].

Dvorak and associates have made an extensive review of the soil and plant literature related to trace element accumulation and toxicity. Much of the information in Table $\mathrm{Al}$ and the following descriptions on behavior and toxicity of trace elements is from this work.

Arsenic is believed not to be essential for plant.growth. In most aerated soils, the oxidative pentavalent state is common and most toxic. Organic arsentates are generally toxic to plants. Organisms, such as Pseudomonas brevicaule and methanobacterium are capable of converting inorganic and certain organic arsenic compounds to simple organic arsines. There appear to be marked variations in susceptibility to arsenic toxicity within plant groups. From a review of the plant literature, Dvorak and associates found legumes, cucumber, 
sweet corn and onions to be least tolerant among the high value production crops whereas asparagus, tomato and carrot appeared to be the most tolerant. For a review of the literature on arsenic activity in soils and plants one is referred to Liebig [18] and the previously cited studies by Dvorak, et al. [1] and Purves [3].

Barium is neither beneficial nor toxic for plant growth. However, soils may not support plant life if the exchangeable barium exceeds the exchangeable calcium and magnesium. Certain plants are barium accumulators; therefore, these plants can take up barium from soils in which the concentration of this element is low. For a more detailed review of the literature on the barium-plant relationship see Vanselow. [19], Dyorak et al. and Kubota et al. [10].

Beryllium has been shown to inhibit plant growth to a greater extent when it is present in soil in the soluble form than when fixed in soils. Dyoark and associates found from the plant and soil literature that soil $\mathrm{pH}$ enters as an important factor in the beryllium fixation process since beryllium has a strong tendency to form complexes and colloidal aggregates when soil $\mathrm{pH}$ is above 5.5. Experiments indicate toxicity to plants is reduced greatly when soil $\mathrm{pH}$ is above this level.

Griffitts and associates [20] concluded from a literature review that the roots of plants grown hydroponically contain more beryllium than the higher parts, but similar effects have not been established for plants in soil. Most studies on vegetation grown in soils show that leaves contain more beryllium than either twigs or fruit. In contrast, some desert shrubs in the Southwest possibly contain more beryllium in their twigs than in their leaves. Field work by Curtin 
and associates [21] found that lodgepole pine and Englemann spruce in Colorado and Idaho contain indetermined amounts of beryllium in the ash of twigs. Liquids condensed from volatile exudates transpired by these trees also contained detectable levels of beryllium.

Boron is among the elements essential for plant growth. However, in some plants, such as cereal crops, excess boron produces damaging effects. Dvorak and associates concluded from several published sources that interactions of boron, calcium and nitrogen occur in soils and plants. The effects of these interactions were described as being dependent on piant species, soil type, element concentrations and environmental conditions. In general there is a narrow range between boron deficiency and toxicity. Purves observed marked yield reductions for oats and radishes in treated soils where the water soluble boron content in the soil exceeded $10 \mathrm{ppm}$. From information on boron-plant tolerance compiled by Bradford [22], production crops sensitive to excess boron in order of increasing tolerance are blackberry, lemon, cherry, peach, fig, strawberry, grape, kidney, bean and Jerusalem artichoke. Boron semitolerant production crops in order of increasing tolerance are barley, pea, lima bean, sweet potatoe, onion, carrot, pepper, corn, potatoe, cabbage, milo, radish, oats, celery, mustard, parsley, alfalfa, lettuce and tomatoe. Bradford has complated an extensive literature review on the boron-plant relationships.

Cadmium produces toxicosis in plants. Page and associates [23] studied cadmium uptake by a number of plant species grown in solution culture and different cadmium concentrations. It was evident from their work that the tolerance of different species varied by the 
cadmium levels in solution in the range 0.1 to $10 \mathrm{ppm}$. At solution concentrations of $0.2 \mathrm{ppm}$ a 50 percent reduction in growth was evident for beans, beets and turnips. Further demonstrated by this work was the ease with which cadmium in solution can enter plants. The availability of cadmium in soils varies by soil type and soil $\mathrm{pH}$, whereby the element is more ayailable in acid sandy soils than in neutral or alkaline soils with large amounts of clay or organic matter. The ability to accumulate cadmium varies by plant species. Generally, the plant parts above ground accumulate more cadmium than the roots. Cadmium toxicity in plants includes wilting, chlorosis, necrosis and reduction in yield. Purves cautions, however, not all plants that readily take up cadmium give the appearance of phototoxic symptoms, and that a normal crop may be produced which is unsafe for animal or human consumption. Furthermore, cadmium can replace zinc in plant tissue and thereby affect the balance of essential elements in the plant. The cited literature suggests that the deleterious effect from cadmium concentrations in vegetation extend beyond plant destruction whereby humans, livestock and wildlife may be adversely affected. Dvorak et al. has available an extensive literature review on both cadmium accumulation and toxicogenic effects in plants.

Small soncentrations of chromium in soil may stimulate plant growth, whereas large concentrations may be harmful. Toxic quantities of chromium have been found in soils developed on serpintine rock, and areas have been known to be unproductive because of the high levels of available chromium in those soils. The effects of chromium vary with species and the chemical state of the element. It appears little 
is known about the cycling of chromium in the environment, whereby information on the chemical transformations of chromium in water and soils have come mainly from controlled experiments. Several researchers have established chromium usually exists in soil as insoluble oxides which are more available at $\mathrm{pH}$ values less than or equal to 4.0.

Few plants seem to accumulate chromium. There is evidence suggesting leafy vegetables that tend to accumulate iron may be the most effective accumulators of chromium in edible plant parts. Several examples of chromium toxicity in plants have been cited in a National Academy of Science (NAS) publication on the element [24]. The addition of chromium at $150 \mathrm{ppm}$ in soil was toxic to orange seedings. At $5 \mathrm{ppm}$ in culture solution chromic sulfate inhibited the growth of corn seedlings, and chromium as chromate at $16 \mathrm{ppm}$ reduced the growth of tomatoes, oats, kale and potatoes. The NAS publication, Dyorak et al. and Pratt [25] have more complete discussions on the effects of chromium on vegetation.

Cobalt, a micronutrient in plants, indirectly affects plant growth. From several sources Nicholas [11] describes the element requirement in nodulated root plants as usually being associated with the production of cobamide coenzyme compounds by the bacterium rhizobium. These enzymes are known to be involved in several enzymatic reactions in plants and animals. Certain plant species are the principal source of cobalt in the ruminant animal. Essentially, either high or low concentrations of cobalt in soil may result in an imbalance of the nutrients produced by plants. Nicholas further mentions that little is known about the effect of cobalt on non-nodulated root plants. 
Norrish [26] summarized the literature on the association of cobalt with other soil constituents. Cobalt is associated with manganese in soils, and, if it is in manganese oxides it will have the same $\mathrm{pH}$ as manganese. There is indication that the uptake of cobalt fertilizer by plants may be dependent on the manganese content of the soils. Clay minerals and iron oxides also fix cobalt; however, in normal soils it is the manganese oxides that hold the cobalt. Apparently, the availability of cobalt is increased in water logged soils.

There appears to be a wide range between which the levels of concentration of cobalt in plants may be considered to have beneficial or toxic effects on most plant species.

One is referred to the report by Vanselow [27] on cobalt for data on the status of the element in plant tissues.

Copper is another essential micronutrient for plants. As taken from a National Academy Science (NAS) publication on copper [28], the copper content of the soil may not be an indication of the excesses of the element in rooted plants. From a previously cited report by Kubota and associates, copper forms complexes in soil with organic matter. Apparently, organic matter may retard the uptake of copper by plant roots. The uptake of copper by plants is further limited by soils having $\mathrm{pH}$ values of 6 and above. The element is believed to be much more available to plants grown in poorly drained soils because of the inicrobial activities associated with these condftions. Again from Kubota and associates, antagonistic interactions among the elements phosphorous and copper 
may have effects on the growth of certain plant species.

Copper toxicosis in plants is rarely observed under normal conditions. However, Purves states toxic effects have been known to occur on mine spoils or on agricultural soils following the application of copper enriched fertilizers. The absolute concentrations of copper that result in pathologic damage depend upon the plant species. In general, legumes are particularly susceptible to copper toxicity. The build-up of copper on agricultural soils is considered a long term problem as levels high enough to produce copper toxicity in plants are gradually reached. Specific data on the phytotoxic effects of copper can be found in the literature review by Reuther and Labanauskas [29].

Fluoride is the chemical state in which fluorine occurs as compounds. Dvorak and associates concluded from the literature that over 90 percent of soil fluoride may be unavailable for plant uptake. Fleischer et al. [30] and Purves indicate that most plants, with the exception of a few fluoride accumulators, have limited capacity to take up fluoride from soils. Either gaseous or particulate airborne fluorides are a greater potential threat to plants than soil deposited fluorides. Between the two forms of airborne fluorides, gaseous fluorides may cause greater damages since they can be more readily absorbed through the outer leaf or needle tissues.

Following the absorption of fluorides by the needles of conifers, Gordon and associates [31] found the compounds usually translocate 
through the needles and mostly build-up injurious concentrations in the needle tips. Studies have indicated that gaseous fluorides, in most plant foliage, are not readily translocated from the leaf tips or margins to other plant parts. Foliar damage is usually characterized by necrotic foliar lesions, decrease in chlorophyll and decreased growth rate when accumulations are excessive.

The effect of fluoride on plants typically varies by the chemical compound in which the fluoride occurs and by plant species. Fluoride toxicity in plants is further influenced by concentration, duration and frequency of exposure, temperature and light intensity. Among the plants susceptible to fluoride toxicity, the most susceptible appear to be the high valued productive crops corn, sorghum, grape, citrus and some other fruit trees such as apricot and plum. Some conifers are highly sensitive to fluorides. For a more complete literature review of fluoride phytoxicity see Drorak et al., Brewer [32], Fleischer et al. and McCune et al. [33].

Lead is not essential for plant growth. Lead in surface soils has been reported as being significantiy higher then the amounts in deep soils. Bases for the higher concentrations of lead in surface solls are a result of natural mechanisms, whereby plants take lead from the soil and the lead returns to the soil when the plants decay. It seems lead poorly translocates within plants so that only very small fractions reach the edible plant portion. The minimal uptake of lead in suil by plants mainly stems from the lead being tightly fixed in the soil. However, appreciable amounts of lead may translocate 
to leaves when various plant species are grown in soils with relatively high lead levels.

Lead can penetrate the protective plant cuticles following surface contamination of plants, however, the surface deposited lead can be washed off by rain. In contrast, lead taken up through the root system can not be removed with washing. Lead concentrations in any plant material can increase markedly with the age of growth. Mitchell and Reith [34] found a 30 to 40 fold increase in the lead concentration of grass from the summer to the winter. From a study by Rains [35], a sharp increase was found in the concentration of load in wild out3 from the spring to the winter. The translocation of lead from plant roots to the aerial portions of plants is further affected by the rate in which the plant grows. Potential phytotoxic effects from lead contamination in soil appear to be a long-term problem as lead accumulates in upper soils.

Lead has been one of the more extensively studied elements for potential phytotoxic effects. One is referred to Sandstead et a1. [36], Harr [37] and Grandjean [38] for the chemistry of lead in soi] matter. A discussion and references on the lead content in forage and vegetable crops can be found in Brewer's [39] summarization of the literature on effects of lead in plants. Additional studies and references on lead with emphasis on the soil-plant interrelations can be found in Arvik and Zimdahl [40], Rolfe [41] and Purves.

Manganese is an essential element for the electron transport function in plants. Toxic concentrations of manganese most often 
occur in plants grown on acidic soils, in that, the soil levels of available manganese increase as the $\mathrm{pH}$ decreases. In the presence of an excess supply of manganese, the root uptake of the element may continue with subsequent transfer to the derial plant parts:

Evidence of excess manganese varies by plant species. A common phytotoxic symptom is the brown spotting of leaves. Excess take up of the nutrient manganese may induce deficiencies of other mineral nutrients in plants such as iron deficiency. In high manganese soils, sugar beet and oat are most tolerant, whereas potatoe and barley are less tolerant crops. The crops most sensitive to high manganese concentrations are the brassicaceous varieties cauliflower, marrowstem kale and rutabaga. For a more detailed discussion on manganese chemistry in soil and soil-plant relationships see Boardman [12], Matrone [42], Black [43] and Labanauskas [44].

Mercury seems not to have any biological functions. Extremely small amounts of mercury can be tolerated by life forms. In low pH soils, mercury is adsorbed on the organic matter, but as the $\mathrm{pH}$ values increase large amounts of the mercury are adsorbed by the soil minerals. Evidence has been made available by Rogers [45] indicating that the methylation of mercury occurs in terrestrial environments. From the same source it is further evident that methyl mercury does not accumulate in soils. Apparently, mercury can volatilize in soils and thereby escape into the atmosphere as volatile elemental mercury or as volatile dimethyl mercury. Every known form of mercury compound is potentially toxic. Elemental mercury vapors have been assumed as the primary source 
of phytotoxicity.

Because it is well established that mercury adversely affects higher manmalian species, a knowledge of the translocation of mercury through plants is important for discerning the pathways in which mercury may enter the food chain. Various investigators have reported that solutes of mercury can move through plant parts. From an experiment involving radioactive tagged mercury fly ash, it was found that mercury can be leached from fly ash, absorbed by plant roots and translocated to the leaves. Solutes of mercury can also be absorbed through the plant's surface membranes and translocated to other parts of the plant. More in-depth reviews of mercury chemistry, soil-plant relationships and biologic impacts have been prepared by Goldwater [6], Schroeder [46], D'Itri [47], Nobbs [48], Dvorak [1] and Rogers.

Molybdenum is an essential element for higher plants. There is a direct relationship between high soil $\mathrm{pH}$ values and molybdenum levels in plants. At $\mathrm{pH}$ values above 6.0 , molybdenum is fairly moblle in soil and more available for plant uptake. In summary, soils that support high molybdenum concentrations in plants tend to be poorly drained, neutral or alkaline and high in organic matter.

Molybdenum is an essential element of fiye enzymes that catalyze unrelated reactions in plants. Most plants appear to tolerate excess tissue concentrations of molybdenum and toxicity is rarely observed in the field. Molybdenum uptake and accumulation is generally high in legumes which possess the threat of molybdenum toxicity to animals 
feeding on such plants. One is referred to Loneragan [49], Dvorak et al., Johnson's [50] report on molybdenum, Allaway et al. [51], Davis et al. [52], and Nicholas [11] for further discussions, in addition to references, on the molybdenum soil-plant relationships and plant tissue content.

Nickel has not been demonstrated to be essential for the development and growth of plants. Nickel is naturally present in most soits in amounts that vary from $5-500 \mathrm{ppm}$, al though soils formed from serpintine rock may greatly exceed this range for nickel content. The soluble and exchangeable nickel contents of soils, rather than the total nickel content, are better measures of the availability of nickel to plants. Nielsen [53] concluded from the literature that many complex factors affect the content of extractable nickel in different soils. Among those cited by Nielsen are the soil parent material, soil physical factors (e.g., aeration, temperature, water content and degree of development), soil chemical factors (e.g., pH, organic matter content, and oxidation-reduction potential) and biological factors (e.g., microbial activity, plant-root excretions and depletion of mineral elements by plant roots and microorganisms). Nickel is said to interfere with the uptake of iron by plants. The nickel concentrations that produce phytotoxicity are usually above $50 \mathrm{ppm}$, al though $28 \mathrm{ppm}$ in oat straw and $44 \mathrm{ppm}$ in alfalfa were associated with decreased crop yields. Vanselow's [54] report on nickel, the National Academy of Science's document on nickel [55], Nielsen et al. and Dvorak have summaries of the extensive literature on the tissue concentrations 
and toxicity of nickel in plants.

Selenium has not been established as necessarily essential for cultivated crops and range grasses. The availability of selenium to plants is basically controlled by the soil pH and the chemical form of the element in the soil. Organic selenium compounds and inorganic selenates are the forms of selenium most available to plants. These forms generally occur in high concentrations in alkaline soils of semiarid and arid areas. In arid and semiarid areas, selenium in the soluble forms can easily be leached from the upper soil layers and redeposited within the deeper soil strata. Under such conditions, more selenium is made available to deep rooted plants than shallow rooted plants; however, selenium deposited in the second or third foot soil layers can contribute significantly to the selenium content of shallow rooted plants, such as the grasses. Some compounds of selenium can be volatilized from biological processes within plants. From these processes, selenium is released into the atmosphere in amounts related to the amounts of volatile compounds within the plant. Alfalfa is one such plant that releases volatile selenium.

Since the selenium compounds found in plants have analogous properities to those of sulfur compounds found in nature, similar metabolic pathways may exist for the two elements. It has been suggested that selenium may replace sulfur in some amino acids. However, the evidence in the literature is not conclusive to rully support a selenium-sulfur exchange physiologic action in plants. 
The variation in the selenium content of different plant species seems to exceed that of any other element. In general, the selenium. content of plants decreases with advancing development during the growing season. The following information on selenium phytotoxicity is from a literature review by Ganje [56] and a document on selenium by a NAS panel [57]. Selenium injury is indicated by stunting of the plant. Soluble selenium compounds are injurious to seed germination and growth in some of the nonaccumulator selenium species. Excess selenium characteristically produces a snow-white border chlorosis of the leaves of some cereal plants. Although, progressive lessening of chlorosis is apparent in successive leaves as wheat plants fully develop. For barley, rye, sorgo, and wheat excess selenate produces the visual symptom of snow-white chlorosis of the leaves.

Like molybdenum, selenium is known to accumulate in some range plants in sufficient quantities to render them toxic to grazing animals. Most seleniferious plants include species that are less palatable to grazing animals than other range land grasses, which are lower in selenium; however, animals will eat the former under conditions of grazing. Indepth literature reviews, other than the studies by Ganje and the NAS panel on selenium, are available from Dvorak et al. and 01dfield et al. [58].

Vanadium has not been conclusively demonstrated as an essential element for crop plants. The availability of vanadium to plants is determined by its extractable content in soils. However, the total and extractable vanadium levels may vary greatly among different soil 
types. In general, impeded soil drainage along with an anaerobic soil environment can result in large increases in extractable vanadium from soils. Hopkins and associates [59] concluded from an unpublished source that plants grown in river alluvium, on which most of the produce is grown in the Southwest, contain more vanadium than plants from residual soils of the Southeast.

Great variation in uptake occurs among different plant species. From a study in which 16 fruits and vegetables were analyzed, parsley and radishes were determined to contain considerabiy more vanadium than the other vegetables. Solution culture studies involving soybean and pea plants showed a marked accumulation of vanadium in or on the roots as compared with the aerial plant parts. Except for a few vanadium accumulator plants, the amount of vanadium taken up by plants from the soil is largely retained in the roots and only very little is translocated to the aerial plant parts. Pratt [60], in a review on vanadium toxicity in plants, found no reports indicating either deficiency or toxicity of vanadium under field conditions. One is referred to Hopkins et al., Dvorak et al. and Pratt for literature reviews on vanadium and plant life.

Zinc is an essential element for plant life. The availability of zinc to plants generally increases as the soil pH decreases. Zinc accumulation in soil apparently is favored where there has been a continued build up of organic matter in the upper soil layers.

In plants, zinc is believed to be distributed throughout the 
roots and aerial parts. Following the application to leaves of a radioactively tagged form of zinc, the element was detected in the edible plant parts. Zinc can be accumulated by plants to toxic levels. Under excess zinc conditions, leaves often show signs of iron chlorosis. When analyzing four vegetables for zinc toxicity, Purves [3] found inhibition of growth to occur when the concentration of zinc in the soil exceeded $60 \mathrm{ppm}$. Zinc that accumulates in plants is not considered a problem for mammalian species, since the plant constituents that bind the element are insoluble in the ruminant animal and human intestinat environments. Additional information on the zinc status in soils and plants can be found in Chapman's literature review on zinc [61], Drorak et al. [1], Purves [3] and Sandstead et al. [36]. 
Table Al

Concentrations of Selected Trace Elements Which Have Been Found to Have Toxic Effects in Some Terrestrial Plants*

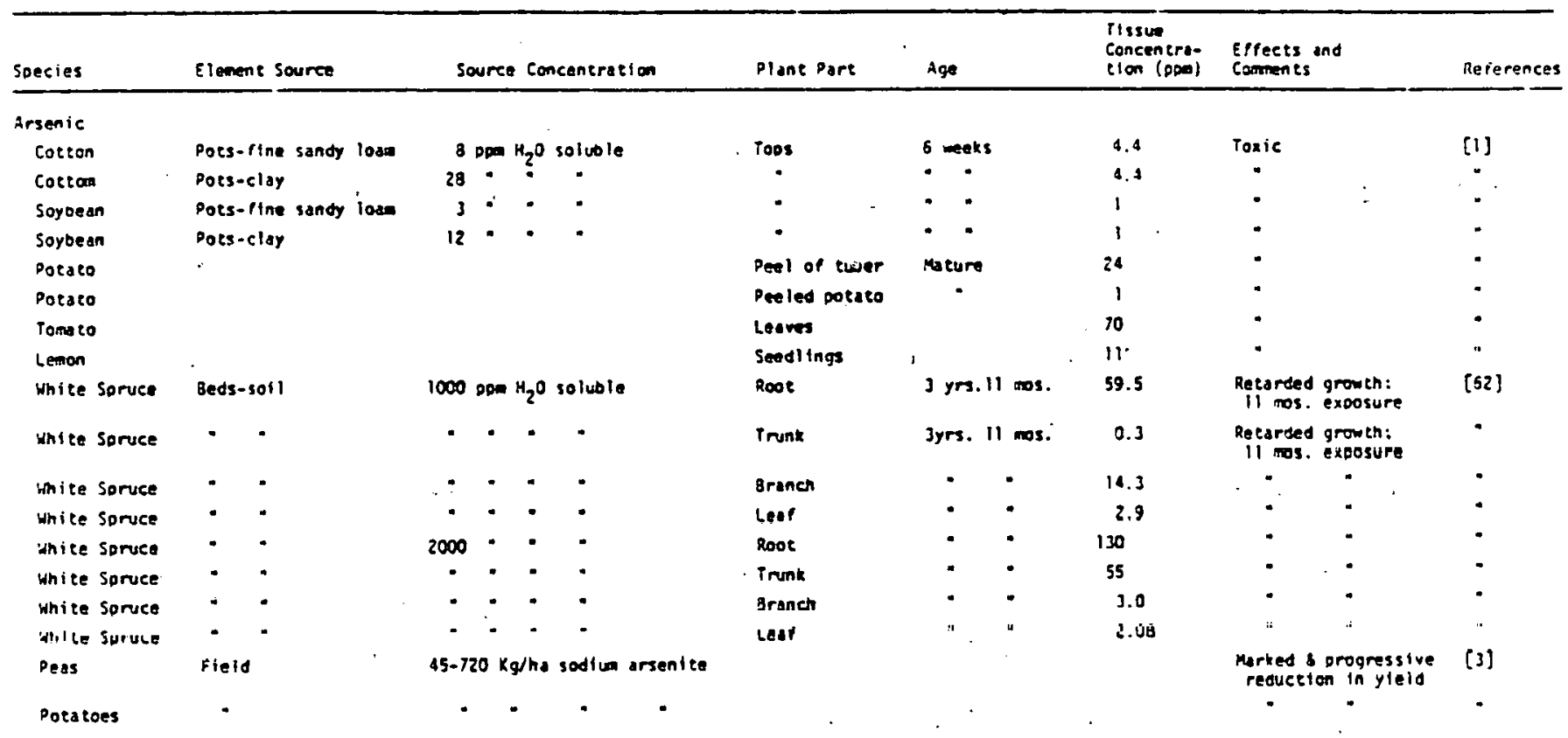

- Oaca In enis table are primartly from table ol in Ovorak. However. additiondi informotion on the behavior and toxictetes of these elements have been added.

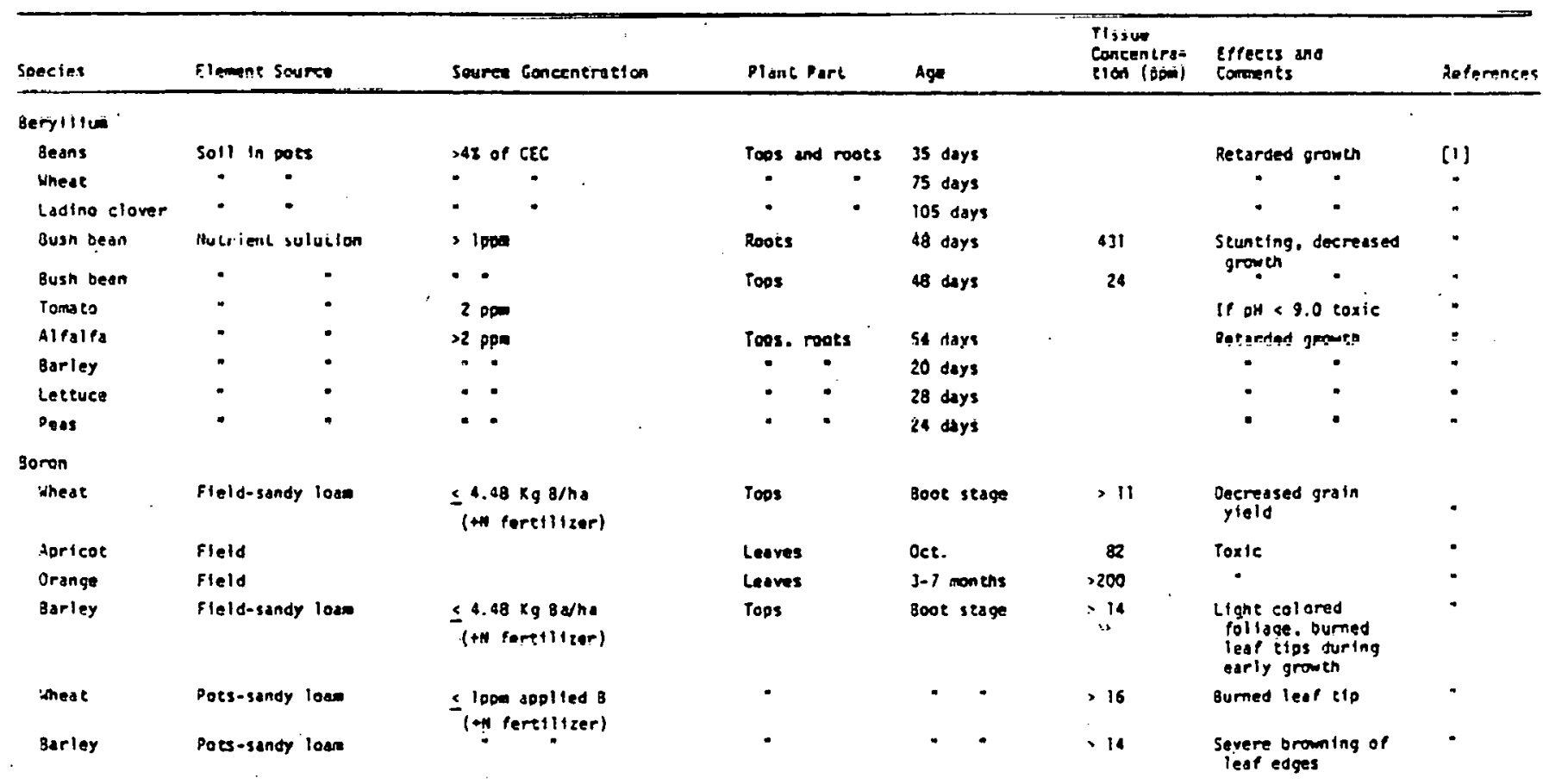


Table Al (continued)

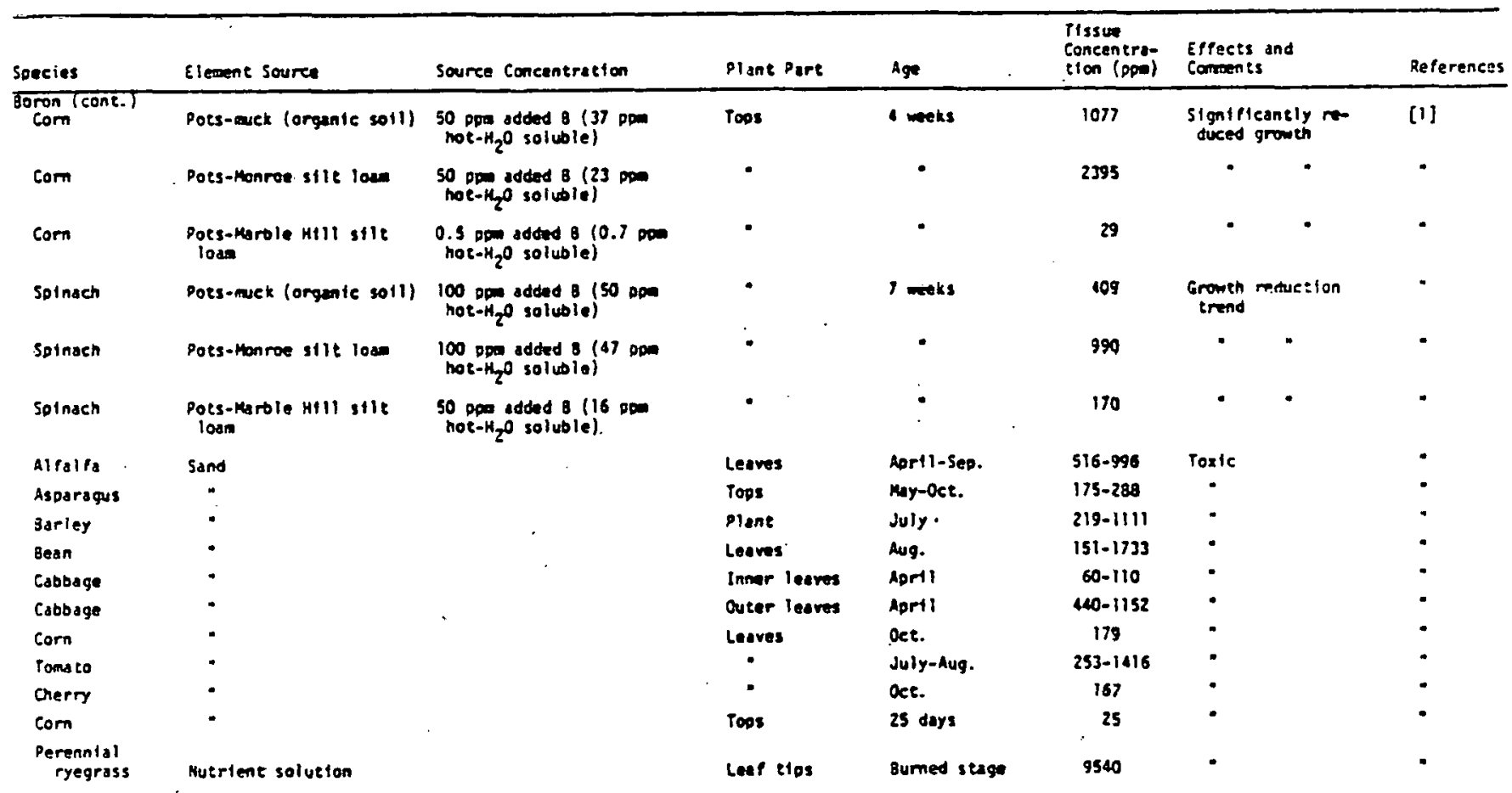

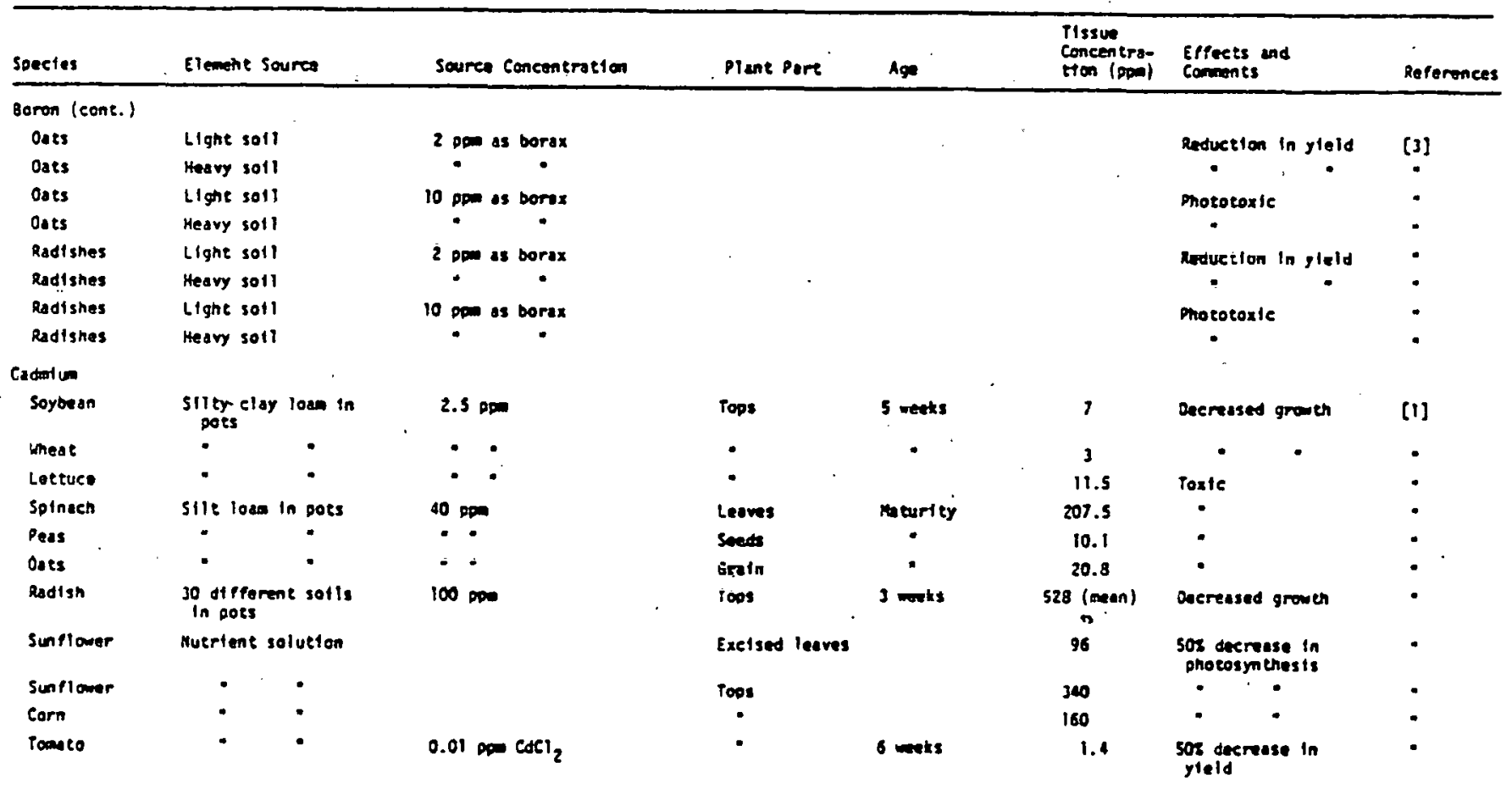


Table Al (continued)

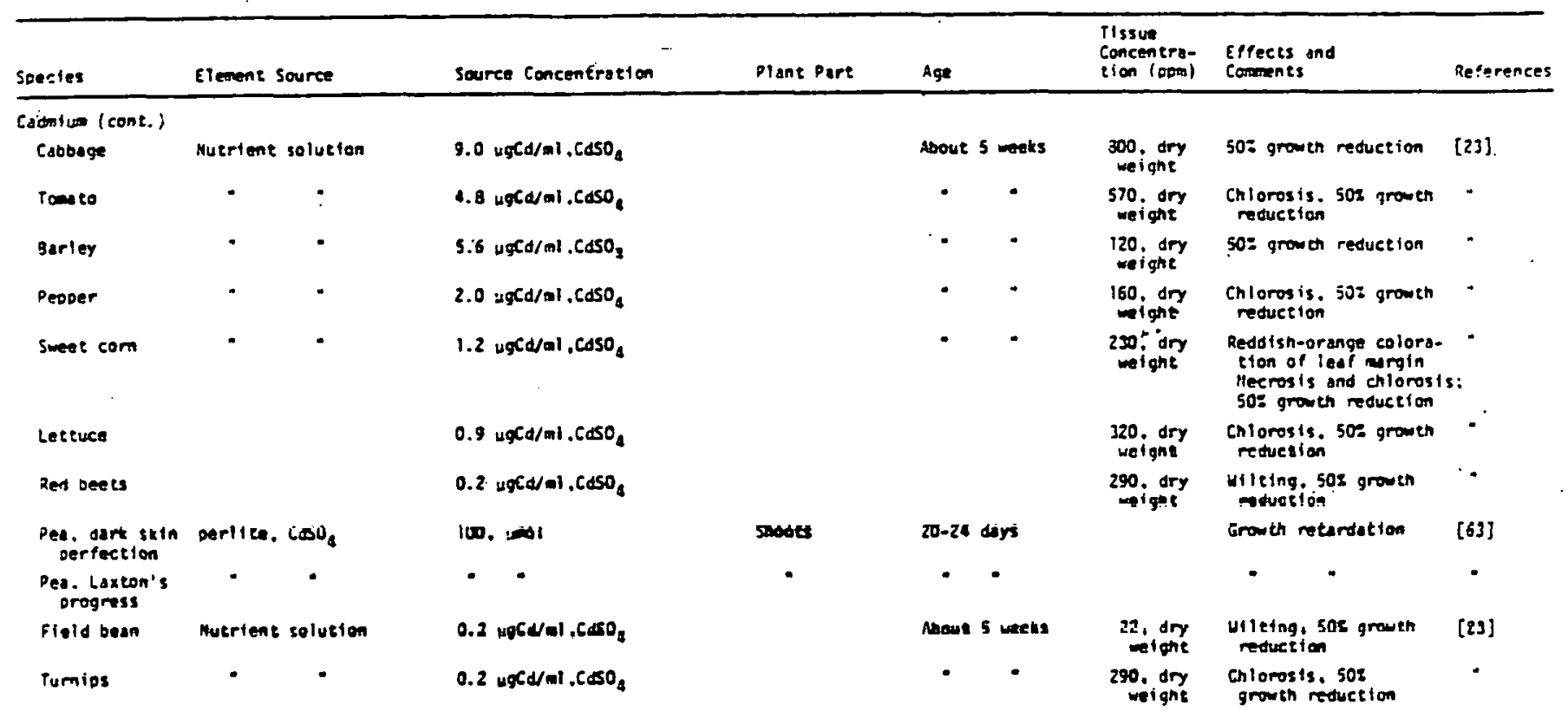

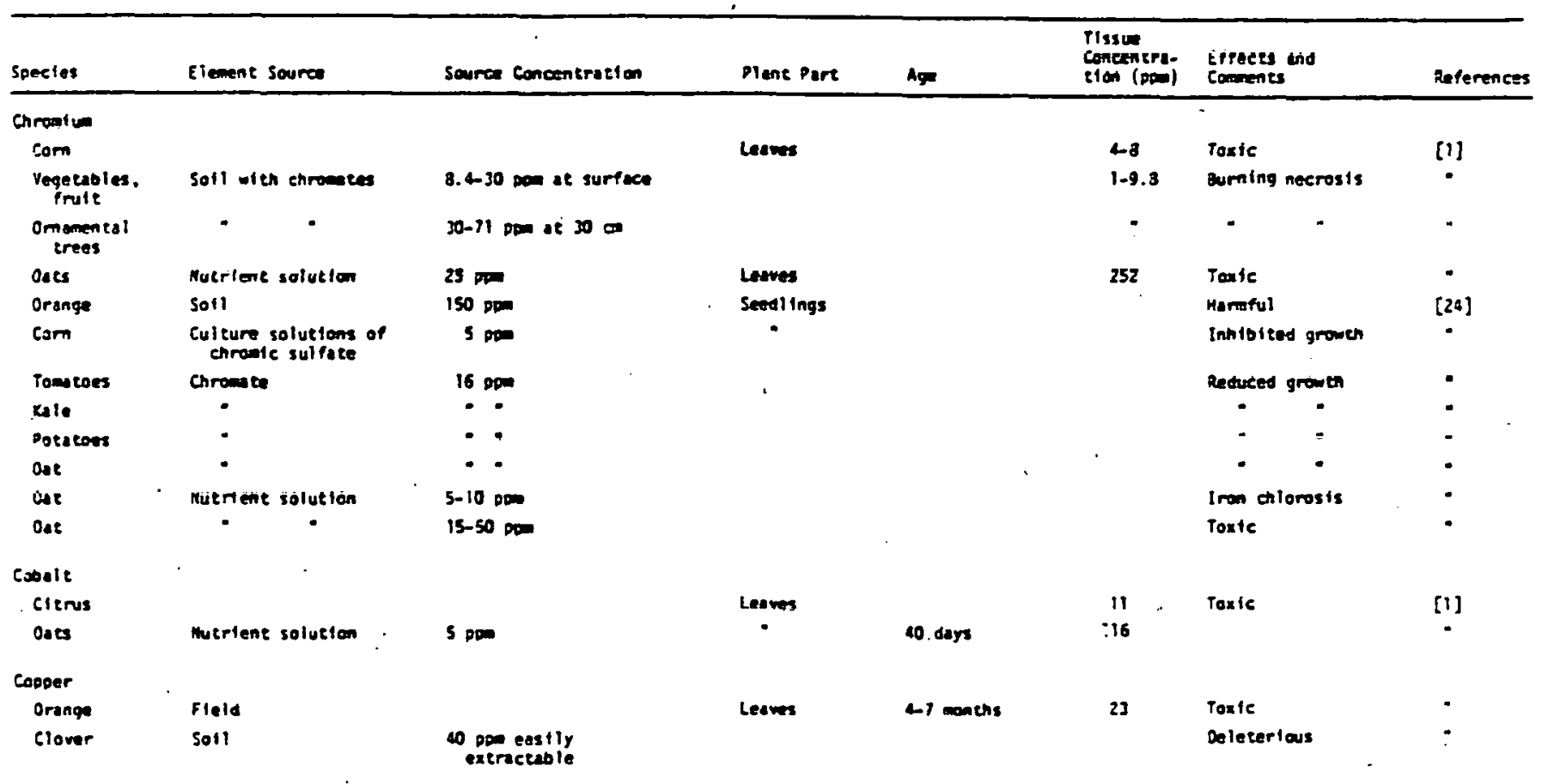


Table Al (continued)

\begin{tabular}{|c|c|c|c|c|c|c|c|}
\hline Soecies & Elemene Source & Souree Conemtration & Pent Part & Aga & $\begin{array}{l}\text { Tissue } \\
\text { Concentra: } \\
\text { lion (poo) }\end{array}$ & $\begin{array}{l}\text { Efiects and = } \\
\text { Coments }\end{array}$ & References \\
\hline \multicolumn{8}{|l|}{ Cooper (con't.) } \\
\hline Citrus & Very sandy sotl & $3 \mid 50$ ope toul Cu' & & & & If soll DH $\leq 5$. Coric & [1] \\
\hline $\begin{array}{c}\text { Soinach. gladt- } \\
\text { olas }\end{array}$ & Sot1 & 98-130 po exchangatele $\mathrm{Cu}$ & & & & If soil on $4.5-4.7$ & $\cdot$ \\
\hline Mllet & Sand & & Leoves & Seediling seage & $0.73-1.23$ & Toxte & $\bullet$ \\
\hline Hillee & Sand & & Leaves & Yegetative stage & $1.32-2.90$ & Toxic & $\cdot$ \\
\hline Mlliet & Sand & & Lesves & Flowering stago & $1.04-1.27$ & Toxic & $\bullet$ \\
\hline Barley & Hutrient solution & $0.5 \mathrm{Dom}$ & & & & Deereased growen & $\cdot$ \\
\hline Snaobeans & Soll-fleld & is opm EDTA-extractable & & & & Reductions in yield & [13] \\
\hline \multicolumn{8}{|l|}{ Fluorine } \\
\hline Bean & Nof anended soil & & Laeves & & 410 & Toxie & [1] \\
\hline Winter wheat & Amended sotl & $1000-1500 \mathrm{pos} F$ & & & & $\begin{array}{l}40-6 \text { : decrease in } \\
\text { yleid }\end{array}$ & - \\
\hline Tons to & $\begin{array}{l}\text { Field funtigation } \\
\text { chambers }\end{array}$ & $\begin{array}{l}0.6 \text { ug } \mathrm{F}^{3}\left(\mathrm{~d}^{3}\left(0^{\circ} .73 \mathrm{pob}\right)\right. \\
\text { coneinuous } 1 \mathrm{y}\end{array}$ & Leaves & Marvest-93 days & 193.7 & $\begin{array}{l}\text { No risual symotoms or } \\
\text { effects on yieid }\end{array}$ & - \\
\hline Seañ & $\begin{array}{l}\text { Fleld funigation } \\
\text { ehamoers }\end{array}$ & $\begin{array}{l}0.6 \text { ug } f / \mathrm{m}^{3}(0.73 \mathrm{ppb}) \\
\text { conet nuous ly }\end{array}$ & $\begin{array}{l}\text { Leoves } \\
\text { Stems } \\
\text { ronole pods } \\
\text { Pod musks } \\
\text { Seeds. }\end{array}$ & Harvest -43 days & $\begin{array}{l}71.1 \\
5.8 \\
4.6 \\
3.5 \\
5.7\end{array}$ & $\begin{array}{l}\text { No rfsual symotcms. } \\
\text { no decrease in } \\
\text { vegetat1 ve grower. } \\
\text { and boen a } 20 \% \text { de- } \\
\text { crease in numer } \\
\text { and a } 25: \text { decrease } \\
\text { in fresh wt. of } \\
\text { mintetsble poos }\end{array}$ & " \\
\hline Aople & Alr & $1.5000 F$ & Leaves & & $72 \cdot 234$ & Toxic & $\cdot$ \\
\hline Blueberry & Alr & $1.5000 \mathrm{~F}$ & Leeves & & $34-53$ & $\bullet$ & $\cdot$ \\
\hline - Englisn elm & AIr & $1.5000 \mathrm{~F}$ & Leaves? & & $18-265$ & $\bullet$ & - \\
\hline
\end{tabular}

\begin{tabular}{|c|c|c|c|c|c|c|c|}
\hline Soectes - & Elenent Soures & Soure Concantration & Plane Part & Age & $\begin{array}{l}\text { Plssue } \\
\text { - Concentre- } \\
\text { tion (ppe) }\end{array}$ & $\begin{array}{l}\text { Effects and } \\
\text { Cominents }\end{array}$ & Ruferences \\
\hline \multicolumn{8}{|l|}{ Floorine (con't.) } \\
\hline Laret & Atr & $1.5000 F$ & meedles & & $53-62$ & Taxie & [1] \\
\hline Apole & Atr & $3.0900 \mathrm{~F}$ & Leaves & & $79-259$ & $\bullet$ & $\bullet$ \\
\hline Sluebery & Atr & 5.0 pod F & Leaves & & $22-103$ & $\cdot$ & $\bullet$ \\
\hline English $\bullet$ It & Alr & $5.0 \mathrm{000} F$ & Leaves & & 72 & $\cdot$ & $\cdot$ \\
\hline Lareh (PIme) & Alp & $5.0 \mathrm{pob} F$ & Miditat & & $73-147$ & $\cdot$ & $\cdot$ \\
\hline Apple & Alr & 10.0 opt $F$ & Leaves & & $142-194$ & - & $\cdot$ \\
\hline Sluebarty & Afr & 10.0 & Leaves & & 64 & " & $\bullet$ \\
\hline Englfsh el & Air & $10.0000 F$ & Leaves & & 160 & - & $\cdot$ \\
\hline Lareh (PIna) & Afr & $10.0000 \mathrm{~F}$ & meedies & & 108 & - & • \\
\hline $\begin{array}{l}\text { Contfors (Ever. } \\
\text { greens) }\end{array}$ & Air & 0.5 ug $F / m^{3}, 10$ days & Meadies & At nesedle & & $\bullet$ & $\cdot$ \\
\hline Buchweet & Exoosed to HF gas & & Leaves & & $594-1389$ & on sete soll. toxic & $\bullet$ \\
\hline Sineet Com & HF in atr & 2-3 ppo F , & Leaves (washed) & neture & $48-491$ & Toxte & $\bullet$ \\
\hline $\begin{array}{l}\text { Susceetiole } \\
\text { soectes }\end{array}$ & AIr. I day & $3-4$ ug F/o & 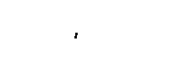 & & & Mreshold Ilafe & $\cdot$ \\
\hline $\begin{array}{l}\text { Suscepetble } \\
\text { specles }\end{array}$ & Afr. $\Rightarrow 1$ noneh & 0.5 g $5 / a^{3}$ & & & 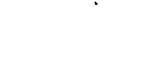 & - & • \\
\hline $\begin{array}{l}\text { Intarmedtately } \\
\text { suacape 1bie } \\
\text { soactes }\end{array}$ & Alr. I day & $=10 \mathrm{\mu g} F / \mathrm{a}^{3}$ & & & . & $\cdot$ & $\cdot$ \\
\hline $\begin{array}{l}\text { Ineonodiarely } \\
\text { susceptible } \\
\text { spactes }\end{array}$ & Alr. $\geq 1$ monen & $1-3$ ug $5 / a^{3}$ & & & & $\bullet$ & $\bullet$ \\
\hline
\end{tabular}


Table Al (continued)

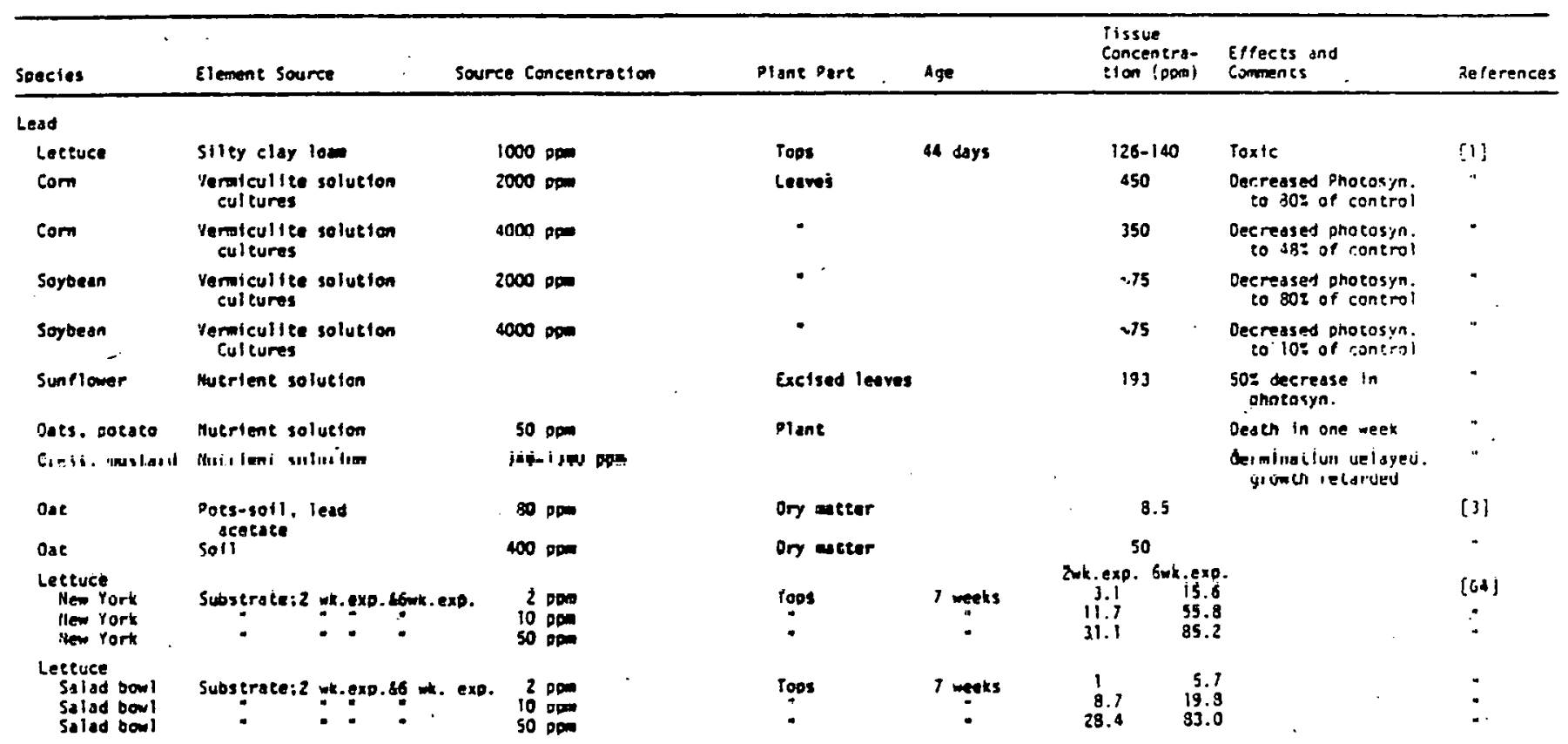

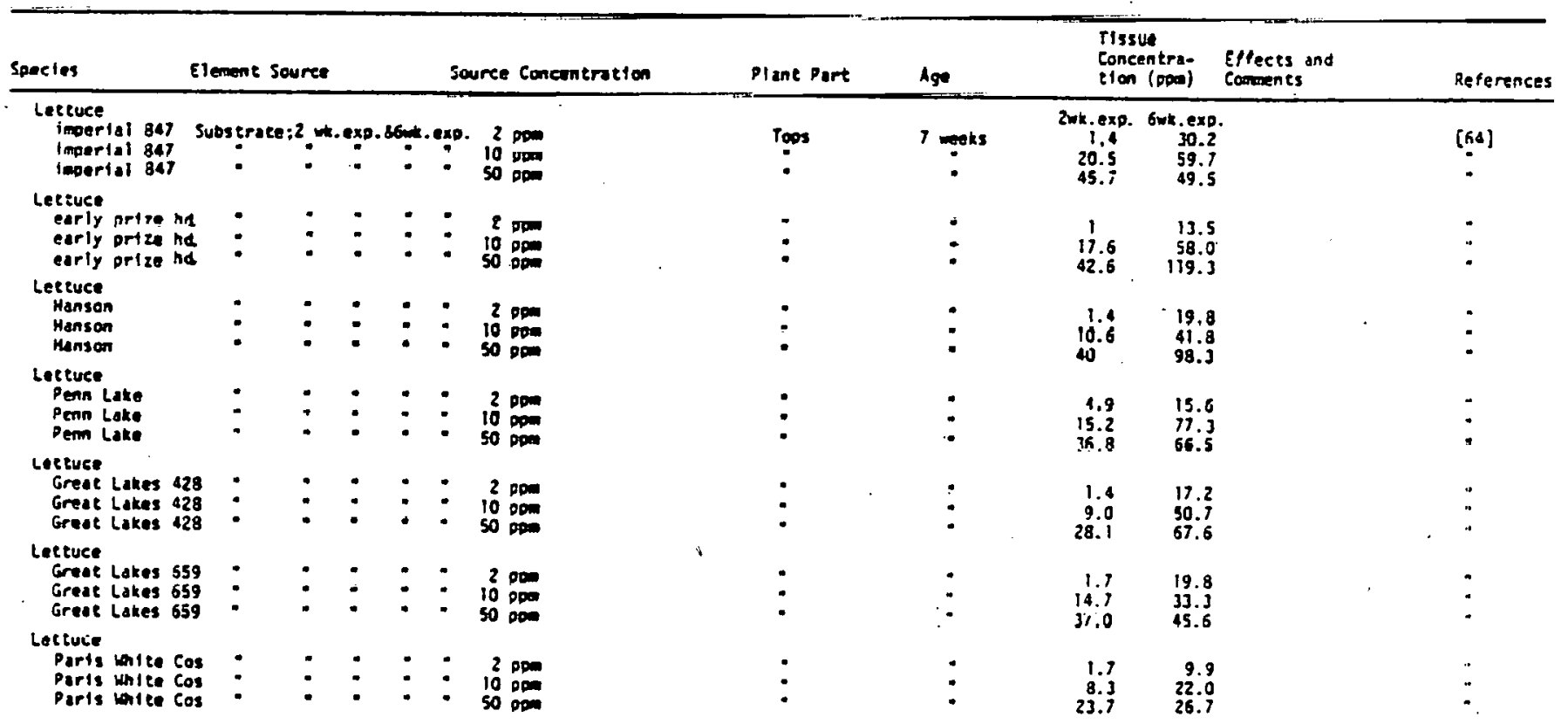


Table Al (continued)

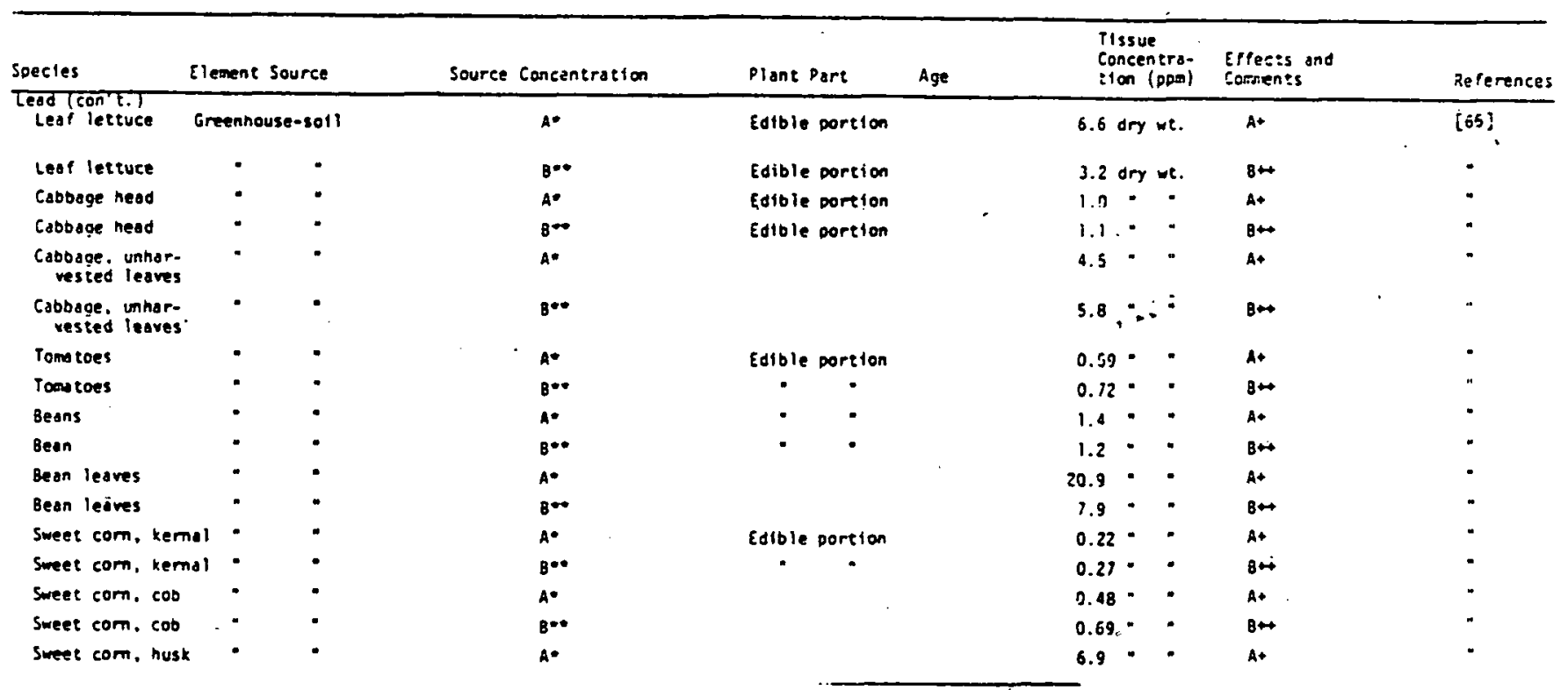

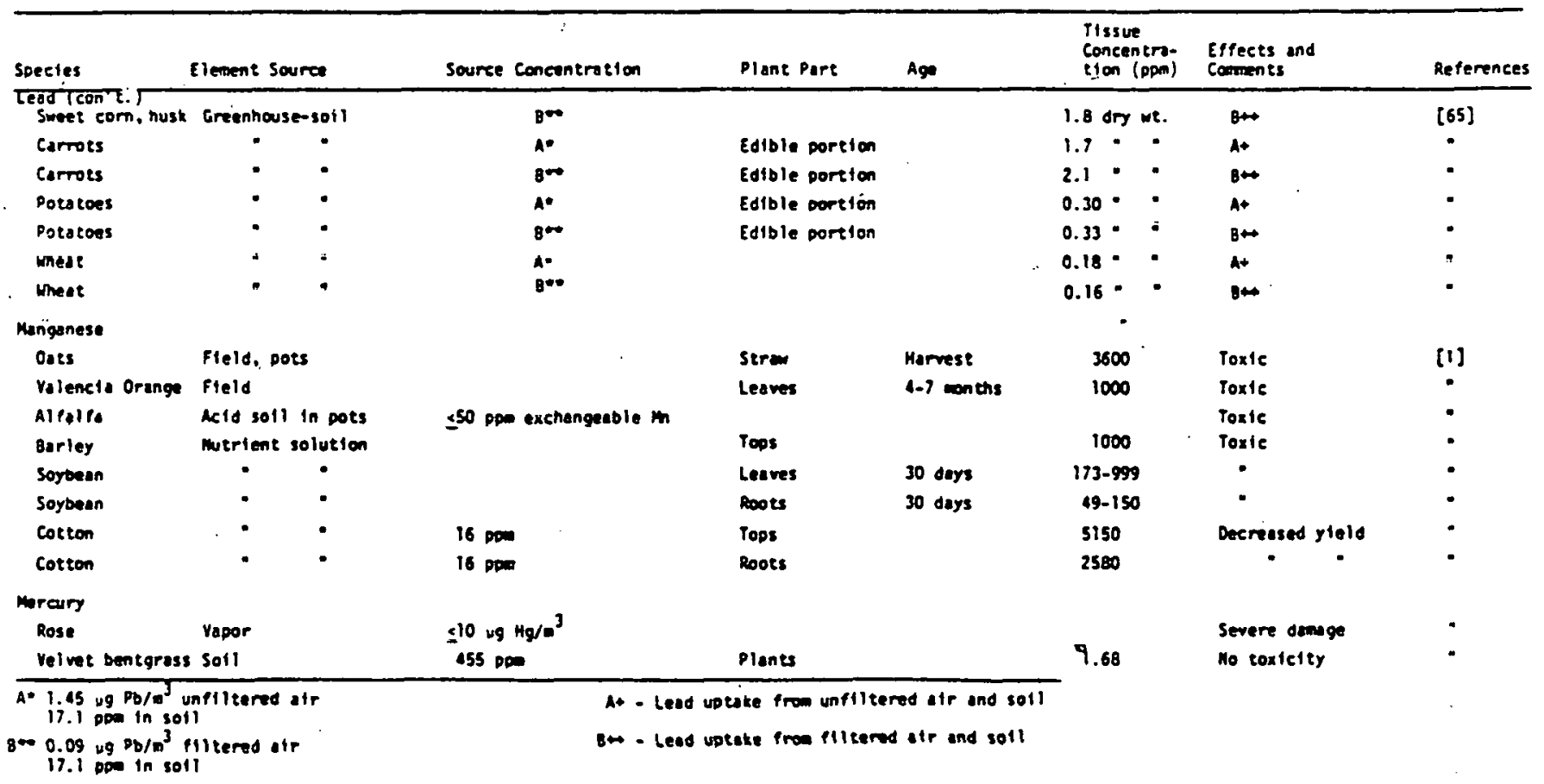


Table Al (continued)

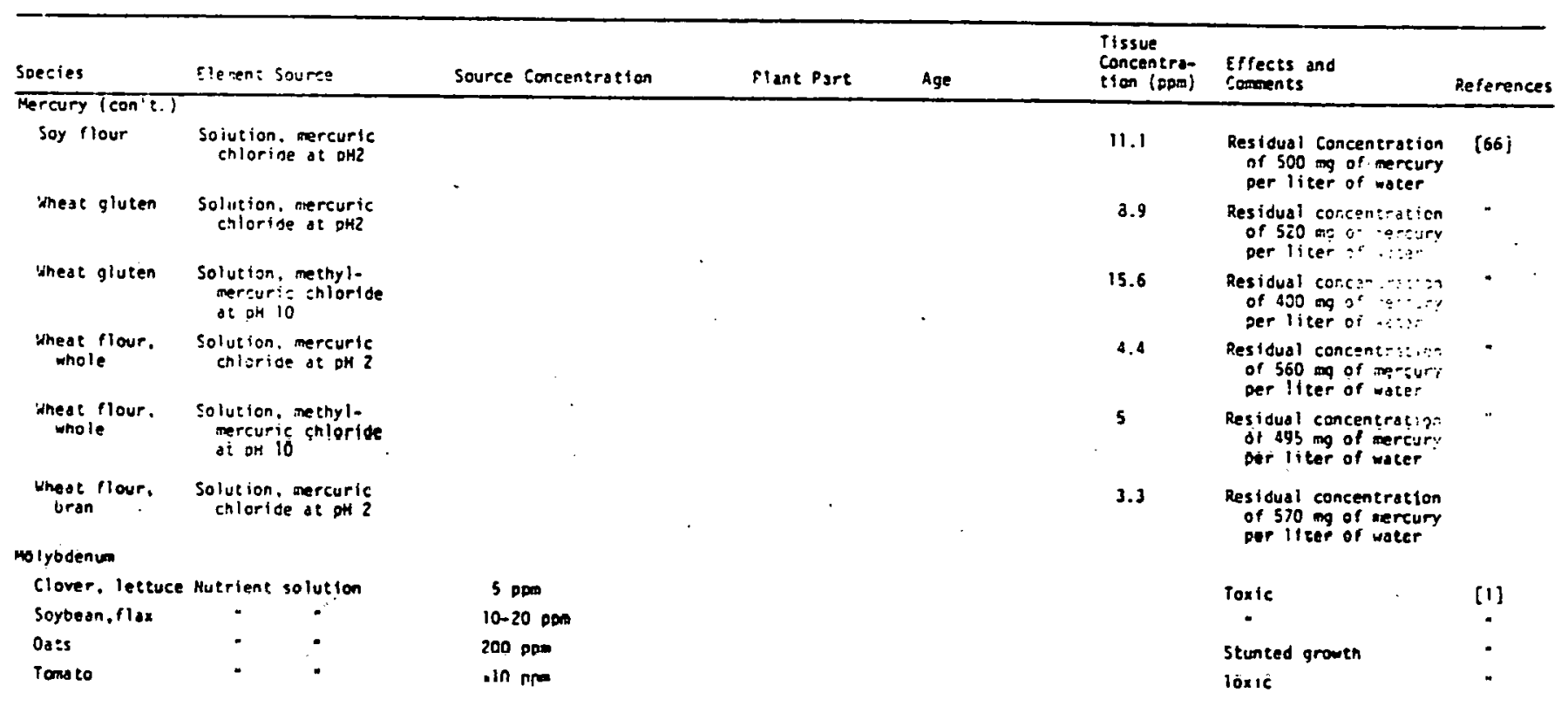

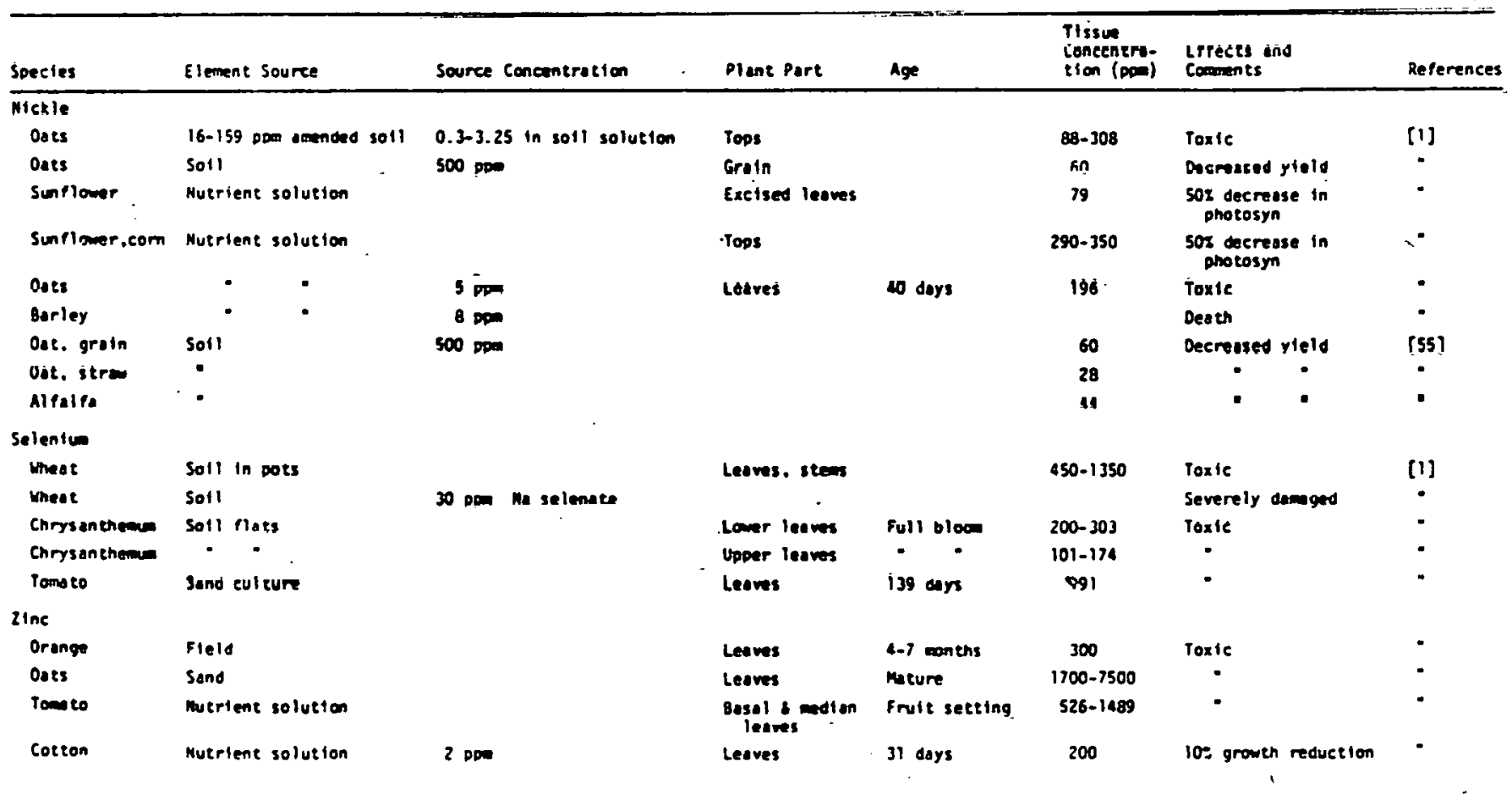


Table Al (continued)

\begin{tabular}{|c|c|c|c|c|c|c|c|}
\hline Soecies & Elemene Source & Source Concentration & Plane rare & Age & $\begin{array}{l}\text { Tissue } \\
\text { Concentra: } \\
\text { ticn (epa) }\end{array}$ & $\begin{array}{l}\text { Effects and } \\
\text { fomments }\end{array}$ & At ference: \\
\hline \multicolumn{8}{|l|}{ Enc (Eont.) } \\
\hline Mony species & & & & & $200-2000$ & $\begin{array}{l}\text { Decreased yield. } \\
\text { toxieity syonions }\end{array}$ & $-[1]$ \\
\hline Lettuce & $\begin{array}{l}\text { Pots-soll. ecettc } \\
\text { ocid extractuble }\end{array}$ & $60 \mathrm{Dom}$ & & & & Inntbltion of growth & [3] \\
\hline \multicolumn{8}{|l|}{ Vansdium } \\
\hline Alfalfo & Send & 500 D000 1 & , & & & Decreased arowen & [1] \\
\hline $\begin{array}{l}\text { Soybean. flax } \\
\text { peas }\end{array}$ & Nutrient solution. & $2.5-5.0 \mathrm{ppm}$ & & & & Toxic & $\bullet$ \\
\hline Many spectes, & Soil & $10-1.250$ & $\cdot$ & & & $\begin{array}{l}\text { Toxic, depending on } \\
\text { chemical form ond } \\
\text { plane spectes }\end{array}$ & [59] \\
\hline Certain olonts & $\begin{array}{l}\text { Solution culture } \mathrm{V} \text { as } \\
\mathrm{NH}_{4} \mathrm{HO}_{3}\end{array}$ & 0.5 & & & & Toxie & \\
\hline
\end{tabular}




\section{Appendix $B$ to Chapter 4}

In this Appendix, the adverse biologic implications of selected trace elements in animals is discussed. Some of the conclusions on trace element toxicosis derived from the general and industrial environments along with laborztory experiments will be reviewed. Information on actual dose response relationships are given in Table $B T$ at the end of this Appendix. Although controlled experiments generally provide a base for assessing differeri: chemical states of a potential toxicant in various animal systems, direct chronic manifestations rarely are studied. The toxicity data mostly are expressed as variations of the lethal dose (e.g., lethal dose for $50 \%$ of the population) rather than the dose at which toxic symptoms are manifested. More data are needed on the long-term effects since trace element toxicity usually occurs after an element has accumulated in human and animal systems over extended periods of time. Hence, dose-response relationships reported by the maximum allowable concentration at which toxic symptoms do not occur would be more releyant than by lethal dose.

Arsenic has not been proven to be essential for animals. The element is among the potentially toxic metals which stimulate biologic systems when present in minute quantities. As a stimulant, arsenic is no longer used in human medicine but it has retained some use in veterinary medicine, according to Luckey [68]. Most humans and animals have small amounts of arsenic present in all tissues, with highest accumulations in muscle. A cross section of the published data on the different tissue concentrations of arsenic in humans, livestock and wildlife can be found in an Environmental Protection Agency report [73] 
on several environmental pollutants.

Unlike most trace metals, arsenic can be absorbed through the skin; absorption through the skin is facilitated by arsenic compounds which are lipid soluble. In general, man and other animals are capable of fully absorbing inhaled arsenic compounds from the lung and mucous membranes of the respiratory tract. Usually negatively. charged and soluble compounds of arsenic are well absorbed from the gastrointestinal tract. Arsenic accumulates with age in animal tissues such as the aorta and spleen. The element also binds to tissue protein in bone, skin, hair and nails. These sites also may retain arsenic for long time periods.

To some degree most chemical forms of arsenic are toxic. Elemental arsenic essentially is nonpoisonous when ingested; although, elemental arsenic can be biotransformed into the toxic compound arsenic trioxide. Inorganic arsenic compounds are generally more toxic than organic arsenic compounds. Chronic exposure to arsenic compounds such as arsenic trioxide dust or vapors may result in general weakness, muscular aching, perforation of nasal septum, tremors, ulcerations in the digestive tract and/or functional disturbances in the peripheral nervous system. In laboratory animals, chronic inhalation at subtoxic levels of the volatile arsine arsenous hydride caused the separation of the oxygen carrier hemoglobin from the red blood cells.

A synergism has been noted between arsenic and lead. The toxicity of lead and arsenic apparently increases when both metals are present at the same biologic site. In contrast, small concentrations of arsenic and selenium together in biologic tissue seem to interact. to attenuate the toxicity of each other. Epidemiological and experimental evidence are in complete contradiction for establishing arsenic 
as a carcinogen. Many medical investigators have correlated arsenic with various respiratory cancers and skin cancer. Most laboratory experiments have unsuccessfully produced cancer in test animals. The toxic properties of arsenic and its compounds along with experimental and epidemiologic data have been reviewed by Venugopal and Luckey [74], Sittig [75] and Smith [76].

Barium stimulates all types of muscles, but it is uncertain if mammalians require the element for growth or biologic functions. The heart is the major muscle in which barium exerts its stimulatory effects. Compounds of the element, such as barium chloride, no longer are used in human medicine as a muscle stimulant because of their toxic properties. Barium is present in all animals. About 66 percent of the barium in the adult human body is deposited in the bones.

Following ingestion, soluble barium salts easily permeate the intestinal mucous membranes and rapidly flow in and disappear out of the blood. Inhaled barium salts are retained in the lungs and the aorta, and accumulation in these sites increases with age. Analys is of human soft tissue further revealed the presence of barium in the adrenal glands, thyroid, male and female reproductive organs, urinary bladder and muscle. Barium has been found in newborn infants, indicating that ionic barium crosses the placental and mamary barriers. Also, the analyzed concentrations in infant tissues were higher than in adult tissue. Animal metabolism of barium closely resembles that of calcium. But barium deposition in bone differs from that of calclum in that barfum deposition is faster and irreversible. 
Soluble barium compounds are very toxic while insoluble barium compounds generally are nontoxic. Ingested barium salts have a long stimulating effect on the heart and other muscles. One symptom of barium poisoning is increased blood pressure. Inhaled barium dust and compounds have been associated with benign pneumoconiosis, a chronic reaction of the fibrous lung tissue, bronchitis and reduced respiratory capacity. The metabolism and toxicity of barium has been reviewed by Venugopal and Luckey [ 74$]$.

Beryllium is not an essential micronutrient for man or other animals. Furthermore, beryllium neither stimulates biologic tissue nor serves any biologic function. Beryllium is believed to accumulate with age since the body is not known to have a homeostatic regulatory mechanism for efficiently eliminating the element.

Both soluble and insoluble beryllium compounds are toxic. Acute beryllium disease is mainly from soluble beryllium compounds. Acute pneumonitis, a condition marked by inflamation of the 1ung, can be brought on by the inhalation of soluble beryllium sulfate and beryllium chloride. Insoluble beryllium compounds cause chronic beryllium disease in that these forms accumulate for long periods of time once laid down in biologic tissue. Metallic beryllium and beryllium oxide are insoluble beryllium compounds that can produce berylliosis, a chronic disease that generally produces lesions in the lungs. Also, berylliosis is a complex systemic disease that may affect all organs of the body except those in the pelvic region. Beryllium intoxication can range from mild to severe, and even 
fatal, depending on the level and duration of exposure. The mode of entry is usually inhalation. Inhaled soluble beryllium compounds are transiently retained in the lungs, and ultimately absorbed into the blood stream for distribution mainly to bones and kidneys. The lungs retain insoluble beryllium compounds for long periods of time. Toxicity is latent, whereby the effects of beryllium poisoning in humans and animals may become apparent following years of chronic exposure. Upon penetration into living tissue beryllium potentiates cellular death. Some characteristic but complex mechanisms of action in beryllium toxicity are inhibition in the activity of a number of enzymes; inhibition in the synthes is of nuclear proteins and DNA. Laboratory experiments using test animals have shown beryllium to interferewith the differentiation of developing embryonic tissue. Experimental studies have shown beryllium carcinogenicity in marmals; however, epidemiologic data on beryllium carcinogenicity is sparse and therefore not conclusive for establishing the element as a carcinogen. Venugopal and Luckey [74] comprehensively reviewed beryllium toxicity in humans and animals. Additional discussions on the subject can be found in Dvorak et al. and Sittig.

Boron, a nonmetal, does not appear to have a micronutrient role in animal life forms. In general, most boron compounds are moderately toxic to man and animals when either inhaled or ingested. The dusts of boric acid and boron oxide are described as being moderately toxic, while the dusts of some other boron compounds are regarded as minor irritants. Little or no boron accumulates in the human body foliowing the normal dietary intake of boron enhanced fruits and vegetables. 
Most evidence of boron toxicosis have come from medicinal or occupational exposure. Infants have been accidently poisoned from oral or topical boric acid treatment. Irrespective of the route of administration, the more severe cases of boric acid poisoning have resulted in shedding of the skin, kidney failure and death from circulatory collapse and shock. Because of its proven toxic effects, boric acid is used seldom as a medicinal remedy. Borax is capable of penetrating through the skin and producing symptoms similar to boric acid poisoning. Chronic toxicity has been documented among workers engaged in the parkaging of boron fertilizers. Complaints among these workers were poor appetite, nausea and loss of weight. One is referred to sittig for further information on the toxicity of boron compounds.

Cadmium is highly toxic and its presence in any cell should be minimized. There is little conclusive evidence indicating that cadmium facilitates any biologic function. Venugopal and Luckey [74] state that cadmium is not required for any enzymatic reactions, but they suggest that cadmium nonspecifically actiyates some enzymes. Small amounts of cadmium accumulate with age in the tissues of all animals. For mammals, in particular, the retention in some organs is long and the body excretion is low. The long biologic half-life of cadmium in mamals suggest that these species lack a homeostatic excretory mechanism for cadmium.

Cadmium has an electron configuration similar to the essential trace metal zinc; and competes with this metal in a number of zincmetalleoproteins and zinc-metallœenzmes. Cadmium can irreversibly bind to active storage sites in the metalleoproteins and metalleoenzymes thereby disrupting the normal metabolism of zinc. Based on these actions, 
cadmium is classified as a competitive antagonist. Exposure to cadmium tends to increase zinc levels in organs having an affinity for zinc. This may be due to the greater burden placed on the body to more efficiently take up zinc and in turn counteract the action of cadmium.

In addition to zinc, antagonistic interactions of cadmium with copper and iron have been found to occur in mammalian tissue and to cause symptoms similar to copper deficiency and iron deficiency. Experiments on animals have indicated that cadmium interferes with copper metabolism by reducing its absorption, consequently reducing the activity of ceruloplasim (the protein that transports the copper plasma fraction of the blood). Reduced copper concentrations in plasma and liver along with bone malformations from cadmium induced copper deficiency have been found in rats, lambs and pregnant ewes. Cadmium intoxication in rats, chicks and Japanese quails inhibited iron absorption in these species and subsequently inhibited hemoglobin formation.

Cadmium absorption from ingested cadmium compounds is low in manmals. Humans absorb approximately $6 \%$ and animals in general $2 \%$, according to Friberg and associates [77.]. One must not be misled by these low absorption rates since cadmium accumulation in biologic tissue continues and retention persists for long time periods regardless of the body burden. In the literature on toxic substances [78] it is indicated that cadmium ingested in quantities. only 3 to 13 times greater than the present average intake rates may have unquestioned chronic toxicity leading to serious consequences. Following absorption from the gastrointestinal tract, ingested cadmium accumulates mainly in kidney and liver with appreciable amounts taken up by the male 
reproductive organs. Inhaled cadmium compounds are absorbed more effectively than the ingested forms. Friberg and associates state that observations on humans indicated that the absorption rate may be $25-50 \%$ following the inhalation of cadmium.' Studies carried out on experimental animals revealed an absorption rate between $10-40 \%$.

Following prolonged exposure via inhalation or ingestion the liver and the kidneys will contain $50-75 \%$ of the total body burden of cadmium. In humans, the critical organ is the kidney. Once the concentration of cadmium reaches a critical level in the renal cortex (system of blood vessels and secretory ducts) renal tubular damage occurs. The renal tubules are the functional elements of the kidneys. Upon renal tubular failure, there is decreased reabsorption of zinc and the excretion of cadmium and serum protein in the urine. Among Swedish and British workers exposed to cadmium dust for more than 15 years, proteinuria and kidney stones were detected. An abnomality in calcium metabolism by the kidneys subsequent to the renal tubular defect was considered as the likely cause for the renal stone formation.

The predictable consequences of chronic cadmium poisoning may be damage to the kidneys followed by proteinuria, renal stone formation and osteomalacia (softening of the bones from calcium deficiency); damage to the lungs by the developilent of emphysema and bronchitis; and damage to the olfactory nerve. Experimental studies on rats have shown that cadmium can give rise to malignant tumors. However, the carcinogenic effects of cadmium in humans is inconclusive. Cadmium is carried through the food chain and therefore is found in all animal tissues. The Environmental Protection Agency [73] has prepared a 
recent survey report on the cadmium content in the biologic tissues of humans, livestock and wildlife. Friberg and associates have completed a lengthy review on cadmium toxicity. The effects of cadmium toxicity have also been discussed by Leh and Lak [7], Venugopal and Luckey, Dvorak et al. and Sittig. Specific topics on cadmium in animal systems can be found in the discussions on cadmium metabolism by Fox [78] . and chronic cadmium toxicity by Piscator [79].

Chromium is an essential micronutrient for most animal life forms. In several mammalian systems, including man, chromium is an important factor for maintaining normal health. Trivalent chromium is an active ingredient in the glucose tolerance factor, and is required for optimal glucose utilization. Chromium, is not an essential component of any metalleoenzymes. Furthermore, chromium does not serve as a specific enzyme activator.

The intestinal absorption of trivalent chromium is low. The acid of the stomach favors the trivalent chromium state, and reduces the more soluble and toxic hexayalent chromium saits to the trivalent form. Studies on humans revealed gastrointestinal absorption of trivalent chromium to be less than $1 \%$ regardless of the dietary chromium status and intake. Inhaled chromium salts deposited in the lungs have poor solubility in pulmonary fluids and accumulate in the lungs with age.

Chromium and its compounds have a very low order of toxictty in animal systems. According to Venugopal and Luckey [81], it appears mammalians are able to withstand levels of chromium in the order of 100-200 times their total body burden. Information on chromium toxicity has been obtained mainly from occupational exposure. Chromium metal 
is believed to be nontoxic. All airborne chromium compounds are potentially toxic in sufficiently high concentrations. The major health problems are associated with hexavalent chromium compounds which are irritant and corrosive. Hexavalent chromium compounds may be absorbed by ingestion, inhalation and through the skin. Among industrial workers exposed to chromium compounds and chronic acid mist, these substances have been documented as causing irritation and ulceration of the skin, perforation of the nasal septum and irritation of the respiratory tract. The prolonged inhalation of chromate dust has been reported as resulting in such manifestations as congestion of the larynx, polyps of the upper respiratory tract, tracheitis, emphysema and chronic bronchitis. The available epidemiologic data indicate an increased incidence of lung cancer among workers exposed to hexavalent chromium.

Toxicity in fish is fairly high from hexavalent chromium. Sittig pointed out that 1.2-5.0 ppm is fatal to most fish species. The behavior and effects of chromium in humans and animal systems has been reviewed by a National Academy of Science panel [24] and by Schroeder [81] in one of his air quality monographs. Venugopal and Luckey [75, 82], Smith [83] and Sittig also have summarized the actions of chromium on different animal life forms.

Cobalt is an essential micronutrient in animals. Its only known function is in the snythes is of vitamin $B_{12}$, cobalamin, which in turn, has an important role in the synthesis of the red blood cells. In animals, the cobalt absorbed through inhalation or inyestion usually distributes through the tissues. There generally is poor retention of cobalt in animals. 
Humans absorb cobalt poorly from the intestine. Absorption efficiency from the gastrointestinal tract largely is dependent on the dose. Large doses are absorbed poorly while small doses, such as $30-50 \mu \mathrm{g} / \mathrm{Kg}$, are absorbed readily from the gastrointestinal tract. The absorption of cobalt occurs at the proximal and distal regions of the intestine. The cobalt that is not absorbed from the intestine remains stored in the intestinal mucosa. Removal subsequently is through desquamation of the epithelium cells. Following inhalation, metallic cobalt powder and cobalt salts are absorbed slowly.

A mutual antagonistic relationship exists between cobalt and iron as both metals have similar electron structures. From studies on rats, it was found that the antagonism between the two metals results from the competition for transport sites across the intestinal membranes. Test results using chicks, further confirmed the mutual antagonism, in that, the substitution of cobalt for iron in the diet results in a greater degree of iron deficient anemia when the chicks were fed equal amounts of cobalt-iron supplemented feed.

Mammals have an effective homeostatic regulatory mechanism for cobalt in both absorption and excretion. However, cumulative toxicity may result when the level of cobalt absorption exceeds that of its excretion. The animal species and health of the species along with the cobalt compound and dose are interdependent factors in cobalt toxicity. In general, cobalt aerosols are potential irritants since these forms may cause severe lung damage in humans and animals. Low levels of water soluble cobalt compounds can be tolerated by mammais. As an example, safe daily dosages by milligrams per kilogram body weight for 
man, sheep and cattle are reported as $2-7,3-10$, and $1-20$ respectively. It has been suggested that some soluble cobalt salts might undergo biotransformation to a toxic form following gastrointestinal absorption. If this is true, small doses may be toxic.

Cobalt salts once used as actives in beer were partly blamed for cardiac failure in heavy beer inkers. Based on evidence from animal experiments and human exposure, cobalt poisoning also has been connected with increased red blood cell production; myocardiopathy accompanied by pericardial effusion; goiters caused by the blocking of iodine uptake by the thyroid gland; interference with metabolic functions in the liver. For additional information on cobalt toxicity one is referred to Venugopal and Luckey [74]; Leh and Lak [7]; and Hill [83].

Copper, in man and animals, has a long established history as being essential for normal health and longevity. Copper is a constituent of several metalleoproteins, and a requirement for iron utilization, connective tissue formation, pigmentation and energy production. The numal adult human body contains $80-150 \mathrm{mg}$ of copper. Approximately one-third of this amount is distributed in muscle tissue; however, more copper is retained in brain, liver and kidneys than any other soft tissue. Most human diets already are overabundant in copper in terms of metabolic requirements. Less than one-half of dietary copper is absorbed, and only about 5 percent of absorbed copper actually is utilized.

The absorption of ingested copper is mainly from the small intestine. 
The chemical form of the copper compound influences copper absorption. Ionic copper is easily absorbed while water ins'oluble copper salts are poorly absorbed. Inhaled copper dust is gradualiy absorbed from the lungs with part of these particles remaining in the lung tissues. An efficient homeostatic mechanism for copper exists in man, animals and birds. The biliary system is the major excretory pathway in these rife species. Based on the finding that the copper concentration in the human fetus is ten times greater than the standard amount in the liver of adults, copper easily crosses the placenta.

Copper toxicity is augmented by negatively charged ions such as arsenite and chromate, but impeded by sufficient dietary intake of zinc, iron, molybdate and sulfate. There is a wide spread between beneficial and toxic copper intake in mamals but not in fish. Among mammals, ruminants are more susceptible to copper toxicity than nonruminants. Sheep are particularly susceptible to copper poisoning as are young calyes. Nausea, yomiting, epigastric pain, yellow watery diarrhea and dizziness are general signs of chronic copper poisoning in mammals. More advanced signs of chronic copper poisoning are jaundice, hemoglobinuria (the presence of hemoglobin in the urine), and green stools, saliva and yomitus.

Observations following the ingestion of copper feed reveal pigs can tolerate diets containing $250 \mathrm{ppm}$-copper. Symptoms of mild chronic copper poisoning became apparent following sustained dietary intake of feed containing $500 \mathrm{ppm}$ copper. Chronic copper poisoning in sheep results from a sustained copper dietary level of 10-15 ppm. In sheep passive accumulation of copper may occur whereby toxicosis may become evident in two weeks or more than a year. Copper intoxication in calves results from maintained copper dietary levels of 
20-125 ppm. Water concentrations ranging from 0.01-1.7 ppm copper are toxic to fish. The maximum allowable concentration was observed to be $0.03-0.08 \mathrm{ppm}$ copper for the flathead minnow. Copper concentrations of $0.02 \mathrm{ppm}$ can inhibit the growth of the chinook salmon fry.

Tissue analyses on livestock and laboratory animals that died from copper intoxication showed degenerative changes in the brain, kidneys, liver and spleen. Congestive lungs and cardial hemorrhage also were evident. Copper accumulation in sheep, calf, swine and poultry liver may have deleterious affects onhumans when these animal species are raised for human consumption. It has been estimated that baby food prepared from animal liver having $550 \mathrm{ppm}$ copper would contain 28 grams of copper per serving.

Most data on chronic copper toxicity in humans has been inferred from animal tests. From tests on nonruminants, such as pigs, it reasonably could be concluded that with adequate dietary intake of zinc. iron, molybdenum and selenium 10-15 times the level of copper normally present in the diet could be tolerated. A continuous increase in copper contents of food and water may at some future time present a problem in the clinical management of Wilson's disease; an inherited degenerative disorder of copper metabolism in humans. Some epidemiologic evidence supports a casual relationship between copper and cancer. Vineyard workers exposed to copper sulfate fungicide initially were found to have fibrosis of the lungs. More recently, carcinogeneses of the lung and liver have been diagnosed in these workers. For a more indepth discussion of copper in man and animals see the document by the National Academy of Science [28] and the review by Venugopal 
and Luckey [74]. Brief reviews can be found in David et a]. [52] and Sittig.

Fluorine is beneficial for the prevention of dental caries, however a requirement for fluorine has not been established in man. Inorganic fluoride compounds are rapidly absorbed from the small intestine. These substances are distributed throughout the body with as much as 95 percent of the body burden stored in skeletal and dental tissues. The more biologically active growing bones seem more easily to incorporate fluoride. Ingested fluoride mostly is excreted through the kidneys within a few hours. Fish protein is high in fluoride having concentrations ranging from 20 to 760 milligrams fluoride per kilogram protein.

Controlled animal experiments on livestock have shown that cattle are very susceptible to fluoride poisoning whereas poultry are essentially insensitive. Safe dietary levels for cows have been estimated as ranging from 30-50 ppm for soluble fluoride, and 60-100 ppm for insoluble flouride. Among poultry, safe dietary levels of soluble fluoride have been reported as ranging from 150-300 ppm for chickens and 300-400 ppm for turkeys. Sheep and swine are less sensitive than cows as these animal species can tolerate long-term ingestion of diets containing 70-100 ppm soluble fluoride. Chronic fluoride toxicity in livestock is manifested by abnormal tooth development and changes in bone structure marked by stiffness and lameness.

Fluoride intoxication in humans has resulted in dental lesions, calcification of the ligaments, abnormal growth of the outer bone tissues and lameness. Workers in the cryolite (fluoride sodium and aluminum) industry have been found to develop a crippling fluorosis following several years of exposure to more than $20 \mathrm{mg} /$ day of fluoride. Navia et al. [84], Fleischer et al. [30] and Dvorak et al. have reviewed the biologic effects of fluorine in man and animals. 
Lead is not essential for nutrition. According to Venugopal and Luckey [74] lead is stimulatory, since lead has been found to enhance protein synthesis, DNA synthesis, cell replication, red blood corpuscle production and respiration. Lead can be found in all organs and tissues of mammals. Under normal conditions, whereby the homeostatic. mechanism functions properly, the concentration of lead in bone increases with age whereas the concentration in tissue is relatively stable.

In man, the rate of absorption of dietary lead is infiuenced mainly by the dosage. However, this has not been found to be true for such animal species as rabbit, sheep and cattle. From a literature review by Chisolm [85], approximately 90 percent of dietary lead passes through the gastrointestinal tract without being absorbed, and normally the small amount that is absorbed also is excreted or deposited in bone. However, as the level of intake of lead increases the rate of absorption may increase and exceed the rate at which the homeostatic mechanisms can function properly. Less lead may be excreted or absorbed in bone whereby the levels of lead in soft tissue may rise.

When the continuous intake of lead by both inhalation and ingestion is less than $1 \mathrm{mg} /$ day, approximately 90 percent of the absorbed lead in humaris is localized eventually in the skeleton. Lead especially accumulates in areas of active hone formation. Immobilization of exchangeable lead from bone becomes less of a possibility with the passage of time, except during bone fracture, chronic infection and metabolic disturbance. There are indications that lead and cadmium exhibit similar behavior in their deposition and mobilization from bone. Lead is absorbed more efficiently when the mode of entry is inhalation. About 90 percent 
of the inhaled lead particles are absorbed rapidly by the lungs and the respiratory tract, and approximately 50 percent of this initial amount is trapped in the upper respiratory tract and eventually swallowed. For the remainder of the inhaled lead which is deposited in the lungs, particles ranging in size from 0.01 to 0.1 microns are absorbed from the lungs.

Lead has a high toxicologic potential in mammals owing to poor homeostatic mechanisms for regulating diffusible lead forms. The maximum allowable daily dosage of lead for man is $1 \mathrm{mg} / \mathrm{day}$. Any level of exposure slightly beyond the maximum allowable dosage may offset the capacity of the regulatory system to handle lead. Soluble lead forms will then be retained in soft tissues rather than optimally excreted and deposited in bone in small amounts. Lead poisoning is established by the concentrations of the element in soft tissues such as the brain, kidneys and liver. Since lead poisoning is cumulative, chronic subtoxic levels are potentially hazardous. Also, lead toxicity symptoms brought on by subtoxic lead levels may not become apparent for several years following the initial time of exposure. As summarized by Venugopal and Luckey [74], chronic subtoxic levels cause insidious changes in cell permeability of the testes, liver, kidneys and brain; over time there may be a reduction or complete breakdown of their functions. These authors succinctly describe the chronic toxic effects of lead as impaiment of renal functions and reproduction, impaired immunity, reduced development of blood cells and reduced function of the central and peripheral nervous systems. Visible effects are given as premature loss of teeth, nonspecific intellectual 
and psychological deterioration along with reduced growth and longevity.

The literature on toxic effects of lead indicates that horses are more susceptible than cattle to lead toxicity and can tolerate in their diet no more than $1 \mathrm{mg} \mathrm{Pb} / \mathrm{Kg}$ of body welght; calves are less tolerant than cows to high chronic dietary intake of lead. Neonatal man and animals are susceptible to a degenerative disease of the brain called lead encephalopathy, which is brought about by the transfer of lead from the mother to the newborn through the maternal milk. The mothers are unaffected; hence the mammary glands function poorly as a barrier to the transfer of milk from the mother to the lactating newborn. Children and pregnant women are susceptible to lead toxicity when sustained on diets that are deficient in iron, calcium and phosphorous. Low dietary intake of calcium and phosphorus increases the available sites in soft tissue for the uptake of diffusible mobile lead. Studies on rats indicate iron deficiency and lead intoxication synergistically impair hematopoiesis, that is, the formation and production of blood cells. Reviews on lead metabolism and toxicity that are recommended include those by Chisolm [85], Smith [86], Venugopal and Luckey [74], Goyer and Chicolm [87], deWerk Neat [88], Hallenbeck [89] and Sittig.

Manganese is an essential. trace element for growth, skeleton development and reproduction in all animals; birds require more manganese than mammals. Manganese is the least toxic of all the essential trace metals. Ingested manganese is absorbed poorly under normal body states, this being due partly to the intestinal manganese 
concentration in addition to the level and form of manganese in the body. Iron deficiency aids in increasing manganese absorption from the gastrointestinal tract as does insufficient dietary intake of the essential micronutrient calcium and phosphorus. Manganese salts deposited in the lungs are slowly and continuously absorbed at a rate dependent on the body storage of manganese. A portion of the inhaled manganese enters the gastrointestinal tract by swallowed particles from the upper respiratory tract when mixed with saliva. Also, an unspecified amount of the manganese absorbed from the lung is carried to the gastrointestinal tract and subsequently absorbed.

For most animal species approximately 40 percent of the total body burden of manganese is in the bone marrow; the tissues of the kidneys are additional sites where manganese retention can be found in humans. The homeostatic mechanism of the body regulates manganese excretion more than absorption so that under steady states manganese does not accumulate with age. However, elevated intake and retention may cause a breakdown in the homeostatic excretory mechanism.

Manganese ferrous ions are not very toxic to aquatic organisms, but such manganese compounds are very toxic to birds and mammals when present in large concentration, according to Schroeder [66]. Most epidemiologic data on chronic manganese intoxication have come from occupational exposure. Workers exposed for a few months to dust particles of manganese oxides have developed a pulmonary pneumonitis called manganic pneumonia. The disease hüs a high mortality rate. Manganism or chronfc manganese puisoning is a disease of the 
central nervous system brought on by the inhalation or ingestion of toxic levels of manganese compounds such as manganese oxides over a period of a few months to a couple of years. Some people are more susceptible to manganism than others. Manganism has both psychologic and neurologic manifestations and may result in partial or total disability when counteractive procedures are not enacted. The disease is reversible if diagnosed early and the individual is removed from the source of exposure. Other detrimental effects characteristic of manganism are kidney failure, cirrliusis of the liver, loss of appetite, fatigue, sexual impotence and anemia.

Data on exposure to atmospheric manganese is limited. Atmospheric manganese has been statistically correlated with several types of respiratory diseases, heart disease and cancers. A study in Saude, Norway conducted at the start of industrial activity and extended over fifteen years indicated the incidence of pneumococcal pneumonia was eight times greater for the residents of this area than for the general population. One given explanation was that airborne manganese reduced the resistance in the lung to the invasion of pneumococci bacteria thus facilitating the development of pneumococcal pneumonia. Clinical symptoms of coughing, colds and upper respiratory infections were observed among school children living near a ferromanganese plant in Kanazawa, Japan. However, these symptoms were absent in school children residing a distance of five miles from the plant.

From the report by Schroeder, ambient air levels of manganese may be indirectly toxic. As an example, manganous sulfate catalyses the chemical reaction whereby sulphuric acid is formed. The literature 
on manganese metabolism has been reviewed by Leach [70]. Yenugopal and Luckey [74], Matrone et al. [42] and Sittig have detailed reviews on manganese metabolism and toxicity in man and animals.

Mercury is not essential for man or animals. As shown by controlled animal experiments, mercury may stimulate some biochemical activities when administered at very low levels. However, the observed results indicate a very narrow spread between stimulative and toxic effects. Mercury is retained in tissues and therefore classified as a cumulative poison. Man and animals apparently lack a homeostatic mechanism for regulating and excreting mercury.

Mercury absorption in man and animals is influenced greatiy by the chemical form of the element. Inorganic mercurous compounds are absorbed poorly from the gastrointestinal tract due to the low solubility of these mercurial forms. Experimental studies reveal greater gastrointestinal absorption for organic mercurials than inorganic mercuric compounds. As cited by Yenugopal and Luckey [74], the estimated absorption factor is about $30 \%$ of inorganic mercuric mercury in goats and about $60 \%$ of organic mercury in lactating cows. In his experimental work on humans, Miettinen [ 90 ] found that in 4-5 days about $6 \%$ of the administered dietary organic mercury and about $85 \%$ of the dietary inorganic mercurtc mercury were excreted mostly in feces. Methyl mercury was the chemical form of the organic mercury compound. The biologic half-time of the remaining dietary mercuria?s (time by which the remaining substances are reduced to one-haif) was about 76 days for the methyl mercury and about 42 days for the inorganic mercury. 
For elemental mercury inhalation is the most effective route. As determined in a number of animal studies, elemental mercury vapor easily passes across the alveolar membranes (gaseous exchange sites in the lungs) and quickly transfers to the blood. The percentage of inhaled elemental mercury vapor ranges from 75 to $100 \%$ for laboratory animals and 75 to $85 \%$ for humans, as cited in Friberg and Vostal [91 ]. In general, aersols of inorganic mercury compounds are absorbed poorly through the lungs. It is believed that relatively large inhaled particles are brought up rapidly in mucous from the upper airways. Particles deposited in the peripheral lungs, however, may remain for several days to a year. The available information concerning the uptake and absorption of inhaled organic mercury as monomethyl mercury or dimethyl mercury reveal poisoning in man and animals may occur following the inhalation of these mercurials. From experimental studies on animals, it has been concluded that the placenta acts as a barrier against the transfer of inorganic mercuric substances to the fetus. Monomethyl mercury reaches the fetus. Based on the depidemiologic data for Japan, healthy females exposed to methyl mercury may give birth to offspring with brain damage. Monomethyl mercury also is passed through the mother's milk to the lactating newborn.

Biotransformation of mercury from one chemical state to another is possible in humans and animals. Inhaled elemental mercury vapor is transformed to inorganic mercuric mercury in the blood. However, a quantity of elemental mercury remains in the blood for part of one circulatory cycle and enroute in circulating blood readily diffuses 
across the cerebral vessels into the brain. Mercury taken up by the brain is excreted slowly. Results of experimental studies seem to indicate that mercuric mercury may be volatilized in the lungs and exhaled as mercury vapor. Although in these studies volatilization of mercury occurred in the lungs, only a small amount of the riscury was eliminated by exhalation.

Mercury and its compounds generally have definite distribution patterns in biologic tissues. The toxicologic characteristics of different forms of mercury that enter humans and animals therefore are related to the biologic sites in which the mercury is stored. Inorganic mercury as elemental mercury when inhaled is stored largely in brain tissues, thus producing its adverse effect on the central nervous system. The kidneys and liver are the critical sites for the accumulation of inorganic mercurous and mercuric mercurials. With these mercurials, damages to kidney and liver tissues progress before neurological symptoms are evident. Organic mercurials, particularly methyl mercury, readily cross cellular membranes and are taken up by liver and kidney but primarily tend to accumulate in the brain and affect the central nervous system.

Mercury intoxication in humans and animals historically has been a problem in industrial areas. It is well recognized that humans and varieties of fish species have been affected adversely by mercury contamination from industrial sources. Further evident is mercurial poisoning of humans, livestock and wildlife from seeds treated with mercurial fungicides. From such outbreaks of mercury poisoning, knowledge has been gained on the toxic symptoms of chronic and 
acute mercury intoxication. However, insufficient information still exists on mercury as an environmental contaminant from trace amounts of the element released into the atmosphere. Goldwater [6] indicates that the medical profession presently lacks reliable diagnostic tests for determining human responses to mercury in the environment. Furthermore, many investigators warn that the question still is unresolved as to the maximum allowable daily intake of mercury in assessing the risks of genetic or fetal damages. One is recommended to see D'Itri and D'Itri [5] for a historical introduction into mercury as a human health hazard. The mercury problem in the environment has been summarized by Goldwater. For detailed discussions on the actions of mercury in human and animál systems one is referred to the publication prepared by D'Itri. [47] and the one by Friberg and Vostal. Venugopal and Luckey [74], Goldwater and Clarkson [92], and Sittig have done reviews on mercury, including mercury toxicity.

Molybdenum is an essential element in man and animals. Several metalleoenzymes have molybdenum as a constituent. The minimum requirement of molybdenum in man is small but the exact. amount is unknown: It has been suggested that $0.1-0.3 \mathrm{mg}$ Mo/day may be adequate for man. The absorption of molybdenum is dependent on the chemical form of the element. Soluble hexavalent molybdenum compounds are absorbed to a high degree from the gastrointestinal tract. Less soluhle molybdenum compounds such as molybdenum trioxide and calcium molybdate are absorbed poorly from the digestive tract; however, when fed in high doses to guinea pigs and rabbits, molybdenum trioxide and calcium 
molybdate are absorbed fairly well. In humans, approximately $25-75 \%$ of dietary molybdenum is abosrbed from the gastrointestinal tract. The efficiency of absorption of molybdenum from the lungs is high for most molybdenum compounds. Molybdenum metabolism is similar to copper and sulfur, as derived from animal data. Under normal conditions, noiybdenum is retained temporarily in the mammalian body and ultimately excreted in the urine. Also, molybdenum does not accumulate with age in memmals.

Molybdenum is believed to have a low order of toxicity in humans. Information on the toxicity of molybdenum in humans mainly has come from the U.S.S.R. Sittig mentions specifically two reports, one suggests that inhalation of molydenum dusts may lead to pulmonary disorders such as pneunoconiosis (a chronic hardening of pulmonary fibrous tissues). The other report from the U.S.S.R. has identified people living in an area with high dietary intake of molybednum (10-15 mg/day) as having an increased prevalence of joint disorders that resemble gout, as well as increased blood levels of uric acid and increased excretton of uric acid in urine; while people living in an area of lower dietary intake of molybdenum were described as being asymptomatic.

Ruminants are highly susceptible to molybdenum toxicity. Venugopal and Luckey [74] indicate that animals susceptible to molybdenum poisoning, by order of decreasing tolerance, are horses, pigs, rats, rabbits, guinea pigs, sheep and cattle. Cattle may die of molybdenosis after grazing in pastures containing 20-100 ppm molybdenum. (dry weight), while pigs may tolerate 1000 ppm molybdenum in feed. Chronic molybdenosis in animals is marked by loss of weight, loss of appetite, 
anemia, deficient lactation, male sterility, decrease in bone substance and bone-joint abnormalities. Inhalation of readily soluble molybdenum trioxide dust is toxic to rabbits. Dietary supplements such as copper, sulfate or sulfur containing amino acids have been shown to inhibit molybdenum toxicity. The adverse effects of molybdenum in man and animals have been reviewed by Sittig and Venugopal and Luckey [74].

Nickel is considered an essential micronutrient for animals as nickel deficiency in rats, swine and chicks resulted in suboptimal growth. An unequivocal role for nickel has not been establisher in humans. Nickel is believed to activate some enzymes, but an enzyme has not been identified for which nickel is a constituent. Trace amounts of the element have been found in the tissues of the human fetus and newborns. Humans do not accumulate nickel with age. Very little variation in serum nickel levels were found in sixteen different animal specles tested. Hence, an efficient homeostatic excretory mechanism exists for nickel in humans and animals.

Nickel is firmly bound in foods and for this reason most dietary nickel is not absorbed from the gastrointestinal tract but is excreted in the feces. In comparison, nickel in drinking water has a higher absorption rate. Following inhalation, a large proportion of gaseous nickel is deposited in the pulmonary parenchyma (functional tissues of the lung). Approximately $25 \%$ of inhaled nickel dust is deposited in the pulmonary parenchyma and about $50 \%$ reaches the bronchial mucosa and is swept upward with mucous and swallowed. Inhaled nickel salts are retained in the pulmonary tissues. 
Dietary nickel has a low order of toxicity. As cited in Venugopal. and Luckey [74], chickens showed a reduction in growth when fed 900$1300 \mathrm{ppm}$ nickel as either nickel sulfate or nickel acetate. Also lowered retention of total nitrogen, calcium and phosphorous, in addition to reduced food intake and growth were detected in claves fed $1000 \mathrm{ppm}$ nickel. Nickel toxicity in humans mainly has resulted from occupational exposure to nickel and nickel compounds. Toxic effects ascribed to nickel are dermatitis, respiratory disorders, and cancers of the nose, sinus and lungs. Based on epidemiologic evidence, the dusts of nickel oxide and nickel chloride may produce pneumonitis. Nickel carbonyl may cause severe pneumonitis following a chronic eight hour exposure to $0.001 \mathrm{ppm}$ in air. Exposure to industrial nickel dusts has lead to nickel dermatitis in some workers.

From investigations on the induction of nickel carcinogenes is in experimental animals, insoluble nickel compounds such as nickel dust, nickel oxide, nickel sulfide, nickel carbonate, nickel carbonyl and nickelocene are potential carcinogens. Epidemiologic studies conducted in several European countries, Canada and the United States have identified 386 cases of pulmonary cancer and 123 cancers of the nasal cavities among workers in nickel refineries and factories, as compiled by the National Academy of Science [54]. In all of the cases nickel compounds were inferred as the primary carcinogens al though many of the workers also were exposed to the inhalation of arsenic, cobalt, chromium and other metals. Long term exposure to nickel compounds may also result in degenerative changes in heart muscles, liver and kidney tissues. Much of the available information. 
on the adverse biologic effects of nickel have been thoroughly examined in the National Academy of Science publicaton on nickel. More concise surveys on nickel toxicity can be found in Nielsen et a7. [55], Venugopal and Luckey [74], Schroeder [93] and Sittig.

Selenium is a required nutrient for several animal species; it being necessary for nomal growth and reproduction. The requirement for selenium in humans has yet to be substantiated. In the blood selenium is first incorporated in the plasma albumin from which it is distributed to the erythrocytes and globulins. Also, selenium is transported rapidly by the plasma albumin fraction of the blood to all tissues, particularly the liver, kidneys, bone, nails and hair. The retentive force of tissues for selenium depends on the amount entering and the existing body burden of the element. Venugopal and Luckey [74] indicate a specific homeostatic mechanism for selenium is nonexistent in animals. Excretory mechanisms prevent indirectly the accumulation of toxic levels of selenium, but within the capabilities of the vital processes to handle the metal. The path of excretion depends on the route of entry and is influenced by the chemical form of selenium along with the amount of intake. In addition to those external factors, excretion varies by animal species. As an example, ingested selenium is eliminated mainiy by feces in ruminants; urinary excretion is high in nonruminants.

In mamals, the inorganic metal selenides and elemental selenium are absorbed poorly from the gastrointestinal tract. In nonruminants passage across the intestinal cellular membranes is rapid and efficient 
for soluble selenium selinites and selenates; the same is true for seleniferous organic compounds. Not all of the ingested soluble selenium forms are absorbed from the gastrointestinal tract of ruminants. Some of the dietary selenium is reduced to insoluble selenium forms by rumen microorganisms and is passed through the gastrointestinal tract to be excreted in feces. Very. little information is available on the absorption of inhaled selenium compounds from the lungs; however, it is suggested that absorption is rapid.

Some researchers have shown that subacute doses of arsenic decrease the toxic effects of dietary selenium. Arsenic stimulates the biliary excretion of selenium in rats, thus preventing liver damage. The exact biochemical mechanism by which arsenic exerts its counter effect is unknown, but arsenic has an electron configuration similar to selenium. Although arsenic may counteract the toxicity of selenium, it must be recognized that arsenic itself is a toxicant. The poisonous quality of selenium may be augmented by arsenic if each element is present in sufficient quantity to induce toxicity. Contrasting the arsenicselenium relationship, various selenium forms have the property of being able to decrease the action of mercury poinsoning in rats. However, a synergism between some selenium compounds and certain mercuric salt.s has been obseryed.

Selenium is unusual in that the margin of safety between nutrient and toxic levels is very narrow. Venugopal and Luckey further note that the daily dietary requirement for selenium ends at about $0.01 \mathrm{ppm}$ while toxicity may begin at $0.4 \mathrm{ppm}$. Depending on the shemical form and the animal species, the estimated dietary threshold at which selenium may cause physiologic changes ranges from 0.03-0.4 ppm; 0.4-3.0 ppm 
may induce selenosis (selenium disease).

In humans, early symptoms of chronic selenium poisoning are depression, pallor, coated tongue, gastrointestinal disturbances and garlic odor of the breath. Prolonged exposure may lead to kidney, liver and spleen damage, hemolytic anemia and loss of hair and nails. Cases of organic selenosis have been observed among human populations living in selenifernus areas: Physical disorders typical of the affected populations were chronic dermatitis, fatigue, loss of appetite, spleen enlargement and degeneration of the liver. Chronic selenosis has been reported among families drinking well water from the Wasatch geologic formation in Utah; household pets also were affected. The water was estimated to contain $9 \mathrm{ppm}$ selenium. Once use of the aquifer was discontinued, mental alertness increased and other symptoms of chronic selenosis diminished. Outbreaks of selenium dermatitis-have occurred in Nebraska, South Dakota, North Dakota, Montana and Wyoming. Dietary selenfum from locally grown produce was identified as the irritant. The dermatitis ceased upon removal of selenium from the diet.

Sensitivity to selenium dioxide has been noted as a problem among industrial workers. Selenium dioxide in the presence of water forms selenious acid. Both selenium dioxide and selenious acid may be absorbed through the skin surface and thereby cause local inflamation of the skin. Other reports on selenium as an occupational hazard suggest that mild inhalation of selenium dusts, fumes and vapors may irritate the membranes of the eyes, throat and respiratory trace and thus cause discomfort, including tearing, nasal congestion sneezing and coughing. 
In livestock, the subacute and chronic forms of selenosis are referred to as aklali disease; acute selenosis is called blind staggers disease. Alkali disease has been found in livestock grazing on plants growing on certain range lands of the Great Plains and the Rocky Mountain region. Chronic organic toxicity in livestock may occur following the prolonged ingestion of plant matter containing 2-30 ppm selenium, while less extended consumption of $25-50 \mathrm{ppm}$ selenium is adequate to induce subacute organic toxicity. Common signs of alkali disease are loss of weight, weakness leading to lameness and irritability; biologic changes include degeneration of the liver, kidneys and cardiac muscle.

There remains little doubt that selenium is linked to teratogenesis. Based on experimental evidence and surveys of seleniferous regions, selenium produces physical abnormalities in the developing embryo. Selenium has been found to interfere with the normal development of the embryo in rats. The teratogenic effect of selenium is evident in the deformed embryos of chicks produced by hens from areas. Naturally having high selenium levels. From such areas, malformations of the eyes and hooves of the young borne by sheep and pigs were reported; also, calves were observed with deformed hooves. Selenium as a teratogen has been confirmed in humans from evidence of the unusual prevalence of miscarriages and the birth of infants with the congenital anomaly clubfoot among female workers exposed to selenite power.

The biologic effects of selenium has been discussed at length in a publication by the National Academy of Science [57]. Additional discussions on the toxicity of selenium can be found in venugopal and Luckey $[74,81]$, and Sittig. 
Vanadium has been proven essential for normal bone formation and growth in chicks and rats. On the basis of the results of laboratory experiments on these animals, it is inferred that vanadium is a necessary micronutrient for humans and animals. Vanadium absorption from the gastrointestinal tract is largely influenced by the solubility and ionic state of the vanadium compound. Absorption, in general, is poor for cationic vanadium forms but moderately good for water soluble anions. Vanadium taken up by the blood following the inhalation of vanadium compounds appears to be a more rapid process than transfer across the intestinal cellular membranes. Irrespective of the route of entry; absorbed vanadium is rapidly excreted in the urine. Vanadium does not appear to accumulate in either humans or animals.

In experimental animals, subtoxic levels of dietary vanadium induce loss of appetite and eventualiy lead to emaciation. Minute amounts of dietary vanadium aid in the development of chicks, but amounts beyond some beneficial level may have an adverse effect. Vanadium contamination in a feed supplement actually depressed chicken growth, as cited by Venugopal and Luckey [74]. Sittig found in his survey on vanadium toxicity that humans fed 4.5 to $40 \mathrm{mg}$ dietary vanadium for severa? weeks showed disease manifestations, including black, loosened stools, increased intestinal activity, cramps and green tongue.

Humans are more susceptible to vanadium poisoning via inhalation. In some industrial processes where vanadium compounds are used, skin contacts also may be a problem. Chronic inhalation of vanadium at concentrations greater than $1000 \mu \mathrm{g} / \mathrm{m}^{3}$ results in adverse effects that become more severe with increasing exposure levels. Among industrial 
workers chronic vanadium intoxication has been characterized by such clinical signs as loss of appetite; both a dry and expectorant cough, blood stained sputum, infected pharynx, labored breathing, wheezing, rales, bronchospasm, nausea, inflamation of the eyelids, fatigue and depression. Specific respiratory ailments include pneumonia, bronchitis, bronchopneumonia and tuberculosis. Statistical studies suggest an association of vanadium air pollution with several respiratory diseases, heart diseases and cancers; a synergism between vanadium and sulfur dioxide in respiratory diseases; and an involvement of vanadium, arsenic and zinc in lung cancers. Biochemical analyses show that vanadium interfereswith enzymes systems and inhibits the synthesis of phospholids. Also, there are reports that vanadium reduces natural immunity to diseases in mammals.

The toxicity of vanadium has been discussed by Hopkins et al. [59]. Reports on vanadium toxicity along with occupational and environmental exposure to vanadium have been discussed by Venugopal and Luckey [74] and Sittig.

Zinc is an essential element in the diet of humans and animals. It has a diverse role in the normal biochemistry of mamalian systems. Zinc is found in every tissue, but the total body burden of zinc mainly is distributed in bone and muscle. An efficient homeostatic mechanism acts to regulate the absorption and excretion of zinc following the required intake of the element. However, the homeostatic mechanisms dysfunction at abnomally high levels of zinc intake. Hence, zinc 
intoxication is possible in humans and animals.

The absorption of dietary zinc mainly occurs in the samll intestine and to some extent in the large intestine. Many factors enter which enhance or interfere with the passage of zinc across the intestinal membranes. As concluded from experimental studies on rats and sheep, high dietary calcium decreases zinc absorption; but no evidence of this relationship was found in humans. The results of other experimental studies using human subjects suggest that individuals on protein deficient diets may have higher zinc absorption than those on normal protein diets. Following inhalation, dusts of zinc salts are briefly retained in the lungs before being absorbed from the cellular membranes and taken up by the blood.

The spread between beneficial levels and toxic levels of zinc evidently is wide. From the available but sparse information on zinc toxicity in humans and animals, normal dietary zinc intake is approximately $1 \%$ of the amount necessary to induce toxicosis. However, toxicosis may result when the intrusion of soluble zinc compounds by either ingestion or inhalation overburden the homeostatic excretory mechanism of the body. Among medical investigators there is agreement that zinc potentiates adverse clinical states by interfering with the utilization of other essential elements, such as calcium, copper, iron and magnesium. Documented reports reveal human adults can tolerate up to $600 \mathrm{mg}$ oral zinc sulfide per day which is equivalent to a daily intake of $165 \mathrm{mg} z$ inc. Patients given this amount of zinc sulfide as a therapeutic agent in healing leg ulcerations displayed no discernable signs of blood, liver or kidney disorders. On the other hand children 
may react adversely to medicinal zinc agents; lethargy in children has been observed following excessive oral intake of zinc supplements.

Evidence from the literature on the involvement of inhaled zinc compounds in chronic disorders is inconclusive. The National Research Council [94] cites two reports on occupational exposure to zinc; one which suggests that health may not be affected adversely by longterm exposure to zinc oxide fumes at concentrations ranging from $1-15 \mathrm{mg} / \mathrm{m}^{3}$; the other concludes that chronic exposure to zinc oxide fumes may lead to minor eqigastric disorders. Yet Venugopal and Luckey [74] state that the inhalation of $1-34 \mathrm{mg} / \mathrm{m}^{3}$ of zinc oxide causes metal fever and pneumonitis in humans. Also, the inhalation of zinc chloride produces pneumonities. Metal fever is an acute disability induced by the inhalation of metal fumes. Manifestations of metal fever include depression, nausea and headache.

Ruminants are less tolerant to high zinc ingestion than nonruminants. Cattle and lambs show symptoms of zinc intoxication at 1000 ppm zinc in feed while pigs are asymptomatic. Chronic zinc intoxication in animals is manifested by reduced weight gains from loss of appetite; reduced absorption of dietary copper and iron; and swelling of the joints followed by lameness due to increased zinc uptake by bone. Incidents of lameness and death in young horses foraging on grasses surrounding lead-zinc smelters have been reported in the literature. The concentrations of zinc in the grasses at one site ranged from 1100 to $3500 \mathrm{ppm}$. Zinc is toxic to fresh water fish. Zine impairs the gas exchange process at the gills and thereby deprives the tissues of oxygen. 
In experimental animals, zinc enhanced the growth of some malignant tumors caused by other carcinogens. Nevertheless, other studies of experimental animals and humans suggest that zinc suppresses certain types of malignant tumors. Knowledge of the mechanisms of zinc toxicity is limited. Since $z$ inc is considered an essential element, much of the literature on the properties of zinc has been related to zinc deficiency. The recently published document by the National Research Council summarizes the literature on zinc, including its toxicology. A review of the biologic properties of zinc and its compounds has been prepared at lesser length by Venugopal and Luckey [74]. 
Table BI

Concentrations of Selected Trace Eloments mich heve been found to have Toxic Effects in sowe ierrestriat Animis. Man, Biros and fish"

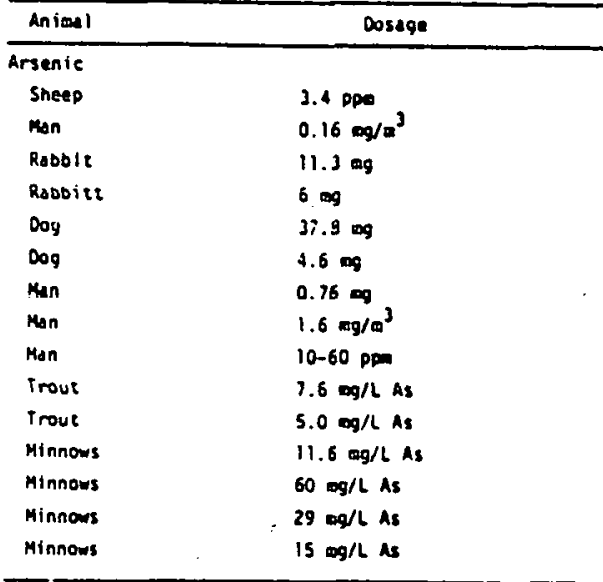

Form of exposure

IV - Intravenous adainistration

SC - Subcusaneous doninlstration

Effects

$0.2 \mathrm{gg} / \mathrm{a}^{3}$. inhalation, $4 \mathrm{hr}$. exposure

is og aisenic trioxice. oral

$\theta \mathrm{mg}$ ersenic trioslde. SC

$50 \mathrm{mg}$ orsente eriozice. oral

6 orsenic trtoxide. SC

$1,00 \mathrm{og}$ orsanic erionian. oral

$4 \mathrm{mg} / \mathrm{m}^{3}$ sodiue ersenate. inhalation. I $\mathrm{hr}$. exposure

Arsine

\begin{tabular}{|c|c|}
\hline Effects and coaments & Reference \\
\hline & ' \\
\hline Toxic & (1) \\
\hline no & {$[74]$} \\
\hline mo & $\cdot$ \\
\hline mo & $\therefore$ \\
\hline $60_{100}$ & $"$ \\
\hline $0_{100}$ & - \\
\hline 10 & - \\
\hline no & $"$ \\
\hline Dangerous for $1 / 2-1 \mathrm{hr}$. & [1] \\
\hline Tolerated. 30 days & $\cdot$ \\
\hline Tolerated, 24 nours & $\bullet$ \\
\hline Letna 1. 16 nours & • \\
\hline Lethal, 16 hours & - \\
\hline$C_{50} 48$ nown & " \\
\hline
\end{tabular}

LO $\mathrm{D}_{50}$ - the lethal cose to 50\%. of a population

LC 50 . the lethal concentration to $50 \%$ of a population

LO 50 : The lethal concentration to so. of a papu

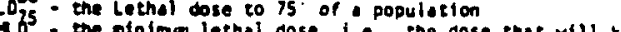

it least one anioul in the test population

Toxic- level at which toxic effects ore menifested

horomation on the behavior and toxtelties of these lements have been adjed.

\begin{tabular}{|c|c|c|c|c|}
\hline An Imal & Dosage & Form ind/or nethod of Eeposure & Effects and Conwents & Reference \\
\hline \multicolumn{5}{|l|}{ Enrium } \\
\hline Radoit & $27.6-52.1 \mathrm{ag} B \mathrm{a} / \mathrm{an}(\mathrm{an}) \mathrm{kg}$ & 40-75 be enloriceleninel kg. SC & to & [74] \\
\hline Rabolt & $170=9 / \mathrm{kg}$ & Ba Chloriae, oral & 10 & [1] \\
\hline Gat & $12.5-41.7 \Rightarrow$ Be/anteal kg & $18-60 \Rightarrow$ an chloride/onient kg. SC & to & [74] \\
\hline Dog & 6.9-13.8 og Balanted $\mathrm{kg}$ & $10-20 \Rightarrow$ chloride/untel kg. sc & Lo & “ \\
\hline Dog & $90 \sim 9 / k g$ & Ba enlorice. orsi & LD & [1] \\
\hline Pigeon & $500=9 / k g$ & So enloride, oral & 10 & $\cdot$ \\
\hline Morse & $800-1200 \mathrm{~kg} / \mathrm{kg}$ & Q4 Cnlortes, orel & 10 & $\cdot$ \\
\hline$\infty$ & $59.4 \mathrm{~kg} / \mathrm{antan} 1 \mathrm{~kg}$ & 909 ox chioridelentall to. ord. & $\mathrm{LD}_{100}$ & {$[34]$} \\
\hline Mn & $52.8 \mathrm{mg} / \mathrm{body} \mathrm{kg}$ & 80 ag chlorlde/body kg, oral & 200 & $\cdot$ \\
\hline Man & $56.2 \mathrm{~m} / \mathrm{boc} \mathrm{kg}$ & 100 ag as eartonate/body kg. oral & Ho & $"$ \\
\hline Guines otg & 274 mg/onfes: to & 350 ge flworlok/mienl kg. orel & 10,100 & $\cdot$ \\
\hline Rabbil & $127 \propto B$ Bantal to & 236 og. Ba aceutedantal kg, orol & Lo In I doy & $\cdot$ \\
\hline Rolotit & $438 \mathrm{mg} 8 \mathrm{animal} \mathrm{kg}$ & 815 og in cetcuce/ontasl kg, ors & Lo in I doy & $\cdot$ \\
\hline Rabole & $51.6 \Rightarrow 80 / \mathrm{anim} / \mathrm{kg}$ & $96=98$ scetute/onienl kg. SC & 10 & $\cdot$ \\
\hline \multicolumn{5}{|l|}{ seryllitu } \\
\hline $\operatorname{man}$ & $0.1 \mathrm{mg} / \mathrm{m}^{3}$ & 4 hour exposure. Inhelation & Tozic & {$[11]$} \\
\hline Pig & $2.5 \mathrm{me} / \mathrm{an}(\mathrm{me}) \mathrm{kg}$ & $7 \Rightarrow$ Be oxide/antini kq. se & no & $\cdot$ \\
\hline Rst & 9.8 m Be/aniesl kg & 06 ag Be chloridelanted ta. oral & $10_{50}$ & $\bullet$ \\
\hline Rat & $7.02 \mathrm{gog} / \mathrm{animal} \mathrm{g}$ & $82 \Rightarrow$ Be sulfatefonial tg. oral & $i^{\prime} o_{50}$ & $\because$ \\
\hline Rat & $0.15 \mathrm{mge/antanl} \mathrm{kg}$ & 1.809 be sulfate/anianl kg. Inhalation & $10_{50}^{30}$ & $\cdot$ \\
\hline Robolis & $0.15 \propto$ an/antaul by & $1.5 \mathrm{mg}$ an sulfote/antoul kg. sC & $\mathrm{LO}_{\text {so }}$ & - \\
\hline Rabble & 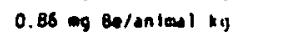 & $10 \mathrm{mg}$ ge prosonate/aniasl kg. Innolation & no & - \\
\hline
\end{tabular}


Taole oi (continued)

\begin{tabular}{|c|c|c|c|c|}
\hline $\ln |a|$ & Dosage & Form end/or Method of Exposure & Ef rects and Caments & rence \\
\hline \multicolumn{5}{|l|}{ Boruni } \\
\hline Don & 1 g/kg & soric detd, oral & $10^{5 N}$ & {$[1]$} \\
\hline Reobit & $4 / \mathrm{kg}$ & Boric ecid, oral & $10^{30}$ & $\therefore$ \\
\hline Rat & $5.14 \mathrm{~g} / \mathrm{kg}$ & Boric acio. oral & $\mathrm{LO}_{\mathrm{SO}}$ & 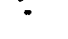 \\
\hline man (infants) & +5 & Boric acid, ingestion & Death & $\cdot$ \\
\hline Mn (swits) & $5-209$ & Boric ecid. Ingestion & Dosth & $\cdot$ \\
\hline Mouse & $2-39 / 49$ & Boras (Ma borate); oral & $\mathrm{LO}_{50}$ & - \\
\hline Man lillifldruili & $5-109$ & Borsx (the oorate). Ingestion & Deden & \\
\hline \multicolumn{5}{|l|}{ consing. } \\
\hline man. Inteals & $15 \mathrm{opm}$ & In food & In jurious & {$[1]$} \\
\hline Jepenese que. I & $.75 \mathrm{eg} / \mathrm{kg}$ of diet & Cadnius enloride & Testicular nypoplesio & - \\
\hline Jepanese quall & $s=g \mathrm{Co} / \mathrm{kg}$, body wt. & Cucaica chloride in diet & Depressed nemoglobin & “ \\
\hline Rasolt & $160 \mathrm{ppm}$ & Cacolice enloride in comerelal chom & Retarded gromen, anewid & * \\
\hline ait & $0.1-10$ pp & red mersl far 1 mir & Increated conc. In liver I hidnay & $=$ \\
\hline kat & $3-15000$ & Cs secul. single cose & Lethai & $\cdot$ \\
\hline Rat & 5 นต & $\ln \mathrm{F}_{2} \mathrm{O}$ & Decreateded life ipon & - \\
\hline Mn & 67 ope & Cd metil in drink. single dose & Slciness in childaren & $\dot{-}$ \\
\hline Mon & $0.1 \times C d / \mathrm{m}^{3}$ & Co oxide inhalation, chranic exposure & Hazardous with reference tu enphyseme & $(7)$ \\
\hline man & $43.5 \Leftrightarrow \mathrm{Cd} / \mathrm{a}^{3}$ & 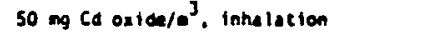 & Toxte & [74] \\
\hline$\infty$ & $56.6 \mathrm{mg}$ Coronieal kg & los 9 co sulfate/enianl kg. oral & 10,100 & $\cdot$ \\
\hline$\infty$ & $14.6 \% \mathrm{Cd} / \mathrm{an} / \mathrm{l}=1 \mathrm{~kg}$ & 27 mg Cd sulfare/anieul kg. SC & 10 & - \\
\hline Rabote & 43-92 eq CA/Animal *9 & 70-150 $\propto$ Cd sulfote/anfel kg. oral & 10 & $\cdot$ \\
\hline Rabst & $15.3-30.6 \circ \mathrm{Co} / \mathrm{anima} \mathrm{kg}$ & $29.50 \mathrm{mg}$ Co sulfate/anieal kg, SC & 10 & 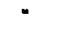 \\
\hline
\end{tabular}

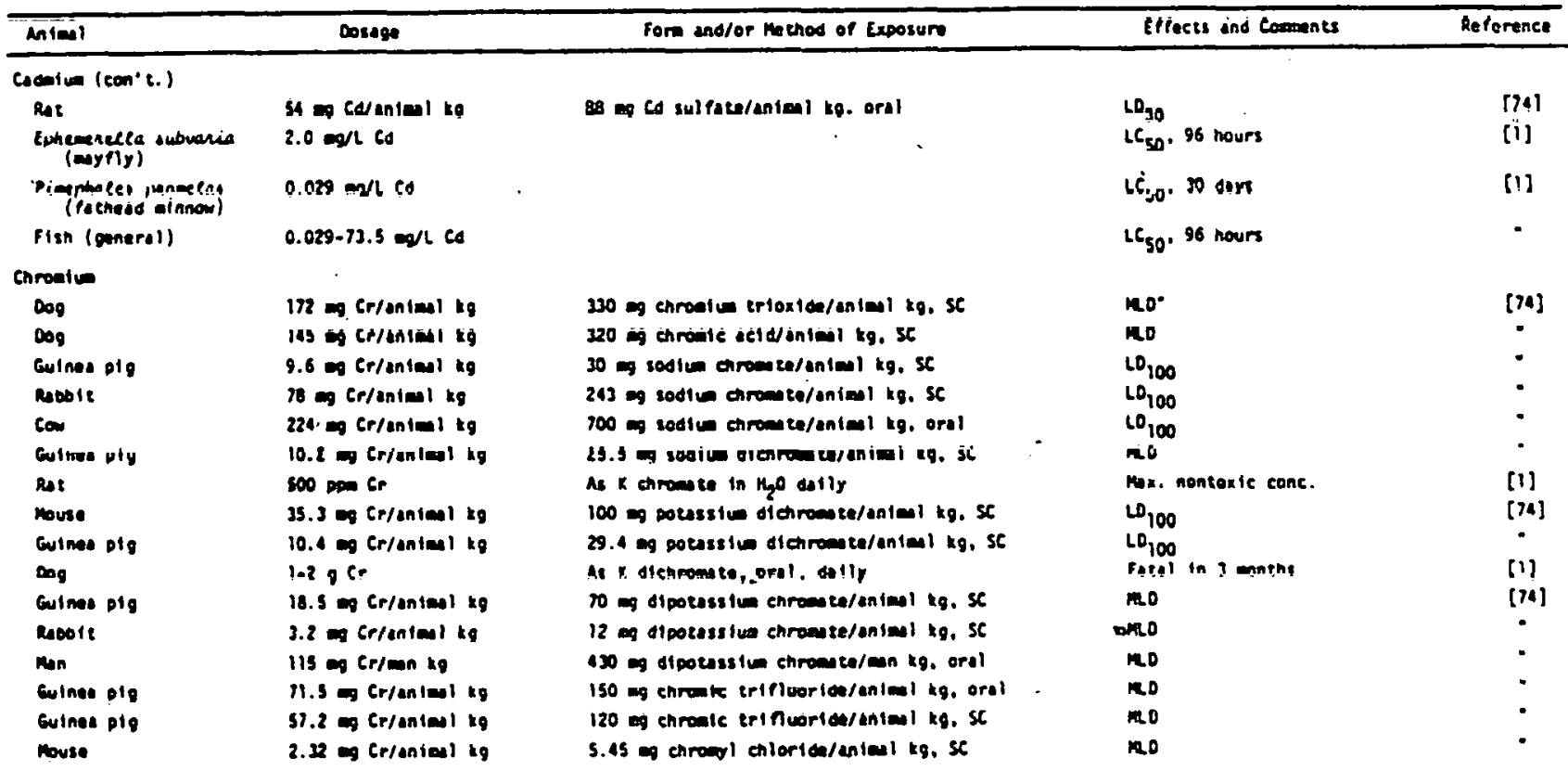


Table Bl (Continued)

\begin{tabular}{|c|c|c|c|c|}
\hline Aníasl & Dosage & Fora end/or method of Exposure & Effects and Comments & Reference \\
\hline \multicolumn{5}{|l|}{ Chromium } \\
\hline Guines ofg & $12.35 \mathrm{mg}$ Crisanime & 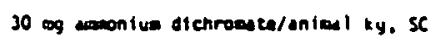 & $10_{100}$ & [74] \\
\hline Rat. muse & $18 \mathrm{cr}$ & As in chroance in feed dofily & Max. nontoxic eanc. & [1] \\
\hline Ra inbou trout & $10 \mathrm{cg} / \mathrm{c} \mathrm{Cr}$ & Exposed to mexuralent Cr for 15 coys & $\begin{array}{l}\text { Decreased sctivity and inou } \\
\text { inteke for } 25 \text { : of exposed } \\
\text { population }\end{array}$ & [.5] \\
\hline rothead minnom & $64.7 \mathrm{mg} / \mathrm{LCr}$ & & $L C_{5 u} \cdot 26$ hours $\mathrm{Cr}^{\mathrm{j} \cdot}$ & [1] \\
\hline Fothead ninitiow & $2.0 \mathrm{mg} / \mathrm{L} \mathrm{Cr}$ & י & Reprouctive inodiment. If moriths & $\cdot$ \\
\hline Broot eroue & $0.40 \mathrm{mog} / \mathrm{h} \mathrm{Cr}$ & & Regroductive imosiment, : yeors & $\cdot$ \\
\hline Brook trout & $50.0 \mathrm{mg} / \mathrm{l} \mathrm{Cr}$ & & $i_{m} .96$ nours & - \\
\hline Rainbow trout & $0.40 \mathrm{mg} / \mathrm{l} \mathrm{cr}$ & & Reproductive irsolment, 2 yeors & - \\
\hline Rainoow stroue & $69.0 \mathrm{mg} / \mathrm{L} \mathrm{Gr}$ & & $\mathrm{Tl}_{\mathrm{w}} \cdot 96$ hours & " \\
\hline Largemouth bass & $195 \mathrm{mg} / \mathrm{L} \mathrm{Cr}$ & & $\pi t_{n}, 48$ hours & • \\
\hline Largemuth bass & $94 \mathrm{mg} / \mathrm{l} \mathrm{rr}$ & & $\mathrm{TL}_{\mathrm{w}}, \mathrm{BO}$. hours & - \\
\hline \multicolumn{5}{|l|}{ Cooatt } \\
\hline Coctle & $>0.9 \mathrm{mg} / \mathrm{kg}$ & & Tnzic & [1] \\
\hline oog & $30 \mathrm{mg} / \mathrm{kg}$ & & Lecnal & $\cdot$ \\
\hline Rot & $500 \mathrm{ag} / \mathrm{kg}$ & & Letnal in $3-5$ weeks & $\cdot$ \\
\hline Rat & $1337 \mathrm{co}$ Co/onianl kg & $1700 \propto$ cobel tous oxide/enim $1 \mathrm{~kg}$, ord & $\mathrm{LO}_{50}$ & [34] \\
\hline Mouse & $36.3 \circ$ Co/eniml kg & $80 \mathrm{mg}$ cosols inloriatantael kg. orol & $100_{50}^{20}$ & 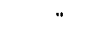 \\
\hline Mouse & $24.7 \mathrm{mg}$ Co/animal kg & 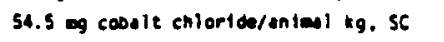 & MQO & - \\
\hline Rat & $81.7 \mathrm{~m} \mathrm{Ca/animl} \mathrm{kg}$ & 180 dy cosols chlortase/anianl kg. ord & $\mathrm{CO}_{50}$ & " \\
\hline Rat & $30 \mathrm{mg}$ Co/anians $\mathrm{kg}$ & of ag coosle chlortoe/ontanl kg. SC & $L 0_{100}$ & $\cdot$ \\
\hline Raboit & $49.5 \mathrm{mg}$ Co/snimel kg & 109 m cobalt enloriotentanieal kg. SC & MLO & - \\
\hline
\end{tabular}

\begin{tabular}{|c|c|c|c|c|}
\hline Anteal & Dosege & Form and/or hechod of Exposure & Effects and Comments & Reference \\
\hline \multicolumn{5}{|l|}{ cosole (con't.) } \\
\hline Sheep & $\rightarrow 3 \mathrm{~m} / \mathrm{kg}$ & $\cos _{2}$ in diet & Depressed appetite & [1] \\
\hline Men & & $500^{2} \mathrm{mg}$ cosolt eslortea/en kg, orul & Serlous toxic menlfestations & {$[i d j$} \\
\hline ene & 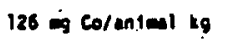 & $500 \mathrm{~m}$ toos lt Dwortorate/animol kg. oral & no & $\cdot$ \\
\hline Reoole & $00.5 \mathrm{~m} \mathrm{Co/ental}$ ig & 250 m cobelt nitrate/enteol kg. orel & mo & - \\
\hline Rabile & 24.1 og Co/animel kg & is ug cobalt nitraus/anteal kg. SC & $\mathrm{LO}_{\mathrm{sO}}$ & - \\
\hline \multicolumn{5}{|l|}{ Copper } \\
\hline snoep & $>20-30000$ & In foed or forspe & Toxle & [1] \\
\hline Rat & 417 a Cu/antal ko & $470 \mathrm{mg}$ cwrous oxide/antall $\mathrm{kg}$, oral & $\mathrm{lo}_{50}$ & [74] \\
\hline Rat & 567 cu/anienl kg & 710 a cuprle oxiogianimi kg. orsi & $10_{50}^{20}$ & $\because$ \\
\hline Ras & 66.1 Cwontanl kg & 100 as eupric chlorida/matesl kg, oral & $10_{50}^{50}$ & - \\
\hline Rat & 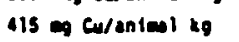 & $700 \mathrm{mg}$ oxychlorico/anteol kg. orel & $10_{50}^{30}$ & - \\
\hline Rat & $81.7 \propto$ Cwentad to & isg an eupric carsonetesenteol kq, oral & $\mathrm{LO}_{30}$ & $\cdot$ \\
\hline $\operatorname{son}$ & $216 \leadsto \mathrm{Cw}$ anieml kg & 420 g cuprte earoonate/antalal kg, oral & $10_{100}^{20}$ & • \\
\hline Ret & 207 Cwantent kg & $960 \mathrm{mg}$ eupric nitroca/unteal kg. orol & $10_{50}$ & $\cdot$ \\
\hline Ret & 120 Cowantenl kg & 300 m cupric sulfata/animl kg. orsl & no & $\cdot$ \\
\hline Rabbit & $20 \Rightarrow \mathrm{Cu} / \mathrm{entan} \mathrm{kg}$ & $50 \mathrm{ng}$ cwortc sulfate/enterel kq, oral & $\mathrm{no}_{100}$ & $\cdot$ \\
\hline Rat & $24 \times$ Cu/anieal kg & $960 \mathrm{mg}$ hydrous cupric eulfoce/animel kg. oral & 1050 & $\cdot$ \\
\hline Oxen . & So willy & Copper sulfate in diet & Fotal & [1] \\
\hline Setctleosek & $0.02 \mathrm{pos}$ cu & Cu( $\left(\mathrm{NO}_{3}\right)_{2}$. concentraction in wear & Lawest cone., wath in 192 hours & [96] \\
\hline Raineow trout & 0,08 ppo cy & $\mathrm{Cu}\left(\mathrm{NO}_{3}\right)_{2}$, concentration in weter & Lawst Conc., oesen in 20 nown & $\cdot$ \\
\hline Rainbor trowt & $0.037 \mathrm{~m} / \mathrm{h} \mathrm{Cu}$ & & Reduced egg and iry survival & [1] \\
\hline Stoelineod & $0.03 \mathrm{mg} / \mathrm{cu}$ & & Fry mortalley, 96 nours & - \\
\hline
\end{tabular}


Table bi (centiound)

\begin{tabular}{|c|c|c|c|c|}
\hline Animal & Dosage & Form snd/or thenod of Exposure & Effects and Coments & teference \\
\hline \multicolumn{5}{|l|}{ Copper (con't.) } \\
\hline Lake trout & $0.111 \mathrm{egh} \mathrm{Cu}$ & & Reducad ogs and ing survivel & $\{1\}$ \\
\hline Brown trowt & $0.031 \omega \mathrm{cos}$ & & Recucas $\bullet 99$ and fry survival & $\cdot$ \\
\hline $\begin{array}{l}\text { Sockeye and pink } \\
\text { Silnow }\end{array}$ & $0.025 \mathrm{ag} / \mathrm{Cu}$ & - & Morcaltity, reurowd develapant & $\cdot$ \\
\hline \multicolumn{5}{|l|}{ Fluarine } \\
\hline sllkwore lorves & $15 \mathrm{ppen}$ & Maf or $x F$ in folliag consunand & Lechel & [1] \\
\hline Frogs & 900 ppo & Imersion for 1 week in F-contuatndted wter & Lecher $=\left(L C_{\text {so }}\right)$ & $\cdot$ \\
\hline Frogs: & $3-300$ ppen & Kepe in F-contevinated weter for prolonged pertos & $\begin{array}{l}\text { Decrease in red and hite blood } \\
\text { cell counts }\end{array}$ & $\cdot$ \\
\hline Frog tudooles & 0.5 and $4.5 \mathrm{pgm}$ & In f-contawinated water & $\begin{array}{l}\text { Menepronosis celeved, conornel } \\
\text { thyrotid }\end{array}$ & $\bullet$ \\
\hline $\begin{array}{l}\text { Oenr } \\
\text { Livestock }\end{array}$ & $\begin{array}{l}1500 \text { ope found in bon } \\
\leq 50 \text { ppes }\end{array}$ & $\begin{array}{l}\text { Fros vegetation end ale in F-concaninated orea } \\
\text { In forage }\end{array}$ & $\begin{array}{l}\text { Fluoresis } \\
\text { Pasie. }\end{array}$ & $\cdot$ \\
\hline Cattie & $.40 \mathrm{ag} / \mathrm{kg}$ & In diet or $\mathrm{H}_{2} \mathrm{O}$ & Decreased allk oroduction, lanemess & - \\
\hline $\operatorname{men}$ & 25nn-smm agder & single tese" & Leterel & - \\
\hline Hin & $20-80 \mathrm{~g} / \mathrm{dag}$ & & In $10-20$ yrs.. cripoiling fluonos is & - \\
\hline \multicolumn{5}{|c|}{ ( } \\
\hline Tonds & 816 poe & alven in eorthivorms & 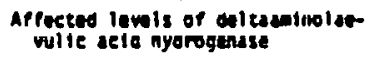 & [1] \\
\hline Horses & do (dn $-t)$. & In grass & Toxic & $*$ \\
\hline Morses, cattle & $120-150$ & In diet & Toric & 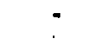 \\
\hline Cows & 67 equg/ay & lead in feed & Mining cumlative fatel dose & $\therefore$ \\
\hline
\end{tabular}

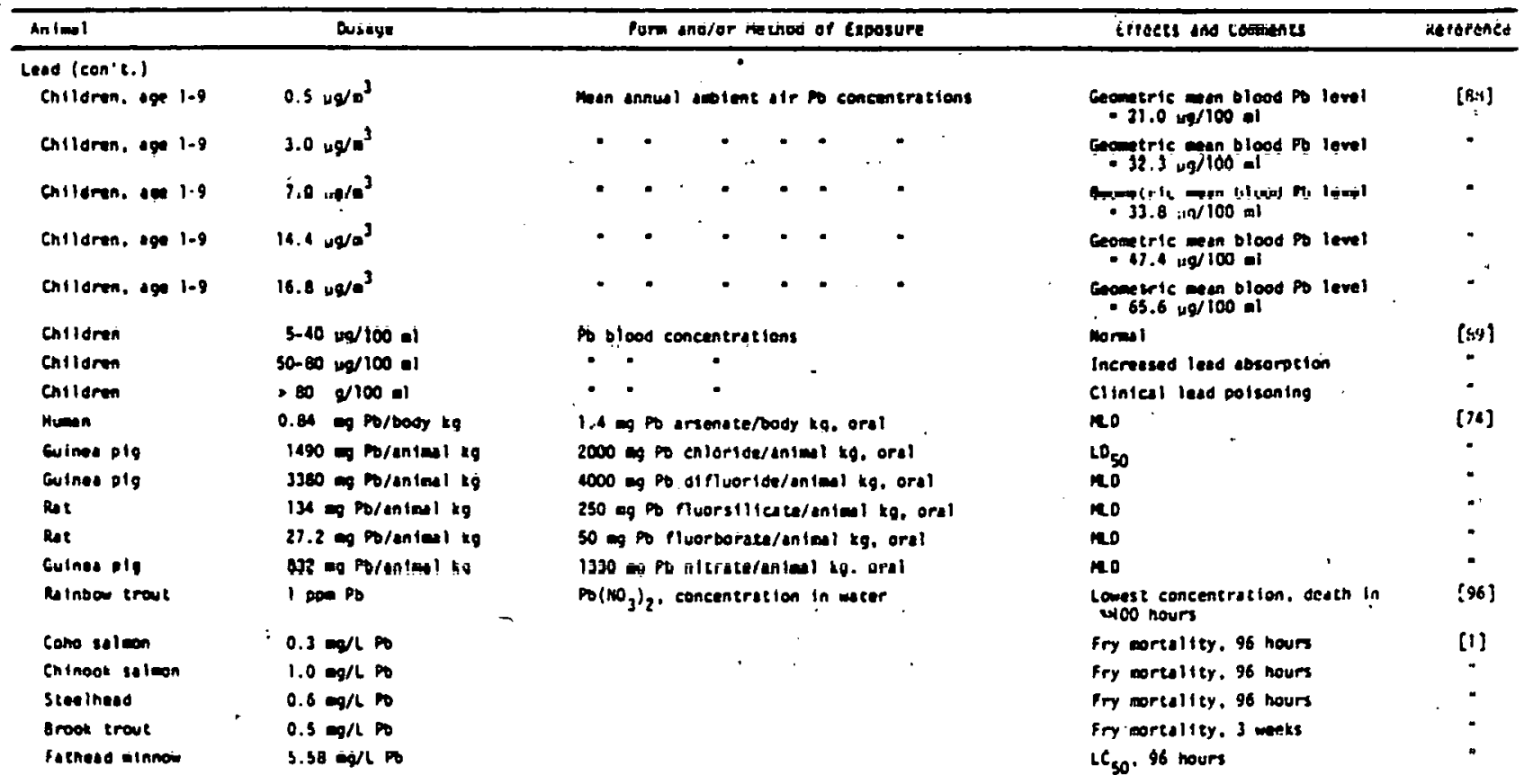


Table 81

\begin{tabular}{|c|c|c|c|c|}
\hline $\operatorname{An}(\mathrm{mal}$ & Dosage & form endior menod of Exposure & Effects and Comments & Reference \\
\hline \multicolumn{5}{|l|}{ Manganese } \\
\hline Ragoits & $10-20=9 \mathrm{~m}$ doloxide/ $\mathrm{u}^{3}$ & Intalation, 4 hrs/bay for J montens & $\begin{array}{l}\text { Fiorocte changes in lungs: } \\
\text { decreased nemogloo in ond } \\
\text { eryenrocyte levels }\end{array}$ & [4] \\
\hline Mouse & 316 ag $\mathrm{m} /$ onfiasl kg & 500 ag in doxice/anient kg. SC & 10,100 & $\cdot$ \\
\hline Guines plg & 50 og $\mathrm{m} / \mathrm{an} \operatorname{las} \mid \mathrm{kg}$ & $180 \mathrm{ag}$ hen enlortatantal kg. SC & $L_{100}$ & $\cdot$ \\
\hline Rabbit & $50 \mathrm{mg}$ m/animal kg & 180 og m enloride/anienl kg. SC & $10_{100}$ & “ \\
\hline Guined pig & $118 \mathrm{mg} \mathrm{m} / \mathrm{animal} \mathrm{kg}$ & $200 \mathrm{mg}$ in fluoride/anial kg. oral & MD & $\cdot$ \\
\hline \multicolumn{5}{|l|}{ Mercury } \\
\hline Preasane & $\begin{array}{l}\text { 3-13 pow fund in pheas- } \\
\text { ant liver tssuve }\end{array}$ & Mereury iroe environent & 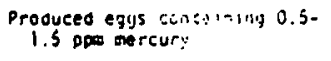 & [1] \\
\hline Pheasant eggs & $1.3-2$ ppo in eggs & Mercury from environaent & Decreased hatchabii: : r & $\cdot$ \\
\hline Red-called nawk & $\begin{array}{l}10 \text { ppro in livers of } \\
\text { chicks edtem }\end{array}$ & $\begin{array}{l}\text { Hawks fed chicks contenineted ol th } \\
\text { methylarcury }\end{array}$ & Lethal after one mon: & 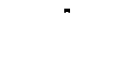 \\
\hline$\infty$ & $5=9 \mathrm{~kg} / \mathrm{s}^{3}$ & 4 hour exposure vis inhaletton & Mo & {$[7 \div]$} \\
\hline Rat & $16.1 \mathrm{~kg} \mathrm{Hg} / \mathrm{anfeul} \mathrm{kg}$ & $18 \Rightarrow$ mreurte axlda/animi kg, oral & $\mathrm{LO}_{50}$ & $"$ \\
\hline Rat & $178 \mathrm{Hg} / \mathrm{anias} \mathrm{kg}$ & $210 \mathrm{mg}$ mercurous enloridelentasl kg. orel & $10_{50}$ & " \\
\hline Wuse & $7.3 \oplus \mathrm{Hg} / \mathrm{an} \mid \mathrm{arl} \mathrm{lg}$ & 10 og nercurtc chloride/entasl kg. oral & $\mathrm{LO}_{50}$ & 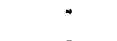 \\
\hline House & $11 \mathrm{mg} / \mathrm{an}(\mathrm{ms}) \mathrm{kg}$ & $23 \mathrm{mg}$ mereuric chloride/antesl kg. SC & $10_{50}$ & $\cdot$ \\
\hline Rabbit & $7.3 \mathrm{mg} / \mathrm{antal} / \mathrm{kg}$ & 10 eg eerartic enlorite/onienl kg. sc & $100_{100}$ & - \\
\hline Dog & 11.1 ag $\mathrm{kg} / \mathrm{antwo} 1 \mathrm{~kg}$ & is ng mercurtc chlorico/catest kg- arel & 10100 & 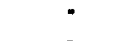 \\
\hline Mouse & $67 \mathrm{mg} / \mathrm{onimal} \mathrm{kg}$ & 110 a gercurous todide/ontall kg. oral & $\mathrm{LO}_{50}$ & " \\
\hline Muman & $157.6 \mathrm{mg} / \mathrm{body} \mathrm{kg}$ & $357 \mathrm{mg}$ mercuric lod de/body kg. orsl & no & $\cdot$ \\
\hline Rat & $227 \mathrm{mg} \mathrm{Hg} / \mathrm{sntanal} \mathrm{kg}$ & 297 ng dercurous nitrate/antall kg, oral & $20_{50}$ & $\cdot$ \\
\hline Mouse - & 2) Mg/onime $1 \mathrm{~kg}$ & 40 mg nercuric sulfate/anteal kg. orsl & $\cdot \mathrm{LO}_{50}$ & $\cdot$ \\
\hline Evines Dig & $16.5 \propto \mathrm{kg} / \mathrm{anims} 1 \mathrm{~kg}$ & 21 ag nethyl martic enloride, oral & $10_{50}$ & - \\
\hline
\end{tabular}

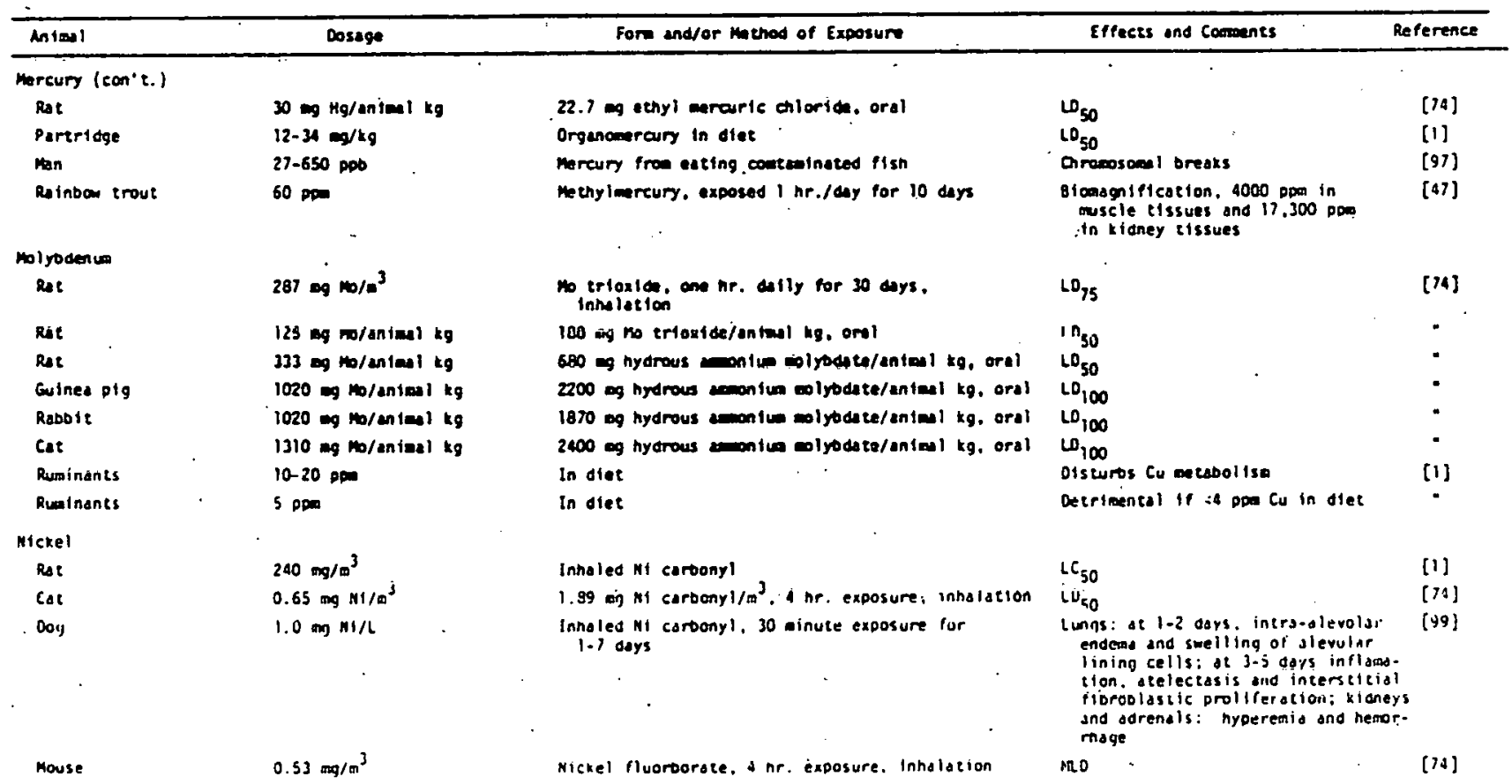


Table si (consinued)

\begin{tabular}{|c|c|c|c|c|}
\hline Animal & Dosage & form and/or meenos of Exposure & Effeces and Coments & ie lerence \\
\hline \multicolumn{5}{|l|}{ Miskel (con't.) } \\
\hline Gutnee pig & $5 \mathrm{gg}$ Mi/onianl kg & Spengy or colloldal & no & [74] \\
\hline Calves & $1000 \mathrm{ppon}$ & Nf cartonate in diet for 8 weaks & Decreesed growen & [1] \\
\hline Dog & $0.022-0.44$ & Ni chloride & $\mathrm{LO}_{50}$ & $\cdot$ \\
\hline Rot & $242 \propto 5 y / a n t a l k g$ & $1620 \mathrm{mg}$ nydrous Mt nitrate/ented kg. oral & $L D_{50}$ & [74] \\
\hline Guinea Dig. & $13.8 \mathrm{mg} / \mathrm{antan} / \mathrm{kg}$ & $62 \mathrm{gh}$ hydrous Ni sulfaze/anianl kg, SC & $10_{100}^{20}$ & $"$ \\
\hline Raboit & $112 \mathrm{~m} \mathrm{N1/animal} \mathrm{tg}$ & 500 erg hyorous Ni sulfate/onial $\mathrm{kg}$. SC & $L D_{100}$ & $\cdot$ \\
\hline$\infty 9^{\circ}$ & $112 \cdot$ N1/animil kg & 500 m hydrous $M 1$ sulfota/anianl kg. SC & $10_{100}$ & 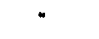 \\
\hline . Chicks & 100 ppos. & H1 Acelate and sulfate in diat & atcressed growth in 4 wh. old chicks & [1] \\
\hline Rat & $14.6 \mathrm{mg} \mathrm{M} / \mathrm{antan} / \mathrm{kg}$ & $50 \mathrm{mg}$ Wh inexaflworosilleace/antmal kg, oral & $\mathrm{LO}_{50}$ & {$[14]$} \\
\hline Fathedo minnows & $32 \mathrm{mg} / \mathrm{L}$ Ni & 96 nour exposure & $t C_{50}$ & [98] \\
\hline Aa inoow trout & $3209 / \mathrm{L} \mathrm{NI}$ & & $L C_{50}, 48$ nours & [1] \\
\hline $\begin{array}{l}\text { Stickleoack } \\
\text { Selenf uat }\end{array}$ & IpDom $\mathrm{Ni}$ & Hi(NOj), concentration in water & $\begin{array}{l}\text { Lowest concentration, Jeath in } \\
\text { ijo iwurs }\end{array}$ & $\{96\}$ \\
\hline \multicolumn{5}{|c|}{ Iso lwurn } \\
\hline Rats & 14 ugantasel kg & Inhdled elemental selenfun serosol & 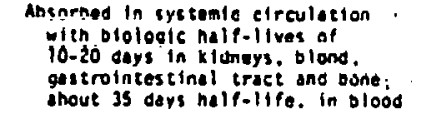 & $(100)$ \\
\hline Rats & 14 עg/बnim $1 \mathrm{~kg}$ & Inhaled solentous setd aenosol & (Same as above) & $\bullet$ \\
\hline Beegle $\infty$ ps & $80 \pm 17$ ug/onimul kq & Inhaled selentious ecid derosel & 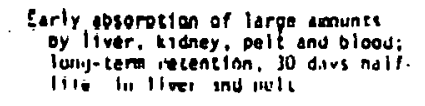 & $\{\ln 1\}$ \\
\hline Livestock & $24 \mathrm{mg} / \mathrm{kg}$ & Consund in regetation & Altoll disease & [1] \\
\hline It vestoek & $100.1000 \mathrm{my} / \mathrm{kg}$ & Consuned in regetation & Deoth & ${ } \cdot$ \\
\hline Gatsle & 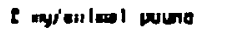 & & Lethal & - \\
\hline Sheep & 4659 & In selenste-bearing plants & Fatal in 20 hours & \\
\hline
\end{tabular}

\begin{tabular}{|c|c|c|c|c|}
\hline inimal & Dosege & Form and/or Method of Exposure & Effects and Coaments & Moference \\
\hline \multicolumn{5}{|l|}{ Seleniu= (con't.) } \\
\hline nog & 1,29 & sootun soiantes in foid & ress in 3 dayi & [1] \\
\hline ine & $15.3 \mathrm{~m} \mathrm{S/4n!ml} \mathrm{ho}$ & 25 aq enleniaus atidanienl bg. arol & .120 & [M] \\
\hline Rat & 2.8 Seranienl to & 4 se dloxide/onienl ta. sc & $60 \mathrm{gn}$ & $\cdot$ \\
\hline Acobir & $1.0 \mathrm{mog} / \mathrm{antas}$ t ka & $2.25 \mathrm{mg}$ solenten/antem $\mathrm{km}$, oral & $\mathrm{CO}_{50}$ & - \\
\hline$\infty$ & $1.8 \div$ soleniont ko & $4.0 \mathrm{mg}$ th selentea/animel kg. oral & $\mathrm{LO}_{50}$ & - \\
\hline Poul try" & $5=$ sing & Ory ration & Toule threshold & [1] \\
\hline Catel: & $1.4 \mathrm{mog}$ & In poden $r$ & Chronte polsoning & $\cdot$ \\
\hline 20001t & $2.9 \mathrm{mb}$ Ganleol th & $7.0 \mathrm{~m}$ Ha colematerantasl bol oral & Mo & [14] \\
\hline$\infty$ & 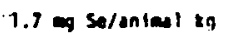 & $4.0 \mathrm{~m}$ ha selemote/aniasl ho, oral & no. & $\cdot$ \\
\hline fatnead Minnows (fry) & $2.9 \mathrm{mg} / \mathrm{L} \mathrm{se}$ & & $L C_{50} .96$ nours & [1] \\
\hline Bluagill jurentles & $40.0 \mathrm{~g} / \mathrm{L} \mathrm{Sa}$ & & $L C_{50} .96$ nours & $\cdot$ \\
\hline \multicolumn{5}{|l|}{ Vanadive } \\
\hline Dog & $33 \div 4$ Ng Y/el & $\checkmark$ pentozida. In vitro & 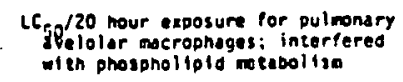 & [102] \\
\hline Robolt & $29+6$ ug $V /=1$ & $\checkmark$ pentoxice, in vitro & (sare as above) & $\cdot$ \\
\hline Rat & $39=8 t \omega \mathrm{b} b \mathrm{al}$ & $V$ pencostide Is ivitio & (Sagin is asove) & $\cdot$ \\
\hline Rat & $40=\mathrm{m} / \mathrm{m}^{3}$ & $70 \mathrm{ag}$ y pentoxlce/m $\mathrm{m}^{3}$. A hour exposure & $20_{100}$ & [74] \\
\hline $\operatorname{mon}$ & $60-120=9 v$ & Inroled & $\mathrm{LO}_{50}$ & [1] \\
\hline Ravols & $11.2 \mathrm{mg}$ V/animl $\mathrm{kg}$ & $20 \mathrm{ma}$ pentoxide/animel kg. SC & 20,00 & [74] \\
\hline Rat & 16 vanionl kg & 37 ag amonife metaranadate/antoul ke. SC & $10_{100}$ & $\cdot$ \\
\hline Rat & $69.6 \mathrm{mg}$ V/anial $1 \mathrm{~kg}$ & $160 \mathrm{~m}$ ancont le returenadace/animal kg. oral & $\mathrm{LO}_{50}$ & $\cdot$ \\
\hline Rabole & $6.53 \mathrm{mov}$ Voniml kg & 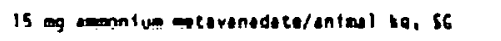 & 20 & $\cdot$ \\
\hline Reobit & $3.5 \mathrm{~g}$ V/animol kg & $20 \mathrm{~m} \vee$ trtbroalde/animal ka. Sc & 10,00 & * \\
\hline
\end{tabular}


Table 81 (coneinued)

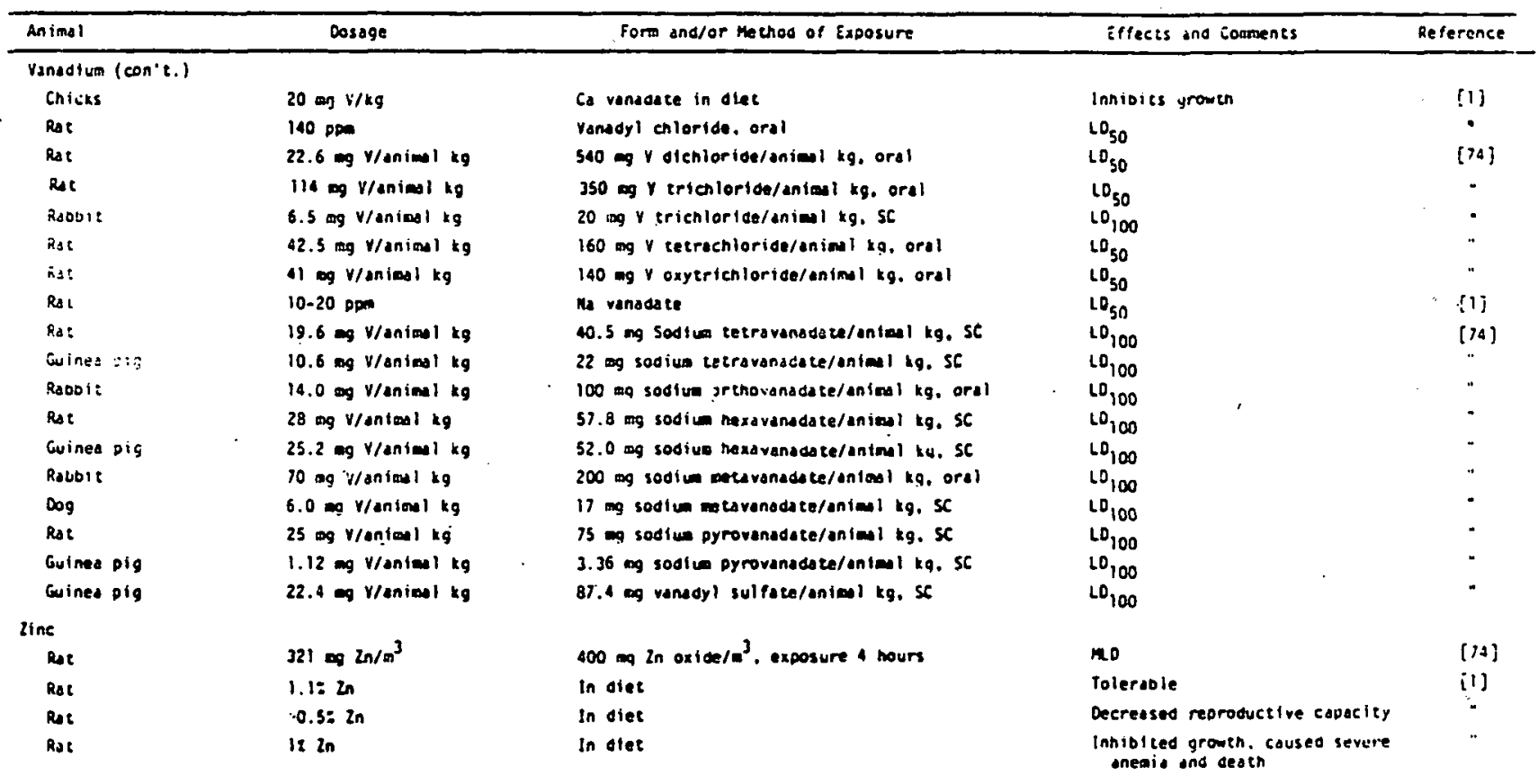

\begin{tabular}{|c|c|c|c|c|}
\hline Anial & Dosage & For and/or thed of Exposure & Etfocts and Comments & Reference \\
\hline \multicolumn{5}{|l|}{ Zine $\left(\operatorname{con}^{\prime} t.\right)$} \\
\hline Colf. late, oxen & s00-1000 m/k & 2n in diet & Depressed welght & [1] \\
\hline Rat & & In cartonațe in feed & Anewid and os teoporos is & $\cdot$ \\
\hline Rat & $168=g$ In/entasl kg & $350 \mathrm{mg}$ In chlorica/anteal kg. orel & $\mathrm{LO}_{\mathrm{SO}}$ & [74] \\
\hline Guinee D1g & $120 \mathrm{mg} \mathrm{ln} / \mathrm{oninal} \mathrm{kg}$ & 250 in chlortde/antal log. oral & $10_{50}$ & $\cdot$ \\
\hline Culnes pig & $126 \propto 2 n / a n i n a l k g$ & $200 \Leftrightarrow 2 n$ fluoride/animl $* g$, oral & no & $\because$ \\
\hline Rose & $500 \Rightarrow$ In/enten $\mathrm{kg}$ & $2200 \mathrm{mg}$ In sulfatu/anieal kg. oral & 1000 & $\cdot$ \\
\hline Rat & $31.5 \mathrm{gg}$ in/anianl $\mathrm{kg}$ & 100 on In mexufnwrosflicate/entaol kg, oral & no. & $\cdot$ \\
\hline Reoplt & 477 an/on!es! ko & 2100 og in sulfuce/antmel ko. oral & $60_{100}$ & - \\
\hline Reobit & $B 4=\operatorname{In} / \operatorname{animel}$ tg & $370 \propto$ in sulfoceloniant kg, sc & 10,00 & $=$ \\
\hline Dog & $17.7 \oplus 2 n$ antalel kg & 78 m In sulfoke/anted kg. sc & 10,100 & $\cdot$ \\
\hline Yearling cono suleon & $4600 \mathrm{mg} / \mathrm{l}$ & 96 nours exposurn & $\mathrm{LC}_{50}$ & (103) \\
\hline Cono salien. & $0.14 \mathrm{mos}$ & & fry mortality, 96 nours & [1] \\
\hline Chinook selinon & $0.30=9 / 8$ & . & fry wortallty. 96, hours & $\cdot$ \\
\hline Steelnees & $0.30 \mathrm{mg} / \mathrm{L}$ & & fry mortaltty. 96 hours & - \\
\hline Ra inbour trout & $4.6 \mathrm{mo/h}$ & & $L C_{50} 5$ ders & $\cdot$ \\
\hline Ro inbor trout & 0.5 ope $2 n$ & 2nso, in weter & $\begin{array}{l}\text { Lowest concentration to eause } \\
\text { mortality in } 64 \text { nours }\end{array}$ & [96] \\
\hline Stfekleback & 0.3 oDa $2 n$ & $\mathrm{inSO}_{4}$, in weter & $\begin{array}{l}\text { Lamest concentraction to cause } \\
\text { o mortality in } 204 \text { hours }\end{array}$ & - \\
\hline
\end{tabular}


Notes and References for Chapter 4

[1] Dvorak, A. J., Lewis, B. G., et al., Impacts of Coal-Fired Power Plants on Fish, Wildlife and Their Habitats. Prepared for the Fish and Wildlife Service, U. S. Department of the Interior, Washington, D.C., FWS/OBS-78/29, March 1978.

[2] Munshower, F. F. and DePuit, E. J., "Terrestrial Ecosystem" in Energy Research and Development Association Report, The Potential Impact of Coal-Fired Power Plants in the Northern Great Plains, Annual Report. Ames Lab., Iowa State University, Ames Iowa, Activity RX-02-03, February 1978. pp. 34-52.

[3] Purves, David, Trace Element Contamination of the Environment. Elsevier Scientific Publishing Co., New York, 1977.

[4] Schubert, Jack, "Beryllium and Berylliosis," in Readings from Scientific American, Chemistry and the Environment, ed. by Carole L. Hamilton, W. H. Freeman and Co., San Francisco, 1973.

[5] D'Itri, Patricia and D'Itri, Frank M. Mercury Contamination: A Human Tragedy, John W. Wiley and Sons, New York, 1977.

[6] Goldwater, Leonard J. "Mercury in the Environment," in Readings from Scientific American, Chemistry and the Environment, ed. by Carole L. Hamilton, W. H. Freeman and Co., San Francisco, 1973. pp. 328-334.

[7] Leh, Francis K. V. and Lak, Richard K. C. Environment and Pollutions: Sources, Health Effects, Monitoring and Control. Charles C. Thomas Publisher, Springfield, Illinois, 1974.

[8] Southwest Energy Study. Summary Report: An Evaluation of CoalFired Electric Power Generation in the Southwest.. Prepared by the Study Management Team for the Federal Task Force, November 1972. pp. $9-16$.

[9] Coal Resources Work Group. Trace Element Content of the Soils and Vegetation in the Vicinity of the Soils and Vegetation in the Vicinity of the Four Corners Power Plant, Draft Statement of the Southwest Energy Study, Appendix J-III, February 1972.

[10] Kubota, J. et al., "Consequences of Soil Imbaiances," Geochemistry and the Environment: The Relation of Selected Trace Elements to Health and Disease, Vo7. II, U. S. National Committee for Geochemistry, National Academy of Science Publication, Washington, D.C. 1974.

[11] Nicholas, D. J. D., "The Function of Trace Elements in Plants," in D. J. D. Nicholas and A. Egan (eds.), Trace Elements in SoilPlant-Animal Systems, Academic Press, New York, 1975. pp. 181-198. 
[12] Broadman, N. K., "Trace Elements in Photosynthesis," in D. J. D. Nicholas and A. Egan (eds.), Trace Elements in Soil-Plant-Animal Systems, Academic Press, New York, 1975. pp. 199-212.

[13] Walsh, L. M., Erhardt, W. H. and Seibel, H. D., "Copper Toxicity in Snapbeans (Phaseolus vulgaris L.)", Journal Environmenta? Quality 1 (1972). Pp. 197-200.

[14] Keith, Larry H. and Telliard, William A., "Priority Pollutants: I-a Perspective View," Environmental Science and Technology, Vol. 13, No. 4 (April 1979). pp. 416-423.

[15] Four Corners Agriculture and Forestry Development Study, Forestry Resources in the Four Corners Economic Development Region, Special Report No. 5, New Mexico State Experimental Station, May 7971.

[16] Arizona Statistical Review, 34th-Annual Edition, Economic Research Department, Valley National Bank of Arizona, Phoenix, Arizona September 1978.

[17] Statistical Abstract of Utah, 1976, Bureau of Business and Economic Research, College of, Business, University of Utah.

[18] Liebig, G. F. Jr., "Arsenic," in Homer Chapman (ed.), Diagnostic Criteria for Plants and Soils, Department of Soils and Plant Nutrition, University of California Division of Agricultural Sciences, Riverside, 1966. pp. 13-23.

[19] Vanselow, Albert P., "Barium," in Homer Chapman (ed.), Diagnostic Criteria for Plants and Soils, Department of Soils and Plant Nutrition, University of California Division of Agricultural Sciences, Riverside, 1966:. pp. 24-32.

[20] Griffitts, W. R. et al., "Beryllium," in Geochemistry and the Environment: The Relation of Selected Trace Elements to Health and Disease, Vo?. II., U. S. National Committee for Geochemistry, National Academy of Science Publication, Washington, D.C. 1974. pp. $7-10$.

[21] Curtin, G. C., King, H. D. and Mosier, D. L., "Movements of Elements into the Atmosphere from Coniferous Trees in Subalpine Forests of Colorado and I daho," Journal of Geochemical Exploration, Vol. 3 No. 3 (JuTy 1974). p. 245-263.

[22] Bradford, G. R., "Boron," in Homer Chapman (ed.), Diagnostic Criteria for Plants and Soils, Department of Soils and Plant Nutrition, University of California Division of Agricultural Sciences, Riverside, 1966. pp 38-61. 
[23] Page, A. L., Bingham, F. T. and Nelson, C., "Cadmium Absorption and Growth of Various Plant Species as Influenced by Solution Concentration," Journal of Environmental Quality, Vol. 1, No. 3 (1972). pp. 288- 291.

[24] National Academy of Science, Chromium, Medical and Biological Effects of Environmental Pollutants, Committee on Biologic Effects of Atmospheric Pollutants, Division of Medical Sciences, National Research Council, 1974.

[25] Pratt, P. F., "Chromium," in H. D. Chapman (ed.), Diagnostic Criteria for Plants and Soils, Department of Soils and Plant Nutrition, University of California Division of Agricultural Sciences, Riverstde, 1966. pp. 136-141.

[26] Norrish, K., "Geochemistry and Mineralogy of Trace Elements," in D. J. D. Nicholas and A. Egan (eds.), Trace Elements in SoilsPlant-Animal Systems, Academic Press, Inc., New York, 1975. pp. 55-81.

[27] Vanselow, A. P., "Cobalt," in Homer Chapman (ed.), Diagnostic Criteria for Plants and Soils, Department of Soils and Plant Nutrition, University of California Division of Agricultural Sciences, Riverside, 1966. pp. 142-156.

[28] National Academy of Science, Copper: Medical and Biological Effects of Environmental Pollutants, Committee on Biological Effects of Atmospheric Pollutants, Division of Medical Sciences, National Research Council, 1977.

[29] Reuther, W. and Labanauskas, C. K., "Copper," in Homer Chapman (ed.), Diagnostic Criteria for Plants and Soils, Department of Soils and Plant Nutrition, University of California Division of Agricultural Science, Riverside, 1966. pp. 157-179.

[30] Fleisher, Michael, et al., "Fluorine," in Geochemistry and the Environment: The Relatinn of Selected Trace Elcments to llealth and Disease, Vol. I, U. S. National Comittee for Geochemistry, National Açademy of Science Publication, Washington, D.C., 1974.

[31] Gordon, C. C. Tourangeau, P. C., and Rice, P. M., "Potential for Gaseous Contamination from Energy Extraction Process in the Northern Great Plains," in ERDA Report, The Potential Impact of Coal-Fired Power Plants in the Northern Great Plains, Annual Report, Ames, Lab., Iowa State University, Ames, Iowa, Activity RX-02-03, February 1978.

[32] Brewer, R. F., "Fluorine," in Homer Chapman (ed.), Diagnostic Criteria for Plants and Soils, Department of Soils and Plant Nutrition, University of California Division of Agricultural Science, Riverside, 1966. pp. 180-196. 
[33] McCune, Delbert C. and Weinstein, Leonard, "Metabolic Effects of Atmospheric Fluorides on Plants," Environmental Pollution, Vol. 1, No. 3 (January 1971) pp. 169-174.

[34] Mitchell, R. L. and Reith, J. W. S., "The Lead Content of Pasture Herbage," Journal of Science Food Agriculture 17 (1966). pp. 437-440. [As cited in Ter Harr (1975)]. pp. 437-440.

[35] Rains, D. W., "Lead Accumulation by Wild Oats (Auena Fatua) in a Contaminated Area," Nature 233 (1971). pp 210-211

[36] Sandstead, Harold, et a1., "Cadmium, Zinc and Lead," in Geochemistry and.the Environment: The Relation of Selected Trace Elements to Health and Disease, Vol. I, U. S. National Committee for Geochemistry, National Academy of Science Publication, Washington, D.C., 1974. pp. 43-56.

[37] Harr, G. T., "Lead in the Environment - Origins, Pathways and Sinks," in T. B. Griffin and J. H. Knelson (guest ed.), Lead: Environmental Quality and Safety, Supplement Vol. II, Academic Press, New York, 1975.

[38] Grandjean, Phi]ippe, "Lead in Danes: Historical and Toxicological Studies," in T. B. Griffin and J. H. Knelson (guest ed.), Lead: Environmental Quality and Safety, Supplement yol. II, Academic Press, New York, 1975.

[39] Brewer, R. F., "Lead," in Homer Chapman (ed.), Diagnostic Criteria for Plants and Soils, Department of Soils and Plant Nutrition, University of California Division of Agricultural Science, Riverside 1966. pp. 213-224.

[40] Arvik, J. H. and Zimdahl, R. L., "Barriers to the Foliar Uptake of Lead," Journal of Environmental Quality, 3(1974). pp. 369-73.

[41] Rolfe, G. L., "Lead Uptake on Selected Tree Seedlings," Journal of Environmental Quality 2(7973). pp. 153-157.

[42] Matrone, Gennard et al., "Manganese," in Geochemistry and the Environment: The Relation of Selected Trace Elements to Health and Disease, Vol. II, U. S. National Committee for Geochemistry, National Academy' of Science Publication, Washington., D.C. 1974. pp. 29-39.

[43] Black, C. A., Soil-Plant Relationships, John Wiley and Sons, Inc., New York, 1968.

[44] Labanauskas, Charles K., "Manganese," in Homer (napman (ed.), Diagnostic Criteria for Plants and Soils, University of California Division of Agricultural Science, Riverside, 1966. pp. 264-285. 
[45] Rogers, R. D., "Methylation of Mercury in a Terrestrial Environment," U. S. Environmental Protection Agency, EPA-600/3-75-014, 1975.

[46] Schroeder, Harry A., Cadmium, Zinc and Mercury, American Petroleum Institute (Air Quality Monographs 70-16) Washington, 1971.

[47] D'Itri, F. M., The Environmental Mercury Problem, Chemical Rubber Company Press, Cleveland, Ohio, 1972.

[48] Nobbs, C. L., "Mercury Use and Social Choice," in Mercury and the Environment: Studies of Mercury Use, Emission, Biological Impact and Control, Organization for [conomic Co-operation and Devclopment Paris, France, 1974.

[49] Lonergan, J. F., "The Availability and Absorption of Trace Elements in Soil-Plant Systems and their Relation to Movement and Concentrations of Trace Elements in Plants," in D. J. D. Nicholas and A. Egan (eds.), Trace Elements in Soil-Plant-Animal Systems, Academic Press, Inc., New York, 1975.

[50] Johnson, Clarence, "Molybdenum," in Homer Chapman (ed.), Diagnostic Criteria for Plants and Soils, Department of Soils and Plant Nutrition, University of California Division of Agricultural Science, Riverside, 1966.

[51] Allaway, William $\mathrm{H}$. et al., "Interactions of Trace Elements," in Geochemistry and the Environment, Vol. II, The Relation of Selected Trace Elements to Health and Disease, Subcommittee on the Geochemical Environment in Relation to Health and Disease, U. S. National Committee for Geochemistry, National Academy of Science Publication, Washington, D.C. 1974. PP. 111-115.

[52] Davis, George K. et al., "Copper and Molybdenum," in Geochemistry and the Environment, Vol. I, the Relation of Selected Trace Elements to Health and Disease, Subcommittee on the Geochemical Environment in Relation to Health and Disease, U. S. National Committee for Geochemistry, National Academy of Science Publication, Wașhington, D. C. 1974. pp. 68-79.

[53] Nielsen, Forrest H., et al., "Nickel," in Geochemistry and the Environment, Vol: II, The Relation of Selected Trace Elements to Health and Disease, Subcomittee on the Geochemical Environment in Relation to Heal th and Disease, U. S. National Committee for Geochemistry, National Academy of Science Publication, Washington, D. C. 1974.

[54] Vanselow, Albert P., "Nickel," in Homer Chapmar, (ed.) Diagnostic Criteria for Plants and Soils, Department of Soils and Plant Nutrition, University of California Division of Agricultural Sciences, Riverside, 1966. 
[55] Nationàl Academy of Science, Nickel: Medical and Biological Effects of Environmental Pollutants, Committee on Biological Effects of Atmospheric Pollutants, Division of Medical Sciences, National Research Council, 1975.

[56] Ganje, Tony J., "Selenium," in Homer Chapman (ed.), Diagnostic Criteria for Plants and Soils, Department of Soils and Plant Nutrition, University of California Division of Agricultural Sciences, Riverside, 1966.

[57] National Academy of Science, Selenium: Medical and Biological Effects of Environmental Pollutants, Committee on Biological Effects of Atmospheric Pollutants, Division of Medical Sciences, National Research Council, 1976.

[58] 01dfield, James E. et al., "Selenium," in Geochemistry and the Environment, Vol. I, The Relation of Selected Trace Elements to Health and Disease, and U. S. National Committee for Geochemistry, National Academy of Science, Washington, D.C., 1974.

[59] Hopkins, Leon L. Jr., et al., "Vanadium," in Geochemistry and the Environment, Yol. II, The Relation of Selected Trace Elements to Health and Disease, Subcommittee on the Geochemical Environment in Relation to Heal th and Disease, U. S. National Committee for Geochemistry, National Academy of Science Publication, Washington, D. C. 1974.

[60] Pratt, Parker, "Vanadium," in Homer Chapman (ed.), Diagnostic Criteria for Plants and Soils, Department of Soils and Plant Nutrition, University of California Division of Agricultural Sciences, Riverside, 1966. pp. 480-483.

[61] Chapman, Homer, "Zinc," in Homer Chapman (ed.), Diagnostic Criteria for Plants and Soils, Department of Soils and Plant Nutrition, University of California Division of Agricultural Sciences, Riverside, 1966. pp. 484-499.

[62] Rosehart, R. G. and Lee, J. Y., "The Effect of Arsenic Trioxide on Growth of White Spruce Seedlings," Water, Air and Soil Pollution, $2(1973)$. pp. 439-443.

[63] Ormrod, D. P., "Cadmium and Nickel Effects on Growth and Ozone Sensitivity of Peas," Water, Air and Soil Pollution, 8(1977). pp. 263-277.

[64] Matt, John K., "Varietal Response to Lead by Lettuce," Water, Air and Soil Pollution, 8(.1977). pp. 133-144. 
[65] Luckey, T. D. and Venugopal, B., Metal Toxicity in Marmals: Vol. 1, Physiologic and Chemical Basis for Metal Toxicity, Plenum Press, New York, 1978.

[66] Schroeder, H. A., Air Monograph \#70-17: Manganese, Environmenta? Affairs, American Petroleum Institute, Washington, D.C., 1970.

[67] Zingaro, Ralph A., "How Certain Trace Elements Behave," Environmental Science and Technology, Vol. 13, No. 3, (March 1979). pp. 282-287.

[68] Luckey, T. D., "Hormology with Inorganic Compounds," in Heavy Metal Toxicity, Safety and Hormology by T. D. Luckey, B. Venugopal and D. Hutcheson (eds.), Academic Press, New York, 1975.

[69] Sawicki, Eugene, "Analys is of Atmospheric Pollutants of Possible Importance in Human Carcinogenesis," in T. Y. Toribara, J. R. Coleman, B. E. Dahneke and I. Feldman (eds.), Environmental Pol lutants, Detection and Measurement, Plenum Press, New York, 1978.

[70] Leach, R. M., Jr., "Metabolism and Function of Manganese," in A. S. Prasad (ed.), Trace Elements in Human Health: Vol. II, Essential and Toxic Elements, Academic Press, New York, 1976. pp. 235-247.

[71] Organization for Economic Cooperation and Development, Mercury and the Environment, Paris, 1974.

[72] Natusch, D. F. S., Wallace, J. R. and Evans, C. A., Jr., "Toxic Trace Elements: Preferential Concentration in Respirabie Particles," Science, 183: 202-204, (1974).

[73] Environmental Protection Agency, Mercury, Lead, Arsenic and Cadmium in Biolotic Tissue: The Need for Adequate Standard Reference Materials, by Werner F. Beckert. U. S. Environmental Protection Agency, Environmental Monițoring Series August 1978, National Technical Information, Springfield, Virginia, EPA-600/4-78-051.

[74] Venugopal, B. and Luckey, T. D., Metal Toxicity in Mamma 1s: Vol. II, Chemical Toxicity of Metals and Metalloids, Plenum Press, New York, 1978.

[75] Sittig, Marshall, Toxtc Metals, Pollution Control and Worker Protection, Noyes Data Corporation, Park Ridge, New Jersey, 1976.

[76] Smith, Roger, "Arsenic," in Douglas H. K. Lee (ed.), Metallic Contaminants and Human Health, Academic Press, New York, 1972.

[77] Friberg, Lars, et al., Cadmium in the Environment, Chemical Rubber Company Press, Cleveland, Ohio, 1974.

[78] Fox, M. R. Spivey, "Cadmium Metabolism - A Review of Aspects Pertinent to Evaluating Dietary Cadmium Intake by Man," in A. Prasad (ed.) Trace Elements in Human Health and Disease, Vol. II: Essential and Toxic Elements, Academic Press, New York, 1976. pp. 401-430. 
[79] Piscator, Magnus, "The Chronic Toxicity of Cadmium," in A. Prasad (ed.), True Elements in Human Heal th and Disease: Vol II, Essential and Toxic Elements, Academic Press, New York, 1976. pp. 431-441.

[80] Schroeder, H. A., Air Quality Monograph \#70-15: Chromium, Environmental Affairs, American Petroleum Institute, Washington, D.C., 1970.

[81] Venugopal, B. and Luckey, T. D., "Toxicology of Non-Radioactive Heavy Metals and Their Salts," in T. D. Luckey, B. Yenugopal and D. Hutcheson (eds.), Heavy Metal Toxicity, Safety and Hormology, Academic Press, New York, 1975. pp. 4-73.

[82] Smith, Ralph G., "Chromium," in D. H. K. Lee (ed.), Metallic Contaminants and Human Health, Academic Press, New York, 1972. pp. 139-144.

[83] Hill, C. H., "Mineral Interrelationships" in A. Prasad (ed.), Trace Elements in Human Disease: Vol. II, Essential and Toxic Elements, Academic Press, New York, 1976. pp. 282-283.

[84] Navia, J. M., Hunt, C. E., First, F. B. and Narkates, A. J., "Flouride Metabolism--Effect of Pre-eruptive or Post-eruptive Fluoride Administration on Rat Caries Susceptibility," in A. Prasad (ed.), Trace Element in Human Health and Diseases: Vol. II, Essential and Toxic Elements, Academic Press, New York, 1976.

[85] Chisolm, J. J., "Lead Poisoning," in Readings from Scientific American, Chemistry and the Environment, W. H. Freeman and Company, San Francisco, 1973.

[86] Smith, J. L., "Metabolism and Toxicity of Lead," in A. Prasad (ed.), Trace Element in Human Health and Diseases: Vol. II, Essential and Toxic Elements, Academic Press, New York, 1976.

[87] Goyer, R. and Chisolm, J. J., "Lead," in D. H. K. Lee (ed.), - Metaliic Contaminants and Human Heaith, Academic Press, New York, 1972.

[88] deWerk Neal, Anneke, "Alterations in Disease Rates," in Richard A. Wadden (ed.), Energy Utilization and Environmental Health, John Wiley and Sons, New York, 1978. pp. 31-46.

[89] Hallenbeck, W. H., Kojola, W. H. and Jansen, S. J., "Physiological Changes," in R. A. Wadden (ed)., Energy Utilization and Environmental Health, John Wiley and Sons, New York, 1978. pp. 57-69.

[90] Mittinen, Jorma K., "Absorption and Elimination of Dietary Mercury $\left(\mathrm{Hg}^{2+}\right)$ and Methyl Mercury" in Morton W. Miller and Thomas C. Clarkson (eds.). Mercury, Mercurials and Mercaptans, Charles C. Thomas Publisher, Springfield, Illinois, 1973. pp. 233-243. 
[91] Friberg L. and Vostal, J., Mercury in the Environment - An Epidemiological and Toxicological Appraisal, Chemical Rubber Company Press, Cleveland, Ohio, 1972.

[92] Goldwater, L. J. and Clarkson, Thomas W., "Mercury," in D. H. K. Lee (ed.), Metallic Contaminants and Human Health, Academic Press, New York, 1972. pp. 17-55.

[93] Schroeder, H. A., Air Quality Monograph \#70-14: Nickel, Environmental Affairs, American Petroleum Institute, Washington; D.C., 1970.

[94] National Research Council, Zinc prepared by the Subcomfttee on Zinc of the Committee on Medieal and Biologie Effects of Environmental Pollutants, University Press, Baltimore, Maryland, 1979.

[95] Strik, J.J.T.W.A.; de Iongh, H.H.; van Rijn, J.W.A.; van Alkemade, and Wuite, T.P.,. "Toxicity of Chromium (VI) in Fish, with Special Reference to Organoweights, Liver and Plasma Enzyme Activities, Blood Parameters and Histological Alterations," in J. H. Koeman and J.J.T.W.A. Strik (eds.) Sublethal Effects of Toxic Chemical on Aquatic Animals. Elsevier Publishing Company, New York. (as cited in Lorz et al 1978). pp. $31-42$.

[96] Walker, C., Environmental Pollution by Chemicals, Hutchinson Educational Ltd., London, 1971.

[97] Skerfving, S. Lindsten, J, and Hanson, K., "Chromsome Breakage in Humans Exposed to Methy] Mercury Through Fish Consumption," Archives Environmental Health, Vol 21:133-139 (1970).

[98] Lorz, Harold W., Williams, R. H. and Fustish, C. A., Effects of Several Metals on Smolting of Coho Salmon, U. S. Envi ronmenta Protection Agency Publication, EPA-600/3-78-090, September 1978, National Technical Information Service, Springfield, Virginia.

[99] Sunderman, F. W.; Range, C.L.; Sunderman, F. W., Jr.; Donnley. A. J.; and Lucyszn, G. W., "Nickcl Poisoning XII, Metabolic and Fathologic Changes in Acute Pneumonitis from Nickel Carbonyl," American Journal Clinical Pathology, 36:477-491, 1961 .

[100] Burkstaller, M. A. and Cuddihy, R. G., "Distribution and Retention of Inhaled Selenium Compounds in the Rat," in R. F. Henderson, J. H. Diel and B. S. Martinez (eds.), Annual Report of the Inhalation Toxicology Research Institute, December 1978, pp. 315-318. Lovelace Biomedical and Environmental Research Institute Inc., National Technical Information Service, Springfield, Virginia, LF-60,UC-48. 
[101] Weissman, S. H. and Cuddihy R. G., "Retention and Distribution of Inhaled Selenious Acid Aerosols by Beagle Dogs". in R. F. Henderson, J. H. Diel and B. S. Martinez (eds.), Annual Report of the Inhalation Toxicology Research Institute, December 1978, pp. 310-314. Lovelace Biomedical and Environmental Research Institute Inc., National Technical Information Service, Springfield, Virginia, LF-60, UC-48.

[102] Sheriden, C. J.,Pfleger, R. C. and McClellan, R. O. "Cytotoxicity of Vanadium Pentoxide on Pulmonary Alveolar Macrophages from Dog, Rabbit and Rat: Effect on Viability and Effect on Lipid Metabolism," in R. F. Henderson, J. H. Diel and B. S. Martinez (eds.), Annual Report of the Inhalation Toxicology Research Institute, December 1978, Lovelace Biomedical and Environmental Research Institute, Inc. National Technical Information Service, Springfield, Virginia, LF-60, UC-48.

[103] Lorz, H. W. and McPherson, B. P., Effects of Copper and Zinc on Smoltification of Coho Salmon. U: S. Environmental Protection Agency Publication, EPA-600/3-77-032, (1977), 69 pp. (As cited in Lorz et al (1978)). 


\section{Chapter 5}

Economic Measures of Damages

This chapter attempts to summarize the state of the art in techniques for valuing environmental effects of trace elements in economic terms. No damage calculations are presented here, although approximate measures could be calculated as icated in the concluding chapter for some toxic effects. Rather, this chapter focuses on developing a metrodology which could be employed in future analysis, appropriate for specific trace elements which are shown to be of real concern. Based on the concluding chapter of this volume, it might be worthwhile to attempt to develop damage estimates specifically for mercury emissions from stacks or for mercury and selenium contamination of water from disposed ash pond deposits.

Our discussion of the economic quantification of toxic effects of trace elements emissions is organized as follows: risks to heal th must be valued both in terms of mortality (death) and morbidity (illness.). The next section treats these health damages respectively, discussing both economic and ethical aspects of valuing human health risks in dollar terms. Of course, effects of trace element emissions have broader consequences in the ecosystem, implying potential economic losses to recreation, e.g., prohibition of fishing in contaminated lakes and streams, and raise larger questions of environmental preservation and option values as well. These latter issues are treated as well under the title "ecosystem effects," an area wherein damage measures are a bit uncertain. The concluding section discusses the translation of economic damage estimates into measures of 
the benefits of controlling or reducing trace element emissions. Benefits are the reduced damages associated with control. However, reduced damages must be summed up over time (chronic cumulative impacts over thirty years are not unreasonable); across different individuals and groups (e.g., environmentalists, Indians, Chicanos, Anglo miners, etc.) all with potentially conflicting values; and for what amounts to highly uncertain health effects and events which may lead to exposure. Thus, our discussion of the construction of a benefit. measure for trace element control focuses on the fundamental issues of discounting the future, aggregation of values and uncertainty.

\section{Valuing Human Health Effects}
a) Mortality - Valuing Safety

Our first measurement problem relates to valuing safety. Many environmental costs take the form of risks to human life. Benefits result from reducing damages from such risks or increasing public or private safety. But, how are such safety benefits to be estimated in dollar terms withou't raising ethically objectionable notions such as a dollar value for human life? Economists have approached this issue recently by scrupulously avoiding any notion of valuing a particular human life (Mishan, 1971). In fact, if a willingness to pay measure is used, the value of a particular life can be taken as, from economic theory, infinity, since to induce a particular rational individual to accept a risk of certain death would require infinite compensation (no value is large enough). However, individuals do, in fact, accept compensation for small risks of (uncertain) death. Examples abound. Driving to work entails a small risk presumably compensated as part of wages or salaries. Jobs which are riskier than others can usually be shown to be paid more, all other things equal. Thus, a TV antenna installer voluntarily 
risks falling from rooftops, but presumably demands a priori compensation for the additional risk he undertakes. Studies of wages and risk have shown that differing groups and individuals require between $\$ 340$ (Thaler and Rosen, 1976) to as much as $\$ 1000$ (Smith, 1974) more in annual income to voluntarily accept increased annual job related risks of death of about one in one thousand (.001). Of course, such estimates may include some a priori compensation for non-fatal accidents as well, including possible compensation for pain and suffering. However, if ex post compensation is available for non-fatal events, then wage differentials should only capture the value of risk of mortality. Economists then argue that if a project or program reduces risk of death to 1000 people by .001 that we would expect to save one life $(.001 \times 1000)$ and that the increased safety is worth between $\$ 340,000$ and $\$ 1$ million as a benefit $(\$ 340 \times 1000$ people or $\$ 1000 \times 1000$ people). Note, this is an a priori measure of the value of safety to 1000 people, of whom one is expected to die, not an ex post measure of how much should or would be paid to compensate for a particular death. However, difficulties remain. First, in observing actual expenditures for safety, enormous differences are apparent. Many traffic safety programs -- more barricades, traffic lights, etc..-- could save an expected life at a cost of less than $\$ 100,000$. Given the numbers above, it would seem that the public would clamor for better roads or at least buckle their own seatbelts more often than about $25 \%$ of the time. On the other hand, public airline safety may cost more than one million dollars per expected life saved, yet public pressure still exists for safer airine operations. It appears then, that the public rather readily accepts 
individuals killing themselves in their own automobiles, but views public airline safety in a very different way. Economists tend to make no distinction, but it may well be that a significant ethical difference exists between public and private safety, i.e., knowingly imposing a risk on oneself is "right," while imposing a risk on someone else is "wrong."

The economics of safety as discussed above has developed rapidly over the last several years. Unfortunately, earlier misguided attempts at measuring the value of safety programs have given economists a "black eye" for supposedly advocating that individual human lives could be valued as the lost economic productivity associated with a shortened life span. This view, pursued in great detail by Dorothy Rice (1966) and used by Laye and Seskin (1970) and others, implied that the value of the life of, for example, a 50 year old carpenter would be the remaining earnings to retirement age. The value of the life of a retired female (somebody's grandmother) was by the same argument taken to be zero. Similarly, small children, since many years would pass before they could hegin to earn productive income, were valued at next to zero, given the notion of discounting future earnings at a market rate of interest. Elaborate calculations were made for different individuals on the basis of age, occupation, sex, etc., to deter= mine the value of remaining earnings as a measure of the "value of life." On economic theoretical grounds all of these calculations have been shown to be nonsense. However, permanent harm remains in that many decisionmakers now shy away from any attempt to value the benefits of safety programs in dollar terms.

Now of course, in studying the problem of risk, economists utilize data on behavior where monetary compensation is actually paid for accepting 
risk, so an individual behavioral justification exists for the value measures used. We argue below in a brief discussion of ethics and risk that the economist is still utilizing a rather special situation to deriye estimates of the value of safety. But for the moment, let us follow through on the notion of a trade-off between safety and monetary compensation.

Imagine a game of Russian Roulette in which an individual is offered sums of money to participate voluntarily. If, for example, the risk of the gun firing when the trigger was pulled were only one in ten thousand, and the compensation for accepting the risk was $\$ 1000$, current economic studies would suggest that most people would accept the risk (this is a much better proposition -- risk versus compensation -- than driving to work for a typical day's pay!). However, economic theory, which assumes maximization of expected utility, predicts that as the probability of death increases, monetary compensation must increase dramatically. Figure 5.1 shows the expected kind of relationship between compensation and risk. As the probability of death approaches unity, compensation approaches infinity -- odds are that the participant won't survive the game to enjoy the proceeds, so, as pointed out before, no amount of money is sufficient. Note, however, that for small increases in annual risk of death such as those associated with risky jobs (typically less than .001 per year) annual job compensation is increased by $\$ 340-\$ 1000$, as shown in Figure 5.1 . Thus, economists now focus on the far left hand side of Figure 5.1 , only dealing with the dollar values necessary to compensate individuals for small voluntary risks. Total benefits for a safety program may, of course, sum up to a large dollar figure if many people obtain small reductions in risk through a public policy action. 
However, this method of valuing risk seems at least in part out of accord with observed human behavior. Just as the old value of life measure used by Rice and Lave and Seskin leads to counter intuitive results (e.g., grandmothers do not take up hang gliding because their lives:are "worthless" nor does society place a near zero value on the lives of children) the new measure of the value of safety seems to ignore the special importance many individuals place on involuntary or uncompensated risks. The risks associated with nuclear reactor accidents or nuclear waste storage, risks associated with public transportation including airlines, risks of flood, fires, earthquakes, or other disasters, all seem to be treated differently both in a social and individual perspective than do individual voluntary-compensated risks (for discussion on this point, see Starr, 1968). Economic theory, and consequently, empirical estimates of the value of safety have notabiy failed to account for these differences. Rather, economists have argued that placing a different value on safety in different situations is economically inefficient.

Figure 5.1

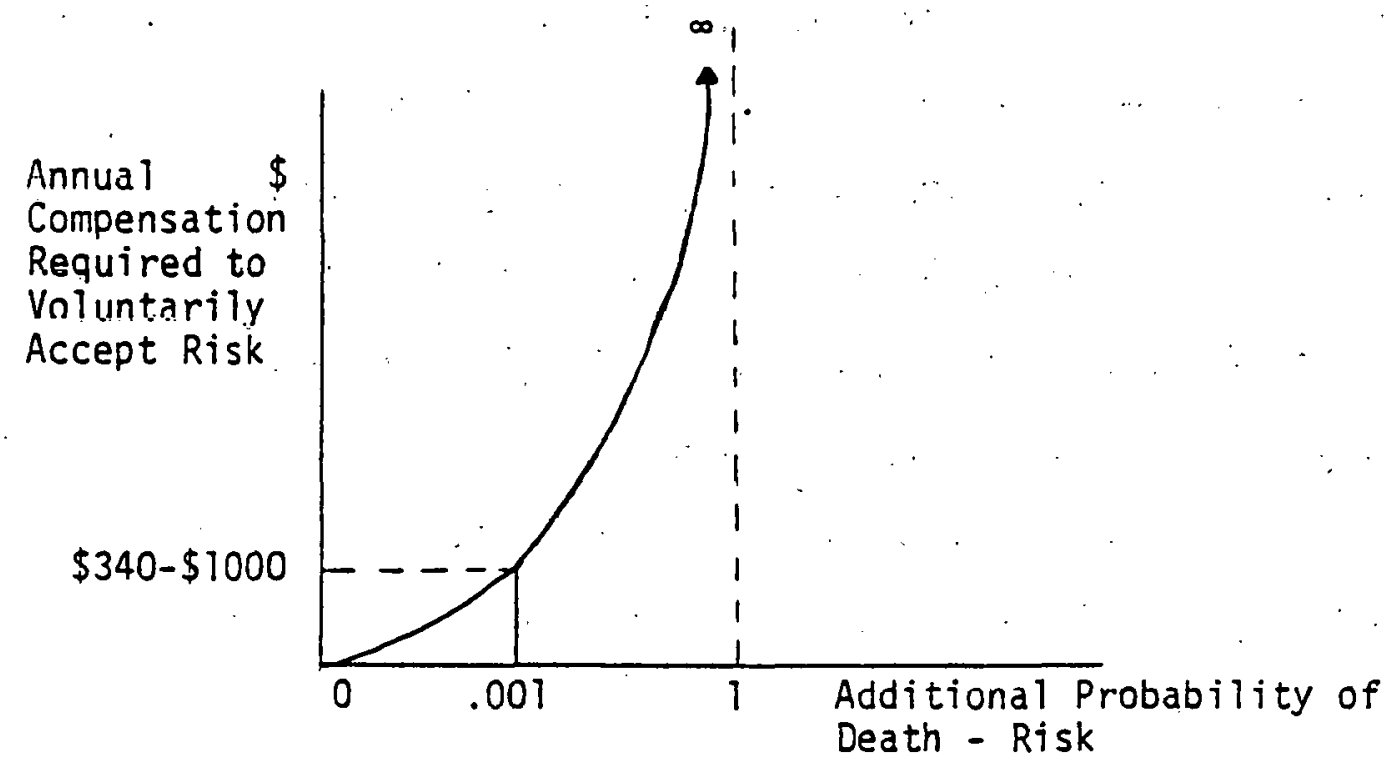


The logic behind this argument is as follows: given a fixed safety budget, if we have a program that can save one life for $\$ 50,000$ and another program which can save ten lives for $\$ 50,000$, we should pick the second program. Further, given a larger total budget, we would wish to pick the combination of programs which we would expect to save the greatest number of lives. We should pursue each of the programs to the extent that each additional life saved by a program costs the same at that margin.

The obvious counter to this argument is that individuals may well value safety differently in differing settings. Are uncompensated public health risks less ethically acceptable than compensated health risks? We address this question in the last part of this section.

b) Valuing Morbidity

The valuation of morbidity is conceptually even more difficult than mortality. Whereas, for mortality one can focus on a simplifying construct -- the a priori compensation required to induce individuals to accept risk of death -- morbidity has a number of diverse and difficult to quantify aspects. The easiest consequences of morbidity to quantify are lost economic productivity and increased medical care costs. Rice. (1966). and others have focused on these aspects in great detail in examining the "costs of illness." Based on this approach, it is conceptually possible to associate an increase in morbidity by disease with lost hours worked and with increased medical care costs. However, this approach will likely yield a misestimate of damages for a number of reasons. A more complete listing of the consequences of illness would include:

(1) earnings lost from time off work;

(2) increased medical care costs; 
(3) pain and suffering;

(4) lost work experience;

(5) lost work productivity from physical or mental impairment; and (6) increased leisure time.

The first two effects are included in the Rice estimates of the cost of. illness while the remaining effects are excluded. Information on values for pain and suffering, (3) above, are difficult to obtain. Whereas some consistent estimates of (1) and (2) have been used in, for example, court cases, settlements for pain and suffering vary enormously from case to case. Ideally, one would wish to obtain the willingness to pay of individuals to avoid pain and suffering. As we noted above, in the discussion on the value of safety, measures such as those developed by Thaler and Rosen (1976) are unlikely to be confounded with pain and suffering. A detailed estimate of an empirical model of risk-taking, accidents, etc., would likely be necessary to untangle pain and suffering from the other categories noted. Categories (4) and (5) are not so difficult to quantify, and their absence from the Rice estimates represents a major criticism of that work. Where we denote $E$ as annual earnings, $W$ as the hourly wage and $H$. as annual hours worked, we have the following identity:

$$
E \equiv W \cdot H
$$

and, consequently, (where $\Delta$ denotes change due to illness):

$$
\Delta E=W \cdot \Delta H+H \cdot \Delta W \text {. }
$$

In other words, the change in earnings due to illness $(\Delta E)$ is equal to the wage times the change (loss) in hours worked $(W \cdot \Delta H)$ plus the number of hours worked times any change (loss) in the wage rate due to illness $(H \cdot \Delta W)$. Rice has excluded this second phenomenon from her estimates of 
losses due to illness, and as a result, her estimates are likely to be severely downward biased. For example, Crocker-Schulze, et al. (1978) have found the effect of chronic illness in depressing wage rates to be statistically large. This depression in wage rates likely results from effects (4) and (5) listed above, i.e., from losses in work experience and seniority and from debilitating effects of illness on worker productivity. For example, to use an extreme case, an individual poisoned by mercury may become acutely $i l l$ and be unable to work for a period of time. These initial losses would be captured by (1) and (2) above. However, time lost from work will likely slow occupational advancement and the individual may suffer long term chronic mental and physical effects from mercury poisoning which would alter the type and intensity of future employment and consequently, wage level. These latter effects are captured in (4) and (5) above, and as Crocker-Schulze, et al. (1978) have demonstrated with data from the Michigan Household Survey, are quantifiable and possibly Targe.

Finally, illness may have benefits as well! A mild cold, while certainly in net undesirable, also provides opportunity for sympathy (the chicken soup syndrome) and for a "well earned" day in bed reading a good book. Further, chronic illness and disability may allow the individual opportunity for avoiding work longer than necessary (especially where disability insurance and other benefits may offset losses in real income). Thus, both acute and chronic illness may allow. for an increase in leisure time, a "benefit" which partly offsets costs of illness. Again, such "benefits" are likely to be very difficult to measure for obvious reasons. 
c) The Ethics of Valuing Health Effects

As we pointed out in discussing the valuation of risk to life, economists value health in what may be interpreted as a rather special set of circumstances. Ideally, we could view a perfect world in which a priori compensation takes place for all health risks. Health risks would be commodities traded in perfect markets. Thus, a new power plant locating in a previously pristine area would purchase the "right" to emit toxic trace elements from all.individuals potentially exposed. Such a market for risk would, of course, require perfect information on the part of all parties and some mechanism for overcoming common property problems of allocating airsheds and watersheds -- all of which explains why we do not often observe such markets in the real world. In any case, if such a market were in place, we could readily value health risks. Further, since all market transactions would be voluntary -- the power plant would have to pay enough to all affected parties to get them to voluntarily accept any associated health risks -- no real ethical issues would be raised. This conclusion holds because, in the extreme, an individual could demand infinite payment to accept the power plant, hence preventing its construction or location near that individaul. Note then, that this particular arrangement protects each individual's rights -- no one is forced to accept risk involuntarily -- analagous to the perfectly competitive private market case wherein, for example, a worker may voluntarily accept a higher wage to work at a riskier job, but is free not to accept the offered compensation and risk. (The assumption of competitive markets, of course, implies full employment with consequent free choice of occupation, i.e., no one is forced to take a risky job or starve. Our society, with actual unemployment, 
effectively prevents forced employment with welfare programs.) In the private risk case, however, if one individual in the wage market is very risk averse and does not wish to accept a risky job, then another less risk averse individual will likely take the position. Thus, tenth story windows are washed without raising ethical questions or creating a societa crisis oyer private risk. Alternatively, our power plant example points out an unfortunate problem with public as opposed to private risks. Construction of our example power plant might be blocked by one very risk averse individual objecting to the imposition of a public risk; that is, if the market we proposed for public health risk were in existence. The distinction between public (joint) risk and private (separable) risk is then an important one, because, if a private market existed for public risk, one risk averse individual could then block joint action.

Another example may be useful. Imagine that the passengers on an airliner are informed that by flying "low and fast" they will arrive at their next stop on time, making up for previous delays. ${ }^{\star}$ Clearly, a joint decision by the passengers is necessary. Those less risk averse will likely approve the divergence from standard procedures. Those fearful of flying in the first instance would likely resist. Airline risk is thus a public as opposed to private risk, since risks are joint -- indivisible -as opposed to separable.

Different ethical systems will view such a situation in very different ways. Democratic, Utilitarian [see Mill. (1963) and Bentham (1789)] or "Darwinian" [see Any Rand (1964)] ethics would all approve of "flying low

*This situation actually occured some years ago in Texas. Passengers voted for low and fast. 
and fast" if: (1) the majority voted for this alternative (Democratic), (2) the summed utility gain to those less risk averse exceeded the utility loss to those more risk averse (Utilitarian), or (3) the willingness to pay of those passengers wanting to fly low and fast exceeded the willingness to pay of those opting for "standard procedures" (Darwinian). The last of these criteria is identical with benefit-cost analysis, but all three are roughly consistent with benefit-cost analysis in that a very risk averse individual could be outvoted, out-"utilitied," or out-payed by other individuals. Thus these criteria in themselves .. including benefit-cost analysis .. do not protect individual rights against some concept of majority rule.

A number of ethical systems alternatively focus on individual rights. These include those proposed by Kant (1785), Rawls (1971) and the libertarian view as espoused recently by Nozick (1974). These ethical systems all would reject the imposition of uncompensated risk by the majority onto an objecting minority or individual. Each of these ethical systems might then reject benefit-cost analysis as it is traditionally performed. An alternative to traditional benefit-cost analysis, which weights benefits and costs in a manner consistent with a number of alternative ethical systems, has been proposed by Ben-David, Kneese and Schulze (1979). Application of these ideas would give decision-makers a number of al ternative outcomes in evaluating control of emissions of trace elements depending on the ethical system embodied in the analysis. Clearly, outcomes may be yastly different under ethical systems which look to the "good of the whole," as opposed to those which focus on protecting "individual rights." 
Valuing Ecosystem Effects

a) Recreation Damages

Although health damages can be quantified, as indicated above, use of these measures alone may, in fact, be inappropriate. For example, if a flash flood were to wash ash pond deposits into a watercourse, or if a lake were polluted by stack emissions so that mercury levels in fish rose to the point where human health effects were possible from consuming the fish, fishing would likely be prohibited. Thus, possibly, no heal th effects would occur. Economic damage from such events would then be the lost recreation value associated with a prohibition on fishing which would, hopefulity; be less than any damages caused by health effects which would occur without the prohibition. Of course, prevention of health damages would require appropriate monitoring, which is costly in and of itself. Thus, monitoring costs should be included in an alternative damage assessment based on recreation as opposed to human health costs. Actually, any monitoring system may fail to detect contamination some of the time, implying health effects will still occur with a reduced probability. Thus, uncertainty should be included in the analys is and heal th effects still have some probabalistic relevance. (See the concluding section of this chapter for a further discussion of uncertainty.)

The measurement of recreation damages depends on knowledge of the regional demand relationship for recreation. Two methodologies are available for determining recreation demand curves: (i) the Clawson-Hotelling travel cost approach, and (ii) the survey questionnaire approach. We will summarize each technique and indicate how it might be applied to estimating damages from trace element contamination of fish in streams and lakes, the 
most likely recreation. impact we have identified.

The Clawson-Hotelling methodology as described by Clawson and Knetsch (1966), Boyet and Tolley (1966), and Johnston and Pankey (1968), depends on knowledge of the relationship between rates of visitation to a particular site as a function of driving distance to the site. Presumabiy, individuals closest to a site, on average, will visit the site most frequently; the logic being that the effective price of visitation is the travel cost both in time and transportation of getting there. Thus, individuals or families closest to a site have the lowest price in travel costs, and will visit most frequently. As shown in the example demand curve in Figure 5.2,

\section{Figure 5.2}

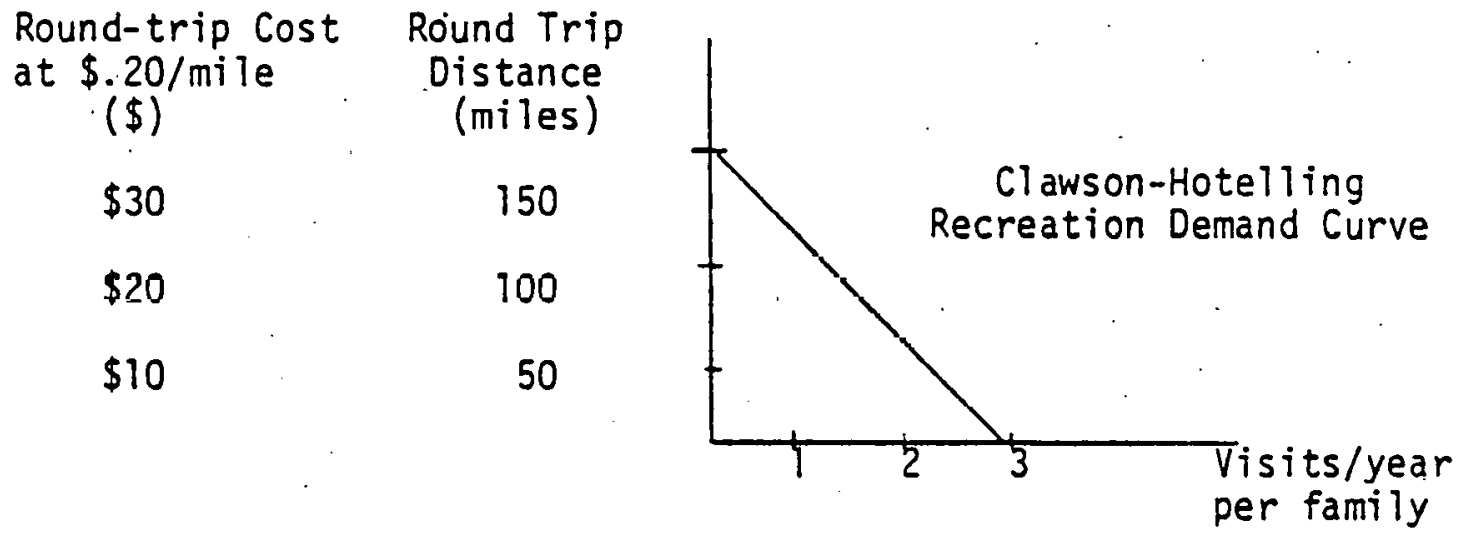

visits per year by family to a particular site typically decline with distance from "home" to the site. If one assumes a fixed cost per mile for transportation, one then has the demand curve by simply translating round trip distance into cost per-trip on the vertical axis, the assumption being that the price of a visit is the transportation cost. of the trip. This last assumption will likely lead to biased estimates of the true demand curve for a site for two reasons. First, demand will be overestimated 
if people enjoy the trip itself. For example, if a good lake for fishing is located in a scenic mountain area, the drive to the lake may include scenic vistas of value to fishermen. Thus, part of the travel costs are offset by the "benefits" of scenic vistas. As a result, the travel-cost based demand curve will overestimate the value of fishing alone. Second, other expenditures besides transportation costs such as food, lodging and recreation equipment (boats, fishing poles, bait, etc.) are also associated with the recreation experience and demand for these items would need to be included as well in approximating an overall willingness to pay measure for the benefits of fishing a particular lake or stream.

Discussions of techniques for calculating benefits (net willingness to pay) associated with outdoor recreation include Clawson (1959), Cesario (1970), Grubb (1968), and Knetsch (1963 and 1965). The basic result is that consumer surplus is the appropriate measure of benefits since all costs incurred by recreators on their own for travel must be subtracted from the total willingness to pay measure (area under the demand curve). Figure 5.3 demonstrates the technique for a particular household.

\section{Figure 5.3}

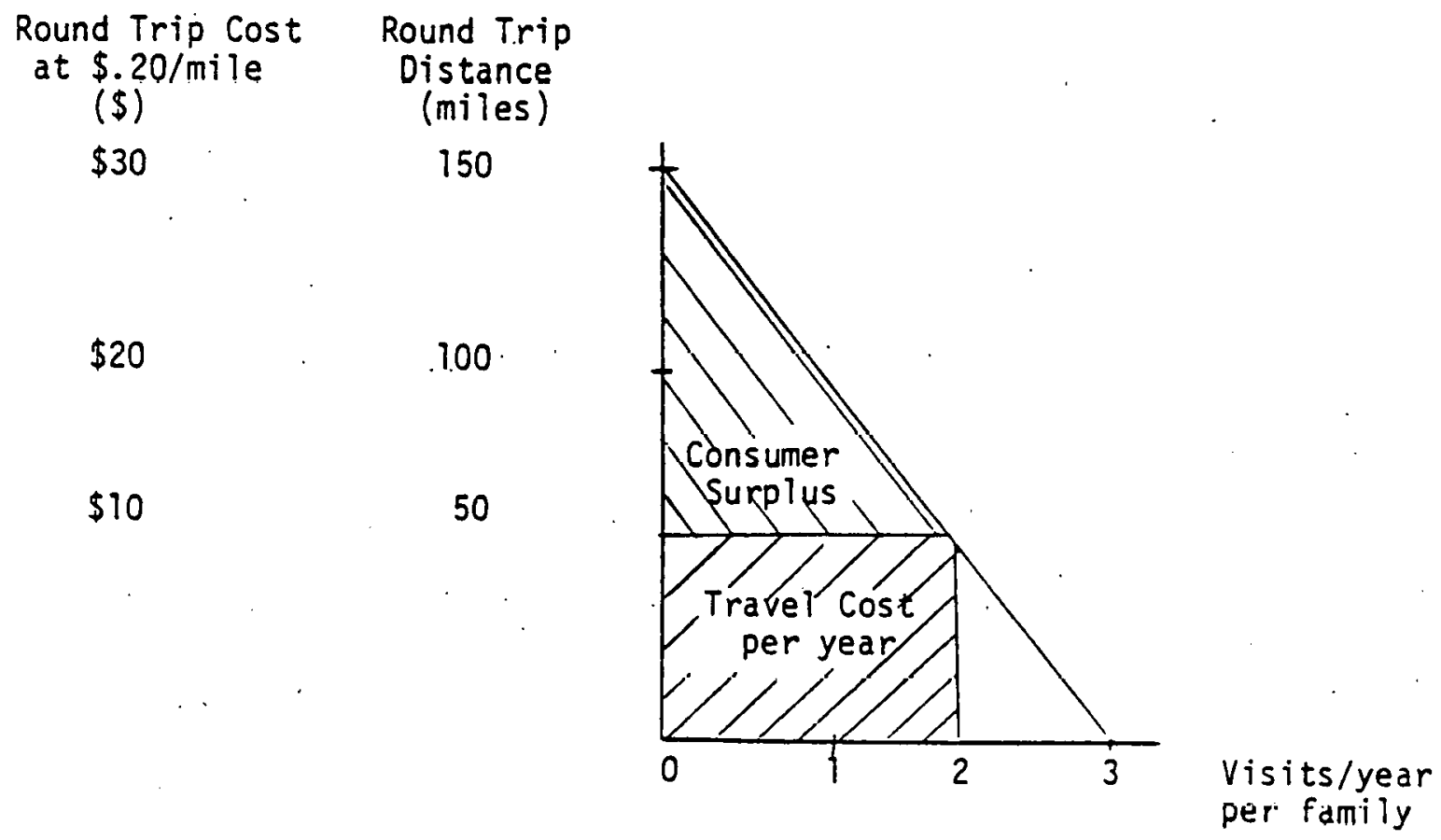


This household is assumed to live a round trip distance of 50 miles from the recreation site and thus, from the demand curve, yisits twice a year. Total travel costs per year are thus given by the lower shaded area of $(2$ visits $/$ year $) \times(50$ miles $) \times(\$ .20 /$ mile $)=\$ 20 /$ year. The remaining upper shaded area is then the consumer surplus, or willingness to pay net of travel costs. This upper, shaded area is the appropriate benefit measure for the recreation experience if one ignores other recreation expenditures and assumes no "scenic" benefits for traveling to the site. Studies of the value of fishing derived from published water-based recreation demand studies (most are part of the "furtive" literature which must go uncited) suggest that $\$ 10-\$ 20$ per fisherman day is an appropriate range for benefits. Thus, as a very rough order of magnitude indication of recreation loss for prohibiting fishing in a contaminated lake or stream, one could multiply this value by the number of fisherman days lost. However, a much preferred procedure would be to construct a site or region specific demand relationship for economic analysis.

An alternative to the travel-cost approach as outlined above is use of survey questionnaires. For example, Brown, Singh and Castle (1964) estimated the value of the Oregon salmon and steelhead fishery by-postulating an hypothetical increase in costs/day for fishermen to trace out a relationship similar to that shown in Figure 5.3. In calculating net benefits, adjusted for inflation, their results were consistent with a current value of $\$ 10-\$ 20$ per fisherman day as noted above.

b) Broader Ecosystem Effects

Valuing an uncontaminated or pristine environment clearly must go beyond valuing consumptive recreation alone (fishing, hunting, etc.). 
The recreation experience may be dramatically affected by the abundance of wildlife. Siting of a porcupine, pronghorn antelope, marmot, elk, or other animal by a recreator on a hike or merely by travelers on a highway has some value or benefit. Perhaps even more significant is the possibility of option demand -- demand by non-users for a pristine environment. Convincing evidence of option demand comes from the concern of, for example, New Yorkers over preservation of the Grand Canyon. Similarly, news articles concerning far away environmental catastrophes causes concern among environmentalists nationwide. One explanation for option demand is that even though an individual may not use a particular pristine area today, that individual may want to retain the option of using that area in the future and so be willing to pay for preservation.

Both types of effects noted above, subtle values associated with wildlife populations and option value are likely to be difficult or impossible to capture using a $\mathrm{Cl}$ awson-Hotelling methodology. However, recent research has suggested that valid values might be obtained through survey questionnaires wherein individuais are directly queried as to the value of environmental attributes. This approach was pioneered by Randall, et al. (1974), and has more recently been applied by Brookshire, et al. (1976). However, two new studies bear direct relevance to the problem of valuing ecosystem effects. First, Brookshire, Randall and Stoll (1980) have applied the survey technique specifically to valuing wildlife sitings and option value of wildlife preservation. Typical values from this research are as follows: For an encounter (siting) with elk, hunters were willing to pay about $\$ 44$ (consumptive use). To prevent a $50 \%$ reduction in duck and geese populations, non-hunters who used possible affected recreation areas were willing to 
each pay on the average $\$ 175$ per year (non-consumptive use). As a measure of option value, hunters, for example, were willing to pay $\$ 21$ annually today to improve odds of getting a license by $25 \%$ to hunt grizzly bear in Wyoming five years hence (no licenses are currently granted because grizzly are endangered). Note that the last measure, a quantification of option value, while useful for experimental purposes, in no way captures the broad ecosystem values which have been postulated. In any case, the study does suggest that preservation of wildlife populations has considerable value. Thus, toxic effects on wildlife populations could conceptually be valued through survey research.

However, one question has plagued such survey research: will people actually pay what they say they will pay (in a survey) for environmental preservation? A recent study by Brookshire, d'Arge, Schulze and Thayer (1980) has addressed this question by comparing the results of a suryey questionnaire for the value of air quality in the Los Angeles basin with a study of how property values are affected by air quality. Presumably, if people value air quality, they should be willing to pay more for homes in clean air areas. This study suggests that survey questionnaire values for clean air are quite close to the dollar premiums people pay for homes in clean air areas. This study, thus, lends considerable support to the survey approach. However, one must note that air quality is a particularly. well-defined environmental characteristic in the Los Angeles basin. Other environmental attributes may be considerably more difficult to quantify for survey analysis. 
Calculating the Benefits of Trace Element Control

a) Discounting

Our first problem in calculating benefits is the choice of discount rate. Economists justify use of a discount rate on both future benefits and costs -- weighting future economic values less than current economic yalues -- as follows: imagine that an individual fifty years from now is exposed to a toxic trace element which was disposed of improperly today. Further, let us assume that the future individual would accept a payment of $\$ 2,500$ as "fair" compensation for that exposure." If we, the current generation, wish to compensate that future individual, do we need to set aside $\$ 2,500$ ? Is the damage now the same as the damage fifty years hencl? The usual economic answer is negative. If we were to invest $\$ 558$ today in a bank account paying a $3 \%$ real rate of return (over inflation) we would have $\$ 2,500$ of real value in accumulated interest and principal fifty years hence to compensate the exposed future individual. Thus, the argument goes, a $3 \%$ discount rate would be appropriate on damage done to future-generations in making decisions today. For example, if proper disposal of our example toxic element were to cost more than $\$ 558$, benefitcost analysis would suggest not to bother, even though we will do $\$ 2,500$ worth of harm fifty years hence. Many would, of course, view such a decision as unethical. Page (1977), for example, argues that compensation is likely to be only hypothetical and not real,:making the whole discounting procedure meaningless on ethical grounds since actual compensation is not likely to be paid. Thus, serious ethical problems surround the choice of discount rate.

*For a discussion of ethics and discounting, see Chapter Two of A Study of the Ethical Foundations of Benefit-Cost Analysis Techniques, Ben-David, et al. (1979). 


\section{b) Aggregation}

Damages from trace element omissions will likely. accrue to a variety of non-homogeneous groups and individual with varying preferences over health effects, recreation and energy development. If all individuals in the affected region had homogeneous (identical) preferences, then the decision on the degree of trace element control, a public good, might be simplified. However, even if this were true, at least in the Southwest, the benefits of further energy development will likely accrue principally outside of the region, since most electric power will be exported. Thus, environmental costs will "inequitably" fall on local inhabitants. Traditional benefit-cost analysis ignores such potential inequities in aggregating benefits and costs across the entire nation regardless of the way in which they accrue. Thus, the aggregation problem can be viewed as a recasting in broader terms of the problems discussed above under the topic of ethics and valuing health risks.

Possible solutions to the problem of aggregating benefits and cost.s across diverse groups include, as suggested above, the reweighting of dollar benefits and costs according to alternative ethical systems, or a check for regional equity in terms of impacts and financing of energy development may be in order.

c) Economic Analysis in an Uncertain World

Given the uncertain nature of events which may lead to human exposures to trace elements or to recreation losses, a stochastic approach is needed which accounts for both costs of control for trace elements and for environmental monitoring to prevent possible exposures. A simple modeling framework is developed below to structure economic analysis.

Let $C$ denote cost of control for trace elements. For example, the 
greater the care and cost of disposal of fly ash, the less likely it will be that material will find its way into streams. Thus, the probability of contaminaticn of streams and lakes, $P$, becomes a decreasing function of that cost $P(C)$, so $d P / d C=P^{-}<0$. Let us further assume that the $\therefore=$ probability of potential human exposure, $\pi$ (given a release event such as a flash flood washing out a disposed fly ash pond), which could cause health damages, $D_{H}$, is reduced by the cost for monitoring, $M$, so we have $\Pi$ as a function of $M, \Pi(M)$, where $2 \Pi / \Pi M=\Pi^{\circ}<0$. However, given contamination, any reduction in the probability $I$ of health effects, $D_{H}$, linearly increases the probability $\left(1-\pi_{H}\right.$ ) of recreation damages $D_{R}$ since fishing and other recreation activities must be prohibited to prevent health effects. In other words, given a release event, we can only prevent health damages by prohibiting recreation. The total expected cost of trace element management can then be defined as:

$$
P(C)\left[\Pi(M) D_{H}+(1-\pi(M)) D_{R}\right]+(C+M)
$$

The first term is expected damages, equal to the probability of a release event $P$ times the expected damages which occur as a result of contamination. These damages can be shifted from health costs, $D_{H}$, to recreation damages, $D_{R}$, since a monitoring program would, for example, reduce odds, $\pi$, of health damages by prohibiting recreation activities such as fishing. The second term $(C+M)$ is the sum of control and monitoring costs. We wish to then develop a program for "optimal" trace element management which minimizes the sum of these costs with respect to both $C$ and $M$. First order conditions are then for $C$, control costs,

$$
\text { (a) }\left[\pi D_{H}+(1-\pi) D_{R}\right]=-\left(\frac{1}{P^{-}}\right)=\frac{d C}{-d P} \text {, }
$$


and for $M$, monitoring costs,

$$
\text { (b) } P\left(D_{H}-D_{R}\right)=-\left(\frac{l}{\Pi^{-}}\right)=\frac{d M}{-d \Pi} \text {. }
$$

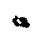

Condition (a) implies that the sum iof expected health and recreation damages if an event occurs should equal the marginat cost of decreasing the probability of release of trace elements through control and better disposal practices. Condition (b) implies that the expected difference between health damages (e.g., thuse which would occur if humans were exposed through an undetected contamination of fish by toxic trace elements) and recreation damages (e.g., the recreation value from fishing lost by a ban if contamination is detected) should equal the marginal monitoring cost of decreasing the probability of health damages. Note in this latter condition we, of course, assume that health damages are potentially greater than recreation damages $\left(D_{H}>D_{R}\right)$, so a monitoring program is worthwhile.

Reinterpreting our two conditions in benefit terms givas us the following conclusions: (1) the benefits of a toxic trace element control program are the resulting reduced health and recreation damages [which must equal marginal cost of control in (a)] and (2) the incremental benefits of a toxic trace element monitoring program are (in our example) the expected savings in substituting recreation losses for human health damages [which must equal the marginal cost of monitoring in (b)].

In conclusion, the uncertain nature of the tonic trace element llanagement problem provides an integrating framework for defining both benefits and costs. However, the implementation of the methodology outlined in this chapter is only partly straightforward. Any calculations of benefits and costs, wherein human health and long time spans are involved, should likely be carried out with sensitivity to ethical and distributive as well as economic issues. 
Notes and References for Chapter 5

Ben-David, S.; Kneese, A.; Schulze, W.; A Study of Ethical Issues in. Benefit-Cost Analysis, study funded by the Ethics and Values in Science and Technology Program of the National Science Foundation (1979).

Bentham, J.; An Introduction to the Principles of Morals and Legisiation (1789).

Boyet, W. E.; Tolley, G. S.; "Recreation Projection Based on Demand Analys is," Journal of Farm Economics, Vol. 48, No. 4 (November 1966) pp. 984-1007.

Brookshire, D.; Ives, B.; Schulze, W.; "The Valuation of Aesthetic Preferences," Journal of Environmental Economics and Management, Vol. 3 (1976).

Brookshire, D.; d'Arge, R.; Schulze, W.; Thayer, M.; "Experiments in Valuing Public Goods," Advances in Mieroeconomic Theory, edited by V. Kerry Smith (forthcoming, 1980).

Brookshire, D.; Randall, A.; Stoll, J.; "Valuing Increments and Decrements in Natural Resource Service Flows," American Journal of Agricultural Economics, (forthcoming, 1980).

Brown, G.; Singh, A.; Castle, E.; Economic Evaluation of the Oregon. Salmon and Steelhead Sport Fishery, Technical Bulletin $\# 78$, Agricultural Experiment Station, Oregon State University (September 1974).

Cessario, F. J.; Knetsch, J. L.; "Time Bias in Recreation Benefit Estimates," Water Resources Research, Vol. 6, No. 4 (August. 1970) pp. 700-704.

Clawson, M.; Methods of Measuring the Demand for the Value of Outdoor Recreation, Reprint 10, Washington, D. C.; Resources for the Future, Inc. (1959).

Clawson, M.; Knetsch, J. L.; Economics of Outdoor Recreation, Baltimore, Maryland; The Johns Hopkins Press (1966) pp. 36-40.

Crocker, T.; Schulze, W.; Ben-David, S.; Kneese, A.; Experiments in the Economics of Air Pollution Epidemiology, EPA, (1978).

Grubb, H. W.; Goodwin, J. R.; Economic Evaluation of Water Oriented Recreation in Preliminary Texas Water Plan, Report 84, Texas Water Development Board. (September 1968). 
Johnston, W.; Pankey, V.; "Some Considerations Affecting Empirical Studies -of Recreational Use," American Journal of Agricultural Economics, Vol. 50, No. 5, (December 1968) pp. 1739-1744.

Kant, I.; Fundamental Principles of the Metaphysics of Morals, (1785).

Knetsch, J. L.; "Economics of Including Recreation as a Purpose of Eastern Water Projects," Journal of Farm Economics, Vol. 46, No. 5 (December 1965) pp. 1148-1157.

Knetsch, J. L.; "Outdoor Recreation Demand and Benefits," Land Economics, Vo1. 39, No. 4 (November 1963) pp. 387-96.

Lave, L.; Seskin, E. P.; "Air Pollution and Human Health," Science 109, (August 1970) pp. 723-732.

Mill, J.; Utilitarianism (1863).

Mishan, E.; Introduction to Cost Benefit Analysis, New York; Praegar (1971).

Nozick, R.; Anarchy, State, and Utopia, New York; Basic Books (1974).

Page, T.; Conservation and Economic Efficiency, Baltimore; John Hopkins (1977).

Rand, Ayn; The Virtue of Selfishness, New York; American Library (1964).

Randa 11, A.; Ives, B.; Eastman, E.; "Bidding Games for Valuation of Aesthetic Environmental Improvements," Journal of Environmental Economics and Management. Vol. 1 (1974).

Rawis, John; A Theory of Justice, Cambridge; Belknap Press (1971).

Rice, Dorothy; Estimating the Cost of IIlness, U. S. Department of Health, Education and Welfare, Public Health Service, Home Economics Serfes No. 6 (May 1966).

Smith, Robert S.; "The Feasibility of An 'Inquiry Tax' Approach to Occupational Safety," Law and Contemporary Problems (Summer-Autumn, 1974).

Starr, D.; "Social Benefit vs. Technological Risk," Science, Vol. $165^{\circ}$ (1969).

Thaler, R.; Rosen, S.; "The Value of Saving a Life: Evidence from the Labor Market," Household Production and Consumption, N. E. Terleckyj, ed. , New York; Columbia University Press (1976). 
Chapter 6

Federal Legislation and Regulations

Affecting Trace Element Emissions

Previous chapters of this report have discussed atmospheric, aquatic, and landborne emissions of trace elements by coal-fired power stations. In this chapter, the $i$ slative acts and administrative regulations that affect or could affect inese emissions are discussed. In fact, there are a dozen or more laws tiat have potential for regulation of trace element emissions, but we wili consider only five of these in detail:

1. The Clean Air Act, especially the 1977 amendments to this act;

2. The Federal Water Pollution Control Act, especially the 1977 amendments to this act;

3. The Safe Drinking Water Act of 1974;

4. The Resource Conseryation and Recovery Act of 1976;

5. The National Environmental Policy Act of 1969.

The first of these deals with atmospheric emissions; the next two concern waterborne wastes; and the fourth involves solid wastes (although it also deals with waterborne wastes if solidsllare discharged as an aqueous sludge). The last act might affect any kind of environmentai emissions whether to the atmosphere, surface water, or groundwater.

\section{The Clean Air Act}

The section of the Clean Air Act that is of interest is Section 110 of the 1970 act as amended in 1977; this section deals with hazardous air pollutants. However, before discussing this section, it is worthwhile to mention the main provisions of the Clean Air Act. Easton and 
O'Donnell [ 1 ] summarized the Act and amendments to it in the following paragraphs:

"The Clean Air Act Amendments of 1970 introduced the philosophical premise that the most practical and efficient means of air pollution control would result from a blend of two complimentary notions. National ambient air quality standards, designed to protect public heal th and welfare, were to be established at 'threshold levels' below which no adverse effects would occur. Emission standards, based on control technology, would be imposed to bring pollution concentrations below ambient standards and keep them there.

The Clean Nir Act Amendments of 1977 retain this fundamental approach to air pollution control, not withstanding provisions requiring thorough review of both ambient and emission standards, as well as alternative pollution control strategies. The new law also retains the basic mechanism through which this approach would be implemented: the state implementation plan.

Under the 1970 amendments, implementation plans were to include such emission limitations and other measures as might be necessary to attain and maintain primary ambient air quality standards by a certain date. That scenario is retained in all essential respects in the 1977 amendments, though attainment deadlines have been pushed back and appropriate control measures more fully detailed.

For those areas which have not attained ambient standards (so-called "nonattainment areas") states must have an approved implementation plan revision by July 1, 1979, which provides for attainment of primary standards by December. 37, 1982. This requirement is a precondition for construction or modification of major emission sources in nonattainment areas after June 30, 1979.

If despite implementation of all 'reasonably ayailable. measures', a state cannot attain primary standards for carbon monoxide or photochemical oxidants in timely fashion, it must submit a second plan revision by December 31, 1982 which provides for attainment by December 31, 1987. All plan revisions must. prior to attainment. provide for 'reasonable further progress' toward attainment in terms of annual incremental reductions in emissions.

For those areas which are cleaner than required by ambient standards, implementation plans must include an elaborate program to prevent the significant deterioration of air quality. All such 'nondegradation' areas must be designated Class I, II, or III, depending upon the degree of deterioration that is to be allowed, and limits are assigned to pollution concentrations for each classification. 
Congress specified which of these areas must be protected by the most stringent Class I designation. All others would be initially designated Class II with states generally free to redesignate them as Class I or III. Congress also specified the maximum allowable increases in concentrations of sulfur dioxide and particulate for each classification and gave EPA two years to come up with comparable formulas for hydrocarbons, carbon monoxide, photochemical oxidants, and nitrogen oxides.

In both 'nonattainment' and 'nondegradation' areas, major stationary sources may be constructed only. by permit and must, at the very least, meet new source performance standards presented by the law. As a general rule, these will require application of the 'best technological system of continuous emission reduction.'

There, in a nutshel1, is the Clean Air Act, as amended in 1977 and as enacted in 1970."

It might be emphasized that six pollutant classifications have been the subject of ambient standards by law or by EPA regulation. The six are: particulate matter, sulfur dioxide, hydrocarbons, nitrogen dioxide, carbon monoxide, and photochemical oxidants. Although this report emphasizes emissions of trace elements, coalfired power stations are a major source of sulfur oxides, particulates, and nitrogen oxides. Indeed, the 1977 Amendments to the Clean Air Act set forth some specific regulations for sulfur oxide emissions from coal-fired power plants. The 1977 amendments required that specific percentage reductions in sulfur oxide emissions be made (as compared to emissions from uncontrolled burning); also, it was required that EPA set a "ceiling" on $\mathrm{SO}_{2}$ emissions above which no coal-fired power plant would be allowed to go. In regulations proposed at the end of 1978, EPA set $\mathrm{SO}_{2}$ percent reduction requirements at $85 \%$ and the $\mathrm{SO}_{2}$ emission "ceiling" at 1.2 pounds ner million Btu utilized (for discussion see Resources, January-February 1979 [2]). 
Sawyer [3] has a detailed discussion of $\mathrm{SO}_{2}, \mathrm{NO}_{x}$, and particulate emissions from coal-fired power plants. Although this report has mentioned sulfur oxide and nitrogen oxide emissions only rarely, these two pollutants will be discussed briefly in the concluding chapter. In fact, it will be indicated that $\mathrm{SO}_{x}$ and $\mathrm{NO}_{x}$ emissions are probably the major environmental problem of coal-fired power plants.

Trace elements are covered by Section 110 of the Clean Air Act; this section gives EPA power to set emission standards for hazardous air pollutants. Under the 1977 amendments to the Act, EPA is empowered to prescribe emission control equipment, designs, and/or work practices if it is not feasible to enforce an emission standard. Under Section 110 EPA has issued regulations for four hazardous air pollutants--asbestos, beryllium, mercury, and vinyl chloride. Asbestos and vinyl chloride are not emitted by coal-fired power plants but both beryllium and mercury are emitted. The EPA regulations for beryllium specifically apply to coalfired power plants and such plants must meet either the beryllium emission standard or ambient standard. The beryllium emission standard provides that no more than 10 grams shall be emitted over a 24 hour period. The ambient standard for beryllium provides that in the immediate vicinty of the plant ambient air shall measure no more than .01 micrograms per cubic meter of beryllium when this average is taken over a 30 day period.

Al though mercury is regulated as a hazardous air pollutant, there are apparently no regulations for mercury emissions of coal-fired power plants. EPA regulations on mercury apply to plants other than power stations, e.g., sludge incineration plants.

It is also worth mentioning that unofficial discussions have 
indicated EPA is working on issuing regulations for two other hazardous air pollutants--arsenic and cadmium. Both of these are emitted by coal-fired power plants. But the date at which cadmium and arsenic regulations might be issued is uncertain; also, it is unclear whether such regulations will apply to coal-fired power stations [4].

A final note on regulation of trace element emissions is that in 1978 EPA proposed an ambient air standard for lead. The proposed standard is 1.5 micrograms of lead per cubic meter of air averaged over a 30 day period. States are to develof plans which indicate how they will attain maintenance of the lead standard by 1982. Consequently, lead emissions by coal-fired power stations may come under additional state regulation. A note on the sources of lead may be of interest:

"In 1975, about 142 thousand metric tons of lead were emitted nationwide. Combustion of gasoline accounted for 90 percent of those emissions; combustion of crankcase oil, solid waste, oil, and coal accounted for an additional five percent; and the remaining five percent came from 19 industrial categories."[5]

In summary, beryllium is the only trace element in coal-fired power plant emissions presently regulated. In the future, power plant emissions of lead, cadmium, arsenic, and mercury could conceivably also come under federal and state regulations. Although the tentative calculations in Chapter 2 indicated that atmospheric emissions of trace -lements would probably not cause major problems, it is still likely that some review of regulation of trace element emissions would be desirable. It might be particularly important to begin to set standards for power plant emissions of mercury, selenium and arsenic. 
The Federal Water Pollution Control Act

Much of the potential water contamination from trace elements in coal-fired power plant effluents involves groundwater contamination. Another section of this report has dealt with the mechanisms through which trace elements in bottom ash and disposed fly ash may contaminate groundwater. If, however, power plant effluents are discharged to streams or creeks in the Southwest, trace elements in those may be subject to federal and state regulation under the Federal Water Pollution Control Act as (FWPCA) amended in 1977.

Unider FWPCA of 1972 all dischargers of regulated water pollutants were to install "best practicable control technology" (BPT) by 1977. In point of fact many dischargers had not installed such equipment (as specified by EPA); municipal wastewater plants were especially notorious offenders. Under the 1977 amendments, the deadline for installation of BPT was extended to 1979 for facilities which began construction of adequate treatment by the end of 1977. There were also other deadline extensions for municipalities: More importantly for our purposes, the 1977 amendments divide pollutants in to three categories--conventional pollutants (mainily suspended solids and biochemical oxygen demands (BUU)), toxic pollutants (including a list of trace metals and their compounds), and unconventional pollutants. Main interest here is on toxic pollutants.

The FWPCA of 1972 empowered EPA to set effluent standards for toxic pollutants. ' In 1973, EPA published a list of standards for nine toxics but at a hearing it was decided that EPA could not justify the standards. In 1977, EPA finally set effluent standards for a list of six toxics. But the key event was a suit brought against 
EPA by environmental groups (National Resources Defense Council, et al vs. Train); the court settlement agreement in this suit requires, among other things that EPA develop standards for 65 toxic pollutants. Congress incorporated the list of 65 toxics into the 1977 amendments and required that industries discharging these install "best available technology" by 1984; or if EPA sets a toxic standard (expected in many cases), dischargers of the toxics would have three years to comply with the standards.

The list of 65 toxic substances includes the following:

-- arsenic and compounds

-- beryllium and compounds

-- cadmium and compounds

-- chromium and compounds

-- copper and compounds

-- lead and compounds

-- mercury and compounds

-- nickel and compounds

-- selenium and compounds

-- zinc and compounds

In sumary, any coal-fired power plant which discharges to streams or creeks of the Southwest and whose discharge contains any of the preceding metals will have to install "best available technology" and/or meet specific effluent standards, depending on future EPA regulations for toxic effluents. It is not clear whether these requirements would apply to power plants which have ash ponds normally cischarging to groundwater but with the possibility of dam breaks (such as hypothesized in 
Chapter 3). Because catastrophic events such as breaking of ash pond dikes are a major threat future regulations may need to deai more clearly with this question.

Regulation of groundwater contamination does not play the important part that regulation of surface water contamination has played under FWPCA. Indeed the Senate Committee on Public Works in its report on the 1972 FWPCA stated:

"Several bills pending before the Committee provided authority to establish federally approved standards for groundwaters which permeate rock, soil, and other subsurface formations. Because the jurisdictions regarding groundwaters is so complex and varied from State to State, the Committee did not adopt this recommendation.... Groundwater pollution is not as serious a national problem at present as is surface water pollution, but groundwater availability and quality is deteriorating. "[6]

However, FWPCA does include important provisions for the management of groundwater quality:

-- States develop plans for waste-management and water pollution control under the Act; the plans are to include processes to control groundwater quality and the agency must be empowered to enforce such plans.

-- State plans must include processes to control land disposal of pollutants that may impact groundwater quality.

Under these provisions of FWPCA, it is clear that states can regulate trace metal contamination of groundwater resulting from seepage from ash ponds and/or scrubber sludge ponds. Apparently, however, most emphasis in state plans is on protection of surface water quality. Resource Conservation and Recovery Act (RCRA)

RCRA, enacted in 1976, is intended to deal with the increasingly important problem of land disposal of wastes, especially wastes that 
are toxic to human beings. In previous sections, it has been noted

that toxic materials disposed on land may seep into groundwater, wash

into streams, or, possibly, become airborne. An EPA publication.states:

"Virtually every day, the media carries a story on a dangerous situation resulting from improper disposal of hazardous waste. The tragedy at Love Canal in New York State is but one recent example. EPA has compiled over 400 case studies of the harmful consequences of inadequate hazardous waste management. These cases include incidents of surface and groundwater contamination, direct contact poisoning, various forms of air pollution, and damage from fires and explosion... The Resource Conservation and Recovery Act of 1976 was passed to address these problems." [7]

As summarized by Barrett [8], the main provisions of RCRA are that

EPA is given authority to:

"- develop and promulgate criteria for identifying the characteristics of hazardous waste, and for listing hazardous waste;

- promulgate standards applicable to generators of hazardous waste as necessary to protect human health and the environment that require recordkeeping practices, labeling practices, use of appropriate containers, furnishing information on chemical composition, use of a manifest system, and submission of reports;

- promulgate regulations applicable to owners and operators of facilities for the treatment, storage, or disposal of hazardous waste that include requirements for recordkeeping, reporting, monitoring, and inspection and compliance with the manifest system; treatment, storage, and disposal of wastes by satisfactory methods, techniques, and practices; location, design, and construction; contingency plans; maintenance and operation; and compliance with requirements for permits;

- promulgate regulations requiring each person owning or operating a facility for the treatment, storage, or disposal of identified or listed hazardous wastes to have a permit;

- promulgate guidelines to assist states in the development of state hazardous waste programs."

In December 1978 EPA set forth a set of proposed guidelines and regulations under RCRA. Among these the most, relevant for this report 
are the paragraphs dealing with utility waste (i.e., bottom ash, recovered

fly ash, and scrubber sludge). In the reference cited above, EPA stated:

"... certain very large volume wastes will be hazardous under Subpart A standards and thus will come within the purview of the Subtitle $C$ regulatory scheme. These wastes are cement $k i$ in dust, utility waste (fly ash, bottom ash, and scrubber sludge), phosphate mining and processing waste, uranium and other mining waste, and gas and oil drilling muds and production brines. ... The limited information the Agency has indicates that such wastes occur in very large volumes, that the potential hazards posed by the waste are relatively low, and that the waste generally is not amenable to the control techniques [listed elsewhere]. The Agency is calling such high-volume hazardous waste 'special waste.' and is proposing to regulate it with special standards."

EPA then indicates that utility waste will be exempted from RCRA regulations concerning storage, treatment, and disposal al though special regulations for utility wastes may be issued at some date in the future. Utility wastes are, however, subject to certain regulations involving monitoring of waste composition, collection of surface water runoff, maintenance of records, and preparation of reports.

In summary, utility wastes--bottom ash, recovered fly ash, and scrubber siludge--are presently subject to only minimal regulation under RCRA. This situation could, of course, change in the future if EPA issues additional regulations for utility waste. But our research has indicated that ash disposal from power plants poses a potentially threatening situation. 'The extent of this threat is unclear, but it is likely that present regulations are not sufficient to protect the public and the environment. Our unofficial information is that EPA is reviewing ash disposal regulations, such review is highly desirable.

Other Legislation

Two other acts that should be mentioned are the Safe Drinking Water Act of 1974 and the National Environmental Policy Act (NEPA) of 1969. 
Safe Drinking Water Act:

The basic provisions of this act enable EPA to set standards for drinking water. In addition, the act provides for some regulation by EPA and by states of injection of wastewater (and aqueous sludge) in underground cavities, wells, etc. Such injections could contaminate area groundwater which, in some places, is an important source of. drinking water. Many states, however, have had no major problems with. underground injections. Eventually, regulations concerning underground injections may cover pits, ponds, and lagoons; conceivably, such regulations could extend to ash ponds at coal-fired power stations. But, in the Southwest, there is apparently no current regulation of this type under the Safe Drinking Water Act.

National Environmental Policy Act (NEPA) of 1969:

As is well known, NEPA is the act that requires environmental impact statements for major actions of federal agencies. Among aspects of the enyironment that may be impacted are the atmosphere, groundwater, and surface water. For example, with respect to groundwater, Ballentine [9] points out:

"Even though NEPA does not affect groundwater quality directly, the Act does require that, when applicable, groundwater quality, among other environmental concerns, should be considered in any environmental impact statement that would be prepared. These impacts would then be subject to review by appropriate agencies, and must be considered before the final project design."

Thus, new coal-fired power plants, under most circumstances, will be required to make statements about possible effects on groundwater, surface water, and the atmosphere. Therefore, indirectly, NEPA may affect emissions to the environment. 
Conclusions

Probably the most important finding of this chapter involves the need for review of regulations relating to ash disposal. Protection of surface water and groundwater from trace elements in disposed ash is quite likely to be inadequate at present. Some review of regulation involving trace element atmospheric emissions would also seem desirable al though regulations concerning ash disposal seem to ceserve more emphasis. 
Notes and References for Chapter 6

[1] Easton, E. B. and O'Donne 11, F. J., "The Clean Air Act Amendments of 1977." Journal of the Air Pollution Control Association, October 1977.

[2] Resources, January - February 1979, (newsletter of Resources for the Future, Washington, D.C.).

[3] Sawyer, James W.; Harrington, Winston; and Abbey, David, The Electric Power and Synthetic Fuels Industries in the Southwest: Production and Environmental Control Technologies, (paperbound report prepared by Resources for the Future, Washington, D.C.) August 1977.

[4] Personnel at the New Mexico Environmental Improvement Division. were extremely. helpful in providing information on regulation of hazardous air pollutants. Any errors in the above description are, of course, ours.

[5] "EPA Proposes Ambient Air Quality Standard for Airborne Lead," Journal of the Air Pollution Control Association, February 1978.

[6] U. S. Senate Committee on Public Works, Report on the Federal Water Pollution Control Act, Senate Report No. 92-414, 1972.

[7] U. S. Environmental Protection Agency, Hazardous Wastes: Proposed Guideliries and Regulations and Proposal on Identification and Listing, reprinted from Federal Register, December 18, 1978.

[8] Barrett, Bruce, "Controlling the Entrance of Toxic Pollutants into U. S. Waters," Environmental Science and Technology, February 1978.

[9] Ballantine, R. K., "Overview of Federal Groundwater Protection Legislation Aids Environmentalists," Water and Sewage Works, Aprit 1978. 


\section{Chapter 7}

Conclusions

In this report, an attempt has been made to present a framework for benefit-cost analysis of trace elements. It has been noted that there are many pitfalls in trying to do such an analysis: it is difficult to specify trace element atmospheric emission rates with precision. Rates of trace element seepage to groundwater are largely unknown. Precise dose-response relationships for trace elements are subject to debate; and so forth. But the basic benefit-cost framework outlined in this report is probably sufficient to conduct an analysis. The more important question, however, is whether trace elements from coal-fired power plants are presently causing damage or are likely to cause future damages.

In trying to answer this question, some rough calculations of likely impacts of trace element atmospheric emissions were made in Chapter 2. Probably the major trace element in atmospheric emissions likely to cause damage is mercury, and Chapter 2 calculations showed that power plant mercury emissions would cause an increase of mercury in fish tissue of about..1 ppm. This is below the F.D.A. threshold for toxicity in edible fish, and the preliminary conclusion was that atmospheric emissions of trace elements from power plants in the Southwest may not cause significant problems even under fairly drastic assumptions.

But this conclusion must be viewed as tentative, and may not prove correct:

(1) The calculation is for a one-year period. In fact, mercury may build up in area lakes over several years, and concentrations in fish, 
via bioaccumulation, may begin to exceed threshold levels of toxicity. The long run potential for mercury contamination in fish tissue is difficult to assess.

(2) Accumulation of trace elements in mountainous regions of the Southwest might become a problem (particularly important might be trace element accumulations in the southern Rocky Mountains). Also, the potential for other localized "hot spots" (areas of interise trace element fall-out) should not be ignored.

(3) In light of these possible problems, monitoring for possible trace element build-up would be a prudent course of action. Locations for such monitoring might include stations in the southern Rocky Mountains and in Navajo Reservoir on the San Juan River.

It is very difficult to reach conclusions with respect to disposal of bottom ash and fiy ash. Some seepage of trace elements from ash ponds to groundwater is likely to occur, but the extent of contamination is uncertain. In Chapter 3, two calculations of the extent of possible surface water contamination were made. The first calculation referred to a case in which all ash disposed in a one year period from a 2000. Mw station reached the San Juan River. In this case, mercury contamination of fish tissue will probably exceed acceptable leveis. In another case, calculations were made on the assumption that ash ponds holding a longterm accumlation of disposed ash experienced dam failure and spilled to the San Juan River. In this case, tolerance levels for mercury, arsenic and selenium are all. exceeded, and trace element damages are almost certain 
to occur. But it must be remembered that these calculations are for adverse cases; indeed, the second calculation refers to a near catastrophic event. To place the problem of trace element contamination from disposed ash in a different perspective, it was noted, first, that much power plant ash will not be flushed to rivers; most water in power plant ash ponds might be recycled, evapotranspired, or seeped to the ground. Second, the real problem with trace elements in ash ponds could actually be groundwater contamination rather than river contamination. But groundwater contamination might not be severe because areas most likely to be impacted have large distances from topsoil to the water table. Moreoyer, in many areas the water table is already high in mineral content.

The conclusion that is drawn from these considerations is that probable damages from disposed ash remain a question mark. "Bad case" calculations indicate some important potential damage, but other considerations may offset this conclusion. Because of these uncertainties, it is recomended that additional research be conducted on the possibility of damages from trace elements in disposed ash.

Before concluding, other evidence of damage from trace elements may be reviewed. First, it may be pointed out that previous chapters indicate that coal-fired power plants are one of the major sources of atmospheric trace elements. The other major sources are the ferrous and non-ferrous metals industries (iron and steel, copper, lead, zinc). If, then, indus- trial emissions of trace elements are causing problems in the U.S., it is very probable that coal-fired power plants are a major contributor to the problem. However, this answer begs the issue because it does not state whether there is a real problem in the first instance. 
Another consideration with respect to damages from trace elements is the importance of distinguishing between acute and chronic effects of trace elements. "Acute" effects refer to cases in which trace elements have directly caused death or illness due to intake in toxic amounts (e.g., exposure of copper smelter workers to fugitive emissions of arsenic oxides that cause vomiting, burning sensations, etc.). "Chronic" effects inyolve cases in which humans, animals, or plants have been exposed to trace elements over extended periods of time and, as a result, become $i l l$ or die. As an example of chronic effects, one may cite liver and/or kidney cancers that might be associated with inhalation or inqestion of cadmium. Chronic effects are more difficult to trace to a source than are acute effects because they have a variety of possible explanations.

A list of known incidents of acute effects from industrial sources includes:

-- The death from molybdenosis of a number of cattle in North Dakota in 1968. The cause of those deaths was the emission of molybdenum from burning of a uraniferrous lignite coal. This lignite was being ashed in kilns in order to upgrade the uranium content for commercial $U_{3} \mathrm{O}_{8}$ production. The lignite in question was particularly rich in trace elements including molybdenum. (For a complete discussion, see [1]).

-- Arsenic poisoning of bees and other lifeforms occurred in Czechoslovakia. Lim [2] states:

". arsenic poisoning in the area around a-coalfired power plant in Czechoslovakia was investigated by Bencko and others at the Charles University in. 
Prague. They found that children living in the vicinity of the power plant suffered from hearing damage and had very high concentrations of arsenic in their hair. The survey was prompted by the extensive death of bees due to arsenic poisoning which occurred within a $30 \mathrm{~km}$ radius of the plant. Domestic animals were also poisoned and the surrounding pastures were found to be contaminated. Drinking and surface waters in the area also contained unusually high levels of arsenic compared to water in uncontaminated areas. The source of contamination was thought to be a power plant which was emitting about one ton per day of arsenic from burning coal containing a very high level of 900 to $1500 \mathrm{ppm}$ arsenic. . ."

-- Cases of acute effects of trace elements also include lead poisoning among children living close to a copperlead smelter in El Paso, Texas and at least two cases of vanadium poisoning of workers doing maintenance on oilfired boilers in power plants [3]. There are, of course, other well-known cases of trace element poisoning including outbreaks in Iran and Japan attributable to trace elements in agricultural pesticides and fungicides.

In addition to this list of acute effects from trace elements, two pieces of evidence involving concern with possible effects may be added:

-- In August, 1979, the large Four Corners Power Plant near Farmington, New Mexico was directed to reduce its flow of ash pond water that now goes to the San Juan River in New Mexico. Present outflow is 3 million gallons per day but, under EPA order, must be reduced to one-half million. gallon per day. A newspaper article stated [4]:

"The pond water, which appears clean, contains boron, flouride, dissolved solids and sulphates. . ." 
-- The Electric Power Research Institute (EPRI), the electric utility industry's research arm, has shown great interest in EPA regulation of disposal of the industry's solid waste.

The EPRI Journal [5] recently stated:

"One major question the utility industry faces is which power plant wastes will be classified as hazardous under procedures proposed by the Environmental Protection Agency on December 18, 1978, pursuant to the Resource Recovery and Conservation Act. An EPRI data study published in September, 1978 indicated that ash, scrubber sludge, metal cleaning wastes, boiler blow down, and several other. power plant wastes might approach or exceed certain of the draft EPA limits. .."

The article goes on to mention 10 separate research projects presently funded by EPRI that deal with disposal of electric utility aqueous-solid wastes.

Neither of these two pieces indicate that damage is actually being done by trace elements in power plant wastes.

Perhaps the real issue of trace element effects involves longlived, chronic impacts rather than short-term, acute outbreaks. A continuous build-up of trace metals in soil, plants, animals and humans is, perhaps more threatening than the somewhat isolated acute outbreaks cited above. With respect to the importance of chronic effects, there is little hard data. But the whole issue was summarized in a recent study in North Dakota. This study estimated and projected power plant trace element emissions, atmospheric dispersion, and soil disposition. The report concluded [6]: 
"On the basis of response levels found in the literature, the projected depositions (of trace elements) on environmental receptors calculated in this phase of research are not expected to cause adverse effects on ecosystems during the short-term period of one year. However, questions still remain relative to the potential long-term effects of trace element emissions in the study area. These questions become of greater significance with a projected increase in coal utilization in the study area. ."

An identical statement could be made about the importance of the problem in the Southwest. We know of no case of acute effects of trace elements from power plants in the Southwest. But the question of chronic, long-term effects is a real issue, especially "with a projected increase in coal utilization" in the Southwest as in North Dakota.

Another area touched upon in this report involves the nature of federal legislation and regulation of trace elements from coal-fired power plants. It was suggested that regulation of trace element atmospheric emissions of mercury, selenium, and arsenic might need review. At present, only power plant atmospheric emissions of beryllium are regulated. Although we do not foresee extensive damage from trace element atmospheric emissions around power plants in the Soulhwest, some review of standards may be desirable. More importantly, we believe there is a need for review of regulations concerning power plant ash disposal. Our tentative calculations show more potential of trace element damage from this source than from atmospheric trace element emissions. Regulation of ash disposal is presently in its infancy, and additional research on this problem might help in preparing more adequate regulations.

Another issue that needs mentioning involves emission of sulfur and nitrogen oxides from power plants. Emissions of $\mathrm{SO}_{x}$ and $\mathrm{NO}_{x}$ become 
transformed in the atmosphere to sulfates, nitrates, and other compounds; later transformations, especially during storms, involve sulfuric acid and nitric acid complexes. The topic of acid rain in the Southwest has not been fully explored. Acid rain and/or acid snow-out may be especially important at higher elevations, such as in the southern Rocky Mountains. The research for this report did not directly touch the problem of acid precipitation, but as research proceeded views of the project team began to be more concerned with acid precipitation. We believe that acid rainout and snow-out are likely to cause more damage in the Southwest than trace elements.

A final topic involves environmental emissions of synthetic fuel plants (both coal gasification and coal liquifaction plants). This topic was not researched for this report, but it is likely that some of these plants will be constructed in the Southwest during the next 20 years. Coal liquifcation and/or coal gasification plants would have atmospheric and aqueous discharges of trace elements. Moreover, sulfur oxide complexes would aiso be emitted. Future research on environmental problems of coalfired power plants should be extended to cover the environmental problems of synthetic fuel plants in the Southwest.

The major conclusions of this report may be summarized in the following four points:

1. It is probable that atmospheric emissions of trace elements from Southwestern coal-fired power plants will not cause major problems over the next 20 years. But monitoring for trace element build-up (especially mercury, selenium, and arsenic) in the mountains of southern Colorado, Navajo Reservoir, and other local "hot spots" would be an important and desirable step. 
2. It appears that damage from trace elements in disposed ash is more likely than damage from atmospheric trace element emissions. But whether damage from disposed ash will actually occur is highly uncertain. We recommend that additional research be conducted on the entire range of issues surrounding ash disposal.

3. In the area of legislation and regulation, there may be some need for review of regulations concerning trace element atmospheric emissions. Our preliminary view is that present regulation of ash disposal is very likely to need revision and extension.

4. Future research on the environmental problems of coal-fired power plants should place emphasis on atmospheric emissions of sulfur and nitrogen oxides; consequent problems of acid precipitation in the Southwest also need exploration. Environmental research on coal-fired power plants does not need to exclude other problems. But issues surrounding sulfur emissions, nitrogen emissions, sulfate transformations, and acid precipitation appear to merit major emphasis.

Also, future research on environmental problems related to coal conversion in the western states should include consideration of synthetic fuel plants. Whether these plants will cause significant problems with sulfur and/or trace element emissions is a topic that merits some future exploration.

Perhaps the most important aspect of the preceding list of conclusions is that more questions are raised than are answered. As work on the subject proceeded, it became apparent that an important task was to point future 
THIS PAGE

\section{WAS INTENTIONALLY LEFT BLANK}




\section{Notes and References for Chapter 7}

[1] Christiansnn, G. and Jacobson, G., "Report on Molybdenosis in Farm Animals and Its Relationship to a Uraniferous Lignite Ashing Plant," North Dakota State Department of Health, 1969.

[2] Lim, M. Y., Trace Elements from Coal Combustion -- Atmospheric Emissions, IEA Coal Research, London, England, May 1979.

[3] Cases of vanadium poisoning of oil-fired power plant maintenance workers were mentioned to us by Dr. Suzanne Weissmann, Lovelace Biomedical and Environmental Research Institute, Albuquerque, New Mexico.

[4] Albuquerque Journal, August 4, 1979.

[5] EPRI Journal (magazine of the Electric Power Research Institute), June 1979.

[6] Miller, J.,Christianson, G., Schock, M., and Morrison, W., Trace Element Effects of Energy Conversion Facilities (A Phase One Final Report to the Odd West Regional Comission), Division of Environmental Engineering, North Dalota State Department of Health, November 1977. 